Cochrane Database of Systematic Reviews

\title{
St John's wort for major depression (Review)
}

Linde K, Berner MM, Kriston L

Linde K, Berner MM, Kriston L.

St John's wort for major depression.

Cochrane Database of Systematic Reviews 2008, Issue 4. Art. No.: CD000448.

DOI: 10.1002/14651858.CD000448.pub3.

www.cochranelibrary.com 
TABLE OF CONTENTS

HEADER

ABSTRACT

PLAIN LANGUAGE SUMMARY

BACKGROUND

OBJECTIVES

METHODS

RESULTS

Figure 1.

Figure 2.

Figure 3.

Figure 4.

Figure 5.

Figure 6.

Figure 7.

DISCUSSION

AUTHORS' CONCLUSIONS

ACKNOWLEDGEMENTS

REFERENCES

CHARACTERISTICS OF STUDIES

DATA AND ANALYSES

Analysis 1.1. Comparison 1 Hypericum mono-preparations vs. placebo A. Dichotomous measures, Outcome 1 Responder grouped by precision - primary analysis.

Analysis 1.2. Comparison 1 Hypericum mono-preparations vs. placebo A. Dichotomous measures, Outcome 2 Responder according to HAMD.

Analysis 1.3. Comparison 1 Hypericum mono-preparations vs. placebo A. Dichotomous measures, Outcome 3 Responder according to CGI (Clinical Global Impression Index at least "much improved").

Analysis 1.4. Comparison 1 Hypericum mono-preparations vs. placebo A. Dichotomous measures, Outcome 4 Responder grouped by extract.

Analysis 1.5. Comparison 1 Hypericum mono-preparations vs. placebo A. Dichotomous measures, Outcome 5 Responder among studies from German-speaking countries and other studies.

Analysis 1.6. Comparison 1 Hypericum mono-preparations vs. placebo A. Dichotomous measures, Outcome 6 Remission (HAMD score $<8$ or $<7$ ).

Analysis 2.1. Comparison 2 Hypericum mono-preparations vs. placebo. B. Continuous measures, Outcome 1 Mean HAMD (Hamilton Rating Scale for Depression) scores after therapy.

Analysis 2.2. Comparison 2 Hypericum mono-preparations vs. placebo. B. Continuous measures, Outcome 2 Mean HAMD (Hamilton Rating Scale for Depression) scores after 2 to 3 weeks of treatment.

Analysis 2.3. Comparison 2 Hypericum mono-preparations vs. placebo. B. Continuous measures, Outcome 3 Mean HAMD (Hamilton Rating Scale for Depression) score after 4 weeks of treatment.

Analysis 2.4. Comparison 2 Hypericum mono-preparations vs. placebo. B. Continuous measures, Outcome 4 Mean HAMD (Hamilton Rating Scale for Depression) scores after 6 to 8 weeks of treatment.

Analysis 2.5. Comparison 2 Hypericum mono-preparations vs. placebo. B. Continuous measures, Outcome 5 Difference HAMD (Hamilton Rating Scale for Depression) baseline - end of treatment.

Analysis 2.6. Comparison 2 Hypericum mono-preparations vs. placebo. B. Continuous measures, Outcome 6 MADRS after treatment.

Analysis 2.7. Comparison 2 Hypericum mono-preparations vs. placebo. B. Continuous measures, Outcome 7 Difference MADRS baseline - end of treatment.

Analysis 2.8. Comparison 2 Hypericum mono-preparations vs. placebo. B. Continuous measures, Outcome 8 Mean HAMD after treatment in studies from German-speaking countries and other studies.

Analysis 2.9. Comparison 2 Hypericum mono-preparations vs. placebo. B. Continuous measures, Outcome 9 Mean Depression Scale von Zerssen (D-S) after therapy/difference baseline - after therapy.

Analysis 2.10. Comparison 2 Hypericum mono-preparations vs. placebo. B. Continuous measures, Outcome 10 Various selfrating scales.

Analysis 2.11. Comparison 2 Hypericum mono-preparations vs. placebo. B. Continuous measures, Outcome 11 Various selfrating scales in studies from German-speaking countries and other countries. 
Analysis 3.1. Comparison 3 Safety - Hypericum mono-preparations vs. placebo, Outcome 1 Number of patients discontinuing treatment/dropping out for adverse effects - primary analysis.

Analysis 3.2. Comparison 3 Safety - Hypericum mono-preparations vs. placebo, Outcome 2 Number of patients dropping out. . Analysis 3.3. Comparison 3 Safety - Hypericum mono-preparations vs. placebo, Outcome 3 Number of patients reporting adverse effects.

Analysis 4.1. Comparison 4 Hypericum mono-preparations vs. standard antidepressants. A. Dichotomous measures, Outcome 1 Responder (intent to treat) - primary analysis.

Analysis 4.2. Comparison 4 Hypericum mono-preparations vs. standard antidepressants. A. Dichotomous measures, Outcome 2 Responder (per protocol).

Analysis 4.3. Comparison 4 Hypericum mono-preparations vs. standard antidepressants. A. Dichotomous measures, Outcome 3 Responders according to CGI (Clinical Global Impression Index at least "much improved").

Analysis 4.4. Comparison 4 Hypericum mono-preparations vs. standard antidepressants. A. Dichotomous measures, Outcome 4 Responder among studies from German-speaking studies and other studies.

Analysis 4.5. Comparison 4 Hypericum mono-preparations vs. standard antidepressants. A. Dichotomous measures, Outcome 5 Remission (HAMD score $<8$ ).

Analysis 5.1. Comparison 5 Hypericum mono-preparations vs. standard antidepressants. B. Continuous measures, Outcome 1 Mean HAMD (Hamilton Rating Scale for Depression) after therapy.

Analysis 5.2. Comparison 5 Hypericum mono-preparations vs. standard antidepressants. B. Continuous measures, Outcome 2 Mean HAMD (Hamilton Rating Scale for Depression) scores after 2 or 3 weeks of treatment.

Analysis 5.3. Comparison 5 Hypericum mono-preparations vs. standard antidepressants. B. Continuous measures, Outcome 3 Mean HAMD (Hamilton Rating Scale for Depression) scores after 4 weeks of treatment.

Analysis 5.4. Comparison 5 Hypericum mono-preparations vs. standard antidepressants. B. Continuous measures, Outcome 4 Mean HAMD (Hamilton Rating Scale for Depression) scores after 6 to 8 weeks of treatment.

Analysis 5.5. Comparison 5 Hypericum mono-preparations vs. standard antidepressants. B. Continuous measures, Outcome 5 Difference HAMD (Hamilton Rating Scale for Depression) baseline - end of treatment.

Analysis 5.6. Comparison 5 Hypericum mono-preparations vs. standard antidepressants. B. Continuous measures, Outcome 6 MADRS after treatment.

Analysis 5.7. Comparison 5 Hypericum mono-preparations vs. standard antidepressants. B. Continuous measures, Outcome 7 Difference MADRS baseline - end of treatment.

Analysis 5.8. Comparison 5 Hypericum mono-preparations vs. standard antidepressants. B. Continuous measures, Outcome 8 Mean HAMD after treatment in studies from German-speaking countries and other studies.

Analysis 5.9. Comparison 5 Hypericum mono-preparations vs. standard antidepressants. B. Continuous measures, Outcome 9 Mean D-S (Depression Scale von Zerssen) scores after therapy.

Analysis 5.10. Comparison 5 Hypericum mono-preparations vs. standard antidepressants. B. Continuous measures, Outcome 10 Various self-rating scales.

Analysis 5.11. Comparison 5 Hypericum mono-preparations vs. standard antidepressants. B. Continuous measures, Outcome 11 Various self-rating scales in studies from German-speaking countries and other countries.

Analysis 6.1. Comparison 6 Safety - Hypericum mono-preparations vs. standard antidepressants, Outcome 1 Number of patients discontinuing treatment/dropping out due to adverse/side effects.

Analysis 6.2. Comparison 6 Safety - Hypericum mono-preparations vs. standard antidepressants, Outcome 2 Number of patients dropping out.

Analysis 6.3. Comparison 6 Safety - Hypericum mono-preparations vs. standard antidepressants, Outcome 3 Number of patients reporting adverse effects.

APPENDICES

WHAT'S NEW

HISTORY

CONTRIBUTIONS OF AUTHORS

DECLARATIONS OF INTEREST

SOURCES OF SUPPORT

INDEX TERMS 
[Intervention Review]

\section{St John's wort for major depression}

Klaus Linde ${ }^{1}$, Michael M Berner², Levente Kriston²

1Institut für Allgemeinmedizin / Institute of General Practice, Technische Universität München / Klinikum rechts der Isar, München, Germany. ${ }^{2}$ Department of Psychiatry and Psychotherapy, University Medical Center Freiburg, Freiburg im Breisgau, Germany

Contact address: Klaus Linde, Institut für Allgemeinmedizin / Institute of General Practice, Technische Universität München / Klinikum rechts der Isar, Wolfgangstr. 8, München, 81667, Germany. Klaus.Linde@lrz.tu-muenchen.de.

Editorial group: Cochrane Common Mental Disorders Group

Publication status and date: Edited (no change to conclusions), published in Issue 4, 2009.

Citation: Linde K, Berner MM, Kriston L. St John's wort for major depression. Cochrane Database of Systematic Reviews 2008, Issue 4. Art. No.: CD000448. DOI: 10.1002/14651858.CD000448.pub3.

Copyright @ 2009 The Cochrane Collaboration. Published by John Wiley \& Sons, Ltd.

\section{A B S T R A C T}

\section{Background}

In some countries extracts of the plant Hypericum perforatum L. (popularly called St. John's wort) are widely used for treating patients with depressive symptoms.

\section{Objectives}

To investigate whether extracts of hypericum are more effective than placebo and as effective as standard antidepressants in the treatment of major depression; and whether they have fewer adverse effects than standard antidepressant drugs.

\section{Search methods}

Trials were searched in computerised databases, by checking bibliographies of relevant articles, and by contacting manufacturers and researchers.

\section{Selection criteria}

Trials were included if they: (1) were randomised and double-blind; (2) included patients with major depression; (3) compared extracts of St. John's wort with placebo or standard antidepressants; (4) included clinical outcomes assessing depressive symptoms.

\section{Data collection and analysis}

At least two independent reviewers extracted information from study reports. The main outcome measure for assessing effectiveness was the responder rate ratio (the relative risk of having a response to treatment). The main outcome measure for adverse effects was the number of patients dropping out due to adverse effects.

\section{Main results}

A total of 29 trials (5489 patients) including 18 comparisons with placebo and 17 comparisons with synthetic standard antidepressants met the inclusion criteria. Results of placebo-controlled trials showed marked heterogeneity. In nine larger trials the combined response rate ratio (RR) for hypericum extracts compared with placebo was 1.28 (95\% confidence interval $(\mathrm{Cl}), 1.10$ to 1.49$)$ and from nine smaller trials was $1.87(95 \% \mathrm{Cl}, 1.22$ to 2.87$)$. Results of trials comparing hypericum extracts and standard antidepressants were statistically homogeneous. Compared with tri- or tetracyclic antidepressants and selective serotonin reuptake inhibitors (SSRIs), respectively, RRs were 1.02 ( $95 \% \mathrm{Cl}, 0.90$ to $1.15 ; 5$ trials) and 1.00 (95\% Cl, 0.90 to $1.11 ; 12$ trials). Both in placebo-controlled trials and in comparisons with standard antidepressants, trials from German-speaking countries reported findings more favourable to hypericum. Patients given hypericum extracts dropped out of trials due to adverse effects less frequently than those given older antidepressants (odds ratio (OR) $0.24 ; 95 \% \mathrm{Cl}, 0.13$ to 0.46 ) or SSRIs (OR $0.53,95 \% \mathrm{Cl}, 0.34-0.83$ ). 


\section{Authors' conclusions}

The available evidence suggests that the hypericum extracts tested in the included trials a) are superior to placebo in patients with major depression; b) are similarly effective as standard antidepressants; c) and have fewer side effects than standard antidepressants. The association of country of origin and precision with effects sizes complicates the interpretation.

\section{PLAIN LANGUAGE SUMMARY}

\section{St. John's wort for treating depression.}

Depression is characterised by depressed mood and/or loss of interest or pleasure in nearly all activities and a variety of other symptoms for periods longer than two weeks. Extracts of St. John's wort (botanical name Hypericum perforatum L.) are prescribed widely for the treatment of depression.

We have reviewed 29 studies in 5489 patients with depression that compared treatment with extracts of St. John's wort for 4 to 12 weeks with placebo treatment or standard antidepressants. The studies came from a variety of countries, tested several different St. John's wort extracts, and mostly included patients suffering from mild to moderately severe symptoms. Overall, the St. John's wort extracts tested in the trials were superior to placebo, similarly effective as standard antidepressants, and had fewer side effects than standard antidepressants. However, findings were more favourable to St. John's wort extracts in studies form German-speaking countries where these products have a long tradition and are often prescribed by physicians, while in studies from other countries St. John's wort extracts seemed less effective. This differences could be due to the inclusion of patients with slightly different types of depression, but it cannot be ruled out that some smaller studies from German-speaking countries were flawed and reported overoptimistic results.

Patients suffering from depressive symptoms who wish to use a St. John's wort product should consult a health professional. Using a St. John's wort extract might be justified, but important issues should be taken into account: St. John's wort products available on the market vary to a great extent. The results of this review apply only to the preparations tested in the studies included, and possibly to extracts with similar characteristics. Side effects of St. John's wort extracts are usually minor and uncommon. However, the effects of other drugs might be significantly compromised. 


\section{B A C K G R O U N D}

\section{Description of the condition}

Depressive disorders are characterised by depressed mood and/or loss of interest or pleasure in nearly all activities in the presence of other symptoms such as loss of appetite, fatigue and lack of energy, sleep disturbance, restlessness or irritability, feelings of worthlessness or inappropriate guilt, difficulty in thinking, concentrating or making decisions and thoughts of death or suicide or attempts at suicide (Candy 2008). Depressive disorders are the largest source of non-fatal disease burden in the world, accounting for $12 \%$ of years lived with disability (Ustun 2004). There are two major classification systems to diagnose depressive disorders, the Diagnostic and Statistical Manual of Mental Disorders (DSM; current version DSM-IV-TR) and the International Statistical Classification of Diseases and Related Health Problems (ICD; current version ICD-10). DSM-IV defined depressive diagnoses include recurrent or persistent major depression and minor depression. ICD-10 diagnoses include recurrent or persistent depression with mild, moderate or severe episodes. According to the DSM-IV diagnostic classification, either depressed mood or a loss of interest or pleasure in daily activities consistently for at least a two week period has to be present to diagnose a major depressive disorder. The ICD-10 system uses the term depressive episode instead of major depressive disorder, but lists similar criteria.

\section{Description of the intervention}

Major depressive episodes are most commonly treated with antidepressant medication. Current first line dugs are selective serotonin reuptake inhibitors (SSRI) or tricyclic and related antidepressants (http://guidance.nice.org.uk/CG23). However, the size of effects over placebo in clinical trials has been modest (Turner 2008; Kirsch 2008), and although SSRIs are better tolerated than older antidepressants, side effects still occur in a relevant proportion of patients.

Extracts of the plant Hypericum perforatum L. (St. John's wort), a member of the Hypericaceae family, have been used in folk medicine for a long time for a range of indications including depressive disorders. Extracts of St. John's wort are licensed and widely used in Germany for the treatment of depressive, anxiety and sleep disorders. In recent years, hypericum extracts have also become increasingly popular in other countries.

\section{How the intervention might work}

The exact mechanism of action of the antidepressant effects of hypericum extracts is still unclear. Hypericum extracts contain at least seven constituents or groups of components that may contribute to its pharmacological effects (Nahrstedt 1997). These include naphthodianthrons (e.g., hypericins), flavonoids (e.g., quercetin), biflavonoids (e.g., biapigenin), xanthons, and phloroglucinol derivatives (e.g., hyperforin). Hypericum extracts have been shown to be active in a number of standard animal models that are used to indicate antidepressant effects (Wheatley 1998; Caccia 2005; Wurglics 2006). While some isolated substances, as for example hyperforin, have been shown to have antidepressant activity, the total extract seems to be more effective (Reichling 2003).

\section{Why it is important to do this review}

Hypericum extracts have been tested in a number of clinical trials since the 1980s. The first two versions of this review and other systematic reviews published between 1995 and 2000 concluded that hypericum extracts are more effective than placebo and are comparable to older antidepressants in the treatment of mild to moderate depressive disorders (Ernst 1995; Linde 1996; Linde 1998; Kim 1999; Gaster 2000; Williams 2000). Several trials included in these reviews were criticised because they included patients with few and/or mild symptoms who did not meet criteria for major depression, were conducted by primary care physicians who were not experienced in depression research, and/or used low doses of comparator drugs (Shelton 2001). In the 2005 update of our review (Linde 2005a; Linde 2005b) several new welldesigned placebo-controlled trials were included, some of which had negative findings (Shelton 2001; HDTSG 2002) and which had spurred renewed debate about the efficacy of hypericum extracts. We systematically investigated possible reasons for the contradictory findings. We found that larger, more precise studies yielded less positive results, suggesting that small studies with a higher risk of bias might overestimate the effects of hypericum extracts over placebo. The analyses also showed that effects over placebo were less pronounced in studies restricted to patients with major depression. Finally, we had the impression that studies originating from German-speaking countries (Germany, Austria, and Switzerland) had more positive results than studies originating from other countries independently from precision and formal diagnosis, although multiple regression analyses did not identify this as an independent predictor.

Since we completed the search for our 2005 update, again, several new well-designed trials restricted to patients with major depression have been published. To sharpen the focus of this review, to reduce clinical heterogeneity, and to reflect the fact that almost all new high-quality trials of hypericum extracts are restricted to patients with major depression, we decided to limit the review now to this group of patients.

\section{OB JECTIVES}

This updated review aimed to investigate whether extracts of hypericum:

- are more effective than placebo and

- as effective as standard antidepressant drugs, and

- whether they have less adverse effects compared to standard antidepressant drugs

in the treatment of major depression in adults.

In addition, we investigated possible reasons for varying results across studies, with a focus on precision of the studies, baseline severity of depression, and country of origin.

\section{METHODS}

\section{Criteria for considering studies for this review}

Types of studies

To be included trials had to be double-blind and randomised. 


\section{Types of participants}

Patients had to suffer from major depression (meeting DSM-IV or ICD-10 criteria). Trials in children ( $<16$ years) were not eligible. In previous versions of this review (Linde 1998; Linde 2005a) trials not restricted to patients with major depression had been included.

\section{Types of interventions}

\section{Experimental intervention}

Preparations of hypericum (St. John's wort). Trials investigating combinations of hypericum with other herbs were excluded.

\section{Control intervention}

Placebo or synthetic antidepressants (tricyclic and related antidepressants, selective serotonine reuptake inhibitors, serotonine-noradrenaline reuptake inhibitors). Trials using clearly inadequate synthetic antidepressants (e.g., benzodiatepines) or a dosage clearly below the lower thresholds recommended in current guidelines (Härter 2003, ICSI 2007) were excluded.

Experimental and control treatments had to be given for at least four weeks.

\section{Main comparisons}

The following comparisons were performed:

1. hypericum extracts vs. placebo

2. hypericum extracts vs. standard antidepressants

\section{Types of outcome measures}

\section{Primary outcome}

To be included, trials had to measure clinical outcomes such as depression scales or symptoms. Trials that measured physiological parameters only were excluded. The primary outcomes of interest were

\section{Effectiveness: treatment response}

2. Safety: the proportion of patients who dropped out due to adverse effects

\section{Secondary outcomes}

1. Effectiveness: remission, depression scales such as the Hamilton Depression Scale (HAMD), the Clinical Global Impression Index (CGI), the Montgomery-Asberg Depression Rating Scale (MADRS), patient-rated depression scales

2. Safety: total proportion of drop-outs, proportion of patients reporting adverse effects

\section{Search methods for identification of studies}

For the first version of the review we searched for published and unpublished eligible trials in the following ways:

\section{Electronic searches}

a) Clinical Trials Register of the Cochrane Collaboration Depression, Anxiety \& Neurosis Group (CCDANTR)

b) database of the Cochrane Field for Complementary Medicine

c) full text searches in Medline SilverPlatter CD-ROM from 1983 onwards and Embase 1989 onwards using the terms 'St. John's wort', 'Johanniskraut' (German for St John's wort), 'hyperic ${ }^{\star \prime}$ )

d) full text searches in Psychlit and Psychindex 1987 - 1997 CD-ROM e) searches in the private database Phytodok, Munich.

\section{Searching other resources}

a) Checking bibliographies of obtained articles

b) Contacting pharmaceutical companies and authors.

There were no language restrictions.

For the updated version of the review, we searched for published and unpublished eligible trials in the following ways:

\section{Electronic searches}

For the update, regular electronic searches were performed in CCDANTR (last search July 2007) and PubMed (screening all hits for text word "hypericum", last search July 8, 2008).

\section{Searching other resources}

We screened bibliographies of published articles, and repeatedly contacted experts, researchers, and manufacturers inquiring for new trials. One reviewer $(\mathrm{KL})$ initially screened reference lists to identify controlled studies on hypericum preparations in humans. All possibly relevant studies or publications were then checked formally for eligibility.

\section{Data collection and analysis}

\section{Selection of studies}

Two reviewers independently decided on eligibility for the revised inclusion criteria. Disagreements were resolved through discussion. Due to reading errors, disagreements occurred for two trials in which not all patients had major depression and which were excluded after discussion (Vorbach 1994, Winkel 2000). In two trials both reviewers had problems with assessing eligibility: For one small, older trial (Lehrl 1993) the publication did not state that inclusion was limited to patients with major depression, but we had a statement of the sponsor obtained for our 1998 update that all patients met the criteria. As this information could not be verified for this update, we decided to exclude the trial. A Chinese trial (Gu 2001) referred to a Chinese classification. As this classification is not completely comparable to ICD-10 and DSM-IV, we decided to also exclude this trial.

\section{Data extraction and management}

Primary study characteristics and results were extracted by at least two independent reviewers using a pretested form. In particular, we extracted diagnoses and main inclusion criteria, age, gender, duration of episodes, baseline depression scores, country of origin, number and type of study centers, numbers of patients who were randomised and analysed and who completed protocols, the number and reasons for drop-outs and withdrawals, numbers of patients reporting adverse effects, and the number and type of adverse effects that were reported.

We assessed numbers of patients who were classified as responders based on score improvements on the Hamilton Rating Scale for Depression (HAMD), the Clinical Global Impression Index (CGI; subscale global improvement rating as at least "much improved"), or any other clinical response measurement. Missing or additional information was sought from authors/sponsors.

Most trials measured clinical outcomes with the Hamilton Depression Scale (HAMD) and the Clinical Global Impression Index (CGI). The HAMD is an observer-rated scale that focuses mainly on somatic symptoms of depression (Hamilton 1960). The original version includes 21 items, but a version with 17 items is more commonly used in clinical trials. Most studies using the HAMD 
report the number of 'treatment responders' (patients achieving a score less than 10 and/or less than $50 \%$ of the baseline score). When available, we extracted means and standard deviations before, during and after treatment as well as the number of 'responders'. The CGI (CGI 1970) is an observer rated instrument with three items (severity of illness, global improvement, and an efficacy index). We extracted the number of patients rated as 'much improved' or 'very much improved' for global improvement. As recently the Montgomery-Asberg Depression Rating Scale (MADRS (Montgomery 1979)) and the remission criterion for the HAMD (usually a score of less than 8 at the end of treatment) have been gaining importance as outcome criteria, we also checked all trials for the reporting of these measures. As the DS (Depression Scale von Zerssen (von Zerssen 1996)) was the most often used patient-rated instrument in the included trials, we extracted posttreatment data for this scale, if available. For additional post-hoc analyses, one reviewer (KL) also extracted data for other self-rating instruments.

\section{Assessment of risk of bias in included studies}

The main part of the update process of this review was completed before the new risk of bias tool of the Cochrane Collaboration (Higgins 2008) was available. The methodological quality of each trial was assessed by at least two independent reviewers using scales developed by A. Jadad et al. (Jadad 1996) and by one of the reviewers $(\mathrm{KL})$. The results of the quality scoring are displayed in the table of included studies.

The Jadad scale has three items adding up to a maximum score of five points. 0,1 or 2 points can be given for randomisation (explicit statement that allocation was randomised and description of an adequate generation of the random sequence), 0,1 or 2 points for double-blinding (explicit statement that patients and evaluators were blinded and that treatments were indistinguishable), 0 or 1 point for description of drop-outs and withdrawals (numbers and reasons for all compared groups separately). The display in the table of included studies is as follows (examples): 2-2-1 (full score in every item), 1-0-0 (only statement on randomisation).

The second quality scale, the "Internal Validity Scale" (IV), which has been used in other reviews on complementary medicine (Linde 1996b, Linde 1997) has six items with possible scores of $0,0.5$ or 1 point for each. Items 1 through 6 refer to statement of random allocation, adequacy of randomization concealment, baseline comparability, blinding of patients, blinding of evaluators, and likelihood of selection bias after allocation, respectively. Results are displayed by item in the table of included studies (e.g., 1-1-1-0.5-1-1 represents a full score, with the exception of blinding of patients which was stated but treatment and placebo might have been distinguishable).

The assessments in the Jadad and IV scores are solely based on the information provided in the publication (as additional information could not be gathered for all studies). In the table 'Characteristics of included studies', however, additional information provided from authors or sponsors was included. This table also contains information on allocation concealment and attrition.

\section{Measures of treatment effect}

Our primary outcome measure, to assess the effectiveness of St John's wort versus placebo and versus other antidepressants, was the proportion of responders (according to the Hamilton Depression Scale (first preference) or other responder measures (second preference)) at the end of treatment, or in case of treatment phases longer than 6 weeks, at the time point defined for primary outcome measurement by the study investigators.

Secondary outcome measures were: proportion of responders according to HAMD, proportion of responders according to CGI, mean HAMD after treatment (or, if this was not available, difference after treatment - baseline), at 2, 4, 6 to 8 weeks, and mean DS score after treatment (or, if this was not available, difference after treatment - baseline).

The main outcome measure for the safety analysis was the proportion of patients who dropped out due to adverse effects. Secondary measures were the total proportion of drop-outs and the proportion of patients reporting adverse effects.

\section{Dichotomous outcomes}

We used responder rate ratios (= relative risks = proportion of responders in the treatment group/proportion of responders in the control group) and their $95 \%$ confidence intervals for the analysis of treatment response. Responder rate ratios greater than 1 indicate better response in the hypericum group.

Due to highly variable frequency of side or adverse effects reported, odds ratios instead of rate ratios were calculated in the safety analyses. Odds ratios less than 1 indicate that fewer events occurred in the hypericum group.

\section{Continuous outcomes}

For HAMD and DS scores we calculated mean differences (also termed weighted mean differences). Negative mean differences indicate better response in the hypericum group.

\section{Unit of analysis issues}

Two trials with more than one hypericum group were included in the analyses as follows: Laakmann 1998 included an extract available on the market and an additional experimental extract with low hyperforin content which was never on the market and only used for control reasons. We did not include the data from the group receiving the experimental low-hyperforin extract in the analyses. Kasper 2006 et al tested two dosages (600 and $1200 \mathrm{mg}$ ) of an available product. We pooled the data from these two groups to prevent that the control group of this trial would have been included in the analyses twice.

\section{Dealing with missing data}

\section{Dichtomous outcomes}

Responder proportions were calculated according to the intention to treat principle, counting drop-outs as non-responders. For the comparison hypericum extracts vs. standard antidepressants responder proportions were also calculated on a per protocol basis (as this is considered more appropriate to assess the equivalence of two treatments).

\section{Continuous outcomes}

If means and standard deviations from intent to treat analysis with missing values replaced were available, we preferably used these data. In other cases we used analysis based on available data.

\section{Obtaining missing data}

If the number of patients responding to treatment and means and/ or standard deviations of HAMD scores after completion were not reported, we always tried to contact first or corresponding authors 
and/or sponsors to obtain these data. In general, we also tried to obtain other missing details on methods and secondary outcomes from authors or sponsors, but the extent to which we were doing this depended on the cooperation of authors/sponsors and the amount of missing information in the publications. We did not impute or recalculate missing standard deviations as these were unavailable only for a few secondary outcomes in a minority of trials.

We tried to contact authors and/or sponsors of 27 of the 29 included trials; for two trials (Kalb 2001; Laakmann 1998) this was considered unnecessary. We did not receive responses for five trials (Behnke 2002; Brenner 2000; Fava 2005; Harrer 1999; Moreno 2005). Very limited additional information was available or needed for three studies (Bjerkenstedt 2005; Volz 2000; Woelk 2000). We obtained relevant additional information to a variable extent from authors, sponsors, or both for the remaining 19 trials.

\section{Data synthesis}

The following comparisons were performed:

1. hypericum extracts vs. placebo: a) for dichotomous outcomes (response rate ratios); b) for continuous outcomes; c) for drop-outs and adverse effects

2. hypericum extracts vs. standard antidepressants: a) for dichotomous outcomes; b) for continuous outcomes; c) for dropouts and adverse effects

All main analyses were performed using RevMan 5.

Due to the clinical diversity of the studied populations, the hypericum extracts and the comparison drugs used, we considered that the included studies did not estimate a common underlying effect, but rather that each individual study estimated its single and unique underlying effect. Thus, the application of random effects model in all analyses seemed to be appropriate.

The primary analysis for the comparison of response rate ratios (= relative risks) under treatment with hypericum extracts or placebo was a random-effects intention to treat meta-analysis stratified by study precision (above or below median of variance of treatment effect).

\section{Assessment of heterogeneity}

Heterogeneity of trials' results was tested with the Chi-squared test, and the I-squared statistic was calculated to give an estimate of the degree of heterogeneity. I-squared values over $50 \%$ indicate considerable heterogeneity (Higgins 2003).

\section{Investigation of heterogeneity and subgroup analyses}

Predefined subgroup analyses were performed (a) including only trials with response operationalised with the HAMD score; (b) including only trials with response operationalized with the CGI; (c) for the type of extract investigated; and (d) comparing trials originating from German-speaking countries and from other countries. Weighted mean differences for HAMD scores were calculated after therapy, at 2 to $3,4,6$ to 8 weeks, and for differences compared to baseline values. For DS scores we calculated after therapy values, for MADRS score after therapy values and differences compared to baseline. As only relatively few studies used the DS, we performed an additional post-hoc random effects analysis calculating standardised mean differences for any available patient-rating scale (preferably end of treatment values, but if these were not available also differences from baseline) to investigate whether findings from physician-rated instruments could be broadly reproduced.

The primary analysis for the comparison of responder rate ratios under treatment with hypericum extracts or standard antidepressants was a random effects intent to treat meta-analysis stratified for type of synthetic antidepressant (selective serotonine inhibitors or older antidepressants). Predefined subgroup analyses were performed (a) using per protocol data; (b) stratified for country (German-speaking Europe versus other countries); (c) including only trials with response operationalised with the HAMD score; and (d) including only trials with response operationalised with the CGI.

Additional meta-regression analyses were performed to investigate the influence of country of origin (German-speaking versus not German speaking), precision and HAMD baseline values on study findings (responder ratio and mean difference of HAMD scores after treatment) both in placebo and standard antidepressants comparisons. According to current recommendations of experts (Thompson 1999, Lipsey 2000), random effects meta-regression analyses were carried out using the restricted information maximum likelihood (REML) method. A main advantage of this approach is that it accounts for residual betweentrial heterogeneity. Both univariable and multiple regression models were fitted. We calculated the proportion of explained heterogeneity variance by dividing the heterogeneity explained by the independent variable(s) through the total heterogeneity variance present in random-effects meta-analysis. When referring to a whole model, this coefficient was termed $\mathrm{R}^{2}$. When referring to the contribution of single covariates the coefficient was termed $\beta^{2}$. In univariable meta-regression analyses these coefficients are mathematically equal. In multiple meta-regression analyses, sum of $\beta^{2}$ values for all covariates may be slightly different from $R^{2}$. For all meta-regression analyses the Statistical Package for the Social Sciences (SPSS; Chicago, Illinois) v13.0 software using additional macros by Wilson (Wilson 2002; Lipsey 2000) was used.

\section{Assessment of reporting biases}

Visual analysis of funnel plots was performed to identify possible publication bias (Sterne 2001). Furthermore, the asymmetry coefficient was calculated for formal examination of publication bias (Egger 1997).

\section{RES U L T S}

\section{Description of studies}

\section{Results of the search}

A total of 79 possibly relevant studies were identified and checked formally for eligibility.

\section{Included studies}

Twenty nine trials including a total of 5489 (range 30 to 388) patients met inclusion criteria (see Characteristics of included studies).

Eighteen trials had a placebo-control group (Bjerkenstedt 2005; Bracher 2001; Fava 2005; Gastpar 2006; HDTSG 2002; Hänsgen 1996; Kalb 2001; Kasper 2006; Laakmann 1998; Lecrubier 2002; Montgomery 2000; Moreno 2005; Philipp 1999; Schrader 1998; Shelton 2001; Uebelhack 2004; Volz 2000; Witte 1995), and 17 trials compared hypericum with standard antidepressants (Behnke 2002; Bjerkenstedt 2005; Brenner 2000; Fava 2005; Gastpar 2005; Gastpar 2006; Harrer 1993; Harrer 1999; HDTSG 2002; Moreno 2005; 
Philipp 1999; Schrader 2000; Szegedi 2005; van Gurp 2002; Vorbach 1997; Wheatley 1997; Woelk 2000). Six trials had both a placebo and a standard antidepressant control group (Bjerkenstedt 2005; Fava 2005; Gastpar 2006; HDTSG 2002; Moreno 2005; Philipp 1999). Eight trials are newly included since the last update (Bracher 2001; Fava 2005; Gastpar 2005; Gastpar 2006; Kasper 2006; Moreno 2005; Szegedi 2005; Uebelhack 2004) and one trial which had been included based on an abstract reference only is now included fully (Bjerkenstedt 2005). These eight new trials included a total of 1947 (range 72 to 388) patients. Details on patients, methods, interventions, outcomes, and results of all included studies are described in the table of included studies.

\section{Types of participants}

The severity of depression was described as mild to moderate in 19 trials, and as moderate to severe in 9 trials (one trial did not classify severity). Eighteen trials were from German-speaking countries, four from the US, two from the UK, and one each from Brazil, Canada, Denmark, France and Sweden. Patients were recruited in private practices in all trials from German-language countries, in the trials from Sweden (Bjerkenstedt 2005) and Canada (van Gurp 2002), and in one of the trials from the UK (Wheatley 1997). The second trial from the UK (Montgomery 2000) and the trial from France (Lecrubier 2002) were performed both in private practices and psychiatric outpatient departments. Three trials from the US (Shelton 2001; HDTSG 2002; Fava 2005) and the Brazilian trial (Moreno 2005) were performed in academic and/or community psychiatry research clinics. Two trials from the US and Denmark (Brenner 2000; Behnke 2002) did not report on the setting.

\section{Types of intervention}

A variety of hypericum preparations were studied in the trials. The range of daily extract doses varied between 240 and 1800 $\mathrm{mg}$, but in most trials 500 to $1200 \mathrm{mg}$ were used. The standard antidepressants used as active comparators were fluoxetine (6 trials, dosage 20 to $40 \mathrm{mg}$ ), sertraline (4 trials, 50 to $100 \mathrm{mg}$ ), imipramine (in 3 trials, dosage 100 to $150 \mathrm{mg}$ ), citalopram ( 1 trial, $20 \mathrm{mg}$ ), paroxetine (1 trial, 20 to $40 \mathrm{mg}$ ), maprotiline (1 trial, 75 $\mathrm{mg}$ ), and amitriptyline (1 trial, $75 \mathrm{mg}$ ). The comparator dosage of maprotiline and amitriptyline were slightly below of those recommended in current guidelines (Härter 2003, ICSI 2007) and in most other studies at the minimum of recommended dosages. The treatment periods lasted 4 (1 trial), 6 (19), 7 (1), 8 (5) or 12 weeks (4 trials). Four trials included some long-term follow-up or continuation treatment after the main trial phase (Brenner 2000; Gastpar 2005; Shelton 2001; Szegedi 2005).

\section{Types of outcome}

The most frequently used instrument used for outcome measurement was the Hamilton Rating Scale for Depression (used in all trials). A variety of other ratings scales and instruments were used in addition.

\section{Excluded studies}

Fifty trials (see Characteristics of excluded studies) did not meet inclusion criteria: eight trials were not limited to patients with depression (Albertini 1986; Bendre 1980; Dittmer 1992; Hottenrott 1997; Maisenbacher 1995; Panijel 1985; Sindrup 2000; Volz 2002), four trials were on prevention or treatment of depressive symptoms in patients suffering primarily from other diseases (Häring 1996; Li 2005; Mo 2004; Werth 1989), two measured physiological parameters only (as EEG) in depressed patients
(Czekalla 1997; Kugler 1990b), five did not include a placebo or standard drug comparison group (Bernhadt 1993; Lenoir 1999; Martinez 1993; Spielberger 1985; Zeller 2000), eight involved healthy volunteers (Brockmöller 1997; Herberg 1992; Johnson 1992; Johnson 1993; Schmidt 1993b; Schulz 1993; Staffeldt 1993; Wienert 1991), three tested combinations of hypericum and other herbal extracts (Ditzler 1992; Kniebel 1988; Steger 1985), and two compared hypericum extract with medications which are no longer considered adequate for depression (diazepam or bromazepam) (Kugler 1990a; Warnecke 1986); one of these trials also was not explicitly randomized. Due to the new exclusion criterion, we excluded 17 trials not restricted to patients with major depression. Fifteen had been included in the previous version of the review (Halama 1991; Harrer 1991; Hoffmann 1979; Hübner 1993; König 1993; Lehrl 1993; Osterheider 1992; Quandt 1993; Reh 1992; Schlich 1987; Schmidt 1989; Schmidt 1993; Sommer 1994; Vorbach 1994; Winkel 2000) while two were not (Agrawal 1994, for which it had not been possible to obtain a full copy and Gu 2001, which was newly identified in the update searches). Finally, we excluded one previously included trial as the standard antidepressant treatment was far below recommended dosages (30 mg Amitriptyline daily; Bergmann 1993).

\section{Risk of bias in included studies}

The majority of the trials were of high quality. The median quality scores were 5 (out of 5 , range 2 to 5 ) for the Jadad scale and 4.5 (out of 6 ; range 2 to 6 ) for the IV scale (see quality rating of the single trials in the Characteristics of included studies).

\section{Sequence generation/allocation concealment}

The information on how the random sequence was generated was reported or provided on request for 18 trials (in all cases a computer program). Twenty two trials reported an adequate method of allocation concealment (most often consecutively numbered medication).

\section{Blinding}

All trials were described as double-blind, but only one trial reported that blinding was tested (HDTSG 2002). In this three-armed trial (hypericum vs. sertraline vs. placebo) about a third (as expected by chance alone) of guesses made by physicians were correct for hypericum and placebo patients, but in $66 \%$ of sertraline patients $(p=0.001)$.

\section{Incomplete outcome data}

In some trials attrition rates were high (for example, Fava 2005; see Characteristics of included studies). All placebo-controlled trials included an intent to treat analysis.

\section{Effects of interventions}

\section{Comparison 1: Hypericum extracts versus placebo}

\section{Effectiveness}

\section{a) Responder analyses}

Sixteen of the 18 placebo-controlled trials reported the number of patients classified as responders based on score reduction on the HAMD scale, one trial reported response according to the MADRS scale (Bracher 2001), and one trial only reported the proportion of patients rated at least as "improved" for the CGI (Volz 2002). Patients receiving hypericum extracts were significantly more likely to be responders $(\mathrm{RR}=1.48 ; 95 \% \mathrm{Cl} 1.23$ to 1.77 ; see comparison 
1.1 and Figure 1) but study results were highly heterogeneous $\left(I^{2}=\right.$ $75 \%)$. Effects in favour of hypericum extracts were less pronounced in more precise trials ( $\mathrm{RR}=1.28 ; 95 \% \mathrm{Cl} 1.10$ to 1.49 ) compared to less precise trials $(\mathrm{RR}=1.87 ; 95 \% \mathrm{Cl} 1.22$ to 2.87$)$ but heterogeneity was still strong in both subgroups $\left(I^{2}=61 \%\right.$ and $79 \%$, respectively).

Figure 1. Forest plot of comparison: 1 Hypericum mono-preparations vs. placebo A. Dichotomous measures, outcome: 1.1 Responder - grouped by precision - primary analysis.

\begin{tabular}{|c|c|c|c|c|c|c|c|c|}
\hline Stucty or Subgroup & $\begin{array}{l}\text { Hyperic } \\
\text { Events }\end{array}$ & Total & Placebo & bo & Weight & $\begin{array}{c}\text { Risk Ratio } \\
\text { M-H, Random, 95唵 Cl }\end{array}$ & \multicolumn{2}{|c|}{$\begin{array}{c}\text { Risk Ratio } \\
\text { M-H, Random, 95\% } \mathrm{Cl}\end{array}$} \\
\hline \multicolumn{9}{|c|}{ 1.1.1 Less precise trials } \\
\hline Bjerkenstedt 2005 & 22 & 54 & 21 & 55 & $5.3 \%$ & $1.07[0.67,1.70]$ & & \\
\hline Fava 2005 & 17 & 45 & 9 & 43 & $3.7 \%$ & $1.80[0.90,3.60]$ & & \\
\hline Hänsgen 1996 & 35 & 53 & 12 & 55 & $4.8 \%$ & $3.03[1.77,5.17]$ & & \\
\hline Kalb 2001 & 23 & 37 & 15 & 35 & $5.4 \%$ & $1.45[0.92,2.29]$ & & \\
\hline Laakmann 1998 & 24 & 49 & 16 & 49 & $5.1 \%$ & $1.50[0.92,2.46]$ & & \\
\hline Moreno 2005 & 4 & 20 & 11 & 26 & $2.4 \%$ & $0.47[0.18,1.27]$ & & \\
\hline Schrader 1998 & 45 & 80 & 12 & 79 & $4.6 \%$ & $3.70[2.12,6.46]$ & & \\
\hline Shelton 2001 & 26 & 98 & 19 & 102 & $4.9 \%$ & $1.42[0.84,2.40]$ & & \\
\hline $\begin{array}{l}\text { Uebelhack } 2004 \\
\text { Subtotal (95\% Cl) }\end{array}$ & 41 & $\begin{array}{r}70 \\
506\end{array}$ & 4 & $\begin{array}{r}70 \\
514\end{array}$ & $\begin{aligned} 2.4 \% \\
38.8\end{aligned}$ & $\begin{array}{r}10.25[3.88,27.09] \\
\mathbf{1 . 8 7}[1.22,2.87]\end{array}$ & & \\
\hline \multicolumn{9}{|c|}{$\begin{array}{l}\text { Heterogeneity: } \operatorname{Tau}^{2}=0.32 ; \mathrm{Ch}^{2}=38.33, \mathrm{df}=8(\mathrm{P}<0.00001) ;\left.\right|^{2}=79 \% \\
\text { Test for overall effect: } \mathrm{Z}=2.88(\mathrm{P}=0.004)\end{array}$} \\
\hline \multicolumn{9}{|c|}{ 1.1.2 More precise trials } \\
\hline Bracher 2001 & 64 & 109 & 48 & 109 & $7.0 \%$ & $1.33[1.02,1.74]$ & & \\
\hline Gastpar 2006 & 71 & 131 & 51 & 130 & $7.0 \%$ & $1.38[1.06,1.80]$ & & \\
\hline HDTSG 2002 & 46 & 113 & 56 & 116 & $6.8 \%$ & $0.84[0.63,1.13]$ & & \\
\hline Kasper 2006 & 159 & 243 & 26 & 81 & $6.5 \%$ & $2.04[1.47,2.83]$ & & \\
\hline Lecrubier 2002 & 98 & 186 & 80 & 189 & $7.4 \%$ & $1.24[1.00,1.54]$ & & 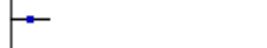 \\
\hline Montgomery 2000 & 55 & 123 & 57 & 124 & $6.9 \%$ & $0.97[0.74,1.28]$ & & - \\
\hline Philipp 1999 & 67 & 106 & 22 & 47 & $6.4 \%$ & $1.35[0.96,1.89]$ & & \\
\hline Volz 2000 & 46 & 70 & 34 & 70 & $6.8 \%$ & $1.35[1.01,1.82]$ & & $\longrightarrow$ \\
\hline $\begin{array}{l}\text { Witte } 1995 \\
\text { Subtotal (95\% Cl) }\end{array}$ & 34 & $\begin{array}{r}48 \\
1129\end{array}$ & 25 & $\begin{array}{r}49 \\
915\end{array}$ & $\begin{array}{r}6.5 \% \\
61.2 \%\end{array}$ & $\begin{array}{l}1.39[1.00,1.93] \\
1.28[1.10,1.49]\end{array}$ & & $\overrightarrow{0}$ \\
\hline \multicolumn{9}{|c|}{$\begin{array}{l}\text { Heterogeneity: } \text { Tau }^{2}=0.03 ; \mathrm{Chi}^{2}=20.33, \mathrm{df}=8(\mathrm{P}=0.009) ; \mathrm{I}^{2}=61 \% \\
\text { Test for overall effect: } Z=3.17(\mathrm{P}=0.002)\end{array}$} \\
\hline Total $(95 \% \mathrm{Cl})$ & & 1635 & & 1429 & $100.0 \%$ & $1.48[1.23,1.77]$ & & \\
\hline Total events & 877 & & 518 & & & & & \\
\hline $\begin{array}{l}\text { Heterogeneity: Tau }{ }^{2} \\
\text { Test for overall effec }\end{array}$ & $\begin{array}{l}0.10 ; \mathrm{Chi} \\
\mathrm{Z}=4.21\end{array}$ & $\begin{array}{l}=68.8 \\
P=0.0\end{array}$ & $\begin{array}{l}37, \mathrm{df}=17 \\
001)\end{array}$ & $7(\mathrm{P} \leq 0$ & $00001) ;$ & $P^{2}=75 \%$ & $\begin{array}{ccc}1 & 1 & 1 \\
0.1 & 0.2 & 0.5 \\
\text { favours placebo }\end{array}$ & $\begin{array}{c}510 \\
\text { hypericum }\end{array}$ \\
\hline
\end{tabular}

Findings were similar if response rates were based only on the trials reporting response according to the HAMD scale, or on the CGI (see comparisons 1.2 and 1.3). If trials investigating defined extracts were analysed separately (subgroups of trials testing the same extracts; see comparison 1.4), heterogeneity was strong in 3 of 4 subgroups.
Trials from German-speaking countries reported more positive findings than trials from other countries (RR $=1.78 ; 95 \% \mathrm{Cl} 1.42$ to 2.25 vs.1.07; $95 \% \mathrm{Cl} 0.88$ to 1.31 , respectively; see comparison 1.5 and Figure 2). Six trials reported remission rates. These were significantly higher in patients receiving hypericum extracts than in those receiving placebo $\left(\mathrm{RR}=2.77 ; 95 \% \mathrm{Cl} 1.80\right.$ to $4.26 ; \mathrm{I}^{2}=29 \%$; see comparison 1.6). 
Figure 2. Forest plot of comparison: 1 Hypericum mono-preparations vs. placebo A. Dichotomous measures, outcome: 1.5 Responder among studies from German-speaking countries and other studies.

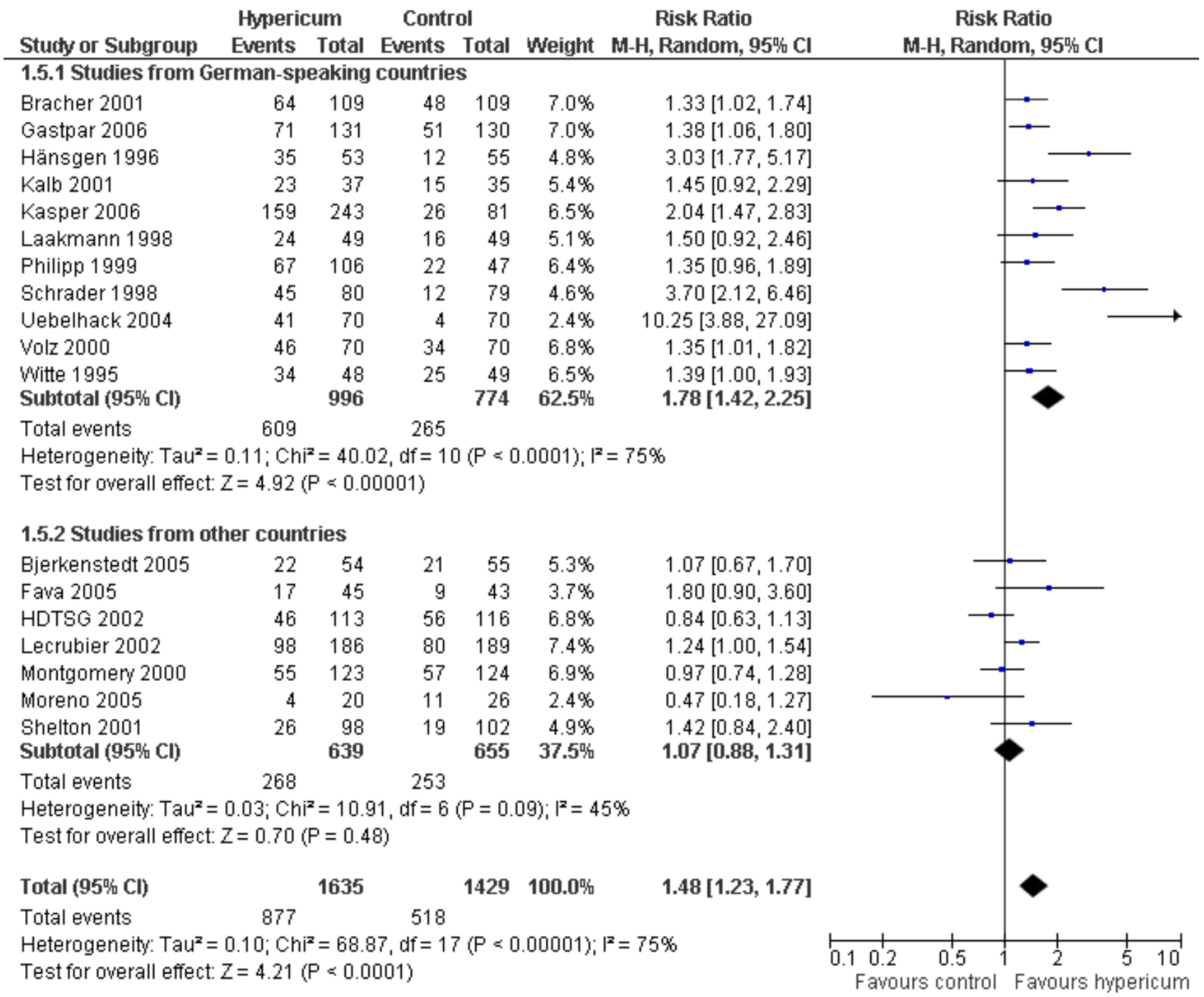

There was significant funnel plot asymmetry for the main responder analysis (coefficient $=2.19, p=0.03$; Figure 3 ). 
Figure 3. Funnel plot of comparison: 1 Hypericum mono-preparations vs. placebo A. Dichotomous measures, outcome: 1.1 Responder - grouped by precision - primary analysis.

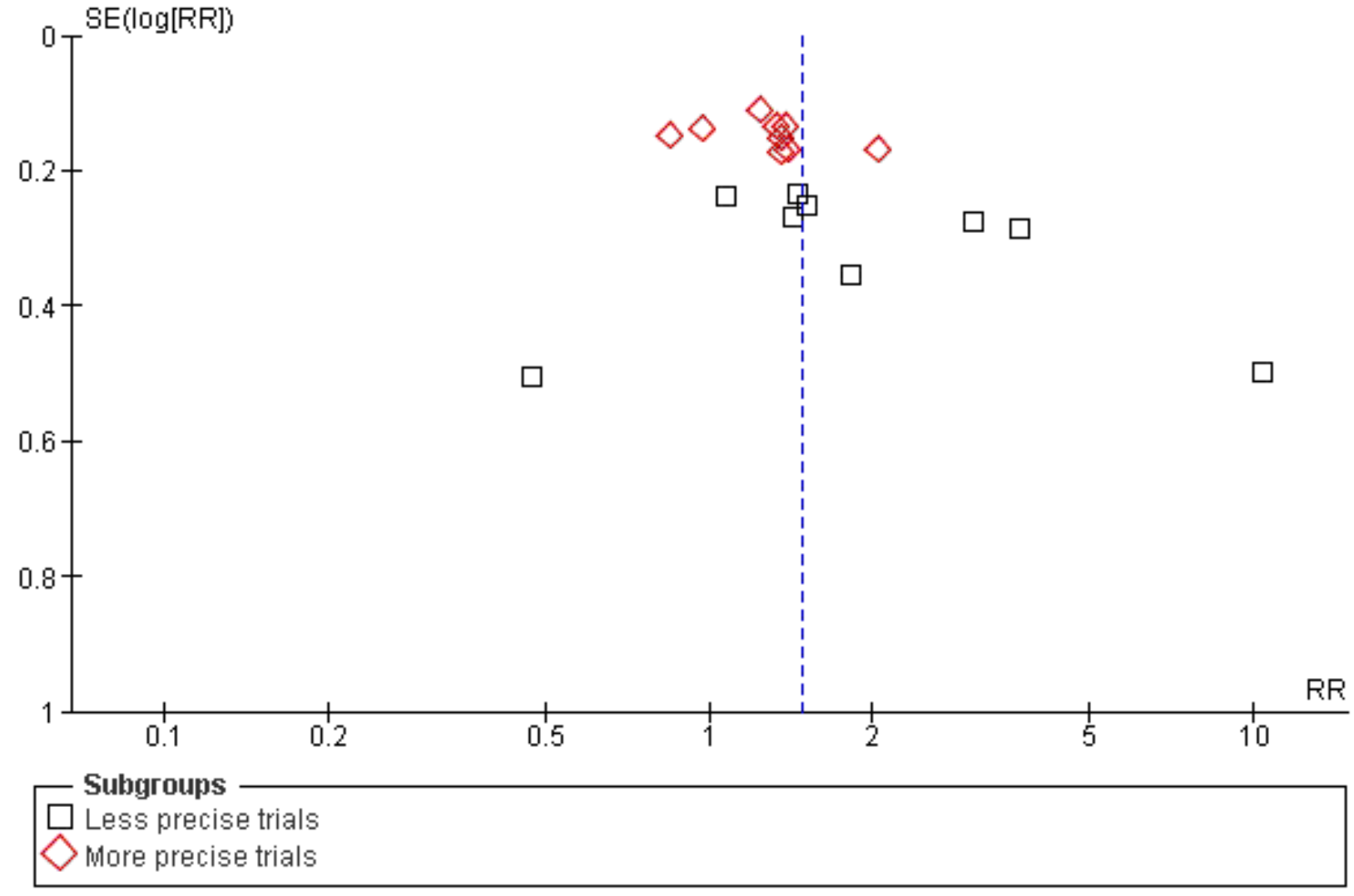

In univariable meta-regression analyses, country of origin (studies from German-speaking countries showing larger effect sizes; $p=$ 0.002 ), precision (more precise studies showing smaller effects; $p=$ 0.032 ) and baseline values (higher values associated with smaller effect sizes; $p=0.048$ ) were significantly associated with effects sizes. In multiple analyses the association remained significant for country of origin $(p=0.035)$ and precision $(p=0.017)$ but became non-significant for HAMD baseline values. Altogether over half of the variance $\left(R^{2}=0.51\right)$ could be explained by these three variables. Findings of meta-regression analyses are summarised in Appendix 1.

\section{b) Analyses of depression scales}

Analyses based on mean HAMD values yielded similar findings. At the completion of treatment HAMD values were $3.04(95 \% \mathrm{Cl}$ 1.78 to 4.29 ) score points lower in hypericum groups compared to placebo groups, but there was strong heterogeneity $\left(1^{2}=\right.$ $86 \%$; see comparison 2.1). Effects over placebo were significant after 2 (comparison 2.2), 4 (comparison 2.3), 6 to 8 weeks of treatment (comparison 2.4), and for changes from baseline to end of treatment (comparison 2.5). Significant effects over placebo were also reported for the MADRS (comparisons 2.6, and 2.7). Studies from German-language countries reported much larger effects over placebo (weighted mean difference $=4.29,95 \% \mathrm{Cl} 2.97$ to 5.61 score points; comparison 2.8) than studies from other countries (MD $=0.77$ score points, $95 \% \mathrm{Cl} 0.20$ to 1.74 score points).
There was no significant funnel plot asymmetry (coefficient in the analysis of HAMD values at completion of treatment $=-2.12, p=$ 0.35 .

In multiple meta-regression analysis, country of origin was significantly associated with effects size (larger effects in trials from German-speaking countries; $p<0.001$ ) but not precision and HAMD baseline values $\left(R^{2}=0.63\right.$; see Appendix 1$)$.

The four trials reporting results for the patient-rated von Zerssen Depression Scale (D-S) showed a significant effect of hypericum extracts over placebo (comparison 2.9). Post-hoc analyses using available data from 12 placebo-controlled trials for a variety of selfrating instruments also confirmed analyses based on physicianrated outcomes. The pooled standardised mean difference (SMD) was $-0.47\left(95 \% \mathrm{Cl}-0.64\right.$ to $-0.30 ; \mathrm{I}^{2}=74 \%$; see comparison 2.10). Trials from German-speaking countries again reported more favourable findings than trials from other countries (SMDs of -0.57 and -0.17 respectively; see comparison 2.11 ).

\section{Safety}

Primary outcome

The number of patients dropping out for adverse effects was similar among patients receiving hypericum extracts and placebo $(\mathrm{OR}=$ $0.92,95 \% \mathrm{Cl} 0.45$ to $1.88, \mathrm{I}=0 \%$; see comparison 3.1 ).

Secondary outcomes 
The total number of patients dropping out and the number of patients dropping out for any reason were similar among patients receiving hypericum extracts and placebo (comparisons 3.2 and 3.3).

\section{Comparison 2: Hypericum extracts versus standard antidepressants}

\section{Effectiveness}

a) Responder analyses
All 17 trials comparing hypericum extracts to standard antidepressant treatment reported the number of responders according to the HAMD score. Based on an intention to treat approach the pooled responder rate ratio was 1.01 for all 17 trials $\left(95 \% \mathrm{Cl} 0.93\right.$ to $1.09 ; \mathrm{I}^{2}=17 \%$; see comparison 4.1 and Figure 4). For the five trials comparing hypericum extracts with older antidepressants, the pooled estimate was $1.02(95 \% \mathrm{Cl} 0.90$ to 1.15 ; $\left.1^{2}=0 \%\right)$, and 1.00 for the 12 trials with selective serotonine reuptake inhibitors $\left(95 \% \mathrm{Cl} 0.90\right.$ to $\left.1.12 ;\left.\right|^{2}=29 \%\right)$.

Figure 4. Forest plot of comparison: 4 Hypericum mono-preparations vs. standard antidepressants. A. Dichotomous measures, outcome: 4.1 Responder (intent to treat) - primary analysis.

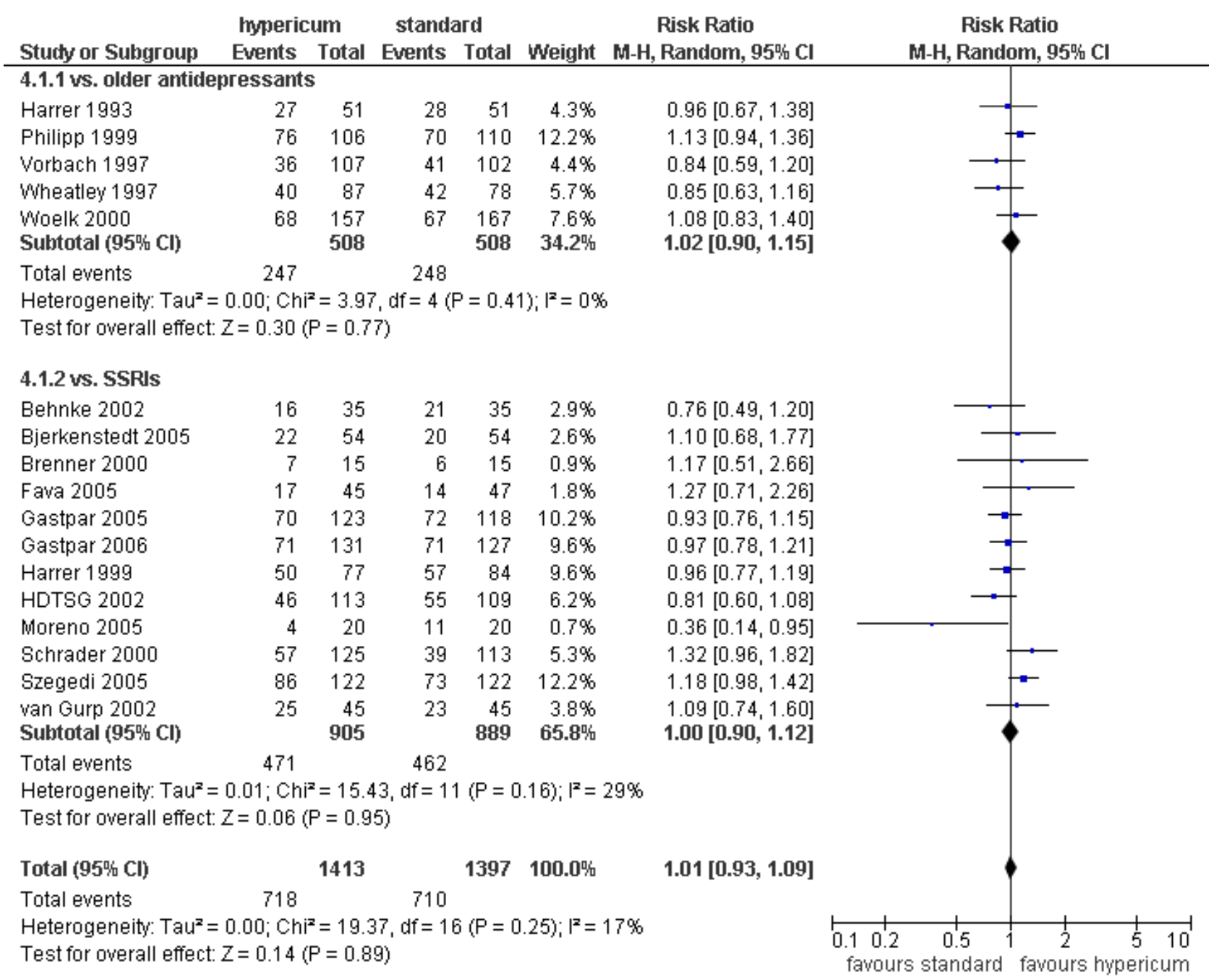

If analyses were based on per protocol data, the pooled responder rate ratio was $0.96\left(95 \% \mathrm{Cl} 0.88\right.$ to $1.05 ; I^{2}=43 \%$; see comparison 4.2). Analysis based on the $\mathrm{CGI}$ also found no relevant differences $\left(\mathrm{RR}=1.01 ; 95 \% \mathrm{Cl} 0.94\right.$ to $1.09 ; I^{2}=24 \%$; see comparison 4.3). In trials originating from German-speaking countries findings were slightly more favourable to hypericum than in trials from other countries (RR 1.04 and 0.90, respectively; see comparison 4.4 and Figure 5). In the four trials reporting remission rates the response rate ratio was $1.24\left(95 \% \mathrm{Cl} 1.02\right.$ to $1.50 ; I^{2}=0 \%$; see comparison 4.5$)$. 
Figure 5. Forest plot of comparison: 4 Hypericum mono-preparations vs. standard antidepressants. A. Dichotomous measures, outcome: 4.4 Responder among studies from German-speaking studies and other studies.

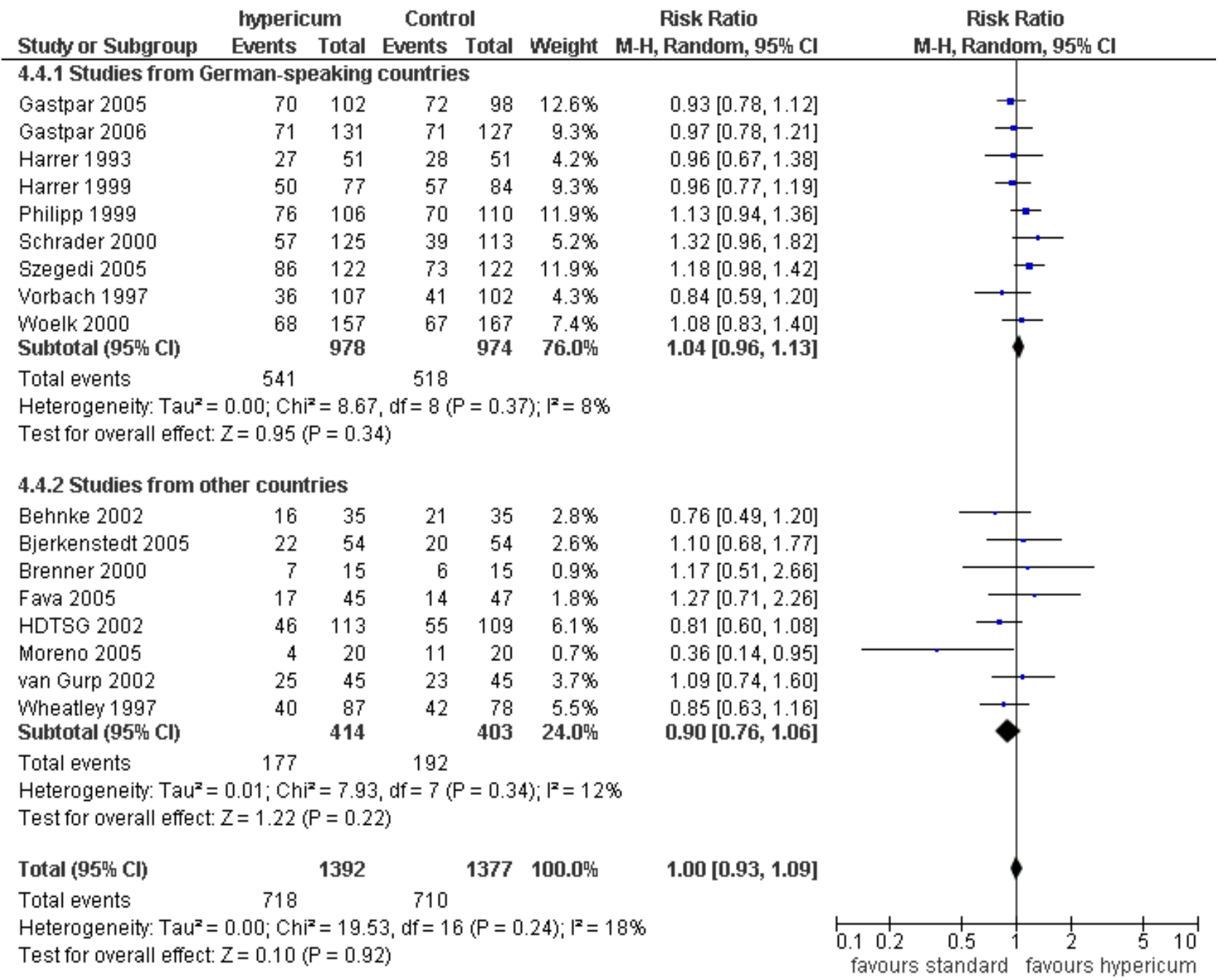

The asymmetry coefficient for the main responder analysis was $-1.07(p=0.09$; see funnel plot in Figure 6$)$. In univariable metaregression analysis, there was a significant association between country of origin and response (trials from German-speaking countries favouring hypericum; $p=0.037$ ). In the multivariable meta-regression analysis, none of the three tested predictors proved significant $\left(R^{2}=0.24\right)$. 
Figure 6. Funnel plot of comparison: 4 Hypericum mono-preparations vs. standard antidepressants. A. Dichotomous measures, outcome: 4.1 Responder (intent to treat) - primary analysis.

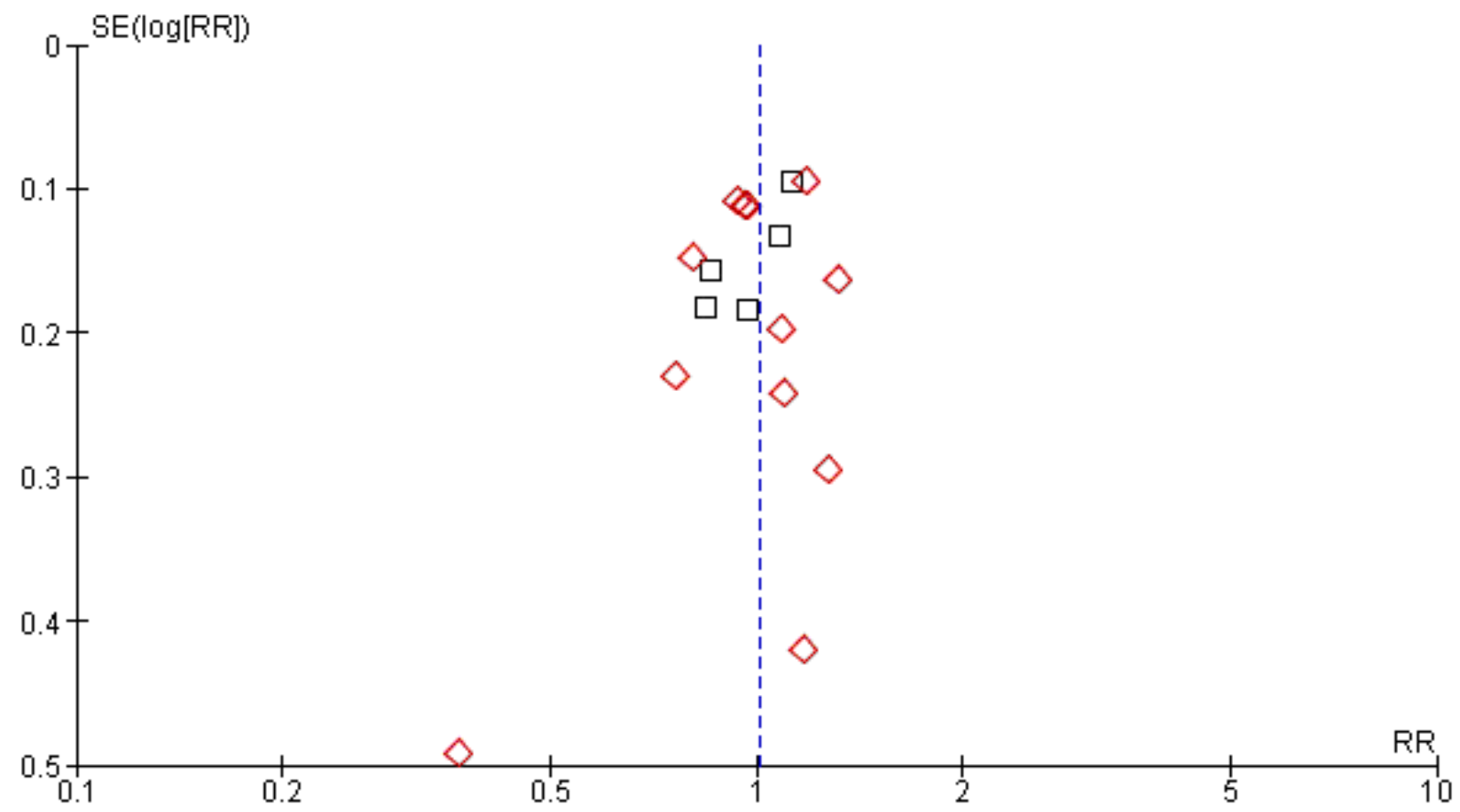

Subgroups

vs. older antidepressants

vs. SSRIS

\section{b) Analyses of depression scales}

Analyses based on HAMD scores confirmed the findings of the responder analysis (see comparisons 5.1 to 5.5, and 5.8). Analyses of MADRS- and D-S-values are difficult to interpret, as only few trials reported these outcomes (see comparisons 5.6, 5.7, 5.9). There was no funnel plot asymmetry $(0.30, p=0.73)$. In the multivariable meta-regression analysis, trials with higher HAMD baseline values showed less favourable results $(p=0.010)$, while country of origin and precision had no significant influence $\left(R^{2}=0.44\right)$.

Again, post-hoc analyses using available data for a variety of selfrating instruments from 10 trials comparing hypericum extracts and standard antidepressants confirmed analyses based on physician- rated outcomes. The pooled SMD was $0.01\left(95 \% \mathrm{Cl}-0.13\right.$ to $0.15 ; \mathrm{I}^{2}=$ $43 \%$; see comparison 5.10). The pooled SMDs in trials from Germanspeaking countries was -0.02 compared to 0.10 in trials from other countries (comparison 5.11).

\section{Safety}

\section{Primary outcome}

Patients allocated to hypericum extracts were less likely to drop out from studies due to adverse effects than patients allocated to older standard antidepressants (OR $=0.24 ; 95 \% \mathrm{Cl} 0.13$ to $\left.0.46 ; \mathrm{I}^{2}=0 \%\right)$ or to SSRIs (OR $=0.53 ; 95 \% \mathrm{Cl} 0.34$ to $0.83 ; \mathrm{I}^{2}=0 \%$; see comparison 6.1 and Figure 7). 
Figure 7. Forest plot of comparison: 6 Safety - Hypericum mono-preparations vs. standard antidepressants, outcome: 6.1 Number of patients discontinuing treatment/dropping out due to adverse/side effects.

\begin{tabular}{|c|c|c|c|c|c|c|c|c|}
\hline \multirow[b]{2}{*}{ Stucły or Subgroup } & \multicolumn{2}{|c|}{ mypericum } & \multicolumn{2}{|c|}{ standard } & \multirow[b]{2}{*}{ Weight } & \multirow{2}{*}{$\begin{array}{l}\text { Odds Ratio } \\
\text { M-H, Random, 95\% Cl }\end{array}$} & \multirow{2}{*}{\multicolumn{2}{|c|}{$\begin{array}{l}\text { Odds Ratio } \\
\text { M-H, Random, 95\% Cl }\end{array}$}} \\
\hline & Events & Total & Events & Total & & & & \\
\hline \multicolumn{9}{|c|}{ 6.1.1 ws. older antidepressants } \\
\hline Harrer 1993 & 0 & 51 & 2 & 51 & $1.4 \%$ & $0.19[0.01,4.11]$ & & \\
\hline Philipp 1999 & 0 & 106 & 1 & 110 & $1.3 \%$ & $0.34[0.01,8.51]$ & & \\
\hline Vorbach 1997 & 1 & 107 & 8 & 102 & $3.1 \%$ & $0.11[0.01,0.90]$ & & \\
\hline Wheatley 1997 & 7 & 87 & 13 & 78 & $14.2 \%$ & $0.44[0.16,1.16]$ & & \\
\hline Woelk 2000 & 4 & 157 & 26 & 167 & $11.7 \%$ & $0.14[0.05,0.42]$ & & \\
\hline Subtotal (95\% Cl) & & 508 & & 508 & 31.7\% & $0.24[0.13,0.46]$ & & \\
\hline Total events & 12 & & 50 & & & & & \\
\hline \multirow{2}{*}{\multicolumn{9}{|c|}{$\begin{array}{l}\text { Heterogeneity: } \mathrm{Tau}^{2}=0.00 ; \mathrm{Chi}^{2}=3.03, \mathrm{df}=4(\mathrm{P}=0.55) ; \mathrm{I}^{2}=0 \% \\
\text { Test for overall effect: } Z=4.27(P=0.0001)\end{array}$}} \\
\hline & & & & & & & & \\
\hline \multicolumn{9}{|l|}{ 6.1.2 us. SSRIs } \\
\hline Behnke 2002 & 2 & 35 & 2 & 35 & $3.3 \%$ & $1.00[0.13,7.53]$ & & \\
\hline Bjerkenstedt 2005 & 4 & 57 & 4 & 56 & $6.5 \%$ & $0.98[0.23,4.13]$ & & \\
\hline Brenner 2000 & 2 & 15 & 2 & 15 & $3.1 \%$ & $1.00[0.12,8.21]$ & & \\
\hline Fava 2005 & 0 & 45 & 2 & 47 & $1.4 \%$ & $0.20[0.01,4.28]$ & & \\
\hline Gastpar 2005 & 5 & 123 & 10 & 118 & $11.1 \%$ & $0.46[0.15,1.38]$ & & \\
\hline Gastpar 2006 & 4 & 131 & 11 & 127 & $9.9 \%$ & $0.33[0.10,1.07]$ & & \\
\hline Harrer 1999 & 6 & 77 & 8 & 84 & $11.0 \%$ & $0.80[0.27,2.43]$ & & \\
\hline HDTSG 2002 & 2 & 113 & 5 & 111 & $4.9 \%$ & $0.38[0.07,2.01]$ & & \\
\hline Schrader 2000 & 0 & 125 & 1 & 114 & $1.3 \%$ & $0.30[0.01,7.47]$ & & \\
\hline Szegedi 2005 & 4 & 125 & 8 & 126 & $9.0 \%$ & $0.49[0.14,1.66]$ & & \\
\hline van Gurp 2002 & 3 & 45 & 7 & 45 & $6.7 \%$ & $0.39[0.09,1.61]$ & & \\
\hline Subtotal (95\% Cl) & & 891 & & 878 & $68.3 \%$ & $0.53[0.34,0.83]$ & & \\
\hline Total events & 32 & & 60 & & & & & \\
\hline \multirow{2}{*}{\multicolumn{9}{|c|}{$\begin{array}{l}\text { Heterogeneity: } \operatorname{Tau}^{2}=0.00 ; \mathrm{Chi}^{2}=3.52, \mathrm{df}=10(\mathrm{P}=0.97) ; \mathrm{I}^{2}=0 \% \\
\text { Test for overall effect: } Z=2.80(P=0.005)\end{array}$}} \\
\hline & & & & & & & & \\
\hline Total (95\% Cl) & & 1399 & & 1386 & $100.0 \%$ & $0.41[0.29,0.60]$ & & \\
\hline Total events & 44 & & 110 & & & & & \\
\hline \multicolumn{7}{|c|}{$\begin{array}{l}\text { Heterogeneity: } \text { Tau }^{2}=0.00 ; \mathrm{Chi}^{2}=10.42, \mathrm{df}=15(\mathrm{P}=0.79) ; \mathrm{I}^{2}=0 \% \\
\text { Test for overall effect: } Z=4.72(P \leq 0.00001)\end{array}$} & 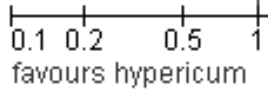 & $\frac{1}{2}$ \\
\hline
\end{tabular}

\section{Secondary outcomes}

Attrition for any reason was significantly lower for hypericum extracts compared to older antidepressants $(\mathrm{OR}=0.67 ; 95 \% \mathrm{Cl} 0.47$ to $0.95 ; I^{2}=0 \%$ ), but not compared to SSRIs (OR $=0.83 ; 95 \% 0.63$ to $1.08 ; I^{2}=0 \%$; see comparison 6.2 ).

The number of patients reporting side effects was significantly higher in patients receiving older standard antidepressants $(\mathrm{OR}=$ $0.39 ; 95 \% 0.30$ to $0.50 ; I^{2}=0 \%$ ); compared to SSRIs, the difference just missed significance ( $\mathrm{OR}=0.70 ; 95 \% \mathrm{Cl} 0.49$ to $1.00 ; \mathrm{I}^{2}=57 \%$; see comparison 6.3).

\section{DISCUSSION}

\section{Summary of main results}

Overall, the findings from newer trials seem to corrobate the evidence in favour of hypericum extracts. The available data suggest that the hypericum extracts tested in the included trials a) are superior to placebo in patients with major depression; b) are similarly effective as standard antidepressants; c) and have less side effects than standard antidepressants. There are two issues which complicate the interpretation of our findings: 1) While the influence of precision on study results in placebo-controlled trials is less pronounced in this updated version of our review compared to the previous version (Linde 2005a), results from more precise trials still show smaller effects over placebo than less precise trials. 2) Results from German-language countries are considerably more favourable for hypericum than trials from other countries.

\section{Interpretation of the findings and limitations}

For this update we excluded for the first time from our review all trials which were not restricted to patients with major depression. This does not mean that we believe that major depression is necessarily the only or best indication for hypericum extracts. Some authors argue that patients with signs of atypical depression might be particularly suited for treatment with hypericum extracts (Murck 2002, Murck 2005), the National Institutes of Health are currently funding a trial in patients with minor depression (www.clinicaltrials.gov, identifier NCT00048815), and the findings from older trials (some of which, however, seem methodologically questionable) not restricted to patients with major discussion were very positive (Linde 1998). As pointed out in the introduction, we now focus on major depression to make our review better comparable to overviews on standard antidepressants, to have 
a more comparable set of studies for analysis, and also because almost all new trials of hypericum extracts are on this indication.

In spite of the tightened inclusion criteria, the findings of the placebo-controlled trials are still quite heterogeneous. In the trials a variety of hypericum extracts has been tested and daily doses cover a wide range. Differences in the interventions might contribute to some extent to the observed heterogeneity, but they do not seem to be a major factor. In three of four subgroup analyses of single extracts there was strong heterogeneity; for one extract the $95 \%$ confidence intervals of the two available trials (Gastpar 2006; Uebelhack 2004) did not even overlap, indicating that the results are hardly compatible. However, some of the factors leading to considerable heterogeneity between study findings could be identified. Considering country of origin, precision, and baseline depression severity of included patients explained 50 to 60 percent of the variance between trial results in comparisons with placebo and 20 to 40 percent in comparison with standard antidepressants. Nevertheless, it has to be stated that meta-regression analyses are (even if a priori defined) entirely of observative nature. Findings on the association of baseline depression severity and effect size estimates may be biased through structural dependence and regression to the mean, and thus should be interpreted with caution (Higgins 2008). Furthermore, inferences drawn from a meta-regression analysis on aggregate data may differentiate from inferences drawn from a meta-regression analysis on individual data (Deeks 2006; e.g. 'ecological bias').

The finding that more precise placebo-controlled trials yielded less positive results than less precise trials could indicate publication bias (trials with positive results are more likely to be published than trials with negative results) or bias within studies (smaller trials with less rigorous methods yielding overoptimistic results). We cannot rule out, but doubt, that selective publication of overoptimistic results in small trials strongly influences our findings. There is some evidence that "negative" trials without demonstrable differences between extracts and placebo were published less often as full articles than trials with "positive" findings. Our extensive searches identified three "negative" trials that were only published as abstracts or theses. Two that were conducted in the early 1990s (these were included in earlier versions of this review Linde 1996; Linde 1998; Linde 2005a) involved patients without documented major depression (König 1993; Osterheider 1992), and one that was conducted in the late 1990s involved patients with major depression (Montgomery 2000). One positive trial included in our last update, but now excluded, was published as an abstract and as a chapter in a not widely available book (Winkel 2000). One comparably large, positive trial (Bracher 2001) has been published only in a short report as a supplement to a German medical newspaper. This trial is an example that sponsors or manufacturers of herbal medicines sometimes have very limited interest in a major publication if their trial includes a new aspect (in that case a once daily dosage), as there is no patent protection for herbal extracts and results can be exploited by competitors, too. We suspect that there are few additional relevant unpublished trials. Few manufacturers of hypericum extracts sponsor research trials, and the five manufacturers whose products were tested in most of the trials told us they had (with the exception of one smaller negative trial) no other unpublished trials that possibly met our inclusion criteria. Through personal communication we were informed that there are at least one or two unpublished negative trials on tea preparations of Hypericum. However, tea preparations are phytochemically very different from alcoholic extracts and have to be evaluated separately.

We found that the quality of the majority of trials was adequate, and we detected no systematic differences in design aspects known to be potential sources of bias. All trials were doubleblind. Though adequacy of blinding was not formally assessed in most trials, achieving similarity between hypericum and placebo preparations is not particularly difficult. All trials were randomised, and most concealed allocation assignments by using consecutively numbered identical medication containers. Reported drop-out rates were low in the majority of trials. Investigators involved in older trials may have had less training and/or experience with diagnostic standards and rating scales for depressive symptoms (Shelton 2001), but this issue, if true, is likely to affect generalisation of findings rather than internal validity. Finally, though we found no systematic differences in major factors generally related to trial quality, our subjective judgement was that larger trials tended to be of better quality than smaller trials. The dosages of standard antidepressants were (with two exceptions) within the range recommended in current guidelines (e.g., Härter 2003), but at the lower limit.

Our finding that studies from German-speaking countries yielded more favourable results than trials performed elsewhere is difficult to interpret. As our analyses are partly data-driven, they must be considered cautiously. However, the consistency and extent of the observed association suggest that there are important differences in trials performed in different countries. One possibility is that studies performed in German-speaking countries with a long history of hypericum prescription by physicians enrolled slightly different patients in spite of similar inclusion criteria. With one exception (the extremely positive trial by Uebelhack 2004 performed in a research clinic of a contract research organisation), all German studies recruited patients in private practices, while a number of trials from other countries were performed in academic research settings or hospital outpatient units. Depression with atypical or reversed vegetative features might be present more often in primary care outpatient populations (Murck 2005).The trend that trials with higher HAMD baseline values reported slightly less favourable results also suggests that effectiveness of hypericum extracts might differ between subgroups of depressive patients. While we did not systematically investigate this issue, it seems to us that the trials from countries other than Germany might be more often investigator-initiated. A closer link of trial planning, performance and analysis with manufacturer interests might influence study findings. This could result possibly in true bias, but also in conditions making a true positive outcome more likely. For example, for at least three trials (Kasper 2006; Schrader 1998; Uebelhack 2004) with large effects performed in German-speaking countries authors or sponsors reported in the publication or in personal communications that contact times and interaction with patients were limited to minimise placebo response rates. Increasing placebo group response rates due to the intensive care and monitoring in antidepressant trials are considered by some researchers as a potential reason for the problem to show specific effects (Posternak 2007). One could also speculate whether unblinding might lead German physicians (who often use hypericum extracts in their usual practice) to give more positive ratings and (the possibly more sceptic) colleagues from elsewhere to more negative ratings. However, as hypericum 
extracts have no characteristic side effects such a problem seems only relevant in comparisons with standard antidepressants.

\section{Potential biases in the review process}

The work for the first version of this review started in 1993 and three previous versions are available (Linde 1996; Linde 1998; Linde 2005a). During that period a large number of new trials became available, diagnostic classifications used for including patients into studies have changed and the quality of trials has improved. In parallel the methods of our review were adapted. The changes over time make it difficult to report our searches and their results in a consistent and transparent manner. The way how we approached authors/sponsors for obtaining missing information and the contents of inquiries were not fully systematic and have changed over time. This could imply that additional data necessary for some secondary analyses were obtained for a selected subset of studies. However, data for the main analysis were available for all or almost all trials, therefore, major biases seem highly unlikely. A potential source of bias in the responder analyses could be slightly variable responder definitions in the primary studies. Response according to the HAMD was either defined as at least $50 \%$ reduction, a HAMD score $<10$ (or 11 ) after treatment, at least one or the combination of both. Whether these definitions were truly made a priori in each study could not be assessed. Decisions on the inclusion of subgroup analyses (for example, regarding precision or country effects) for updates were driven by findings in previous versions of the review. Therefore, these analyses must be interpreted with caution. Publication and small study bias have been discussed in the previous section.

\section{AUTHORS' CONCLUSIONS}

\section{Implications for practice}

In older systematic reviews and meta-analyses of hypericum extracts (Ernst 1995; Linde 1996; Linde 1998; Kim 1999; Gaster 2000; Williams 2000) the findings of the included studies were mostly positive, but reviewers drew cautious conclusions due to methodological limitations. The quality of trials on average clearly improved over recent years. However, study findings became more often contradictory, and in the last version of our review larger trials restricted to patients with major depression showed only minimal effects over placebo (Linde 2005a). With the addition of several new, partly large trials, the cumulative evidence now suggests that hypericum extract have a modest effect over placebo in a similar range as standard antidepressants (Kirsch 2008; Turner 2008). The direct comparisons with older antidepressants and selective serotonine reuptake inhibitors seem to confirm this impression. The available clinical trials now also show that hypericum extracts have fewer side effects than both older antidepressants and selective serotonine reuptake inhibitors. This would imply that an attempt of treating mild to moderate major depression with one of the hypericum preparations positively tested in clinical trials is clearly justified. However, the differences in the findings from different countries make clear-cut recommendations difficult. The evidence for severe major depression is still insufficient to draw conclusions.

Many patients buy St John's wort products from health food stores and might not disclose this to their physicians (Smith 2004). Such uncontrolled use is problematic as serious interactions can occur with a number of frequently used drugs (Ernst 1999; Hammerness 2003; Knüppel 2004; Whitten 2006). Therefore, physicians should regularly ask their patients about hypericum intake. However, it must be kept in mind that drug interactions are not a problem unique to hypericum extracts, but also common for standard antidepressants (Nieuwstraten 2006).

It has to be emphasised that the quality of hypericum preparations can differ considerably. The composition of a product depends on the raw plant material used, the extraction process, and the solvents. In consequence, the amounts of bioactive constituents in different products can vary enormously. A recent study has shown that a number of products available on the German market contain only minor amounts of bioactive constitutents (Wurglics 2003). The hypericum extracts tested in clinical trials have to be considered high quality products. Results obtained with these extracts cannot be extrapolated directly to other products. In our meta-analysis, the type of extract did not contribute to the explanation of heterogeneity. This does not mean, however, that all products tested in the available trials are equally effective. Standardisation of a product on a defined component (for example, hyperforin or hypericin) does not resolve the problem, as currently the exact mechanism for the antidepressant effects of hypericum extracts is still unclear, and available research indicates that several components are relevant. The findings of this review most likely apply to products (using ethanol 50 to $60 \%$ or methanol $80 \%$ for extraction from dried plant material) with daily extract dosages of 500 to $1200 \mathrm{mg}$ with a ratio of raw material to extract of 3-7:1.

\section{Implications for research}

There is a clear need to investigate the reasons for the differences in findings from trials originating from German-speaking countries and those from other countries. Mulitnational trials would seem desirable, but it is unlikely that there will be funding for such studies in the near future. Individual patient data meta-analysis of existing trials could be a possible tool to investigate predictors of treatment response in a more accurate manner. The authors will try to obtain such data from researchers and/or sponsors.

\section{ACKNOWLEDGEMENTS}

The authors would like to thank

- the researchers and sponsors who provided additional information on trials

- Eva Israel and Karsten Schmidt who helped with assessing eligibility and doing extractions

- Cindy Mulrow and Matthias Egger who were involved in previous versions of the review 


\section{R E F E R E N C E S}

\section{References to studies included in this review}

Behnke 2002 \{published data only\}

Behnke K, Jensen GS, Graubaum HJ, Gruenwald J. Hypericum perforatum versus fluoxetine in the treatment of mild to moderate depression. Advances in Therapy 2002;19:43-52.

\section{Bjerkenstedt 2005 \{published data only\}}

Bjerkenstedt L, Edman GV, Alken RG, Mannel M. Hypericum extract LI 160 and fluoxetine in mild to moderate depression. A randomized, placebo-controlled multi-center study in outpatients. European Archives of Psychiatry and Clinical Neuroscience 2005;255:40-7.

\section{Bracher 2001 \{published and unpublished data\}}

Bracher A. Trial on HYP611 confirms effectiveness [HYP611Studie bestätigt Wirksamkeit]. Ärztliche Praxis 2001;51 (suppl.):3-4.

\section{Brenner 2000 \{published data only\}}

Brenner R, Azbel V, Madhusoodanan S, Pawlowska M. Comparison of an extract of hypericum (LI 160) and sertraline in the treatment of depression: a double-blind, randomized pilot study. Clinical Therapeutics 2000;22:411-9.

Brenner R, Madhusoodanan S, Pawlowska M. Efficacy of continuation treatment with hypericum perforatum in depression. Journal of Clinical Psychiatry 2002;63:455.

\section{Fava 2005 \{published data only\}}

Fava M, Alpert J, Nierenberg AA, Mischoulon D, Otto MW, Zajecka J, Murck H, Rosenbaum JF. A double-blind, randomized trial of St John's wort, fluoxetine, and placebo in major depressive disorder. Journal of Clinical Psychopharmacology 2005;25:441-7.

\section{Gastpar 2005 \{published and unpublished data\}}

Gastpar M, Singer A, Zeller K. Efficacy and tolerability of hypericum extract STW3 in long-term treatment with a oncedaily dosage in comparison with sertraline. Pharmacopsychiatry 2005;38:78-87.

\section{Gastpar 2006 \{published and unpublished data\}}

Gastpar M, Singer A, Zeller K. Comparative efficacy and safety of a once-daily dosage of hypericum extract STW3-VI and citalopram in patients with moderate depression: a doubleblind, randomised, multicentre, placebo-controlled study. Pharmacopsychiatry 2006;39:66-75.

\section{Harrer 1993 \{published and unpublished data\}}

Harrer G, Hübner WD, Podzuweit H. Effectiveness and tolerance of the hypericum extract LI 160 compared to maprotiline: a multi-center double-blind study. Journal of Geriatric Psychiatry and Neurology 1994;7(suppl 1):S24-8.

Harrer G, Hübner WD, Podzuweit H. Wirksamkeit und Verträglichkeit des Hypericum-Präparates LI 160 im Vergleich mit Maprotilin. Nervenheilkunde 1993;12:297-301.
Harrer 1999 \{published data only\}

Harrer G, Schmidt U, Kuhn U, Biller A. Comparison of equivalence between the St. John's wort extract LoHyp-57 and fluoxetine. Arzneimittel-Forschung/Drug Research 1999;49:289-96.

HDTSG 2002 \{published and unpublished data\}

* Hypericum Depression Trial Study Group. [Effect of Hypericum perforatum (St John's wort) in major depressive disorder. A randomized controlled trial]. JAMA 2002;287:1807-14.

Vitiello B, Shader RI, Parker CB, Ritz L, Harlan W, Greenblatt DJ, Gadde KM, Krishnan KRR, Davidson JRT. Hyperforim plasma level as a marker of treatment adherence in the National Institutes of Health Hypericum Depression Trial. Journal of Clin Psychopharmacology 2005;25:243-9.

Hänsgen 1996 \{published and unpublished data\}

* Hängsen KD, Vesper J. Antidepressive Wirksamkeit eines hochdosierten Hypericum-Extraktes. Muenchener medizinische Wochenschrift 1996;138(3):29-33.

Hänsgen KD, Vesper J, Ploch M. Multizentrische Doppelblindstudie zur antidepressiven Wirksamkeit des Hypericumextraktes LI 160. Nervenheilkunde 1993;12:285-9.

Vesper J, Ploch M. Multi-center double-blind study examining the antidepressant effectiveness of the hypericum extract LI 160. Journal of Geriatric Psychiatry and Neurology 1994;7(suppl 1):S15-8.

Kalb 2001 \{published data only\}

Kalb R, Trautmann-Sponsel RD, Kieser M. Efficacy and tolerability of hypericum extract WS 5572 versus placebo in mildly depressed patients. Pharmacopsychiatry 2001;34:96-103.

Kasper 2006 \{published and unpublished data\}

Kasper S, Anghelescu IG, Szegedi A, Dienel A, Kieser M. Superior efficacy of St John's wort extract WS 5570 compared to placebo in patients with major depression: a randomized, double-blind, placeb-controlled, multi-center trial [ISRCTN77277298]. BMC Medicine 2006;4:14.

\section{Laakmann 1998 \{published data only\}}

Laakmann G, Dienel A, Kieser M. Clinical significance of hyperforin for the efficacy of hypericum extracts on depressive disorders of different severities. Phytomedicine 1998;5:435-42.

Laakmann G, Schüle C, Baghai T, Kieser M. St John's wort in mild and moderate depression: the relevance of hyperforin for the clinical efficacy. Pharmacopsychiatry 1998;31 (suppl):54-9.

\section{Lecrubier 2002 \{published and unpublished data\}}

Lecrubier Y, Bech P. The Ham D6 is more homogeneous and as sensitive as the Ham D17. European Psychiatry 2007;22:252-5.

* Lecrubier Y, Clerc G, Didi R, Kieser M. Efficacy of St. John's wort extract WS 5570 in major depression: a double-blind, placebocontrolled trial. American Journal of Psychiatry 2002;159:1361-6. 
Montgomery 2000 \{published and unpublished data\}

Montgomery SA, Hübner WD, Grigoleit HG. Efficacy and tolerability of St. John's wort extract compared with placebo in patients with a mild to moderate depressive disorder. Phytomedicine 2000;7 (suppl II):107.

\section{Moreno 2005 \{published data only\}}

Moreno RA, Teng CT, de Almeida KM, Tavares H jr. Hypericum perforatum versus fluoxetine in the treatment of mild to moderate depression: a randomized double-blind trial in a Brazilian sample. Revista Brasileira de Psiquiatria 2005;28:29-32.

Philipp 1999 \{published and unpublished data\}

Philipp M, Kohnen R, Hiller KO. Hypericum extract versus imipramine or placebo in patients with moderate depression: randomized multicentre study of treatment for 8 weeks. BMJ 1999;319:1534-9.

\section{Schrader 1998 \{published and unpublished data\}}

Schrader E, Meier B, Brattström A. Hypericum treatment of mild-moderate depression in a placebo-controlled study. A prospective, double-blind, randomized, placebo-controlled, mulitcentre study. Human Psychopharmacology 1998;13:163-9.

\section{Schrader 2000 \{published and unpublished data\}}

Schrader E. Equivalence of St John's wort (Ze 117) and fluoxetine: a randomized, controlled study in mild-moderate depression. International Clinical Psychopharmacology 2001;15:61-8.

\section{Shelton 2001 \{published and unpublished data\}}

Gelenberg AJ, Shelton RC, Crits-Christoph P, Keller MB, Dunner DL, Hirschfeld RMA, Thase MAE, Russel JM, Lydiard RB, Gallop RJ, Todd L, Hellersteim DJ, Goodnick PJ, Keitner GI, Stahl SM, Halbreich U, Hopkins KS. The effectiveness of St. John's wort in major depressive disorder: a naturalistic phase 2 follow-up in which non-responders were provided alternate medication. Journal of Clinical Psychiatry 2004;65:1114-9.

* Shelton RC, Keller MB, Gelenberg A, Dunner DL, Hirschfeld R, Thase ME, et al. Effectiveness of St. John's wort in major depression. A randomized controlled trial. JAMA 2001;285:1978-86.

\section{Szegedi 2005 \{published and unpublished data\}}

Anghelescu IG, Kohnen R, Szegedi A, Klement S, Kieser M. Comparison of hypericum extract WS 5570 and paroxetine in ongoing treatment after recovery from an episode of moderate to severe depression: results from a randomized multicenter study. Pharmacopsychiatry 2006;39:213-9.

* Szegedi A, Kohnen R, Dienel A, Kieser M. Acute treatment of moderate to severe depression with hypericum extract WS 5570 (St John's wort): randomised controlled double blind noninferiority trial versus paroxetine. BMJ 2005;330:503-6.

\section{Uebelhack 2004 \{published and unpublished data\}}

Uebelhack R, Gruenwald J, Graubaum HJ, Busch R. Efficacy and tolerability of hypericum extract STW 3-VI in patients with moderate depression: a double-blind, randomized, placebocontrolled clinical trial. Advances in Therapy 2004;21:265-75.

\section{van Gurp 2002 \{published and unpublished data\}}

van Gurp G, Meterissian GB, Haiek LN, McCusker J, Bellavance F. St John's wort or sertraline? Randomized controlled trial in primary care. Canadian Family Physician 2002;48:905-12.

\section{Volz 2000 \{published data only\}}

Volz HP, Eberhardt R, Grill G. Efficacy and tolerance of the St John's wort extract D-0496 in mild to moderate depression a placebo-controlled, double-blind 6-week trial [Wirksamkeit und Verträglichkeit des Johanniskrautextraktes D-0496 bei leichten bis mittelschweren depressiven Episoden. Plazebokontrollierte Doppelblindstudie über 6 Wochen]. Nervenheilkunde 2000;19:401-5.

Vorbach 1997 \{published and unpublished data\} Vorbach EU, Arnoldt KH, Hübner WD. Efficacy and tolerability of St. John's wort extract LI 160 versus imipramine in patients with severe depressive episodes according to ICD-10. Pharmacopsychiatry 1997;30(suppl.2):81-5.

\section{Wheatley 1997 \{published and unpublished data\}}

Wheatley D. LI 160, an extract of St. John's wort, versus amitriptyline in mildly to moderately depressed outpatients - a controlled 6-week clinical trial. Pharmacopsychiatry 1997;30(suppl.2):77-80.

\section{Witte 1995 \{published and unpublished data\}}

Witte B, Harrer G, Kaptan T, Podzuweit H, Schmidt U. Behandlung depressiver Verstimmungen mit einem hochkonzentrierten Hypericumpräparat - eine multizentrische plazebokontrollierte Doppelblindstudie. Fortschritte der Medizin 1995;113:404-8.

\section{Woelk 2000 \{published data only\}}

Woelk $\mathrm{H}$ for the Remotiv/Imipramine Study Group. Comparison of St John's wort and imipramine for treating depression: randomised controlled trial. BMJ 2000;321:536-9.

\section{References to studies excluded from this review}

Agrawal 1994 \{published data only\}

Agrawal A, Dixit SP, Dubey GP, Gupta BS. Clinical evaluation of anti-depressant properties of basant (hypericum perforatum). Pharmacopsychoecologia 1994;7:253-6.

\section{Albertini 1986 \{published data only\}}

Albertini H. Evaluation d'un traitement homeopathique de la nevralgie dentaire. In: Boiron J, Belon P, Hariveau E editor(s). Recherche en homeopathie. Lyon: Fondation francaise pour la recheche en homeopathie, 1986:75-7.

\section{Bendre 1980 \{published data only\}}

Bendre VV, Dharmadhikari SD. Arnica montana and hypericum in dental practice. Hahnemann Gleanings 1980;47:70-2.

Bergmann 1993 \{published and unpublished data\}

Bergmann R, Nübner J, Demling J. Behandlung leichter bis mittelschwerer Depressionen. Therapiewoche Neurol Psychiatr 1993; 7:235-40. 


\section{Bernhadt 1993 \{published data only\}}

Bernhardt M, Liske E, Ebeling L. Hypericum perforatum in der Therapie leichter bis mittelschwerer Depressionen: Vergleich der antidepressiven Wirksamkeit von zwei unterschiedlichen Dosierungsschemata. Bonn, 5. Phytotherapie-Kongreß 1993.

\section{Brockmöller 1997 \{published data only\}}

Brockmöller J, Reum T, Bauer S, Kerb R, Hübner WD, Roots I. Hypericin and pseudohypericin: pharmacokinetics and effects on photosensitivity in humans. Pharmacopsychiatry 1997;30(suppl.2):94-101.

Czekalla 1997 \{published data only\}

Czekalla J, Gastpar M, Hübner WD, Jäger D. The effect of hypericum extract on cardiac conduction as seen in the electrocardiogram compared to that of imipramine. Pharmacopschychiatry 1997;30(supp.2):86-8.

\section{Dittmer 1992 \{published data only\}}

Dittmer TLJ. Die Behandlung von psychovegetativen Störungen mit Johanniskraut-Öl (Jukunda-Rot-Öl-Kapseln). Naturheilpraxis mit Naturmedizin 1992;45:118-22.

Ditzler 1992 \{published and unpublished data\}

Ditzler K, Gessner B, Schatton WFH, Willems M. Clinical trial on Neuropas versus placebo in patients with mild to moderate depressive symptoms: a placebo-controlled, randomised double-blind study. Complementary Therapies in Medicine 1994:2:5-13.

Ditzler K, Schatton W. Johanniskraut bei leichten bis mittelschweren Depressionen - Ergebnisse einer plazebokontrollierten Doppelblindstudie. Heilkunst 1992;104:263-70.

\section{Gu 2001 \{published data only\}}

Gu N, Li H, Shu L. Zhang H, Weng Z, Ma C, Wang M. Multicenter study of St John's wort extract in treatment of mild to moderate depression. Chinese Journal of Clinical Pharmacy 2001;10:271-4.

\section{Halama 1991 \{published and unpublished data\}}

Halama P. Wirksamkeit des Hypericum-Extraktes LI 160 bei 50 Patienten einer psychiatrischen Fachpraxis. Nervenheilkunde 1991;10:305-7.

Halama P. Wirksamkeit des Johanniskrautextraktes LI 160 bei depressiver Verstimmung. Nervenheilkunde 1991;10:250-3.

Harrer 1991 \{published and unpublished data\}

Harrer G, Schmidt U, Kuhn U. "Alternative"

Depressionsbehandlung mit einem Hypericum-Extrakt.

Therapiewoche Neurologie 1991;5:710-6.

\section{Herberg 1992 \{published data only\}}

Herberg KW. Psychotrope Phytopharmaka im Test Alternative zu synthetischen Psychopharmaka. Therapiewoche 1992;44:704-13.

\section{Hoffmann 1979 \{published data only\}}

Hoffmann J, Kühl ED. Therapie von depressiven Zuständen mit Hypericin. Zeitschrift für Allgemeinmedizin 1979;55:776-82.

\section{Hottenrott 1997 \{published data only\}}

Hottenrott K, Sommer HM, Lehrl S, Hauer H. Der Einfluss von Vitamin E und Johanniskraut-Trockenextrakt auf die Ausdauerleistungsfähigkeit von Wettkampfsportlern. Eine placebo-kontrollierte Doppelblindstudie mit Langstreckenläufern und Triathleten. Deutsche Zeitschrift für Sportmedizin 1997;48:22-7.

Häring 1996 \{published and unpublished data\}

Häring B, Hauns B, Hermann C, Hübner WD, Maier-Lenz H, Marschner N. A double-blind, placebo-controlled pilot study of LI 160 in combination with chemotherapy in patients with solid tumors. Abstracts of the 2 nd International Congress on Phytomedicine. Munich, 1996:SL-88.

Hübner 1993 \{published and unpublished data\} Hübner WD, Lande S, Podzuweit H. Behandlung larvierter Depressionen mit Johanniskraut. Nervenheilkunde 1993;12:278-280.

Hübner WD, Lande S, Podzuweit H. Hypericum treatment of mild depression with somatic symptoms. Journal of Geriatric Psychiatry and Neurology 1994;7(suppl 1):S12-5.

\section{Johnson 1992 \{published data only\}}

Johnson D. Neurophysiologische Wirkungen von Hypericum im Doppelblindversuch mit Probanden. Nervenheilkunde 1991;10:316-7.

* Johnson D, Siebenhüner G, Hofer E, Sauerwein-Giese E, Frauendorf A. Einfluß von Johanniskraut auf die ZNS-Aktivität. Neurologie und Psychiatrie 1992;6:436-44.

\section{Johnson 1993 \{published data only\}}

Johnson D, Ksciuk H, Woelk H, Sauerwein-Giese E, Frauendorf A. Effetcs of hypericum extract LI 160 compared with maprotiline on resting EEG and evoked potentials in 24 volunteers. Journal of Geriatric Psychiatry and Neurology 1994;7(suppl 1):S44-6.

Johnson D, Ksciuk H, Woelk H, Sauerwein-Giese E, Frauendorf A. Wirkungen mit Johanniskraut-Extrakt LI $160 \mathrm{im}$ Vergleich mit Maprotilin auf Ruhe-EEG und evozierte Potentiale bei 24 Probanden. Nervenheilkunde 1993;12:328-30.

\section{Kniebel 1988 \{published and unpublished data\}}

Hiller KO, Rahlfs V. Therapeutische Äquivalenz eines hochdosierten Phytopharmakons mit Amitriptylin bei ängstlichdepressiven Verstimmungen - Reanalyse einer randomisierten Studie unter besonderer Beachtung biometrischer und klinischer Aspekte. Forschende Komplementärmedizin 1995;2:123-32.

* Kniebel R, Burchard JM. Zur Therapie depressiver Verstimmungen in der Praxis. Zeitschrift für Allgemeinmedizin 1988;64:689-96.

\section{Kugler 1990a \{published data only\}}

Kugler J, Weidenhammer W, Schmidt A, Groll S. [Therapie depressiver Zustände. Hypericum-Extrakt Steigerwald als Alternative zur Benzodiazepin-Behandlung]. Zeitschrift für Allgemeinmedizin 1990;66 (suppl 1):21-9. 
Kugler 1990b \{published data only\}

Kugler J, Schmidt A, Groll S, Weidenhammer W. Zur Pharmakodynamik eines Hypericum-Extraktes. Untersuchungen bei Patienten mit depressiven Zuständen im Vergleich zu Bromazepam und Placebo. Zeitschrift für Allgemeinmedizin 1990;66(suppl.):13-20.

König 1993 \{published data only\}

König CD. Hypericum perforatum L. (gemeines Johanniskraut) als Therapeutikum bei depressiven Verstimmungszuständen eine Alternative zu synthetischen Arzneimitteln. University of Basel: Thesis, 1993.

\section{Lehrl 1993 \{published and unpublished data\}}

* Lehrl S, Woelk H. Ergebnisse von Messungen der kognitiven Leistungsfähigkeit bei Patienten unter der Therapie mit Johanniskraut. Nervenheilkunde 1993;12:281-4.

Lehrl S, Woelk H. Psychometrische Messung der Leistungkapazität unter antidepressiver Therapie mit Johanniskraut. Nervenheilkunde 1991;10:313-5.

\section{Lenoir 1999 \{published data only\}}

Lenoir S, Degenring FH, Saller R. A double-blind randomised trial to investigate three different concentrations of a standardised fresh plant extract obtained from the shoot tips of hypericum perforatum L. Phytomedicine 1999;6:141-6.

\section{Li 2005 \{published data only\}}

Li YM, Li GY, Wang XL, \& Yu LF. Rehabilitation effect of Saint John's Wort extract on depression and myocardial function after coronary artery bypass grafting: A randomized grouping, placebo-control and blind evaluation. Chinese Journal of Clinical Rehabilitation 2005;9(28):38-9.

\section{Maisenbacher 1995 \{published data only\}}

Maisenbacher J, Schmidt U, Schenk N. Therapie mit Hypericum bei Angstzuständen. Therapiewoche Neurologie Psychiatrie 1995;9:65-60.

\section{Martinez 1993 \{published data only\}}

Kasper S. Treatment of seasonal affective disorder (SAD) with hypericum extract. Pharmacopsychiatry 1997;30(suppl.2):89-93.

Martinez B, Kasper S, Ruhrmann B, Möller HJ. Hypericum in der Behandlung von saisonal abhängigen Depressionen. Nervenheilkunde 1993;12:302-7.

Martinez B, Kasper S, Ruhrmann B, Möller HJ. Hypericum in the treatment of seasonal affective disorders. Journal of Geriatric Psychiatry and Neurology 1994;7(suppl 1):S29-33.

\section{Mo 2004 \{published data only\}}

Mo WY, Yu HY, Yang Y. Comparison of Saint John' Wort extract with fluoxetine in the treatment of post-stroke depression. Chinese Journal of New Drugs 2004;13:942-4.

\section{Osterheider 1992 \{published and unpublished data\}}

Osterheider M, Schmidtke A, Beckmann H. Behandlung depressiver Syndrome mit Hypericum (Johanniskraut - eine placebokontrollierte Doppelblindstudie. Fortschritte Neurologie Psychiatrie 1992;60(suppl.2):210-1.
Panijel 1985 \{published data only\}

Panijel J. Die Behandlung mittelschwerer Angstzustände. Therapiewoche 1985;41:4659-68.

Quandt 1993 \{published and unpublished data\}

Quandt J, Schmidt U, Schenk N. Ambulante Behandlung leichter und mittelschwerer depressiver Verstimmungen. Der Allgemeinarzt 1993;15(2):97-102.

Reh 1992 \{published and unpublished data\} Reh C, Laux P, Schenk N. Hypericum-Extrakt bei Depressionen eine wirksame Alternative. Therapiewoche 1992;42:1576-81.

Schlich 1987 \{published and unpublished data\}

Schlich D, Braukmann F, Schenk N. Behandlung depressiver Zustände mit Hypericinium. Psycho 1987;13:440-7.

Schmidt 1989 \{published and unpublished data\} Schmidt U, Schenk N, Schwarz I, Vorberg G. Zur Therapie depressiver Verstimmungen. Psycho 1989;15:665-71.

Schmidt 1993 \{published and unpublished data\} Schmidt U. Konstantes Reaktionsvermögen unter antidepressiver Theerapie mit dem Hypericum-Präparat LI 160. Nervenheilkunde 1991;10:311-2.

* Schmidt U, Sommer H. Johanniskraut-Extrakt zur ambulanten Therapie der Depression. Fortschritte der Medizin 1993;111:339-42.

Schmidt 1993b \{published data only\}

Schmidt U, Harrer G, Kuhn U, Berger-Deinert W, Luther D. Wechselwirkungen von Hypericin-Extrakt mit Alkohol. Nervenheilkunde 1993;12:314-9.

Schulz 1993 \{published data only\}

Schulz H, Jobert M. Der Einfluß von Johanniskraut auf das Schlaf-EEG bei älteren Probandinnen. Nervenheilkunde 1993;12:323-7.

Schulz H, Jobert M. Effetcs of hypericum extract on the sleep EEG in older volunteers. Journal of Geriatric Psychiatry and Neurology 1994;7(suppl 1):S39-43.

\section{Sindrup 2000 \{published data only\}}

Sindrup SS, Madsen C, Bach FW, Gram LF, Jensen TS. [St. John's wort has no effect on pain in polyneuropathy]. Pain 2000;91:361-365.

\section{Sommer 1994 \{published and unpublished data\}}

Harrer G, Sommer H. Therapie leichter/mittelschwerer Depressionen mit Hypericum. Münchener medizinische Wochenschrift 1993;135:305-9.

Harrer G, Sommer H. Treatment of mild/moderate depressions with Hypericum. Phytomedicine 1994;1:3-8.

Sommer H. Besserung psychovegetativer Beschwerden durch Hypericum im Rahmen einer multizentrischen Dopppelblindstudie. Nervenheilkunde 1991;10:308-10. 
Sommer H, Harrer G. Placebo-controlled double-blind study examining the effectiveness of an hypericum preparation in 105 mildly depressed patients. Journal of Geriatric Psychiatry and Neurology 1994;7(suppl 1):S9-11.

Sommer H, Harrer G. Placebo-kontrollierte Studie zur Wirksamkeit eine Hypericumpräparates bei 105 Patienten mit Depressionen. Nervenheilkunde 1993;12:274-7.

Spielberger 1985 \{published data only\}

Spielberger E. Johanniskraut-Präparat lindert selbst mittelschwere Depressionen. Ärztliche Praxis 1985;37:2546-7.

\section{Staffeldt 1993 \{published data only\}}

Staffeldt B, Kerb R, Brockmöller J, Ploch M, Roots I. Pharmacokinetics of hypericin and pseudohypericin after oral intake of the hypericum perforatum extract LI 160 in healthy volunteers. Journal of Geriatric Psychiatry and Neurology 1994;7(suppl 1):S47-53.

Staffeldt B, Kerb R, Brockmöller J, Ploch M, Roots I. Pharmakokinetik von Hypericin und Pseudohypericin nach oraler Einnahme des Johanniskraut-Extrakts LI 160 bei gesunden Probanden. Nervenheilkunde 1993;12:331-8.

Steger 1985 \{published and unpublished data\}

Steger W. Depressive Verstimmungen. Zeitschrift für Allgemeinmedizin 1985;61:914-8.

Volz 2002 \{published data only\}

Volz HP, Murck H, Kasper S, Möller HJ. St John's wort extract (LI $160)$ in somatoform disorders: results of a placebo-controlled trial. Psychopharmacology 2002;164:294-300.

Vorbach 1994 \{published and unpublished data\}

Vorbach EU, Hübner WD, Arnoldt KH. Effectiveness and tolerance of the hypericum extract LI 160 in comparison with imipramine: randomized double-blind study in 135 outpatients. Journal of Geriatric Psychiatry and Neurology 1994;7(suppl 1):S19-23.

Vorbach EU, Hübner WD, Arnoldt KH. Wirksamkeit und Verträglichkeit des Hypericum-Extraktes LI 160 im Vergleich mit Imipramin. Nervenheilkunde 1993;12:290-6.

Warnecke 1986 \{published data only\}

Warnecke G. Beeinflussung klimakterischer Depressionen. Zeitschrift für Allgemeinmedizin 1986;62:1111-3.

Werth 1989 \{published data only\}

Werth W. Psychotonin M versus Imipramin in der Chirurgie. Der Kassenarzt 1989;15:64-8.

\section{Wienert 1991 \{published data only\}}

Wienert V, Classen R, Hiller KO. Zur Frage der Photosensibilisierung von Hypericin in einer BaldrianJohanniskraut-Kombination - klinisch-experimentelle, plazebokontrollierte Vergleichsstudie. Lübeck-Travemünde, 3rd Phytotherapy Congress 1991.
Winkel 2000 \{published data only\}

* Winkel R, Koritsch HD, Piayda H, Trenckmann. [Phytopharmakotherapie der komorbiden depressiven Störungen bei Alkoholabhängigkeit - Wirksamkeit des Johanniskrautextraktes LI 160 bei komorbid-depressiv Alkoholerkrankten]. In: Trenckmann U editor(s). Phytopharmaka und seelische Störungen. Neu-Isenburg: LinguaMed, 2000:43-51.

Winkel R, Koritsch HD, Piayda H, Trenckmann U. St. John's wort extract LI 160 in depressive, alcohol addicted patients. Phytomedicine 2000;7 (suppl II):19.

Zeller 2000 \{published data only\}

Zeller K. [Once daily administration of hypericum extract (STW 3): a convenient treatment]. In: Chrubasik S, Roufogalis BD editor(s). Herbal medicinal products for the treatment of pain. Lismore: Southern Cross University Press, 2000:164-8.

\section{Additional references}

\section{Caccia 2005}

Caccia S. Anti-depressant-like components of hypericum perforatum extracts: an overview of their pharmacokinetics and metabolism. Current Drug Metabolism 2005;6:531-43.

\section{Candy 2008}

M Candy B, Jones L, Williams R, Tookman A, King. Psychostimulants for depression. Cochrane Database of Systematic Reviews 2008, Issue 2. [DOI: 10.1002/14651858.CD006722.pub2]

\section{CGI 1970}

National Institutes of Mental Health. CGI - Clinical Global Impressions. In: Guy W editor(s). ECDEU Assessment Manual for Psychopharmacology. Rockville, MD: US Department of Heath, Education, and Welfare Public Health Service Alcohol, Drug Abuse, and Mental Health Administration, 1970:217-222.

\section{Deeks 2006}

Deeks JJ, Higgins JPT, Altman DG on behalf of the Cochrane Statistical Methods Group. Analysing and presenting results. In: Higgins JPT, Green S editor(s). Cochrane Handbook for Systematic Reviews of Interventions 4.2.6 [updated September 2006]. In: The Cochrane Library, Issue 4, 2006. Chichester: John Wiley \& Sons, Ltd, 2006.

\section{DSM-IV-TR}

American Psychiatric Association. DSM-IV-TR ${ }^{\circledR}$. http:// www.dsmivtr.org/index.cfm.

\section{Egger 1997}

Egger M, Davey Smith G, Schneider M, Minder CE. Bias in meta-analysis detected by a simple, graphical test. BMJ 1997;315:629-34.

\section{Ernst 1995}

Ernst E. St. John's wort, an anti-depressant? A systematic, criteria-based review. Phytomedicine 1995;2:67-71. 


\section{Ernst 1999}

Ernst E. Second thoughts about safety of St John's wort. Lancet 1999;354:2014-5.

\section{Gaster 2000}

Gaster B. St John's wort for depression. A systematic review. Archives of Internal Medicine 2000;160:152-6.

\section{Hamilton 1960}

Hamilton M. A rating scale for depression. Journal of Neurology, Neurosurgery and Psychiatry 1960;23:56-62.

\section{Hammerness 2003}

Hammerness P, Basch E, Ulbricht C. St. John's wort: a systematic review of adverse effects and drug interactions for the consultation psychiatrist. Psychosomatics 2003;44:271-82.

\section{Higgins 2003}

Higgins JPT, Thompson SG, Deeks JJ, Altman DG. Measuring inconsistency in meta-analyses. BMJ 2003;327:557-60.

\section{Higgins 2008}

Higgins JPT, Altman DG on behalf of the Cochrane Statistical Methods Group and the Cochrane Bias Methods Group. Chapter 8: Assessing risk of bias in included studies. In: Higgins JPT, Green S editor(s). Cochrane Handbook for Systematic Reviews of Interventions Version 5.0.0 [updated February 2008]. The Cochrane Collaboration, 2008.

\section{Härter 2003}

Härter M, Bermejo I, Schneider F, Katz S, Gaebel W, Hegerl U, Niebling W, Berger M. Clinical practice guideline for the diagnosis and treatment of depressive disorders in primary care [Versorgungsleitlinien zur Diagnostik und Therapie depressiver Störungen in der hausärztlichen Praxis]. Zeitschrift für ärztliche Fortbildung und Qualitätssicherung 2003;7 (suppl. IV):16-35.

\section{ICD-10}

World Health Organization. International Statistical Classification of Diseases and Related Health Problems, 10th Revision, Version for 2007. http://www.who.int/classifications/ apps/icd/icd10online/.

\section{ICSI 2007}

Institute for Clinical Systems Improvement (ICSI). Health care guideline: major depression in adults in primary care. www.icsi.org 2007.

\section{Jadad 1996}

Jadad AR, Moore RA, Carrol D, Jenkinson C, Reynolds DJM, Gavaghan DJ, McQuay HJ. Assessing the quality of reports of randomized clinical trials: is blinding necessary?. Controlled Clinical Trials 1996;17:1-12.

\section{Khan 2000}

Khan A, Warner HA, Brown WA. Symptom reduction and suicide risk in patients treated with placebo in antidepressant clinical trials. Archives of General Psychiatry 2000;57:311-7.

\section{Kim 1999}

Kim HL, Streltzer J, Goebert D. St John's wort for depression: a meta-analysis of well-defined clinical trials. Journal of Nerval and Mental Diseases 1999;187:532-9.

\section{Kirsch 2002}

Kirsch I, Moore TJ, Scoboria A, Nicholls SS. The emporor's new drugs: an analysis of antidepressant medication submitted to the U.S. Food and Drug Administration. Prevention \& Treatment 2002;5:article 23.

\section{Kirsch 2008}

Kirsch I, Deacon BJ, Huedo-Medina TB, Scoboria A, Moore TJ, Johnson BT. Initial severity and antidepressant benefits: a meta-analysis of data submitted to the Food and Drug Administration. PLoS Medicine 2008;5:260-8.

\section{Knüppel 2004}

Knüppel L, Linde K. Adverse effects of St. John's wort - a systematic review. Journal of Clinical Psychiatry 2004;65:1470-9.

\section{Linde 1996}

Linde K, Ramirez G, Mulrow CD, Pauls A, Weidenhammer W, Melchart D. St John's wort for depression - an overview and meta-analysis of randomized clinical trials. BMJ 1996;313:253-8.

\section{Linde 1996b}

Linde K, Worku F, Melchart D, Wiesner-Zechmeister M, Pothmann R, Weinschütz T, Melchart D. Randomized clinical trials of acupuncture for asthma - a systematic review. Forschende Komplementärmedizin 1996;3:148-55.

\section{Linde 1997}

Linde K, Clausisus N, Ramirez G, Melchart D, Eitel F, Hedges LV, Jonas WB. Are the clinical effects of homoeopathy placebo effects? A meta-analysis of placebo-controlled trials. Lancet 1997;350:834-43.

\section{Lipsey 2000}

Lipsey M, Wilson DB. Practical meta-analysis. Applied social research methods series, Vol. 49. London: Sage Publications, 2000.

\section{Montgomery 1979}

Montgomery SA, Asberg M. A new depression scale designed to be sensitive to change. British Journal of Psychiatry 1979;134:382-9.

Murck 2002

Murck H. Atypical depression and related disorders neurobiological basis for their treatment with St. John's wort [Die atypische Depression und verwandte Erkrankungen - neurobiologische Grundlagen für ihre Behandlung mit Johanniskraut-Extrakt]. Wiener medizinische Wochenschrift 2002;152:398-403.

\section{Murck 2005}

Murck H, Fava M, Alpert J, Nierenberg AA, Mischoulon D, Otto MW, Zajecka J, Mannel M, Rosenbaum JF. Hypericum extract in patients with MDD and reversed vegetative signs: re-analysis from data of a double-blind, randomized trial of 
hypericum extract, fluoxetine, and placebo. International Journal of Neuropsychopharmacology 2005;8:215-21.

\section{Nahrstedt 1997}

Nahrstedt A, Butterweck V. Biologically active and other chemical constitutents of the herb hypericum perforatum $\mathrm{L}$. Pharmacopsychiatry 1997;30(suppl 2):129-34.

\section{Nieuwstraten 2006}

Nieuwstraten C, Labiris NR, Holbrock A. Systematic overview of drug interactions with antidepressant medications. Canadian Journal of Psychiatry 2006;51:300-16.

\section{Posternak 2007}

Posternak MA, Zimmerman M. Therapeutic effect of follow-up assessments on antidepressant and placebo response rates in antidepressant effiacy trials. British Journal of Psychiatry 2007;190:287-92.

\section{Reichling 2003}

Reichling J, Hostanska K, Saller R. St. John's wort (Hypericum perforatum L.) - multicompound preparations versus single substances [Johanniskraut (Hypericum perforatum L.) Vielstoffgemische kontra phytogene Einzelstoffe]. Forschende Komplementärmedizin und Klassische Naturheilkunde 2003;10 (suppl 1):28-32.

\section{Smith 2004}

Smith L, Ernst E, Ewings P, Myers P, Smith C. Co-ingestion of herbal medicines and warfarin. British Journal of General Practice 2004;54:439-41.

\section{Sterne 2001}

Sterne JA, Egger M, Davey Smith G. Systematic reviews in health care: investigating and dealing with publication and other biases in meta-analysis. BMJ 2001;323:101-5.

\section{Thompson 1999}

Thompson SD, Sharp SJ. Explaining heterogeneity in metaanalyses: a comparison of methods. Statitics in Medicine 1999;18:2693-708.

\section{Turner 2008}

Turner EH, Matthews MM, Linardatos E, Tell RA, Rosenthal R. Selective publication of antidepressant trials and its influence on apparent efficacy. New England Journal of Medicine 2008;358:252-60.

\section{Ustun 2004}

Ustun TB, Ayuso-Mateos JL, Chatterji S, Mathers C, Murrary CJ. Global burden of depressive disorders in the year 2000. British Journal of Psychiatry 2004;184:386-92.

\section{Volz 1997}

Volz HP. Controlled clinical trials of hypericum extract in depressed patients - an overview. Pharmacopsychiatry 1997;30(suppl 2):72-6.

\section{von Zerssen 1996}

von Zerssen D. D-S. In: AMDP, CIPS editor(s). Rating scales for psychiatry. Weinheim: Beltz Test, 1990:section 2.8.

\section{Wheatley 1998}

Wheatley D. Hypericum extract - potential in the treatment of depression. CNS Drugs 1998;9:431-440.

\section{Whitten 2006}

Whitten DL, Myers SP, Hawrelak JA, Wohlmuth H. The effect of St John's wort extracts on CYP3A: a systematic review of prospective clinical trials. British Journal of Clinical Pharmacology 2006;62:512-26.

\section{Williams 2000}

Williams JW jr, Mulrow CD, Chiquette E, Hitchcock NP, Aguilar C, Cornell J. A systmatic review of newer pharmacotherapies for depression in adults: evidence report summary. Annals of Internal Medicine 2000;132:743-56.

\section{Wilson 2002}

Wilson DB. SPSS, Stata, and SAS macros for performing metaanalytic analyses. http://mason.gmu.edu/ dwilsonb/ma.html. last uptated: 15-1-2002. accessed: 10-11-2003.

\section{Wurglics 2003}

Wurglics M, Schulte-Löbbert S, Dingermann T, SchubertZsilavecs M. Rational and traditional hypericum preparations [Rationale und traditionelle Johanniskraut-Präparate]. Deutsche Apotheker Zeitung 2003;143:1454-8.

\section{Wurglics 2006}

Wurglics M, Schubert-Zsilavecz M. Hypericum perforatum: a "modern" herbal antidepresant: pharmacokinetics of active ingredients. Clinical Pharmacokinetics 2006;45:449-68.

\section{References to other published versions of this review \\ Linde 1998}

Linde K, Mulrow CD. St John's wort for depression. Cochrane Database of Systematic Reviews 1998, Issue 4.

\section{Linde 2005a}

Linde K, Mulrow CD, Berner M, Egger M. St John's wort for depression. Cochrane Database of Systematic Reviews 2005, Issue 2.

\section{Linde 2005b}

Linde K, Berner M, Egger M, Culrow C. St John's wort for depression - meta-analysis of randomised controlled trials. British Journal of Psychiatry 2005;186:99-107.

* Indicates the major publication for the study 
CHARACTERISTICS OF STUDIES

Characteristics of included studies [ordered by study ID]

Behnke 2002

Concealment: unclear
Blinding: double-blind
Drop-outs/withdrawals: 6 of 35 in hypericum group, 3 of 35 in fluoxetine group
Jadad score: $1-1-1$
IV score: $1-0-1-0.5-0.5-0.5$

$\begin{array}{ll}\text { Participants } & \text { Number of patients included/analyzed: } 70 / 61 \\ & \text { Demographics: } 47 \text { female, mean age } 51 \text { (treatment group) and } 48 \text { (control group) } \\ & \text { Diagnosis: mild to modedrate depression (ICD 10 F32.0 and 32.1) } \\ \text { Setting: multicenter trial from Denmark } & \text { Baseline: HAMD score treatment group 20.0 +/- 3.2, control group 20.7 +/- } 2.9\end{array}$

Interventions Treatment: Hypericum extract (Calmigen) 2x1 coated tablet daily (300 mg extract) for 6 weeks Control: Fluoxetine $2 \times 20 \mathrm{mg}$ for 6 weeks

$\begin{array}{ll}\text { Outcomes } & \text { Observation period: } 6 \text { weeks } \\ & \text { Physician-rated: Hamilton Depression Scale (HAMD, } 17 \text { items; response = at least 50\% reduction), Clini- } \\ & \text { cal Global Impression Index (CGI) } \\ & \text { Patient-rated: von Zerssen Depression Scale, Clinical Global Impression Index (CGI), global assessment }\end{array}$

Notes Contract research organization which performed the study contacted for additional information but no answer was received

\begin{tabular}{lll}
\hline Risk of bias & \\
\hline Bias & Authors' judgement & Support for judgement \\
\hline Allocation concealment? & Unclear risk & B - Unclear \\
\hline
\end{tabular}

\section{Bjerkenstedt 2005}

\begin{tabular}{|c|c|}
\hline Methods & $\begin{array}{l}\text { Concealment: consecutively numbered pharmacy } \\
\text { Blinding: double-blind (double-dummy) } \\
\text { Drop-outs/withdrawals: ITT analysis on } 163 \text { of } 174 \text { patients randomized } \\
\text { Jadad score: } 1-2-0 \\
\text { IV score: } 1-1-1-0.5-0.5-0.5\end{array}$ \\
\hline Participants & $\begin{array}{l}\text { Number of patients included/analyzed: } 177 \text { /163 } \\
\text { Demographics: } 129 \text { female, mean age } 50 \text { years } \\
\text { Diagnosis: mild to moderate major depression (DSM-IV 296.31 or 32) } \\
\text { Setting: } 15 \text { practices (psychiatry, neurology, GP) in Sweden } \\
\text { Baseline: HAMD score hypericum group 24.9, fluoxetine group 23.8, placebo group } 25.2\end{array}$ \\
\hline Interventions & $\begin{array}{l}\text { Treatment: Hypericum extract LI } 160 \text { (Jarsin } 300) 3 \times 1 \text { coated table }(900 \mathrm{mg}) \text { for } 6 \text { weeks Control 1: Flu- } \\
\text { oxetine } 1 \times 1 \text { capsule }(20 \mathrm{mg} \text { ) for } 6 \text { weeks } \\
\text { Control 2: Placebo for } 4 \text { weeks, then randomized to hypericum or fluoxetine }\end{array}$ \\
\hline Outcomes & $\begin{array}{l}\text { Observation period: } 6 \text { weeks } \\
\text { Physician-rated: Hamilton Depression Scale (HAMD), Montgomery Asberg Depression Rating Scale } \\
\text { (MADRS), Clinical Global Impression Index (CGI) }\end{array}$ \\
\hline
\end{tabular}


Bjerkenstedt 2005 (Continued)

Notes

Due to the request of the ethical review board patients allocated to placebo had to be re-randomized to hypericum or fluoxetine after 4 weeks. Prioir to publication of the main reference authors provided some additional information; after publication of the full report no further unpublished information was considered necessary

\section{Risk of bias}

\begin{tabular}{lll}
\hline Bias & Authors' judgement & Support for judgement \\
\hline Allocation concealment? & Low risk & A - Adequate \\
\hline
\end{tabular}

\section{Bracher 2001}

\begin{tabular}{ll}
\hline Methods & Concealment: consecutively numbered pharmacy \\
& Blinding: double-blind \\
& Drop-outs/withdrawals: ITT analysis on 207 of 218 patients randomized \\
Jadad score: not performed (see notes) \\
IV score: not performed (see notes)
\end{tabular}

$\begin{array}{ll}\text { Participants } & \text { Number of patients included/analyzed: } 218 / 207 \\ & \text { Demographics: } 167 \text { female, mean age } 44 \text { years } \\ & \text { Diagnosis: mild to moderate major depression (DSM-IV 296.31 or 32) } \\ & \text { Setting: } 17 \text { practices (GP, various other) in Germany } \\ & \text { Baseline: HAMD score hypericum group 19.7, placebo group } 19.7\end{array}$

\begin{tabular}{ll}
\hline Interventions & Treatment: Hypericum extract HYP611 (Felis 650) $1 \times 1$ coated table (650 mg) for 6 weeks \\
Control: Placebo
\end{tabular}
Control: Placebo

Observation period: 6 weeks
Physician-rated: Hamilton Depression Scale (HAMD), Montgomery Asberg Depression Rating Scale
(MADRS), Clinical Global Impression Index (CGI)
Patient-rated: von Zerssen Paranoid Depression Scale (PDS)

Notes

This trial was identified during the revision process. It is only published as a short report in a sponsored supplement to a nonscientific journal. The sponsor (Hexal AG, Holzkirchen, Germany) allowed a reviewer (KL) to extract detailed information from the full unpublished study report

\section{Risk of bias}

\begin{tabular}{lll}
\hline Bias & Authors' judgement & Support for judgement \\
\hline Allocation concealment? & Low risk & A - adequate \\
\hline
\end{tabular}

\section{Brenner 2000}

\begin{tabular}{ll}
\hline Methods & Concealment: unclear \\
& Blinding: double-blind (double-dummy) \\
& Drop-outs/withdrawals: 7 of 15 hypericum patients, 3 of 15 sertraline patients \\
& Jadad score: $1-2-0$ \\
& IV score: $1-0-1-1-1-0$ \\
\hline Participants & Number of patients included/analyzed: $30 / 28$ \\
& Demographics: 19 female, mean age 45 years \\
& Diagnosis: mild to moderate depressive disorder
\end{tabular}


Brenner 2000 (Continued)

Setting: community hospital in USA

Baseline: HAMD score hypericum group $21.3+$ +- 3.2, sertraline group $21.7+$ +- 2.7

\begin{tabular}{ll}
\hline Interventions & $\begin{array}{l}\text { Treatment: Hypericum extract LI } 1603 \times 1 \text { tablet (900 mg extract) for } 7 \text { weeks } \\
\text { Control: Sertraline } 3 \times 1 \text { capsule }(75 \mathrm{mg}) \text { for } 7 \text { weeks }\end{array}$ \\
\hline Outcomes & $\begin{array}{l}\text { Observation period: } 7 \text { weeks } \\
\text { Physician-rated: Hamilton Depression Scale (HAMD, } 17 \text { items; response = at least 50\% reduction), Clini- } \\
\text { cal Global Impression Index (CGI) } \\
\text { Patient-rated: von Zerssen Depression Scale (D-S) }\end{array}$ \\
\hline Notes & $\begin{array}{l}\text { Small study. High drop-out rate with more losses in the hypericum group. In spite of intention to treat } \\
\text { analysis bias cannot be ruled out }\end{array}$ \\
\hline Risk of bias & Authors' judgement Support for judgement \\
\hline Bias & Unclear risk $\quad$ B - Unclear \\
\hline
\end{tabular}

Fava 2005

Concealment: unclear
Blinding: double-blind
Drop-outs/withdrawals: $18 / 45$ in the hypericum group, 23 of 47 in the fluoxetine group and 22 of 43 in
the placebo group
Jadad score: $1-1-0$
IV score: $1-0-1-0.5-0.5-0$

\begin{tabular}{|c|c|}
\hline Participants & $\begin{array}{l}\text { Number of patients included/analyzed: } 135 / 135 \\
\text { Demographics: } 57 \% \text { female, mean age } 37 \text { years } \\
\text { Diagnosis: mild to moderate major depression } \\
\text { Setting: } 2 \text { psychiatric outpatient departments in the US } \\
\text { Baseline: HAMD score (17 items) } 19.6+/-3.5 \text { in the hypericum group, } 19.9+/-2.9 \text { in the fluoxetine and } \\
19.6+/-3.1 \text { in the placebo group }\end{array}$ \\
\hline Interventions & $\begin{array}{l}\text { Treatment: Hypericum extract LI } 1603 \times 1 \text { tablets }(900 \mathrm{mg}) \text { for } 12 \text { weeks (+ } 1 \text { capsule placebo) } \\
\text { Control 1: Fluoxetine } 1 \times 20 \mathrm{mg} \text { (capsule) for } 12 \text { weeks }(+3 \times 1 \text { placebo tablets) } \\
\text { Control 2: Placebo ( } 1 \times 1 \text { capsule, } 3 \times 1 \text { tablets) }\end{array}$ \\
\hline Outcomes & $\begin{array}{l}\text { Observation period: } 12 \text { weeks (+ } 1 \text { week placebo run-in) } \\
\text { Physician-rated: Hamilton Depression Scale (HAMD, } 17 \text { items; response = at least } 50 \% \text { reduction), Clini- } \\
\text { cal Global Impression Index (CGI) } \\
\text { Patient-rated: Beck Depression Inventory (BDI) }\end{array}$ \\
\hline Notes & $\begin{array}{l}\text { High drop-out rate (intent to treat analysis); recruitment stopped before planned sample size was } \\
\text { reached due to decision of the sponsor (lichtwer Pharma, Berlin). Only remission rates reported (and } \\
\text { use instead of responder data for analyses) }\end{array}$ \\
\hline \multicolumn{2}{|l|}{ Risk of bias } \\
\hline Bias & Authors' judgement Support for judgement \\
\hline Allocation concealment? & Unclear risk \\
\hline
\end{tabular}


Gastpar 2005

\begin{tabular}{|c|c|}
\hline Methods & $\begin{array}{l}\text { Concealment: numbered pharmacy } \\
\text { Blinding: double-blind (double-dummy technique) } \\
\text { Drop-out/withdrawals } 17 \text { of } 123 \text { (hypericum), } 19 \text { of } 118 \text { (sertaline) } \\
\text { Jadad score: } 2-2-1 \\
\text { IV score: } 1-1-1-0.5-0.5-0.5\end{array}$ \\
\hline Participants & $\begin{array}{l}\text { Patients included/analyzed: } 241 / 118 \text { (in per protocol analysis) } \\
\text { Demographics: } 74 \% \text { female, mean age } 19 \text { years } \\
\text { Diagnosis: moderate depression (F32.1 or F33.1) } \\
\text { Setting: } 18 \text { primary care physicians in Germany } \\
\text { Baseline: HAMD values } 22.0+/-1.1 \text { vs. } 22.1+/-1.1\end{array}$ \\
\hline Interventions & $\begin{array}{l}\text { Interventions: Hypericum extract STW3 } 1 \times 1 \text { tablet ( } 612 \mathrm{mg} \text { extract) }+1 \text { capsule placebo daily for } 12 \\
\text { weeks } \\
\text { Control: } 1 \times 1 \text { tablet sertraline }(50 \mathrm{mg})+1 \text { tablet placebo daily for } 12 \text { weeks } \\
\text { After the } 12 \text { week-treatment phase there was an optional continuation phase }\end{array}$ \\
\hline Outcomes & $\begin{array}{l}\text { Observation period: } 12 \text { weeks for the main comparison }+12 \text { weeks continuation phase } \\
\text { Physician-rated: Hamitlon Depression Scale (HAMD, } 17 \text { items; response }=\text { HAMD score }<10 \text { or at least } \\
50 \% \text { reduction), Clinical Global Impression Index (CGI) } \\
\text { Patient-rated: Adjective Mood Scale (BfS) }\end{array}$ \\
\hline Notes & $\begin{array}{l}\text { Additional information provided by first author and sponsor. } \\
\text { The number of adverse effects in the hypericum group is much higher than in the sertraline group (189 } \\
\text { vs. 112). For the number of patients reporting adverse effects the difference is less pronounced ( } 74 \text { vs. } \\
60 ; 1 \text { patient in the hypericum gorup had reported } 26 \text { adverse effects). In the hypericum group there } \\
\text { was a higher number of infections ( } 48 \text { vs. } 26 \text {; not observed in any other trial before). The number of ad- } \\
\text { verse effects which were possibly causally related with the treatment was higher in the sertraline group } \\
\text { (12 vs. 16). Also the intensity of side effects was more pronounced in the sertraline group. }\end{array}$ \\
\hline \multicolumn{2}{|l|}{ Risk of bias } \\
\hline Bias & Authors' judgement Support for judgement \\
\hline Allocation concealment? & A - Adequate \\
\hline
\end{tabular}

\section{Gastpar 2006}

\begin{tabular}{|c|c|}
\hline Methods & $\begin{array}{l}\text { Concealment: numbered pharmacy } \\
\text { Blinding: double-blind (double-dummy technique) } \\
\text { Drop-outs/withdrawals: } 6 \text { of } 131 \text { (hypericum), } 6 \text { of } 127 \text { (citalopram), } 8 \text { of } 130 \text { (placebo) } \\
\text { Jadad score: } 2-2-1 \\
\text { IV score: } 1-1-1-0.5-0.5-1\end{array}$ \\
\hline Participants & $\begin{array}{l}\text { Patients included/analyzed: } 388 / 388 \\
\text { Demographics: } 67 \% \text { female, mean age } 50 \text { years } \\
\text { Diagnosis: moderate depression (ICD-10 F32.1 or F33.1) } \\
\text { Setting: } 21 \text { general practitioners and internists in Germany } \\
\text { Baseline: HAMD score hypericum group } 21.9+/-1.2 \text {, citalopram group } 21.8+/-1.2 \text {, placebo group } 22.0 \\
+/-1.2\end{array}$ \\
\hline Interventions & $\begin{array}{l}\text { Treatment: Hypericum extract STW3-VI } 1 \times 1 \text { tablet ( } 900 \mathrm{mg} \text { extract) for } 6 \text { weeks } \\
\text { Control 1: Placebo for } 6 \text { weeks } \\
\text { Control 2: Citalopram } 1 \times 1 \text { tablet } 20 \mathrm{mg} \text { for } 6 \text { weeks }\end{array}$ \\
\hline
\end{tabular}


Gastpar 2006 (Continued)

Outcomes
Observation period: 6 weeks

Physician-rated: Hamitlon Depression Scale (HAMD, 17 items; response $=$ HAMD score $<10$ or at least $50 \%$ reduction), Clinical Global Impression Index (CGI)

Patient-rated: Adjective Mood Scale (BfS)

Notes Additional information provided by first author and sponsor

\section{Risk of bias}

\begin{tabular}{lll}
\hline Bias & Authors' judgement & Support for judgement \\
\hline Allocation concealment? & Low risk & A - Adequate \\
\hline
\end{tabular}

Harrer 1993

Concealment: consecutively numbered pharmacy
Blinding: Double-blind
Drop-outs/withdrawals: 7 of 51 in hypericum group, 9 of 51 in maprotiline group
Jadad score: $2-2-1$
IV score: $1-1-1-0.5-0.5-0.5$

Pumber of patients included/analyzed: $102 / 86$
Demographics: 73 female, mean age 44 years in the Hypericum group and 48 years in the maprotiline
group
Diagnosis: single, moderately severe depressive episode (ICD 10 F32.1) (according to information from
the sponsor patients met DSM-III-R criteria for major depression); Setting: 6 practices in Germany (neu-
rology/psychiatry)
Baseline: HAMD scores $20.5+/-3.7$ in hypericum group and $21.5+/-3.9$ in maprotiline group

Interventions

Treatment: Hypericum extract LI 160 (Jarsin 300) 3x1 coated tablet (900 mg extract) daily for 4 weeks Control: Maprotiline $3 \times 1$ coated tablet $(75 \mathrm{mg})$ daily for 4 weeks

Outcomes Observation period 4 weeks

Physician-rated: Hamilton Depression Scale (HAMD, 17 items; response $=$ at least $50 \%$ reduction or score < 10), Clinical Global Impression Index (CGI), global assessment

Patient rated: Depression Scale von Zerssen D-S, global assessment

Notes Additional information provided from sponsor (Lichtwer, Berlin, Germany)

\section{Risk of bias}

\begin{tabular}{lll}
\hline Bias & Authors' judgement & Support for judgement \\
\hline Allocation concealment? & Low risk & A - Adequate \\
\hline
\end{tabular}

Harrer 1999

\begin{tabular}{ll}
\hline Methods & Concealment: unclear \\
& Blinding: double-blinding \\
& Drop-outs/withsdrawals: 8 of 77 hypericum patients and 16 of 84 fluoxetine patients \\
& Jadad score: $1-1-1$ \\
& IV score: $1-0-1-0.5-0.5-0.5$
\end{tabular}

Participants Number of patients included/analyzed: 161/149

St John's wort for major depression (Review) 
Harrer 1999 (Continued)

Demographics: 129 female, mean age 69 years

Diagnosis: mild to moderate depression (ICD 10 F32.0 or F32.1)

Setting: 17 practices in Germany

Baseline: HAMD score hypericum group 16.6, fluoxetine group 17.2

Treatment: Hypericum extract LoHyp-57 $2 \times 2$ coated tablets $(800 \mathrm{mg})$ for 6 weeks
Control: Fluoxetine $2 \times 2$ coated tablets $(20 \mathrm{mg})$ for 6 weeks

$\begin{array}{ll}\text { Outcomes } & \text { Observation period: } 6 \text { weeks } \\ & \text { Physcian-rated: Hamilton Depression Scale (HAMD, } 17 \text { items; response = at least 50\% reduction or } \\ & \text { score }<11 \text { ), Clinical Global Impression Index (CGI) } \\ & \text { Patient-rated: Self-Rating Scale for Depression (SDS), Fragebogen Alltagsleben (German quality of life } \\ & \text { questionnaire) }\end{array}$

Notes Reporting of results partly insufficient

\section{Risk of bias}

\begin{tabular}{lll}
\hline Bias & Authors' judgement & Support for judgement \\
\hline Allocation concealment? & Unclear risk & B - Unclear \\
\hline
\end{tabular}

\section{HDTSG 2002}

\begin{tabular}{ll}
\hline Methods & Concealment: central telephone randomization \\
& Blinding: double-blind (double-dummy) \\
& Drop-outs/withdrawals: 31 of 113 in hypericum group, 32 of 116 in placebo group, and 32 of 111 in ser- \\
& traline group \\
& Jadad score: $2-2-1$ \\
& IV score: $1-1-1-0.5-0.5-0.5$
\end{tabular}

$\begin{array}{ll}\text { Participants } & \text { Number of patients included/analyzed: } 340 / 340 \\ & \text { Demographics: } 66 \% \text { female, mean age } 43 \text { years } \\ & \text { Diagnosis: major depression (DSM-IV) } \\ & \text { Setting: } 12 \text { academic and community psychiatric research clinics in the US } \\ & \text { Baseline: HAMD scores } 23.1+/-2.7 \text { (hypericum), } 22.7+/-2.7 \text { (placebo), } 22.5+/-2.5 \text { (sertraline) }\end{array}$

$\begin{array}{ll}\text { Interventions } & \text { Treatment: Hypericum LI } 160 \text { extract } 900 \text { to } 1500 \mathrm{mg} \text { for } 8 \text { weeks } \\ \text { Control 1: Placebo for } 8 \text { weeks } \\ \text { Control 2: Sertraline } 50 \text { to } 100 \mathrm{mg} \text { for } 8 \text { weeks }\end{array}$

$\begin{array}{ll}\text { Outcomes } & \text { Observation period: } 1 \text { weeks run-in, } 8 \text { weeks treatment, } 18 \text { weeks follow-up for responders } \\ & \text { Physician-rated: Hamilton Depression Scale (HAMD, response = at least 50\% reduction or score < 10), } \\ \text { Clinical Global Impression Index (CGI), Global Assessment of Functioning (GAF) } \\ \text { Patient-rated: Beck Depression Inventory (BDI), Sheehan Disability Scale (SDS) }\end{array}$

Notes Trial funded by public institution (NIH). Large proportion of patients with chronic depression. Some unblinding detected (sole trial which reported a check of blinding). Authors provided additional data

\section{Risk of bias}

\begin{tabular}{lll}
\hline Bias & Authors' judgement & Support for judgement \\
\hline Allocation concealment? & Low risk & A - Adequate \\
\hline
\end{tabular}


Hänsgen 1996

\begin{tabular}{|c|c|c|}
\hline Methods & \multicolumn{2}{|c|}{$\begin{array}{l}\text { Concealment: numbered pharmacy } \\
\text { Blinding: double-blind } \\
\text { Drop-outs/withdrawals: } 3 \text { of } 54 \text { in hypericum group, } 4 \text { of } 54 \text { in placebo group } \\
\text { Jadad score: } 2-2-1 \\
\text { IV score: } 1-1-1-1-1-0.5\end{array}$} \\
\hline Participants & \multicolumn{2}{|c|}{$\begin{array}{l}\text { Number of patients included/analyzed: } 108 / 101 \\
\text { Demographics: } 66 \text { female, mean age } 52 \text { years } \\
\text { Diagnosis: major depression (DSM-III-R, HAMD score > 15) } \\
\text { Setting: } 17 \text { practices in Germany (neurologists/psychiatrist, general practitioners) } \\
\text { Baseline: HAMD score } 21.8+/-2.8 \text { (hypericum), } 20.4+/-3.4 \text { (placebo) }\end{array}$} \\
\hline Interventions & \multicolumn{2}{|c|}{$\begin{array}{l}\text { Treatment: Hypericum extract LI160 (Jarsin 300) 3x1 coated tablet daily ( } 900 \text { mg extract) for } 4 \text { weeks } \\
\text { Control: Placebo } \\
\text { For further } 2 \text { weeks both groups received Hypericum }\end{array}$} \\
\hline Outcomes & \multicolumn{2}{|c|}{$\begin{array}{l}\text { Observation period: } 4 \text { weeks } \\
\text { Physician-rated: Hamilton Depression Scale (HAMD, } 21 \text { items; response = at least 50\% reduction or } \\
\text { score < 10), Clinical Global Impression Index (CGI) after } 2 \text { and } 4 \text { weeks } \\
\text { Patient-rated: Depression Scale von Zerssen (D-S), complaints check list (BEB) after } 2 \text { and } 4 \text { weeks }\end{array}$} \\
\hline Notes & \multicolumn{2}{|c|}{$\begin{array}{l}\text { Additional information provided by author and sponsor (Lichtwer, Berlin, Germany). This trial was first } \\
\text { published in } 1993 \text { (in German, } 1994 \text { in English) with } 72 \text { patients and re-published with } 108 \text { patients in } \\
1996 \text { (without refering to the earlier publications) }\end{array}$} \\
\hline \multicolumn{3}{|l|}{ Risk of bias } \\
\hline Bias & Authors' judgement & Support for judgement \\
\hline Allocation concealment? & Low risk & A-Adequate \\
\hline
\end{tabular}

Kalb 2001

$\begin{array}{ll}\text { Methods } & \text { Concealment: numbered pharmacy } \\ & \text { Blinding: double-blind } \\ & \text { Drop-outs/withdrawals: none } \\ & \text { Jadad score: } 2-2-1 \\ & \text { IV score: } 1-1-1-1-1\end{array}$

Participants Patients included/analyzed: $72 / 72$

Demographics: 48 female, mean age 48 years

Diagnosis: mild to moderate depression (DSM-IV 296.21/31/22/32)

Setting: 11 practices (psychiatry, internal medicine, GP) in Germany

Baseline: HAMD score $19.7+$ - 3.4 hpyericum group, $20.1+/$ - 2.6 placebo group

Treatment: Hypericum extract WS 5572 (Neuroplant) $3 \times 1$ coated tablet (900 mg) for 6 weeks
Control: Placebo for 6 weeks

Outcomes Observation period: 3-7 days run-in, 6 weeks treatment

Physician-rated: Hamilton Depression Scale (HAMD, 17 items; response = at least 50\% reduction), Clinical Global Impression Index (CGI)

Patient-rated: von Zerssen Depression Scale (D-S), Patient's Global Assessment Scale (GPA) 
Kalb 2001 (Continued)

\section{Risk of bias}

\begin{tabular}{lll}
\hline Bias & Authors' judgement & Support for judgement \\
\hline Allocation concealment? & Low risk & A - Adequate \\
\hline
\end{tabular}

\section{Kasper 2006}

Concealment: numbered pharmacy
Blinding: double-blind
Drop-out/withdrawals: 12 of 123 (hypericum $600 \mathrm{mg}$ ), 19 of 127 (hypericum $1200 \mathrm{mg}$ ), 8 of 82 (placebo)
Jadad score: $2-2-1$
IV score: $1-1-0.5-1-1-1$

Participants
Demographics: $63 \%$ female, mean age 46 years
Diagnosis: mild or moderate, single or recurrent, major depressive episode (DSM IV 296.21/22,
296.31/32)
Setting: 11 psychiatric and 5 GP practices in Germany
Baseline: HAMD score hypericum 600 mg group $22.8+/-3.3$, hypericum $1200 \mathrm{mg}$ group $22.6+/-3.8$,
placebo group $23.6+/-4.2$

\begin{tabular}{ll}
\hline Interventions & Treatment 1: 1 tablet hypericum extract $(600 \mathrm{mg}$ ) daily +1 placebo tablet for 6 weeks \\
& Treatment 2: $2 \times 1$ tablet hypericum extract (total daily extract dosage $1200 \mathrm{mg})$ daily for 6 weeks \\
Control: $2 \times 1$ tablet placebo daily for 6 weeks
\end{tabular}

\begin{tabular}{ll}
\hline Outcomes & Observation period: 6 weeks \\
& Physician-rated: Hamilton depression Scale (HAMD, 17 items; response = atleast 50\% score reduction), \\
& Clinical Global Impression Index (CGI), Montgomery-Asberg Depression Scale (MADRS) \\
& Patient-rated: Beck Depression Inventory (BDI), qualtiy of life (SF-36)
\end{tabular}

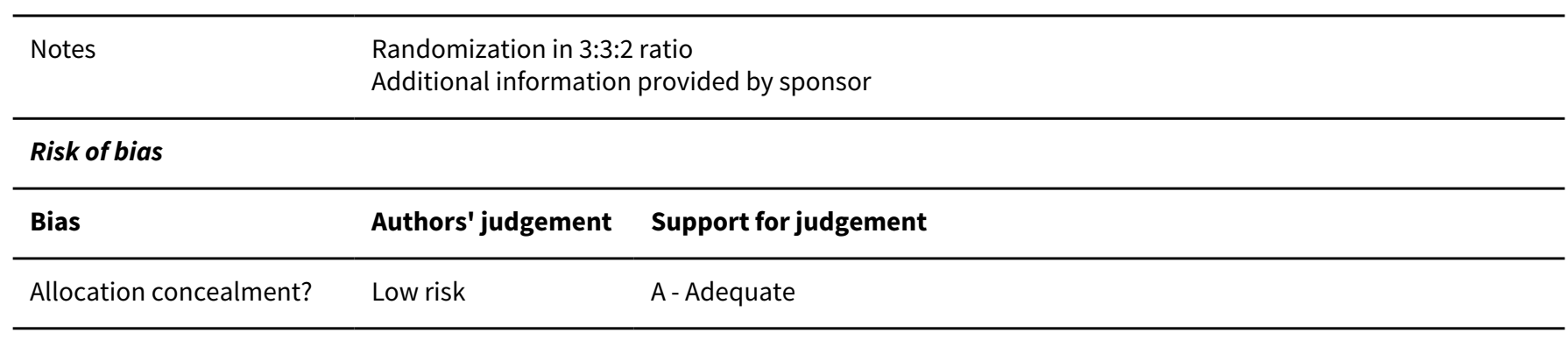

\section{Laakmann 1998}

\begin{tabular}{ll}
\hline Methods & Concealment: unclear \\
& Blinding: double-blind \\
& Drop-outs/withdrawals: 3 in group hypericum 1, 1 in group hypericum 2, 4 in placebo group \\
Jadad score: $2-2-1$ \\
IV score: $1-0-1-1-1-1$ \\
\hline
\end{tabular}

\footnotetext{
Participants
}

Patients included/analyzed: 147/147

Demographics: 117 female, mean age 49 years

Diagnosis: mild to moderate depression (DSM-IV)

Setting: 11 practices in Germany

Baseline: HAMD score 20.9 +/- 3.1 (hypericum 1), $20.3+/-2.7$ (hypericum 2), $21.2+/-3.3$ (placebo) 
Laakmann 1998 (Continued)

Interventions

Treatment 1: Hypericum extract WS 5572 (5\% hyperforin) 3x1 coated tablet $(900 \mathrm{mg}$ ) for 6 weeks

Treatment 2: Hypericum extract WS 5573 (0.5\% hyperforin) 3x1 coated tablet $(900 \mathrm{mg})$ for 6 weeks Control: Placebo for 6 weeks
Observation period: 6 weeks

Physician-rated: Hamilton Depression Scale (HAMD, 17 items; response $=$ at least $50 \%$ reduction), Clinical Global Impression Index (CGI)

Patient-rated: von Zerssen Depression Scale (D-S), global assessment

Notes Includes a group receiving a second hypericum extract with very low hyperforin content (not included in meta-analysis as this tests an extract which was not marketed)

\section{Risk of bias}

\begin{tabular}{lll}
\hline Bias & Authors' judgement & Support for judgement \\
\hline Allocation concealment? & Low risk & A - Adequate \\
\hline
\end{tabular}

\section{Lecrubier 2002}

\begin{tabular}{|c|c|c|}
\hline Methods & \multicolumn{2}{|c|}{$\begin{array}{l}\text { Concealment: numbered pharmacy } \\
\text { Blinding: double-blind } \\
\text { Drop-outs/withdrawals: } 18 \text { of } 186 \text { (hypericum), } 25 \text { of } 189 \text { placebo) } \\
\text { Jadad score: } 1-2-0 \\
\text { IV score: } 1-0-1-1-1-0.5\end{array}$} \\
\hline Participants & \multicolumn{2}{|c|}{$\begin{array}{l}\text { Patients included/analyzed: } 375 / 375 \\
\text { Demographics: } 297 \text { female, mean age } 41 \text { years } \\
\text { Diagnosis: mild to moderate depression (DSM-IV 296.21/22/31/32) } \\
\text { Setting: } 26 \text { psychiatric centers and practices in France } \\
\text { Baseline: HAMD score hypericum group } 21.9+/-1.7 \text {, placebo group } 21.9+/-1.7\end{array}$} \\
\hline Interventions & \multicolumn{2}{|c|}{$\begin{array}{l}\text { Treatment: Hypericum extract WS } 55703 \times 1 \text { tablet }(900 \mathrm{mg}) \text { for } 6 \text { weeks } \\
\text { Control: placebo for } 6 \text { weeks }\end{array}$} \\
\hline Outcomes & \multicolumn{2}{|c|}{$\begin{array}{l}\text { Observation period: } 3-7 \text { days run-in, } 6 \text { weeks treatment } \\
\text { Physician-rated: Hamilton Depression Scale (HAMD, } 17 \text { items; response = at least 50\% reduction), Mont- } \\
\text { gomery-Asberg Depression Rating Scale (MADRS), Clinical Global Impression Index (CGI) } \\
\text { Patient-rated: Symptom Check List (SCL-58) }\end{array}$} \\
\hline Notes & \multicolumn{2}{|c|}{$\begin{array}{l}\text { Trial with preplanned interim analysis with } 169 \text { patients (no significant difference) } \\
\text { Additional information provided by sponsor (Schwabe, Karlsruhe) }\end{array}$} \\
\hline \multicolumn{3}{|l|}{ Risk of bias } \\
\hline Bias & Authors' judgement & Support for judgement \\
\hline Allocation concealment? & Low risk & A - Adequate \\
\hline
\end{tabular}

Montgomery 2000

$\begin{array}{ll}\text { Methods } & \text { Concealment: unclear } \\ & \text { Blinding: double-blind } \\ & \text { Drop-outs/withdrawals: unclear }\end{array}$


Montgomery 2000 (Continued)

Jadad score: $1-2-0$

IV score: 1-0-0-1-1-0.5

\begin{tabular}{ll}
\hline Participants & Patients included/analyzed: $247 /$ ? \\
& Demographics: 183 female, mean age 43 years \\
& Diagnosis: mild to moderate depression (DSM-IV 296.2x/3x) \\
Setting: 18 GPs and psychiatric outpatient clinics in the UK \\
Baseline: HAMD about 22 in both groups (data extrapolated from figure in poster)
\end{tabular}

\begin{tabular}{ll}
\hline Interventions & Treatment: Hypericum extract LI $1603 \times 1$ coated tablet $(900 \mathrm{mg})$ for 12 weeks \\
Control: Placebo for 12 weeks
\end{tabular}

Control: Placebo for 12 weeks

\section{Outcomes Observation period: 3 to 7 days run-in, 12 weeks treatment}

Physician-rated: Hamilton depression Scale (HAMD, 17 items; response $=$ at least $50 \%$ reduction or score < 10), Montgomery-Asberg Depression Rating Scale (MADRS), Clinical Global Impression Index (CGI)

Patient-rated: None mentioned

Available as congress abstract and poster handout only. Additional information from sponsor
(Lichtwer, Berlin)

\section{Risk of bias}

\begin{tabular}{lll}
\hline Bias & Authors' judgement & Support for judgement \\
\hline Allocation concealment? & Unclear risk & B - Unclear \\
\hline
\end{tabular}

\section{Moreno 2005}

$\begin{array}{ll}\text { Methods } & \text { Concealment: unclear } \\ & \text { Blinding: double-blind (double-dummy technique) } \\ \text { Drop-outs/withdrawals: } 19 \text { of } 72 \text { (no details for single groups reported) } \\ \text { Jadad score: } 1-1-0 \\ \text { IV score: } 1-0-0-0.5-0.5-0\end{array}$

\begin{tabular}{ll}
\hline Participants & Number of patients included/analyzed: $72 / 66$ \\
& Demographics: $83 \%$ female, mean age 40 years \\
& Diagnosis: mild to moderate major depression (DSM-IV criteria) \\
Setting: Institute of Psychiatry, University Sao Paulo, Brasil & Baseline: extrapolated from figure HAMD score hypericum group 15, placebo 17, fluoxetine, 15
\end{tabular}

Interventions Treatment: Hypericum extract Iperisan $3 \times 1(900 \mathrm{mg})$ daily for 8 weeks
Control 1: Placebo

Control 2: Fluoxetine $20 \mathrm{mg} /$ day for 8 weeks ( 1 capsule fluoxetine and 2 capsules placebo per day)

$\begin{array}{ll}\text { Outcomes } & \text { Observation period: 1-week prerandomzationw ash-out, } 8 \text { weeks post randomization } \\ & \text { Physician-rated: Hamilton Depression Scale (HAMD, } 21 \text { items, response = at least 50\% redution, remis- } \\ & \text { sion < } 8 \text { on the } 17 \text { item scale), Montgomery-Asberg Depression rating Scale (MADRS), Clinical Global Im- } \\ \text { pression Index (CGI) } & \text { Patient-rated: none }\end{array}$

\section{Risk of bias}


Moreno 2005 (Continued)

\begin{tabular}{lll} 
Bias & Authors' judgement & Support for judgement \\
\hline Allocation concealment? & Unclear risk & B - Unclear \\
\hline
\end{tabular}

\section{Philipp 1999}

\begin{tabular}{|c|c|}
\hline Methods & $\begin{array}{l}\text { Concealment: numbered pharmacy } \\
\text { Blinding: Double-blind } \\
\text { Drop-outs/withdrawals: } 13 \text { of } 106 \text { (hypericum), } 11 \text { of } 110 \text { (imipramine), } 9 \text { of } 47 \text { (placebo) } \\
\text { Jadad score: } 2-2-1 \\
\text { IV score: } 1-1-1-0.5-0.5-0.5\end{array}$ \\
\hline Participants & $\begin{array}{l}\text { Patients included/analyzed: } 263 / 251 \\
\text { Demographics: } 197 \text { female, mean age } 47 \text { years } \\
\text { Diagnosis: moderate depression (ICD-10 F32.1/F32.2) } \\
\text { Setting: } 18 \text { GPs in Germany } \\
\text { Baseline: HAMD score } 22.7+/-4.2 \text { (hypericum), } 22.2+/-4.2 \text { (imipramine), } 22.7+/-4.0 \text { (placebo) }\end{array}$ \\
\hline Interventions & $\begin{array}{l}\text { Treatment: Hypericum extract STEI } 3003 \times 1 \text { capsule }(1050 \mathrm{mg}) \text { for } 8 \text { weeks } \\
\text { Control 1: Imipramine } 100 \mathrm{mg} \text { for } 8 \text { weeks } \\
\text { Control 2: Placebo for } 8 \text { weeks }\end{array}$ \\
\hline Outcomes & $\begin{array}{l}\text { Observation period: } 1 \text { week screening, } 8 \text { weeks treatment } \\
\text { Physician-rated: Hamilton Depression Scale (HAMD, } 17 \text { items; response = at least 50\% reduction), } \\
\text { Hamilton Anxiety Scale (HAMA), Clinical Global Impression Scale (CGI) } \\
\text { Patient-rated: Zung Depression Scale, Quality of life (SF-36) }\end{array}$ \\
\hline Notes & $\begin{array}{l}\text { Additional information from sponsor (Steiner, Berlin). Primary outcome comparison with placebo after } \\
6 \text { weeks, with imipramine after } 8 \text { weeks }\end{array}$ \\
\hline \multicolumn{2}{|l|}{ Risk of bias } \\
\hline Bias & Authors' judgement Support for judgement \\
\hline Allocation concealment? & A - Adequate \\
\hline
\end{tabular}

Schrader 1998

\begin{tabular}{|c|c|}
\hline Methods & $\begin{array}{l}\text { Concealment: numbered pharmacy } \\
\text { Blinding: double-blind } \\
\text { Drop-outs/withdrawals: } 1 \text { of } 81 \text { (hypericum), } 2 \text { of } 81 \text { (placebo) } \\
\text { Jadad score: } 2-2-1 \\
\text { IV score: } 1-0-0-1-1-1\end{array}$ \\
\hline Participants & $\begin{array}{l}\text { Patients included/analyzed: } 162 / 159 \\
\text { Demographics: } 108 \text { female, mean age } 47 \text { (hypericum) vs. } 39 \text { (placebo) } \\
\text { Diagnosis: mild to moderate depression (F32.0/32.1) } \\
\text { Setting: } 16 \text { private practices in Germany } \\
\text { Baseline: HAMD values } 20.1+/-2.8 \text { (hypericum) vs. } 18.7+/-3.5\end{array}$ \\
\hline Interventions & $\begin{array}{l}\text { Treatment: } 2 \times 1 \text { coated tablet ( } 500 \text { mg extract) Hypericum extract ZE } 117 \text { daily for } 6 \text { weeks } \\
\text { Control: Placebo }\end{array}$ \\
\hline Outcomes & Observation period: 6 weeks \\
\hline
\end{tabular}

St John's wort for major depression (Review) 
Schrader 1998 (Continued)

Physician-rated: Hamilton Depression Scale (HAMD, 21 items; response $=$ at least 50\% reduction or score < 10), Clinical Global Impression Index (CGI)

Patient-rated: visual analogue scale

Notes

Additional information provided by author and sponsor (Zeller AG, Romanshorn, Switzerland). Baseline HAMD score lower in placebo group. Low response rate in placebo group.

In meta-analyses HAMD values were calculated for the 17 -item version (data provided by author)

\section{Risk of bias}

\begin{tabular}{lll}
\hline Bias & Authors' judgement & Support for judgement \\
\hline Allocation concealment? & Low risk & A - Adequate \\
\hline
\end{tabular}

Schrader 2000

$\begin{array}{ll}\text { Methods } & \text { Concealment: numbered pharmacy } \\ & \text { Blinding: double-blind (double-dummy) } \\ \text { Drop-outs/withdrawals: } 1 \text { of } 126 \text { (hypericum), } 1 \text { of } 113 \text { (fluoxetine) } \\ \text { Jadad score: } 1-2-1 \\ \text { IV score: } 1-0-1-0.5-0.5-1\end{array}$

\begin{tabular}{ll}
\hline Participants & Patients included/analyzed: $230 / 228$ \\
& Demographics: 157 female, mean age 46 years \\
& Diagnosis: mild to moderate depression (ICD-10 F32.0/32.1) \\
Setting: 7 practices (internal medicine) in Germany & Baseline: HAMD values $19.6+/-3.1$ (hypericum), $19.5+/-2.4$ (fluoxetine)
\end{tabular}

\begin{tabular}{ll} 
Interventions & Treatment: Hypericum extract Ze $1172 \times 1$ coated tablet $(500 \mathrm{mg})$ for 6 weeks \\
& Control: Fluoxetine $1 \times 1$ capsule $(20 \mathrm{mg})$ for 6 weeks \\
\hline Outcomes & Observation period: 6 weeks \\
& Physician-rated: Hamilton Depression Scale (HAMD, 21 items; response = at least $50 \%$ reduction or \\
& score $<10)$, Clinical Global Impression $(C G I)$ \\
& Physician-rated: visual analogue scale
\end{tabular}

Notes Additional information (particulary responder rates and 17-item HAMD scores) provided by author and sponsor (Zeller AG, Romanshorn, Switzerland)

\section{Risk of bias}

\begin{tabular}{lll}
\hline Bias & Authors' judgement & Support for judgement \\
\hline Allocation concealment? & Low risk & A - Adequate \\
\hline
\end{tabular}

\section{Shelton 2001}

\begin{tabular}{ll}
\hline Methods & Concealment: numbered pharmacy \\
& Blinding: double-blind \\
& Drop-outs/withdrawals:15 of 98 (hypericum), 13 of 102 (placebo) \\
& Jadad score: $2-2-1$ \\
& IV score: $1-1-1-1-1-1$ \\
\hline Participants & Patients included/analyzed: $200 / 195$
\end{tabular}


Shelton 2001 (Continued)

Demographics: $64 \%$ female, mean age 42 years

Diagnosis: major depression (DSM-IV)

Setting: 11 academic medical centers in the USA

Baseline: mean HAMD values above 22 in both groups

Treatment: Hypericum extract LI $1603 \times 1$ to $4 \times 1$ tablet (900 to $1200 \mathrm{mg}$ ) for 8 weeks
Control: placebo for 8 weeks

$\begin{array}{ll}\text { Outcomes } & \text { Observation period: } 1 \text { week run-in, } 8 \text { weeks treatment } \\ & \text { Phsician-rated: Hamilton Depression Scale (HAMD, } 17 \text { items, at least 50\% reduction), Clinical Global Im- } \\ \text { pression Index (CGI), Hamilton Anxiety Scale (HAMA) } \\ \text { Patient-rated: Beck Depression Inventory (BDI) }\end{array}$

Notes Average duration of current depressive episode more than 2 years. Additional information provided from authors

\begin{tabular}{lll}
\hline Risk of bias & \\
\hline Bias & Authors' judgement & Support for judgement \\
\hline Allocation concealment? & Low risk & A-Adequate \\
\hline
\end{tabular}

\section{Szegedi 2005}

\begin{tabular}{|c|c|}
\hline Methods & $\begin{array}{l}\text { Allocation concealment: numbered pharmacy } \\
\text { Blinding: double-blind (double dummy technique) } \\
\text { Drop-out/wothdrawals: } 17 \text { of } 125 \text { in hypericum group, } 29 \text { of } 126 \text { in the paroxetine group } \\
\text { Jadad score: } 2-2-1 \\
\text { IV score: } 1-1-1-0.5-0.5-0.5\end{array}$ \\
\hline Participants & $\begin{array}{l}\text { Number of patients included/analyzed: } 251 / 244 \\
\text { Demographics: } 69 \% \text { female, mean age } 47 \text { years } \\
\text { Diagnosis: moderate or severe unupolar major depression (DSM IV 296.22/23, 296.32/33) } \\
\text { Setting: } 21 \text { Psychiatric primary care centers in Germany } \\
\text { Baseline: HAMD score } 25.5 .+/-2.7 \text { (hypericum), } 25.5+/-2.9 \text { (paroxetine) }\end{array}$ \\
\hline Interventions & $\begin{array}{l}\text { Treatment: } 3 \times 1 \text { tablet ( } 900 \mathrm{mg} \text { daily) hypericum extract WS } 5570 \text { daily for } 6 \text { weeks (in patients whose } \\
\text { depression score was not improved by at least } 20 \% 3 \times 600 \mathrm{mg} \text { were used after } 2 \text { weeks) } \\
\text { Control: } 1 \times 1 \text { tablet }(20 \mathrm{mg} \text { ) paroxetine daily for } 6 \text { weeks (in patients whose depression score was not } \\
\text { improved by at least } 20 \% 40 \mathrm{mg} \text { were used after } 2 \text { weeks) packed in capsules } \\
\text { For each drug an indentically matched placebo was available }\end{array}$ \\
\hline Outcomes & $\begin{array}{l}\text { Observation period: } 6 \text { weeks (+ } 16 \text { weeks continuation phase) } \\
\text { Physician-reated: Hamilton Depression Scale (HAMD, } 17 \text { items, at least } 50 \% \text { reduction), Clinical Global } \\
\text { Impression (CGI), Montgomery-Asberg Depression Rating Scale (MADRS) } \\
\text { Patient-rated: Beck Depression Inventory (BDI) }\end{array}$ \\
\hline Notes & Additional information provided by sponsor \\
\hline \multicolumn{2}{|l|}{ Risk of bias } \\
\hline Bias & Support for judgement \\
\hline Allocation concealment? & A - Adequate \\
\hline
\end{tabular}


Uebelhack 2004

\begin{tabular}{|c|c|}
\hline Methods & $\begin{array}{l}\text { Concelment: consecutively numbered pharmacy } \\
\text { Blinding: double-blind } \\
\text { Drop-out/withdrawals: none } \\
\text { Jadad score: } 2-2-1 \\
\text { IV score: } 1-0-1-1-1-1\end{array}$ \\
\hline Participants & $\begin{array}{l}\text { Number of patients included/analyzed: } 140 / 140 \\
\text { Demographics: } 67 \% \text { female, mean age } 45 \text { years } \\
\text { Diagnosis: moderate depressive disorder (ICD-10 F32.1 or F33.1) } \\
\text { Setting: clinical trial center in Germany } \\
\text { Baseline: } 22-.8+/-1.1 \text { in hypericum group, } 22.8+/-1.2 \text { in placebo group }\end{array}$ \\
\hline Interventions & $\begin{array}{l}\text { Treatment: } 1 \times 1 \text { tablet }(900 \mathrm{mg} \text { ) STW3-VI daily for } 6 \text { weeks } \\
\text { Control: Placebo }\end{array}$ \\
\hline Outcomes & $\begin{array}{l}\text { Observation period: } 6 \text { weeks } \\
\text { Physician-rated: Hamitlon Depression Scale (HAMD, } 17 \text { items; response }=\text { HAMD score }<10 \text { or at least } \\
50 \% \text { reduction), Clinical Global Impression Index (CGI) } \\
\text { Patient-rated: Adjective Mood Scale (BfS) }\end{array}$ \\
\hline Notes & $\begin{array}{l}\text { Trial performed in a single clinical trial unit with short recruitment period and low placebo response. } \\
\text { Additional information from sponsor }\end{array}$ \\
\hline \multicolumn{2}{|l|}{ Risk of bias } \\
\hline Bias & Authors' judgement Support for judgement \\
\hline Allocation concealment? & A - Adequate \\
\hline
\end{tabular}

van Gurp 2002

$\begin{array}{ll}\text { Methods } & \text { Concealment: independent pharmacist } \\ & \text { Blinding: double-blind } \\ & \text { Drop-outs/withdrawals: } 16 \text { of } 45 \text { (hypericum), } 17 \text { of } 45 \text { (sertraline) } \\ & \text { Jadad score: } 2-2-1 \\ & \text { IV score: } 1-1-1-0.5-0.5-0\end{array}$

\begin{tabular}{ll}
\hline Participants & Patients included/analyzed: $90 / 87$ \\
& Demographics: $61 \%$ female, mean age 40 years) \\
& Diagnosis: major depression (DSM IV) \\
Setting: 12 community based offices for family medicine in Canada \\
Baseline: mean HAMD values $18.8+/-3.6$ (hypericum group), $19.7+/-3.5$ (sertraline group)
\end{tabular}

Interventions Treatment: $3 \times 1$ to $3 \times 2$ (in case of insufficient response at 4 weeks) capsules (900-1800 mg) Hypericum extract daily for 12 weeks

Control: $3 \times 1$ to $3 \times 2$ (in case of insufficient response at 4 weeks) capsules Sertraline (50 to $100 \mathrm{mg}$ ) daily for 12 weeks

In 9 patients of each group the dosage was doubled during the trial

$\begin{array}{ll}\text { Outcomes } & \text { Observation period: } 6 \text { weeks } \\ & \text { Physician-rated: Hamilton Depression Scale (HAMD, } 17 \text { items; response = at least } 50 \% \text { reduction or } \\ & \text { score }<10) \\ & \text { Patient-rated: Beck Depression Inventory (BDI) }\end{array}$


van Gurp 2002 (Continued)

Risk of bias

\begin{tabular}{lll}
\hline Bias & Authors' judgement & Support for judgement \\
\hline Allocation concealment? & Low risk & A - Adequate \\
\hline
\end{tabular}

Volz 2000

\begin{tabular}{|c|c|}
\hline Methods & $\begin{array}{l}\text { Concealment: numbered pharmacy } \\
\text { Blinding: double-blind } \\
\text { Drop-outs/withdrawals:2/71 (hypericum), 5/71 (placebo) } \\
\text { Jadad score: } 1-2-0 \\
\text { IV score: } 1-1-1-1-1-0.5\end{array}$ \\
\hline Participants & $\begin{array}{l}\text { Patients included/analyzed: } 142 / 140 \\
\text { Demographics: } 81 \% \text { female, mean age } 47 \text { years } \\
\text { Diagnosis: mild or moderate episode of a major depression (DSM-IV) } \\
\text { Setting: } 17 \text { practices for psychiatry, neurology, internal medicine and GP in Germany } \\
\text { Baseline: HAMD } 21.0+/-2.0 \text { (hypericum group), } 20.7+/-1.9 \text { (placebo group) }\end{array}$ \\
\hline Interventions & $\begin{array}{l}\text { Treatment: } 2 \times 1 \text { capsule ( } 500 \mathrm{mg} \text { ) Hypericum extract D-0496 daily for } 6 \text { weeks } \\
\text { Control: Placebo }\end{array}$ \\
\hline Outcomes & $\begin{array}{l}\text { Observation period: } 1 \text { week placebo run in, } 6 \text { weeks treatment } \\
\text { Phyiscian-rated: Hamilton Depression Scale (HAMD, } 21 \text { items; response = at least } 50 \% \text { reduction), Clini- } \\
\text { cal Global Impression Index (CGI) } \\
\text { Patient-rated: von Zerssen Depression Scale (D-S) }\end{array}$ \\
\hline Notes & Manufacturer/sponsor no longer existing. Author could provide only minimal additional information \\
\hline \multicolumn{2}{|l|}{ Risk of bias } \\
\hline Bias & Authors' judgement Support for judgement \\
\hline Allocation concealment? & A - Adequate \\
\hline
\end{tabular}

Vorbach 1997

$\begin{array}{ll}\text { Methods } & \text { Concealment: numbered pharmacy } \\ & \text { Blinding: double-blind } \\ & \text { Drop-outs/withdrawals: } 9 \text { of } 107 \text { in hypericum group, } 14 \text { of } 102 \text { in imipraimine group } \\ & \text { Jadad score: } 2-2-1 \text {, IV score: } 1-1-0.5-0.5-0.5-0.5\end{array}$

\begin{tabular}{ll}
\hline Participants & Number of patients included/analyzed: 209/209 (186 per protocol) \\
& Demographics: 154 female, mean age 49 years \\
& Diagnosis: severe episode of a major depression \\
& Setting: 20 psychiatric practices \\
& Baseline: HAMD score $25.3+/-4.7$ (hypericum group), $26.1+/-4.8$ (imipramine group) \\
\hline Interventions & Treatment: $3 \times 2$ coated tablets ( $1800 \mathrm{mg}$ extract) Hypericum extract LI 160 daily for 6 weeks \\
& Control: $3 \times 2$ coated tablets imipramine (150 mg) daily for 6 weeks
\end{tabular}


Vorbach 1997 (Continued)

Physician-rated: Hamilton Depression Scale (HAMD, 17 items; response $=$ at least $50 \%$ reduction), Clini-

cal Global Impression Index (CGI)

Patient-rated: Depression-Scale (D-S von Zerssen)

Notes Additional information provided from sponsor

\section{Risk of bias}

\begin{tabular}{lll}
\hline Bias & Authors' judgement & Support for judgement \\
\hline Allocation concealment? & Low risk & A - Adequate \\
\hline
\end{tabular}

\section{Wheatley 1997}

\begin{tabular}{|c|c|}
\hline Methods & $\begin{array}{l}\text { Concealment: numbered pharmacy } \\
\text { Blinding: double-blind } \\
\text { Drop-outs/withdrawals: } 20 \text { of } 87 \text { in hypericum group, } 24 \text { of } 78 \text { amitriptyline group } \\
\text { Jadad score: } 2-2-0 \\
\text { IV score: } 1-1-0.5-0.5-0.5-0.5\end{array}$ \\
\hline Participants & $\begin{array}{l}\text { Number of patients included/analyzed: } 165 / 156 \\
\text { Demographics: } 126 \text { female, mean age } 40 \text { years } \\
\text { Diagnosis: major depression (DSM-IV) } \\
\text { Setting: } 18 \text { general practices and one hospital outpatient clinic in the UK } \\
\text { Baseline: HAMD score } 20.6+/-2.1 \text { (hypericum group), } 20.8+/-2.3 \text { (amitriptyline group) }\end{array}$ \\
\hline Interventions & $\begin{array}{l}\text { Treatment: } 3 \times 1 \text { coated tablet ( } 900 \mathrm{mg} \text { extract) Hypericum extract LI } 160 \text { daily for } 6 \text { weeks } \\
\text { Control: } 3 \times 1 \text { coated tablet amitriptyline }(75 \mathrm{mg} \text { ) daily for } 6 \text { weeks }\end{array}$ \\
\hline Outcomes & $\begin{array}{l}\text { Observation period: } 6 \text { weeks } \\
\text { Physician-rated: Hamilton Depression Scale (HAMD, } 17 \text { items; response = at least } 50 \% \text { reduction or } \\
\text { score < 10), Montgomery-Asberg Reating Scale for Depression (MADRS), Clinical Global Impression In- } \\
\operatorname{dex}(\mathrm{CGI})\end{array}$ \\
\hline Notes & Some additional information provided from sponsor. HAMD mean values extrapolated from figure \\
\hline \multicolumn{2}{|l|}{ Risk of bias } \\
\hline Bias & Authors' judgement Support for judgement \\
\hline Allocation concealment? & A - Adequate \\
\hline
\end{tabular}

Witte 1995

\begin{tabular}{ll}
\hline Methods & Concealment: numbered pharmacy \\
& Blidning: double-blind \\
& Drop-outs/withdrawals: 1 of 48 in hypericum group, 1 of 49 in placebo group \\
& Jadad score: $1-2-1$ \\
& IV score: $1-0-0.5-1-1-0.5$ \\
\hline Participants & Number of patients included/analyzed: $97 / 95$ \\
& Demographics: 64 female, mean age 43 years \\
& Diagnosis: depression (ICD-10 F32.1) \\
& Setting: 5 general practitioners in Germany
\end{tabular}

St John's wort for major depression (Review) 
Witte 1995 (Continued)

Baseline: HAMD score 24.6 +/5.4 (hypericum group), $22.7+/-4.4$ (placebo group)

Interventions Treatment: $2 x 1$ capsules (200 to $240 \mathrm{mg}$ ) Hypericum extract (Psychotonin forte) daily for 6 weeks Control: placebo

Observation period: 6 weeks
Physician-rated: Hamilton Depression Scale (HAMD, 21 items; response = at least 50\% reduction or
score < 10), Clinical Global Impression Index (CGI)
Patient-rated: Depression Scale (D-S von Zerssen), State Trait Anxiety Inventory (STAI)

Notes Additional information provided by author

\section{Risk of bias}

\begin{tabular}{lll}
\hline Bias & Authors' judgement & Support for judgement \\
\hline Allocation concealment? & Low risk & A - Adequate \\
\hline
\end{tabular}

Woelk 2000

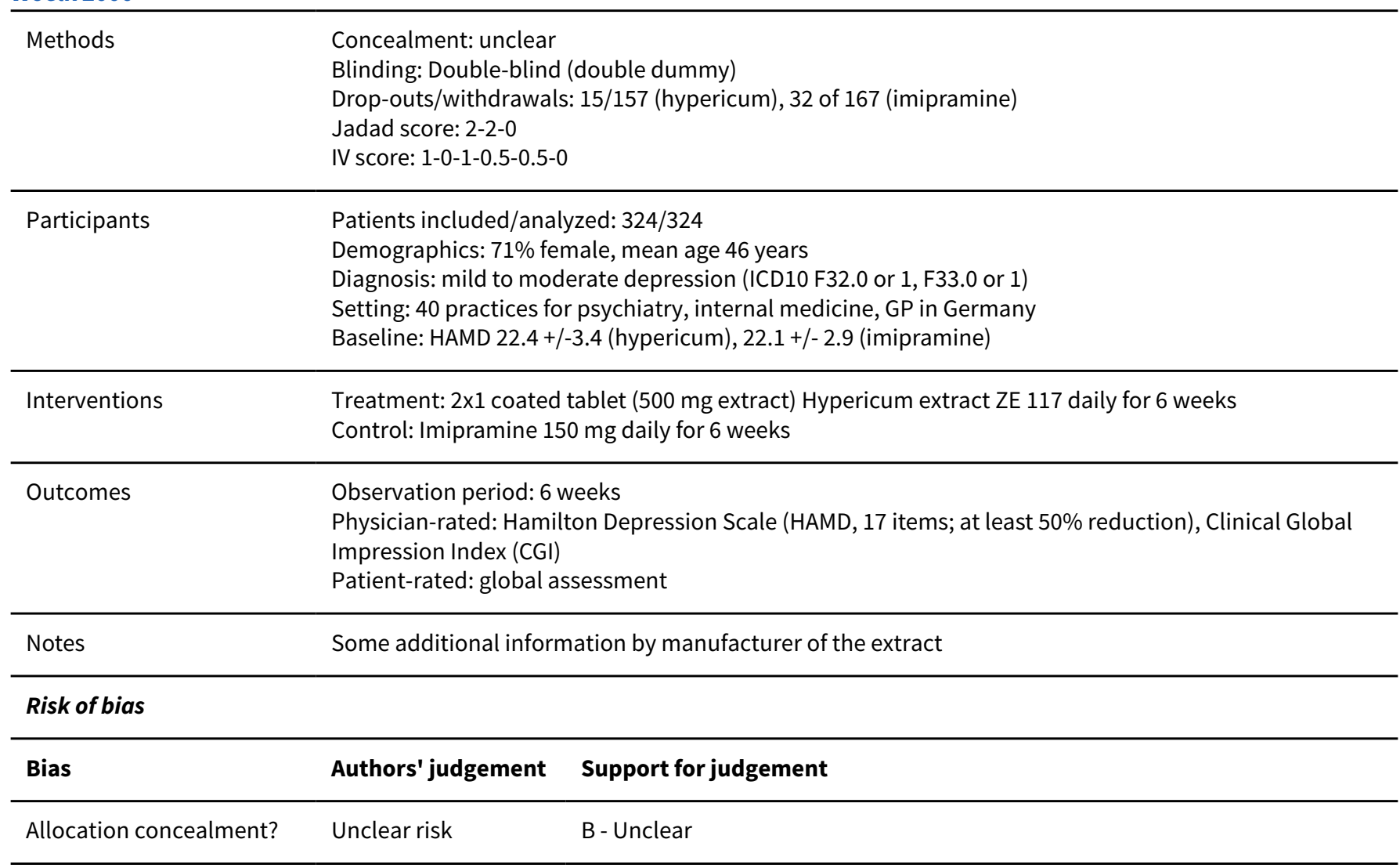

\section{Characteristics of excluded studies [ordered by study ID]}

\begin{tabular}{ll}
\hline Study & Reason for exclusion \\
\hline Agrawal 1994 & Not major depression (Study in patients with fatigue and minor depression) \\
\hline \hline
\end{tabular}

St John's wort for major depression (Review)

Copyright $\odot 2009$ The Cochrane Collaboration. Published by John Wiley \& Sons, Ltd. 


\begin{tabular}{ll}
\hline Study & Reason for exclusion \\
\hline Albertini 1986 & Not depression (RCT of hypericum in homeopathic preparation for dental neuralgia) \\
\hline Bendre 1980 & Not depression (CCT of homeopathic preparations of hypericum and arnica in dental practice) \\
\hline Bergmann 1993 & Inadequate dosage of amitriptyline (30 mg daily) - RCT included in previous versions of this review \\
\hline Bernhadt 1993 & RCT comparing two doses of hypericum for depression \\
\hline Brockmöller 1997 & RCT on pharmacokinetics and photosensitivity in healthy volunteers \\
\hline Czekalla 1997 & Report of results on ECG analyses undertaken in the Vorbach 1997 study \\
\hline Dittmer 1992 & $\begin{array}{l}\text { Only a minority of patients suffered from depression (RCT of Hypericum for "psychovegetative } \\
\text { complaints") }\end{array}$ \\
\hline Ditzler 1992 & $\begin{array}{l}\text { Placebo-controlled randomized controlled trial in depressed patients using a fixed combination of } \\
\text { several herbs including hypericum }\end{array}$ \\
\hline
\end{tabular}

Gu 2001

RCT comparing $900 \mathrm{mg}$ of a hypericum extract with fluoxetine in patients with depression according to the Chinese classification CCMD-2. As it is not clear whether all included patients meet criteria for major depression the study was excluded. Response rates were similar in both groups

\begin{tabular}{|c|c|}
\hline Halama 1991 & Not major depression (placebo-controlled trial included in previous versions of the review) \\
\hline Harrer 1991 & Not major depression (placebo-controlled trial included in previous versions of the review) \\
\hline Herberg 1992 & $\begin{array}{l}\text { RCT comparing hypericum and a combination of Hypericum and Valerian on concentration, reac- } \\
\text { tion etc. in healthy volunteers }\end{array}$ \\
\hline Hoffmann 1979 & Not major depression (placebo-controlled trial included in previous versions of the review) \\
\hline Hottenrott 1997 & $\begin{array}{l}\text { Not depression (RCT of a combination of hypericum and vitamine } E \text { to enhance performance of } \\
\text { athlets) }\end{array}$ \\
\hline Häring 1996 & $\begin{array}{l}\text { Placebo-controlled RCT of hypericum to prevent reactive depression in } 28 \text { patients with solid tu- } \\
\text { mors undergoing chemotherapy }\end{array}$ \\
\hline Hübner 1993 & Not major depression (placebo-controlled trial included in previous versions of the review) \\
\hline Johnson 1992 & RCT on neurophysiological effects of hypericum in healthy volunteers \\
\hline Johnson 1993 & RCT comparing neurophysiological effects of hypericum and maprotiline in healthy volunteers \\
\hline Kniebel 1988 & RCT comparing a combination of hypericum and valerian vs. amitriptyline in depressive patients \\
\hline Kugler 1990a & $\begin{array}{l}\text { RCT comparing hypericum and bromazepam in depressed patients (included in earlier versions of } \\
\text { this review; inclusion has now been limited to commonly recommended standard antidepressants) }\end{array}$ \\
\hline Kugler 1990b & $\begin{array}{l}\mathrm{RCT} \text { on pharmacodynamics in depressed patients (reason for exclusion: no symptomatic outcomes } \\
\text { related to depressive symptoms) }\end{array}$ \\
\hline König 1993 & Not major depression (placebo-controlled trial included in previous versions of the review) \\
\hline Lehrl 1993 & $\begin{array}{l}\text { Diagnosis not decscribed as major depression in publication. An information collected from the } \\
\text { sponsor for a previous version of the review that patients met criteria for major depression could } \\
\text { not be verified (placebo-controlled trial included in previous versions of the review) }\end{array}$ \\
\hline
\end{tabular}




\begin{tabular}{|c|c|}
\hline Study & Reason for exclusion \\
\hline Lenoir 1999 & $\mathrm{RCT}$ comparing three dosages of a hypericum extract in depressive patients \\
\hline Li 2005 & $\begin{array}{l}\text { Not major depression (placebo-controlled RCT in depressive patients undergoing coronary artery } \\
\text { bypass grafting) }\end{array}$ \\
\hline Maisenbacher 1995 & Not all patients suffered from depression (RCT of hypericum for anxiety) \\
\hline Martinez 1993 & $\begin{array}{l}\text { RCT comparing light therapy and a combination of light therapy and hypericum in patients with } \\
\text { seasonal affective disorder }\end{array}$ \\
\hline Mo 2004 & $\begin{array}{l}\text { Not major depression (RCT comparing an hypericum extract and fluoxetine in post-stroke depres- } \\
\text { sion) }\end{array}$ \\
\hline Osterheider 1992 & Not major depression (placebo-controlled trial included in previous versions of the review) \\
\hline Panijel 1985 & Not depression (RCT of a combination of hypericum and valerian for anxiety) \\
\hline Quandt 1993 & Not major depression (placebo-controlled trial included in previous versions of the review) \\
\hline Reh 1992 & Not major depression (placebo-controlled trial included in previous versions of the review) \\
\hline Schlich 1987 & Not major depression (placebo-controlled trial included in previous versions of the review) \\
\hline Schmidt 1989 & Not major depression (placebo-controlled trial included in previous versions of the review) \\
\hline Schmidt 1993 & Not major depression (placebo-controlled trial included in previous versions of the review) \\
\hline Schmidt 1993b & RCT investigating possible interactions of hypericum and alcohol in healthy volunteers \\
\hline Schulz 1993 & RCT investigating the effects of hypericum on the sleep-EEG in elderly volunteers \\
\hline Sindrup 2000 & $\mathrm{RCT}$ in patients with polyneuropathy (depression not mentioned) \\
\hline Sommer 1994 & Not major depression (placebo-controlled trial included in previous versions of the review) \\
\hline Spielberger 1985 & RCT comparing two hypericum preparations for depression \\
\hline Staffeldt 1993 & $\mathrm{RCT}$ on pharmacokinetics in healthy volunteers \\
\hline Steger 1985 & RCT of a comination of of hypericum and valerian vs. desipramine for depression \\
\hline Volz 2002 & RCT hypreicum vs. placebo in patients with somatoform disorders \\
\hline Vorbach 1994 & $\begin{array}{l}\text { Not all patients met criteria for major depression (comparison with maprotiline; included in previ- } \\
\text { ous versions of the review) }\end{array}$ \\
\hline Warnecke 1986 & $\begin{array}{l}\text { Open controlled trial of hypericum vs. diazepam in women with climacteric depression; method } \\
\text { of allocation unclear (included in earlier version of this review; now inclusion limited to explicitely } \\
\text { randomized, double-blind trials) }\end{array}$ \\
\hline Werth 1989 & $\begin{array}{l}\text { RCT of hypericum vs. amitriptyline for about two weeks in patients undergoing amputation to pre- } \\
\text { vent reactive depression (included in earlier version of this review) }\end{array}$ \\
\hline Wienert 1991 & RCT on photosensitivtity after application of a combination of hypericum and valerian \\
\hline
\end{tabular}




\begin{tabular}{ll}
\hline Study & Reason for exclusion \\
\hline Winkel 2000 & Not major depression (placebo-controlled trial included in previous versions of the review) \\
\hline Zeller 2000 & $\begin{array}{l}\text { (Nonrandomized?) comparison of different administration schedules of a hypericum extract in pa- } \\
\text { tients with mild to moderate depression (not restricted to major depression) }\end{array}$ \\
\hline
\end{tabular}

DATA AND ANALYSES

Comparison 1. Hypericum mono-preparations vs. placebo A. Dichotomous measures

\begin{tabular}{|c|c|c|c|c|}
\hline Outcome or subgroup title & $\begin{array}{l}\text { No. of } \\
\text { studies }\end{array}$ & $\begin{array}{l}\text { No. of } \\
\text { partici- } \\
\text { pants }\end{array}$ & Statistical method & Effect size \\
\hline $\begin{array}{l}1 \text { Responder - grouped by pre- } \\
\text { cision - primary analysis }\end{array}$ & 18 & 3064 & Risk Ratio (M-H, Random, 95\% Cl) & $1.48[1.23,1.77]$ \\
\hline 1.1 Less precise trials & 9 & 1020 & Risk Ratio (M-H, Random, 95\% Cl) & $1.87[1.22,2.87]$ \\
\hline 1.2 More precise trials & 9 & 2044 & Risk Ratio (M-H, Random, 95\% Cl) & $1.28[1.10,1.49]$ \\
\hline $\begin{array}{l}2 \text { Responder - according to } \\
\text { HAMD }\end{array}$ & 16 & 2706 & Risk Ratio (M-H, Random, 95\% Cl) & $1.51[1.22,1.87]$ \\
\hline 2.1 Less precise trials & 8 & 948 & Risk Ratio (M-H, Random, 95\% Cl) & $1.94[1.19,3.18]$ \\
\hline 2.2 More precise trials & 8 & 1758 & Risk Ratio (M-H, Random, 95\% Cl) & $1.28[1.06,1.53]$ \\
\hline $\begin{array}{l}3 \text { Responder - according to CGI } \\
\text { (Clinical Global Impression In- } \\
\text { dex at least "much improved") }\end{array}$ & 13 & 2306 & Risk Ratio (M-H, Random, 95\% Cl) & $1.47[1.24,1.74]$ \\
\hline 3.1 Less precise trials & 7 & 869 & Risk Ratio (M-H, Random, 95\% Cl) & $1.74[1.30,2.33]$ \\
\hline 3.2 More precise trials & 6 & 1437 & Risk Ratio (M-H, Random, 95\% Cl) & $1.26[1.06,1.50]$ \\
\hline $\begin{array}{l}4 \text { Responder - grouped by ex- } \\
\text { tract }\end{array}$ & 18 & & Risk Ratio (M-H, Random, 95\% Cl) & Subtotals only \\
\hline 4.1 extract LI 160 & 6 & 981 & Risk Ratio (M-H, Random, 95\% Cl) & $1.31[0.92,1.86]$ \\
\hline 4.2 extract WS 5570 & 2 & 699 & Risk Ratio (M-H, Random, 95\% Cl) & $1.57[0.96,2.56]$ \\
\hline 4.3 extract WS 5572 & 2 & 170 & Risk Ratio (M-H, Random, 95\% Cl) & $1.47[1.05,2.06]$ \\
\hline 4.4 extract STW3-VI & 2 & 401 & Risk Ratio (M-H, Random, 95\% Cl) & $3.59[0.41,31.56]$ \\
\hline 4.5 other extracts & 6 & 813 & Risk Ratio (M-H, Random, 95\% Cl) & $1.45[1.08,1.93]$ \\
\hline $\begin{array}{l}5 \text { Responder among studies } \\
\text { from German-speaking coun- } \\
\text { tries and other studies }\end{array}$ & 18 & 3064 & Risk Ratio (M-H, Random, 95\% Cl) & $1.48[1.23,1.77]$ \\
\hline
\end{tabular}




\begin{tabular}{lllll}
\hline Outcome or subgroup title & $\begin{array}{l}\text { No. of } \\
\text { studies }\end{array}$ & $\begin{array}{l}\text { No. of } \\
\text { partici- } \\
\text { pants }\end{array}$ & Statistical method & Effect size \\
\hline $\begin{array}{l}5.1 \text { Studies from Ger- } \\
\text { man-speaking countries }\end{array}$ & 11 & 1770 & Risk Ratio $(\mathrm{M}-\mathrm{H}$, Random, 95\% Cl) & $1.78[1.42,2.25]$ \\
\hline $\begin{array}{l}5.2 \text { Studies from other coun- } \\
\text { tries }\end{array}$ & 7 & 1294 & Risk Ratio $(\mathrm{M}-\mathrm{H}$, Random, 95\% Cl) & $1.07[0.88,1.31]$ \\
\hline $\begin{array}{l}6 \text { Remission (HAMD score }<8 \\
\text { or }<7 \text { ) }\end{array}$ & 6 & 1236 & Odds Ratio $(\mathrm{M}-\mathrm{H}$, Random, $95 \% \mathrm{Cl})$ & $2.77[1.80,4.26]$ \\
\hline
\end{tabular}

\section{Analysis 1.1. Comparison 1 Hypericum mono-preparations vs. placebo A. Dichotomous measures, Outcome 1 Responder - grouped by precision - primary analysis.}

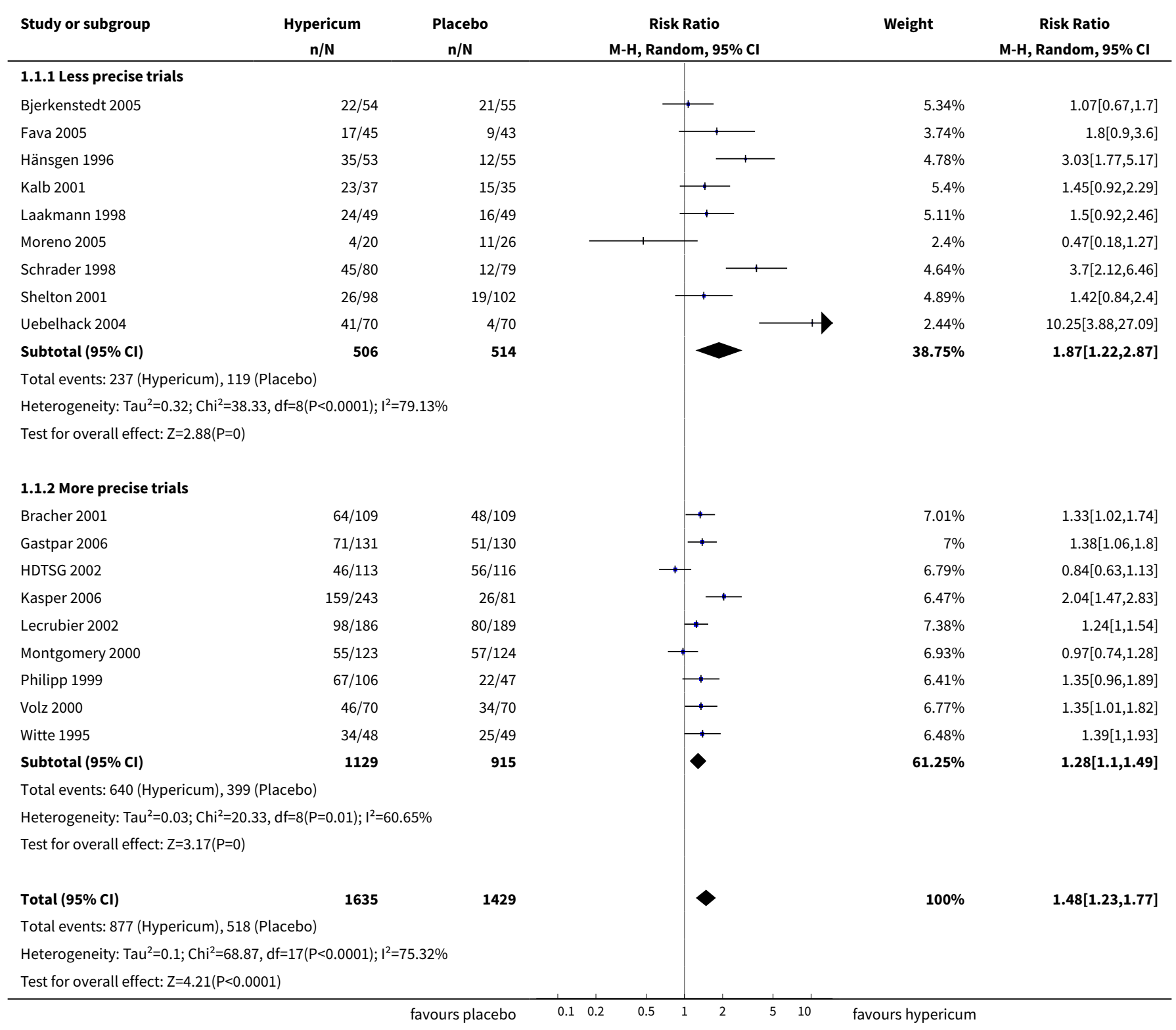




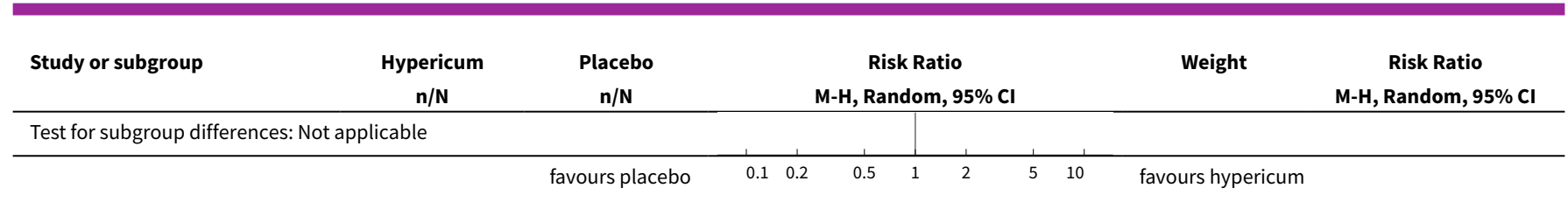

Analysis 1.2. Comparison 1 Hypericum mono-preparations vs. placebo A. Dichotomous measures, Outcome 2 Responder - according to HAMD.

\begin{tabular}{|c|c|c|c|c|c|}
\hline Study or subgroup & $\begin{array}{c}\text { Hypericum } \\
\mathrm{n} / \mathrm{N} \\
\end{array}$ & $\begin{array}{c}\text { Placebo } \\
\mathbf{n} / \mathbf{N}\end{array}$ & $\begin{array}{c}\text { Risk Ratio } \\
\text { M-H, Random, 95\% Cl }\end{array}$ & Weight & $\begin{array}{c}\text { Risk Ratio } \\
\text { M-H, Random, } 95 \% \text { CI }\end{array}$ \\
\hline \multicolumn{6}{|c|}{ 1.2.1 Less precise trials } \\
\hline Bjerkenstedt 2005 & $22 / 54$ & $21 / 55$ & - & $6.27 \%$ & $1.07[0.67,1.7]$ \\
\hline Fava 2005 & $17 / 45$ & $9 / 43$ & & $4.62 \%$ & $1.8[0.9,3.6]$ \\
\hline Hänsgen 1996 & $35 / 53$ & $12 / 55$ & $\longrightarrow$ & $5.72 \%$ & $3.03[1.77,5.17]$ \\
\hline Laakmann 1998 & $24 / 49$ & $16 / 49$ & & $6.05 \%$ & $1.5[0.92,2.46]$ \\
\hline Schrader 1998 & $45 / 80$ & $12 / 79$ & $\longrightarrow$ & $5.57 \%$ & $3.7[2.12,6.46]$ \\
\hline Shelton 2001 & $26 / 98$ & $19 / 102$ & & $5.82 \%$ & $1.42[0.84,2.4]$ \\
\hline Uebelhack 2004 & $41 / 70$ & $4 / 70$ & & $3.15 \%$ & $10.25[3.88,27.09]$ \\
\hline Subtotal $(95 \% \mathrm{CI})$ & 469 & 479 & & $40.28 \%$ & $1.94[1.19,3.18]$ \\
\hline \multicolumn{6}{|c|}{ Total events: 214 (Hypericum), 104 (Placebo) } \\
\hline \multicolumn{6}{|c|}{ Heterogeneity: Tau $^{2}=0.4 ; \mathrm{Chi}^{2}=37.14, \mathrm{df}=7(\mathrm{P}<0.0001) ; \mathrm{I}^{2}=81.15 \%$} \\
\hline \multicolumn{6}{|c|}{ Test for overall effect: $Z=2.64(P=0.01)$} \\
\hline \multicolumn{6}{|c|}{ 1.2.2 More precise trials } \\
\hline Gastpar 2006 & $71 / 131$ & $51 / 130$ & $\rightarrow$ & $7.83 \%$ & $1.38[1.06,1.8]$ \\
\hline HDTSG 2002 & $46 / 113$ & $56 / 116$ & $\rightarrow$ & $7.64 \%$ & $0.84[0.63,1.13]$ \\
\hline Kalb 2001 & $23 / 37$ & $15 / 35$ & & $6.33 \%$ & $1.45[0.92,2.29]$ \\
\hline Kasper 2006 & $159 / 243$ & $26 / 81$ & $\longrightarrow$ & $7.35 \%$ & $2.04[1.47,2.83]$ \\
\hline Lecrubier 2002 & $98 / 186$ & $80 / 189$ & $\rightarrow$ & $8.16 \%$ & $1.24[1,1.54]$ \\
\hline Montgomery 2000 & $55 / 123$ & $57 / 124$ & $\longrightarrow$ & $7.77 \%$ & $0.97[0.74,1.28]$ \\
\hline Philipp 1999 & $67 / 106$ & $22 / 47$ & $\rightarrow$ & $7.29 \%$ & $1.35[0.96,1.89]$ \\
\hline Witte 1995 & $34 / 48$ & $25 / 49$ & $\longrightarrow$ & $7.35 \%$ & $1.39[1,1.93]$ \\
\hline Subtotal $(95 \% \mathrm{Cl})$ & 987 & 771 & 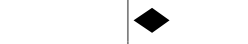 & $59.72 \%$ & $1.28[1.06,1.53]$ \\
\hline \multicolumn{6}{|c|}{ Total events: 553 (Hypericum), 332 (Placebo) } \\
\hline \multicolumn{6}{|c|}{ Heterogeneity: Tau $^{2}=0.04 ; \mathrm{Chi}^{2}=20.32, \mathrm{df}=7(\mathrm{P}=0) ; \mathrm{I}^{2}=65.55 \%$} \\
\hline Total $(95 \% \mathrm{Cl})$ & 1456 & 1250 & & $100 \%$ & $1.51[1.22,1.87]$ \\
\hline \multicolumn{6}{|c|}{ Total events: 767 (Hypericum), 436 (Placebo) } \\
\hline \multicolumn{6}{|c|}{ Heterogeneity: $\mathrm{Tau}^{2}=0.13 ; \mathrm{Chi}^{2}=69.13, \mathrm{df}=15(\mathrm{P}<0.0001) ; \mathrm{I}^{2}=78.3 \%$} \\
\hline \multicolumn{6}{|c|}{ Test for overall effect: $Z=3.77(P=0)$} \\
\hline Test for subgroup dif & licable & & & & \\
\hline
\end{tabular}

St John's wort for major depression (Review) 
Analysis 1.3. Comparison 1 Hypericum mono-preparations vs. placebo A. Dichotomous measures, Outcome 3 Responder - according to CGI (Clinical Global Impression Index at least "much improved").

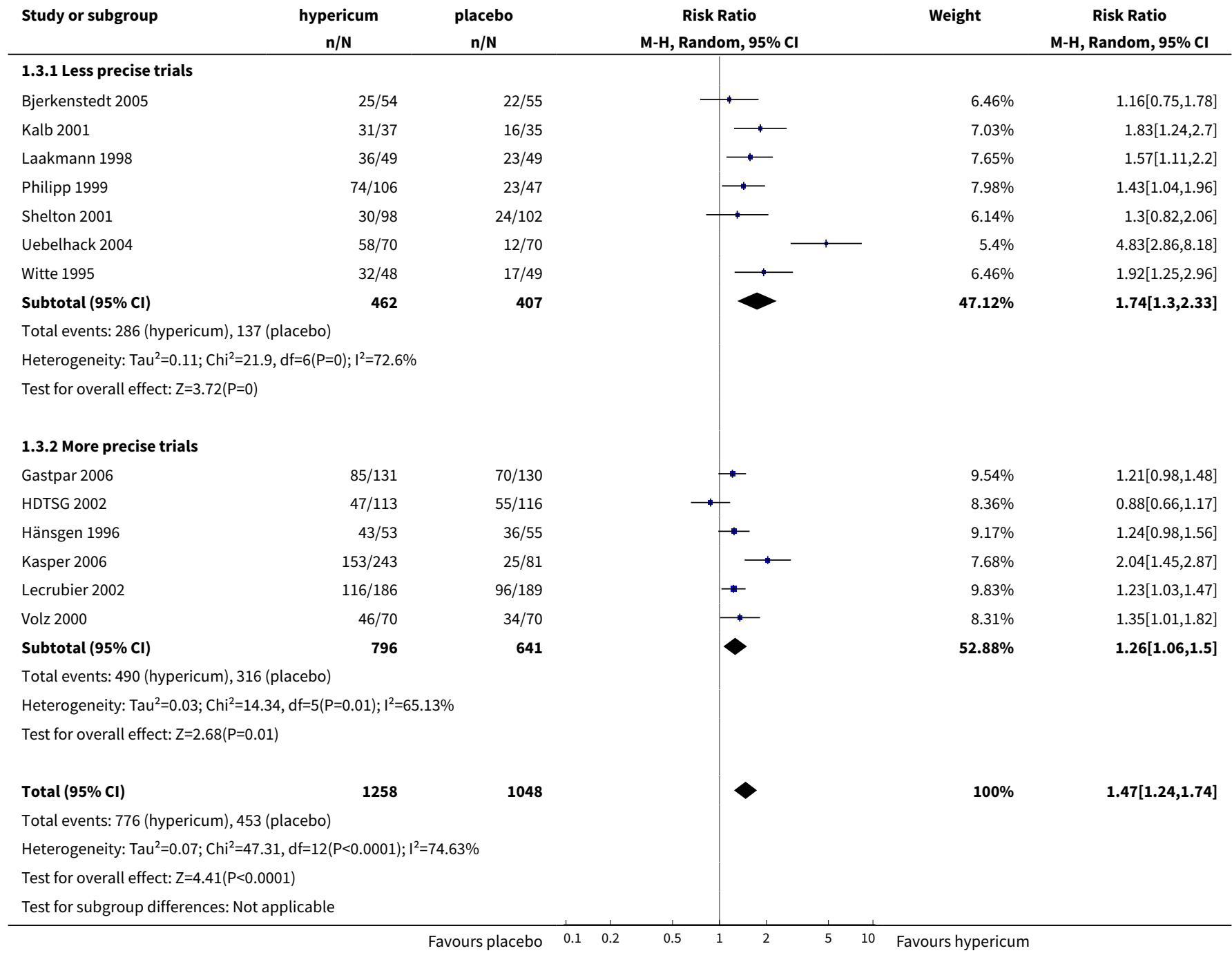

Analysis 1.4. Comparison 1 Hypericum mono-preparations vs. placebo A. Dichotomous measures, Outcome 4 Responder - grouped by extract.

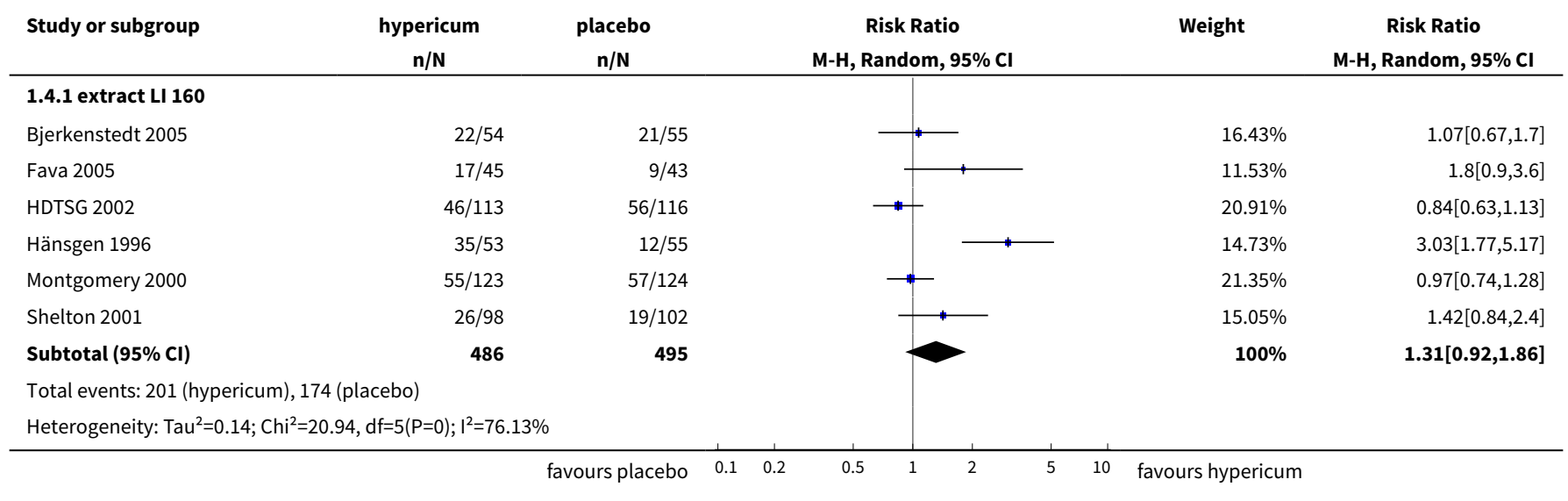

St John's wort for major depression (Review) 


\begin{tabular}{|c|c|c|c|c|c|}
\hline Study or subgroup & $\begin{array}{c}\text { hypericum } \\
\mathrm{n} / \mathrm{N} \\
\end{array}$ & $\begin{array}{c}\text { placebo } \\
n / N\end{array}$ & $\begin{array}{c}\text { Risk Ratio } \\
\text { M-H, Random, } 95 \% \text { CI }\end{array}$ & Weight & $\begin{array}{c}\text { Risk Ratio } \\
\text { M-H, Random, } 95 \% \mathrm{Cl}\end{array}$ \\
\hline \multicolumn{6}{|c|}{ Test for overall effect: $Z=1.47(P=0.14)$} \\
\hline \multicolumn{6}{|l|}{ 1.4.2 extract WS 5570} \\
\hline Kasper 2006 & $159 / 243$ & $26 / 81$ & 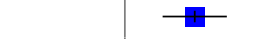 & $46.72 \%$ & $2.04[1.47,2.83]$ \\
\hline Lecrubier 2002 & $98 / 186$ & $80 / 189$ & & $53.28 \%$ & $1.24[1,1.54]$ \\
\hline Subtotal $(95 \% \mathrm{Cl})$ & 429 & 270 & & $100 \%$ & $1.57[0.96,2.56]$ \\
\hline \multicolumn{6}{|c|}{ Total events: 257 (hypericum), 106 (placebo) } \\
\hline \multicolumn{6}{|c|}{ Heterogeneity: $\mathrm{Tau}^{2}=0.11 ; \mathrm{Chi}^{2}=6.26, \mathrm{df}=1(\mathrm{P}=0.01) ; \mathrm{I}^{2}=84.02 \%$} \\
\hline \multicolumn{6}{|c|}{ Test for overall effect: $Z=1.79(P=0.07)$} \\
\hline \multicolumn{6}{|l|}{ 1.4.3 extract WS 5572} \\
\hline Kalb 2001 & $23 / 37$ & $15 / 35$ & & $51.35 \%$ & $1.45[0.92,2.29]$ \\
\hline Laakmann 1998 & $24 / 49$ & $16 / 49$ & & $48.65 \%$ & $1.5[0.92,2.46]$ \\
\hline Subtotal $(95 \% \mathrm{CI})$ & 86 & 84 & & $100 \%$ & $1.47[1.05,2.06]$ \\
\hline \multicolumn{6}{|c|}{ Total events: 47 (hypericum), 31 (placebo) } \\
\hline \multicolumn{6}{|c|}{ Heterogeneity: $\operatorname{Tau}^{2}=0 ; \mathrm{Chi}^{2}=0.01, \mathrm{df}=1(\mathrm{P}=0.92) ; \mathrm{I}^{2}=0 \%$} \\
\hline \multicolumn{6}{|c|}{ Test for overall effect: $Z=2.26(P=0.02)$} \\
\hline \multicolumn{6}{|l|}{ 1.4.4 extract STW3-VI } \\
\hline Gastpar 2006 & $71 / 131$ & $51 / 130$ & & $74.12 \%$ & $1.38[1.06,1.8]$ \\
\hline Uebelhack 2004 & $41 / 70$ & $4 / 70$ & & $25.88 \%$ & $10.25[3.88,27.09]$ \\
\hline Subtotal $(95 \% \mathrm{Cl})$ & 201 & 200 & & $100 \%$ & $3.59[0.41,31.56]$ \\
\hline \multicolumn{6}{|c|}{ Total events: 112 (hypericum), 55 (placebo) } \\
\hline \multicolumn{6}{|c|}{ Heterogeneity: $\operatorname{Tau}^{2}=2.33 ; \mathrm{Chi}^{2}=18.65, \mathrm{df}=1(\mathrm{P}<0.0001) ; \mathrm{I}^{2}=94.64 \%$} \\
\hline \multicolumn{6}{|c|}{ Test for overall effect: $Z=1.15(P=0.25)$} \\
\hline \multicolumn{6}{|l|}{ 1.4.5 other extracts } \\
\hline Bracher 2001 & $64 / 109$ & $48 / 109$ & 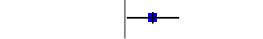 & $20.81 \%$ & $1.33[1.02,1.74]$ \\
\hline Moreno 2005 & $4 / 20$ & $11 / 26$ & - & $7.12 \%$ & $0.47[0.18,1.27]$ \\
\hline Philipp 1999 & $67 / 106$ & $22 / 47$ & $\longrightarrow$ & $19.01 \%$ & $1.35[0.96,1.89]$ \\
\hline Schrader 1998 & $45 / 80$ & $12 / 79$ & $\rightarrow$ & $13.77 \%$ & $3.7[2.12,6.46]$ \\
\hline Volz 2000 & $46 / 70$ & $34 / 70$ & $\longrightarrow$ & $20.07 \%$ & $1.35[1.01,1.82]$ \\
\hline Witte 1995 & $34 / 48$ & $25 / 49$ & $\longrightarrow$ & $19.22 \%$ & $1.39[1,1.93]$ \\
\hline Subtotal $(95 \% \mathrm{Cl})$ & 433 & 380 & & $100 \%$ & $1.45[1.08,1.93]$ \\
\hline \multicolumn{6}{|c|}{ Total events: 260 (hypericum), 152 (placebo) } \\
\hline \multicolumn{6}{|c|}{ Heterogeneity: $\mathrm{Tau}^{2}=0.08 ; \mathrm{Chi}^{2}=16.98, \mathrm{df}=5(\mathrm{P}=0) ; \mathrm{I}^{2}=70.56 \%$} \\
\hline Test for overall effect & & & & & \\
\hline
\end{tabular}

Analysis 1.5. Comparison 1 Hypericum mono-preparations vs. placebo A. Dichotomous measures, Outcome 5 Responder among studies from German-speaking countries and other studies.

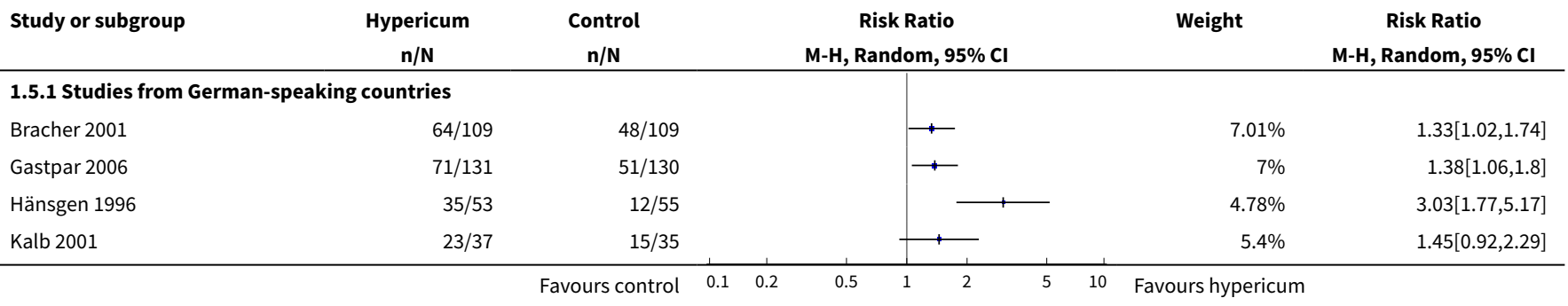




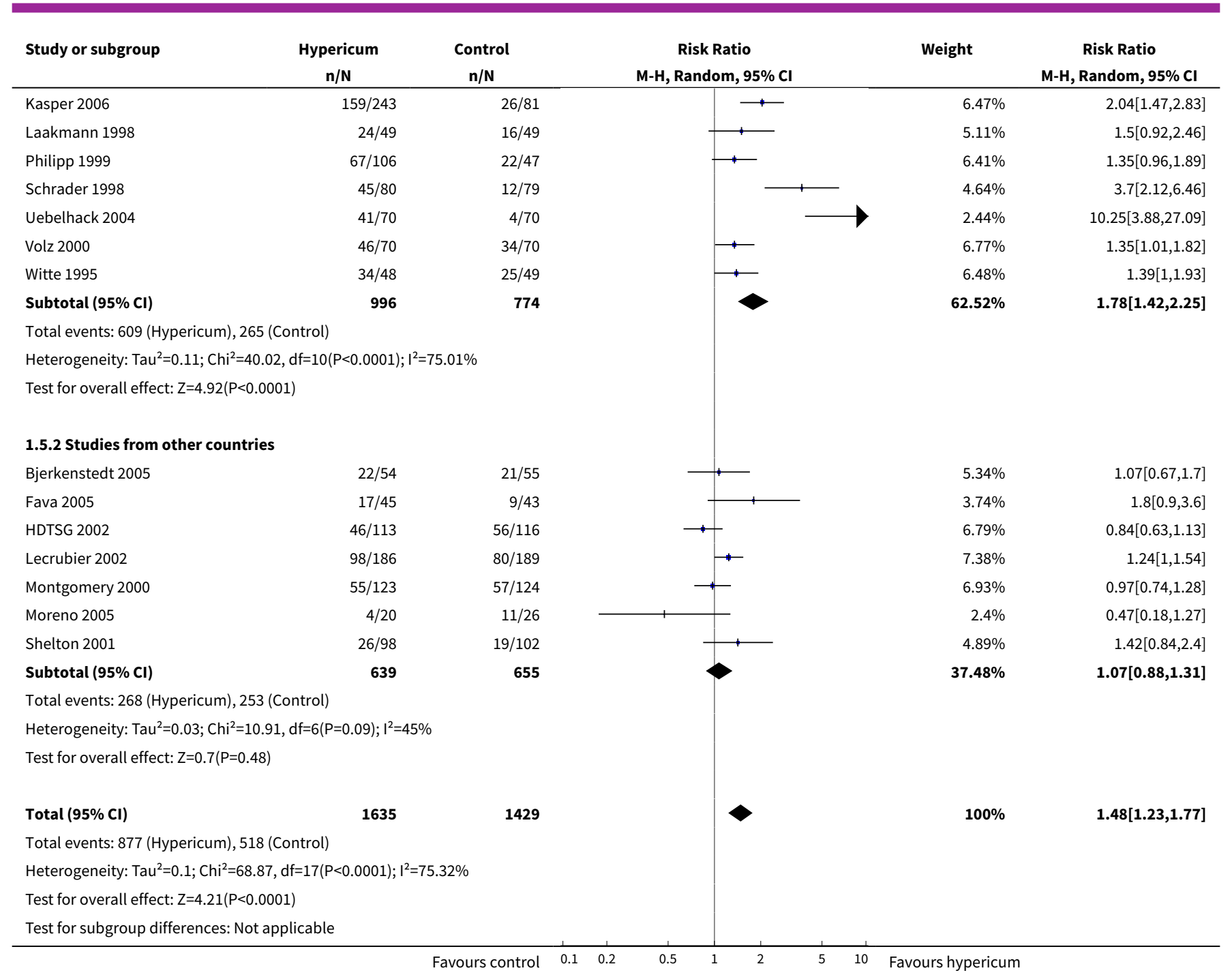

Analysis 1.6. Comparison 1 Hypericum mono-preparations vs. placebo A. Dichotomous measures, Outcome 6 Remission (HAMD score $<8$ or $<7$ ).

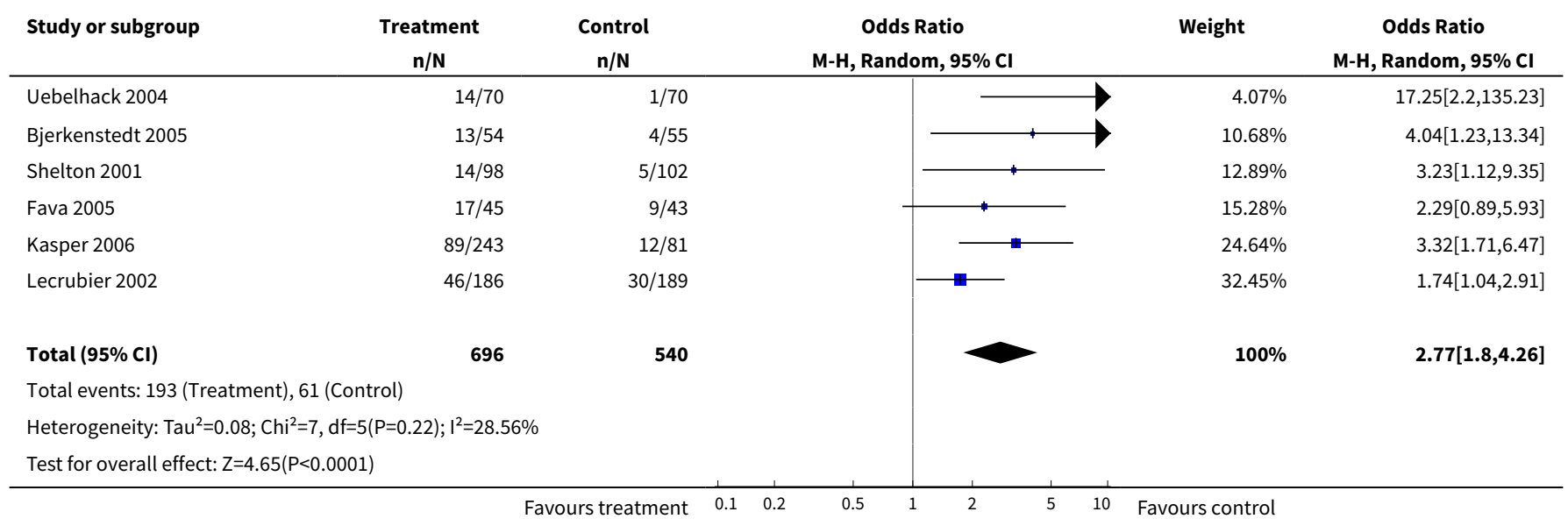


Comparison 2. Hypericum mono-preparations vs. placebo. B. Continuous measures

\begin{tabular}{|c|c|c|c|c|}
\hline Outcome or subgroup title & $\begin{array}{l}\text { No. of } \\
\text { studies }\end{array}$ & $\begin{array}{l}\text { No. of } \\
\text { partici- } \\
\text { pants }\end{array}$ & Statistical method & Effect size \\
\hline $\begin{array}{l}1 \text { Mean HAMD (Hamilton Rating Scale for } \\
\text { Depression) scores after therapy }\end{array}$ & 17 & 2871 & Mean Difference (IV, Random, 95\% CI) & $-3.04[-4.29,-1.78]$ \\
\hline $\begin{array}{l}2 \text { Mean HAMD (Hamilton Rating Scale for } \\
\text { Depression) scores after } 2 \text { to } 3 \text { weeks of } \\
\text { treatment }\end{array}$ & 13 & 2299 & Mean Difference (IV, Random, 95\% CI) & $-1.22[-2.07,-0.37]$ \\
\hline $\begin{array}{l}3 \text { Mean HAMD (Hamilton Rating Scale for } \\
\text { Depression) score after } 4 \text { weeks of treat- } \\
\text { ment }\end{array}$ & 11 & 1634 & Mean Difference (IV, Random, 95\% CI) & $-1.65[-2.78,-0.52]$ \\
\hline $\begin{array}{l}4 \text { Mean HAMD (Hamilton Rating Scale for } \\
\text { Depression) scores after } 6 \text { to } 8 \text { weeks of } \\
\text { treatment }\end{array}$ & 15 & 2578 & Mean Difference (IV, Random, 95\% CI) & $-2.97[-4.31,-1.63]$ \\
\hline $\begin{array}{l}5 \text { Difference HAMD (Hamilton Rating } \\
\text { Scale for Depression) baseline - end of } \\
\text { treatment }\end{array}$ & 17 & 2931 & Mean Difference (IV, Random, 95\% CI) & $-3.03[-4.67,-1.39]$ \\
\hline 6 MADRS after treatment & 3 & 640 & Mean Difference (IV, Random, 95\% CI) & $-3.86[-7.30,-0.42]$ \\
\hline $\begin{array}{l}7 \text { Difference MADRS baseline - end of } \\
\text { treatment }\end{array}$ & 4 & 1015 & Mean Difference (IV, Random, 95\% CI) & $-3.01[-4.88,-1.14]$ \\
\hline $\begin{array}{l}8 \text { Mean HAMD after treatment in stud- } \\
\text { ies from German-speaking countries and } \\
\text { other studies }\end{array}$ & 17 & 2871 & Mean Difference (IV, Random, 95\% CI) & $-3.04[-4.29,-1.78]$ \\
\hline $\begin{array}{l}\text { 8.1 Studies from German-speaking coun- } \\
\text { tries }\end{array}$ & 11 & 1720 & Mean Difference (IV, Random, 95\% CI) & $-4.29[-5.61,-2.97]$ \\
\hline 8.2 Studies from other countries & 6 & 1151 & Mean Difference (IV, Random, 95\% CI) & $-0.77[-1.74,0.20]$ \\
\hline $\begin{array}{l}9 \text { Mean Depression Scale von Zerssen (D- } \\
\text { S) after therapy/difference baseline - after } \\
\text { therapy }\end{array}$ & 4 & 411 & Mean Difference (IV, Random, 95\% CI) & $-3.72[-5.32,-2.12]$ \\
\hline 10 Various self-rating scales & 13 & 2330 & $\begin{array}{l}\text { Std. Mean Difference (IV, Random, 95\% } \\
\mathrm{Cl} \text { ) }\end{array}$ & $-0.47[-0.64,-0.30]$ \\
\hline $\begin{array}{l}10.1 \text { von Zerssen Depression Scale (D-S) } \\
\text { after treatment }\end{array}$ & 3 & 313 & $\begin{array}{l}\text { Std. Mean Difference (IV, Random, 95\% } \\
\mathrm{Cl} \text { ) }\end{array}$ & $-0.62[-1.11,-0.14]$ \\
\hline $\begin{array}{l}10.2 \text { von Zerssen Depression Scale (D-S) } \\
\text { difference baseline - after treatment }\end{array}$ & 2 & 170 & $\begin{array}{l}\text { Std. Mean Difference (IV, Random, 95\% } \\
\mathrm{CI} \text { ) }\end{array}$ & $-0.90[-2.02,0.22]$ \\
\hline 10.3 von Zerssen Adjective Mood Scale & 2 & 401 & $\begin{array}{l}\text { Std. Mean Difference (IV, Random, 95\% } \\
\mathrm{CI} \text { ) }\end{array}$ & $-0.61[-0.84,-0.37]$ \\
\hline 10.4 Beck Depression Inventory & 1 & 195 & $\begin{array}{l}\text { Std. Mean Difference (IV, Random, 95\% } \\
\mathrm{Cl} \text { ) }\end{array}$ & $-0.28[-0.56,0.00]$ \\
\hline
\end{tabular}

St John's wort for major depression (Review) 


\begin{tabular}{|c|c|c|c|c|}
\hline Outcome or subgroup title & $\begin{array}{l}\text { No. of } \\
\text { studies }\end{array}$ & $\begin{array}{l}\text { No. of } \\
\text { partici- } \\
\text { pants }\end{array}$ & Statistical method & Effect size \\
\hline $\begin{array}{l}\text { 10.5 Beck Depression Inventory differ- } \\
\text { ence baseline - after treatment }\end{array}$ & 2 & 553 & $\begin{array}{l}\text { Std. Mean Difference (IV, Random, 95\% } \\
\mathrm{Cl} \text { ) }\end{array}$ & $-0.31[-0.71,0.09]$ \\
\hline $\begin{array}{l}\text { 10.6 Zung Self Rating Depression Scale } \\
\text { (SDS) difference baseline - after treat- } \\
\text { ment }\end{array}$ & 1 & 146 & $\begin{array}{l}\text { Std. Mean Difference (IV, Random, 95\% } \\
\mathrm{Cl} \text { ) }\end{array}$ & $-0.37[-0.73,-0.02]$ \\
\hline $\begin{array}{l}\text { 10.7 Symptom Checklist (SCL-58) depres- } \\
\text { sion score }\end{array}$ & 1 & 375 & $\begin{array}{l}\text { Std. Mean Difference (IV, Random, 95\% } \\
\mathrm{Cl} \text { ) }\end{array}$ & $-0.16[-0.37,0.04]$ \\
\hline $\begin{array}{l}10.8 \text { von Zerssen Paranoid-Depressiv- } \\
\text { itäts-Skala }\end{array}$ & 1 & 177 & $\begin{array}{l}\text { Std. Mean Difference (IV, Random, 95\% } \\
\mathrm{Cl} \text { ) }\end{array}$ & $-0.18[-0.48,0.11]$ \\
\hline $\begin{array}{l}11 \text { Various self-rating scales in studies } \\
\text { from German-speaking countries and } \\
\text { other countries }\end{array}$ & 13 & 2330 & $\begin{array}{l}\text { Std. Mean Difference (IV, Random, 95\% } \\
\mathrm{Cl} \text { ) }\end{array}$ & $-0.47[-0.64,-0.30]$ \\
\hline $\begin{array}{l}11.1 \text { Studies from German-speaking } \\
\text { countries }\end{array}$ & 10 & 1531 & $\begin{array}{l}\text { Std. Mean Difference (IV, Random, 95\% } \\
\mathrm{Cl} \text { ) }\end{array}$ & $-0.57[-0.77,-0.37]$ \\
\hline 11.2 Studies from other countries & 3 & 799 & $\begin{array}{l}\text { Std. Mean Difference (IV, Random, 95\% } \\
\mathrm{Cl} \text { ) }\end{array}$ & $-0.17[-0.31,-0.04]$ \\
\hline
\end{tabular}

\section{Analysis 2.1. Comparison 2 Hypericum mono-preparations vs. placebo. B. Continuous measures, Outcome 1 Mean HAMD (Hamilton Rating Scale for Depression) scores after therapy.}

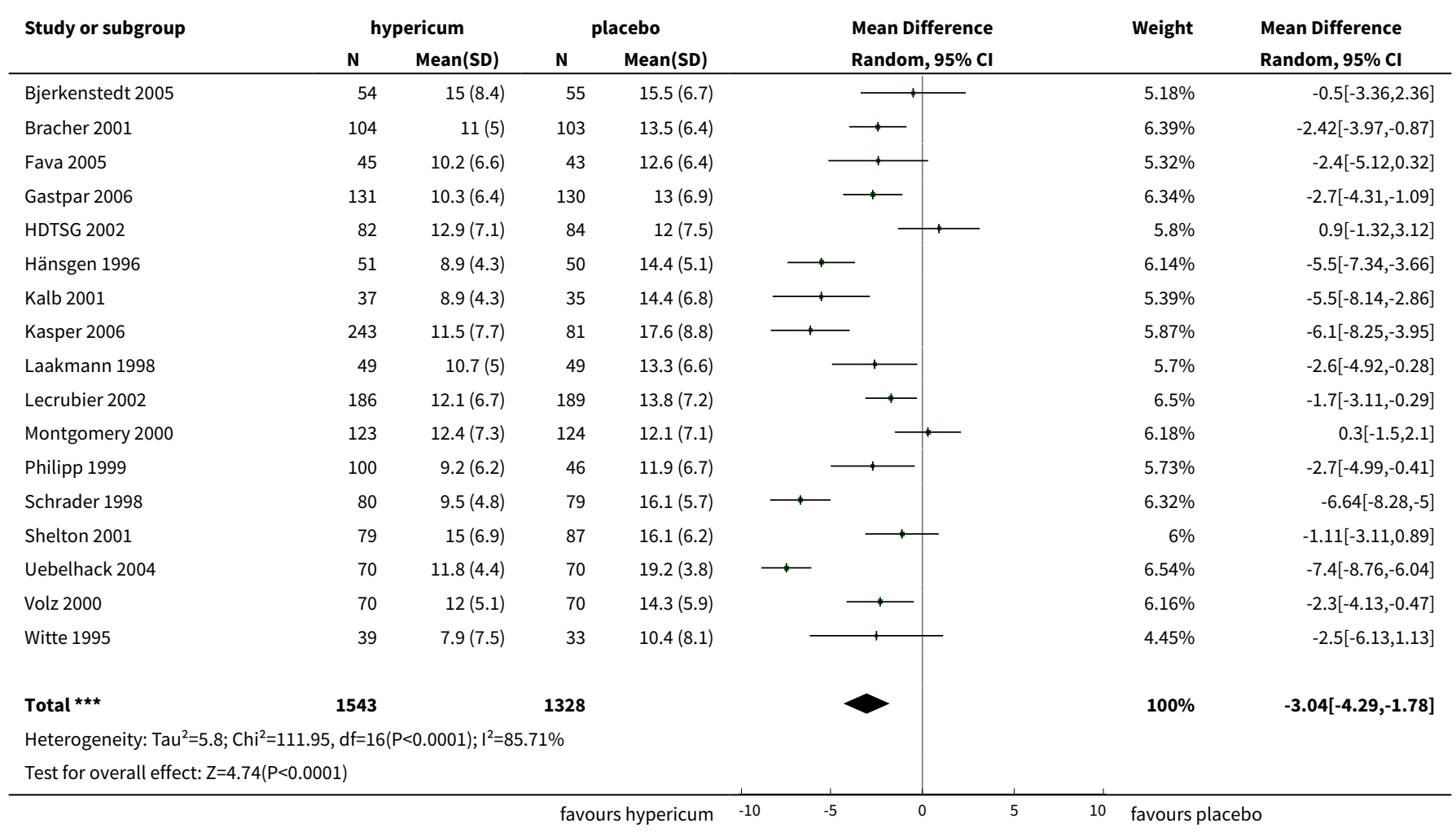


Analysis 2.2. Comparison 2 Hypericum mono-preparations vs. placebo. B. Continuous measures, Outcome 2 Mean HAMD (Hamilton Rating Scale for Depression) scores after 2 to 3 weeks of treatment.

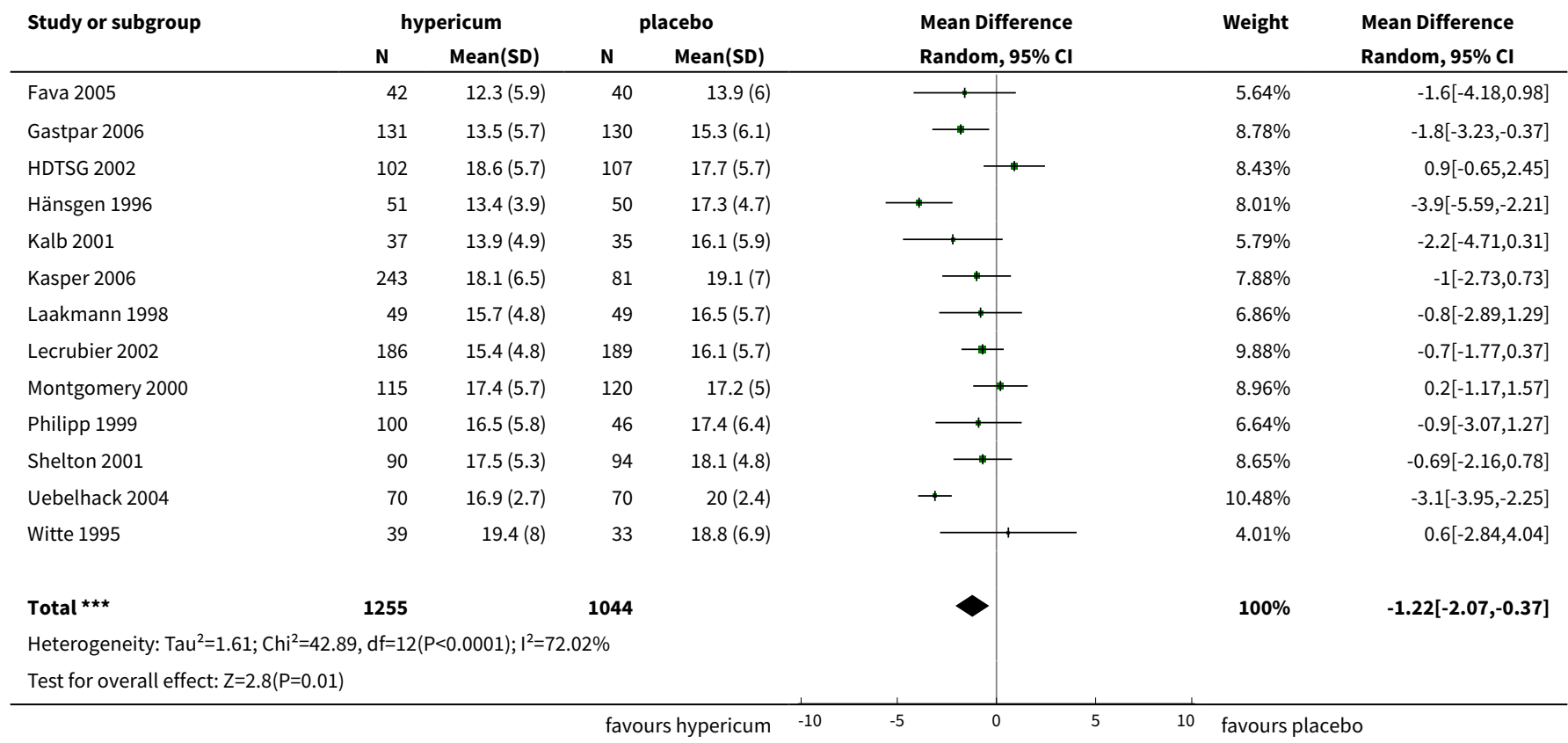

Analysis 2.3. Comparison 2 Hypericum mono-preparations vs. placebo. B. Continuous measures, Outcome 3 Mean HAMD (Hamilton Rating Scale for Depression) score after 4 weeks of treatment.

\begin{tabular}{|c|c|c|c|c|c|c|c|}
\hline \multirow{3}{*}{$\begin{array}{l}\text { Study or subgroup } \\
\text { Bjerkenstedt } 2005\end{array}$} & \multicolumn{2}{|c|}{ hypericum } & \multicolumn{2}{|c|}{ placebo } & \multirow{2}{*}{$\begin{array}{l}\text { Mean Difference } \\
\text { Random, } 95 \% \mathrm{Cl}\end{array}$} & \multirow[t]{2}{*}{ Weight } & \multirow{2}{*}{$\begin{array}{l}\text { Mean Difference } \\
\text { Random, } 95 \% \mathrm{Cl}\end{array}$} \\
\hline & $\mathbf{N}$ & Mean(SD) & $\mathbf{N}$ & Mean(SD) & & & \\
\hline & 54 & $15(8.4)$ & 55 & $15.5(6.7)$ & $\rightarrow$ & $7.37 \%$ & $-0.5[-3.36,2.36]$ \\
\hline Fava 2005 & 35 & $11.5(6.9)$ & 35 & $13.9(7.6)$ & - & $6.16 \%$ & $-2.4[-5.8,1]$ \\
\hline HDTSG 2002 & 97 & $16.9(7.1)$ & 99 & $15.9(6.5)$ & - & $9.97 \%$ & $1[-0.91,2.91]$ \\
\hline Hänsgen 1996 & 51 & $8.9(4.3)$ & 50 & $14.4(5.1)$ & & $10.17 \%$ & $-5.5[-7.34,-3.66]$ \\
\hline Kalb 2001 & 37 & $11.1(4.5)$ & 35 & $14.6(5.9)$ & & $8.46 \%$ & $-3.5[-5.93,-1.07]$ \\
\hline Lecrubier 2002 & 186 & $13.5(6.1)$ & 189 & $14.2(6.4)$ & 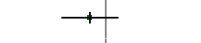 & $11.86 \%$ & $-0.7[-1.97,0.57]$ \\
\hline Montgomery 2000 & 108 & $13.1(5.7)$ & 115 & $13.5(6.1)$ & + & $11.04 \%$ & $-0.4[-1.95,1.15]$ \\
\hline Philipp 1999 & 100 & $12.3(5.9)$ & 46 & $14.2(7)$ & & $8.75 \%$ & $-1.9[-4.23,0.43]$ \\
\hline Shelton 2001 & 83 & $16(6)$ & 89 & $16.9(5.3)$ & - & $10.58 \%$ & $-0.83[-2.53,0.87]$ \\
\hline Witte 1995 & 39 & $12(6.6)$ & 33 & $14.3(6.8)$ & - & $6.77 \%$ & $-2.3[-5.41,0.81]$ \\
\hline \multicolumn{8}{|c|}{ Heterogeneity: $\operatorname{Tau}^{2}=2.38 ; \mathrm{Chi}^{2}=32.58, \mathrm{df}=10(\mathrm{P}=0) ; \mathrm{I}^{2}=69.3 \%$} \\
\hline \multicolumn{3}{|c|}{ Test for overall effect: $Z=2.86(P=0)$} & & & & & \\
\hline
\end{tabular}

St John's wort for major depression (Review) 
Analysis 2.4. Comparison 2 Hypericum mono-preparations vs. placebo. B. Continuous measures, Outcome 4 Mean HAMD (Hamilton Rating Scale for Depression) scores after 6 to 8 weeks of treatment.

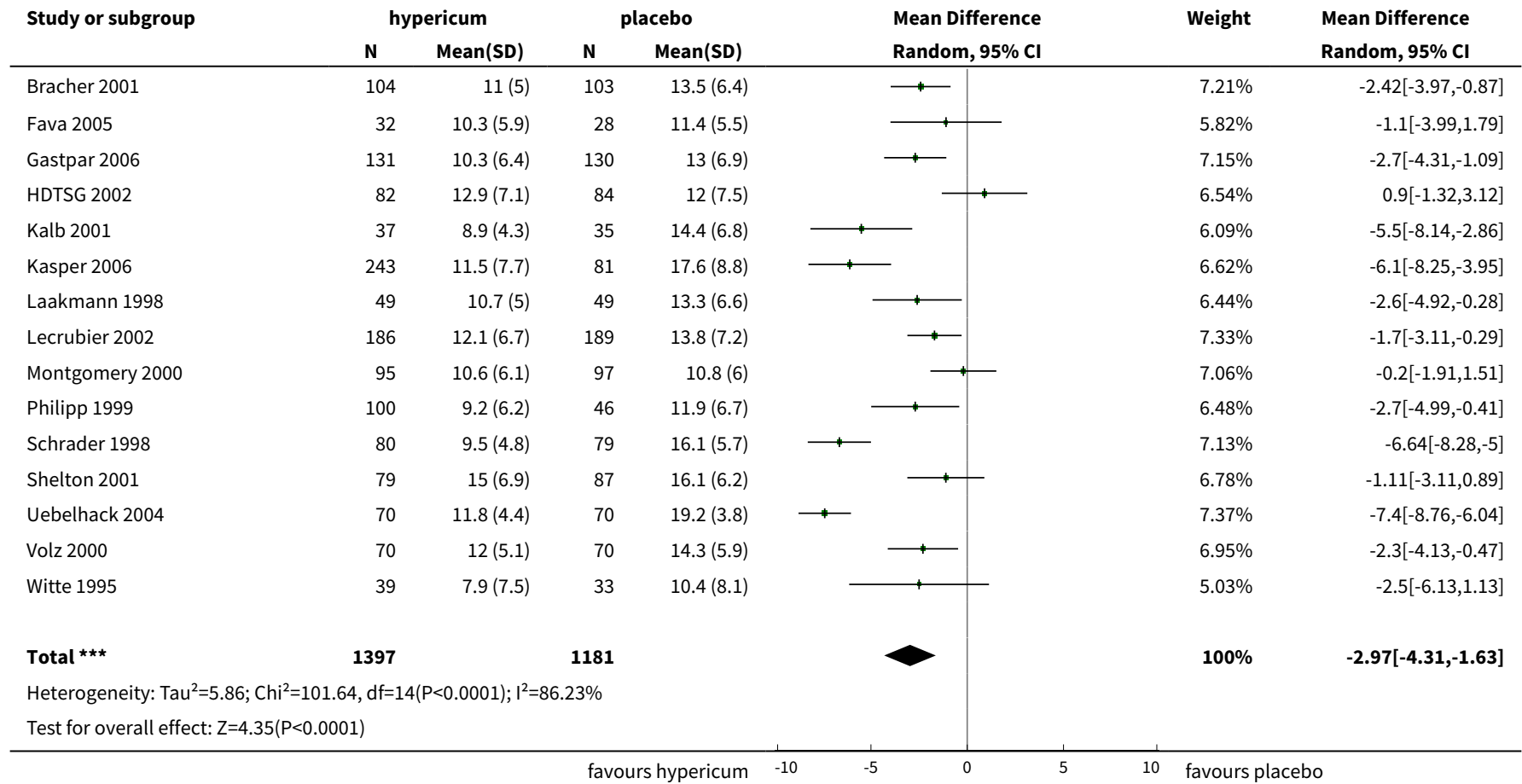

Analysis 2.5. Comparison 2 Hypericum mono-preparations vs. placebo. B. Continuous measures, Outcome 5 Difference HAMD (Hamilton Rating Scale for Depression) baseline - end of treatment.

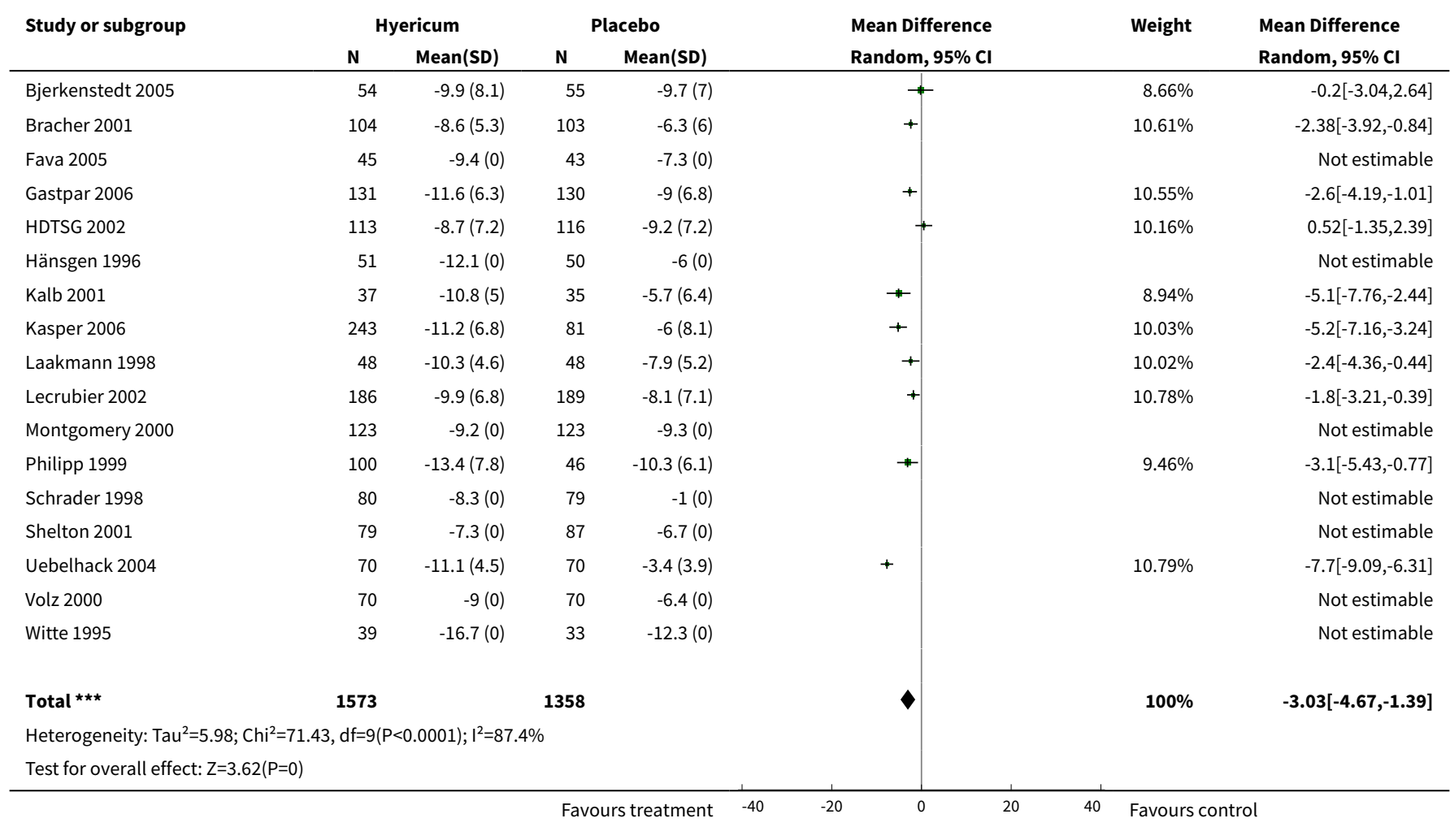

St John's wort for major depression (Review) 
Analysis 2.6. Comparison 2 Hypericum mono-preparations vs.

placebo. B. Continuous measures, Outcome 6 MADRS after treatment.

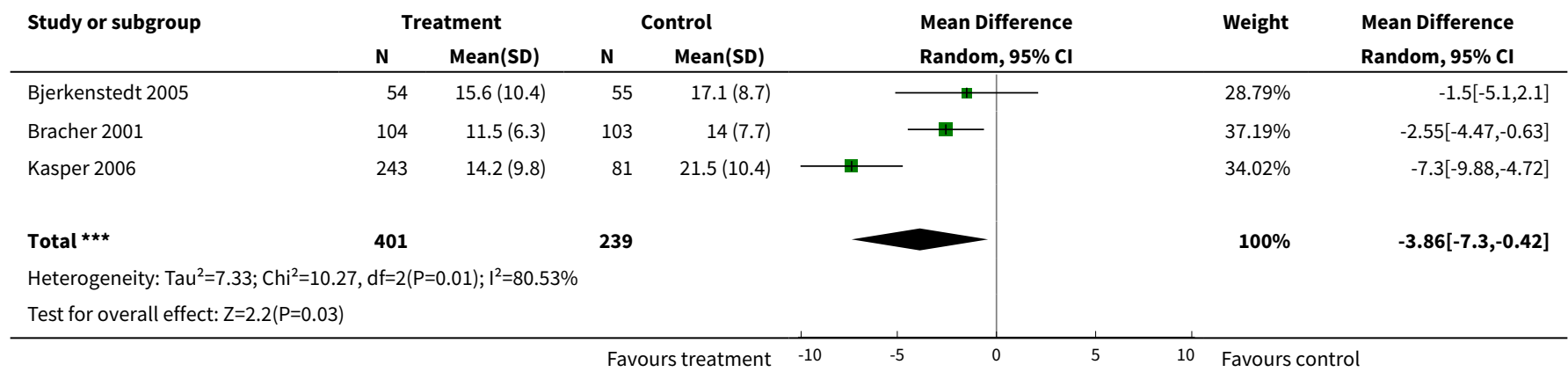

Analysis 2.7. Comparison 2 Hypericum mono-preparations vs. placebo. B. Continuous measures, Outcome 7 Difference MADRS baseline - end of treatment.

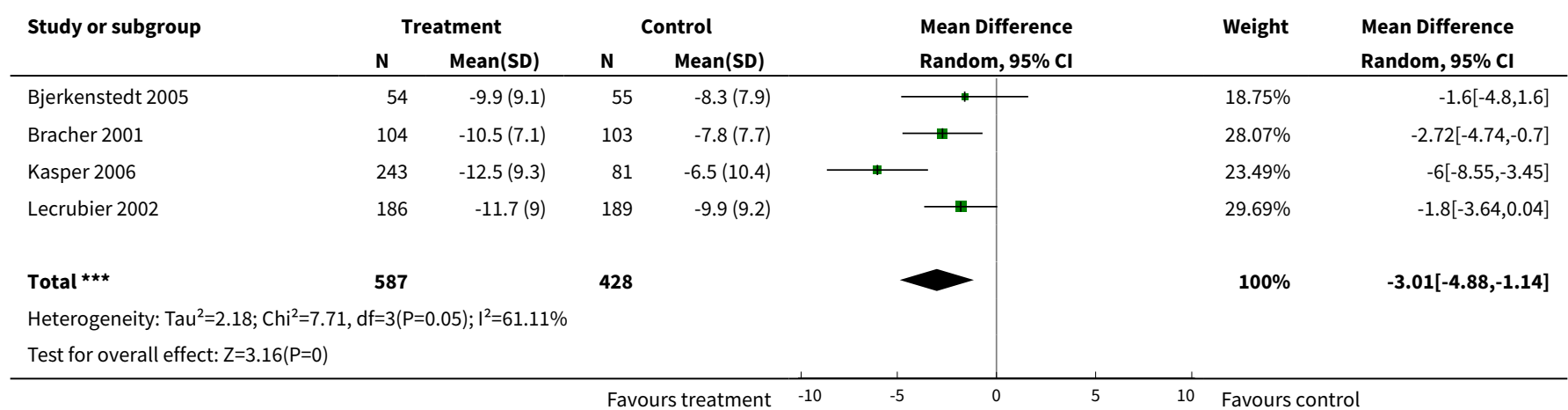

Analysis 2.8. Comparison 2 Hypericum mono-preparations vs. placebo. B. Continuous measures, Outcome 8 Mean HAMD after treatment in studies from German-speaking countries and other studies.

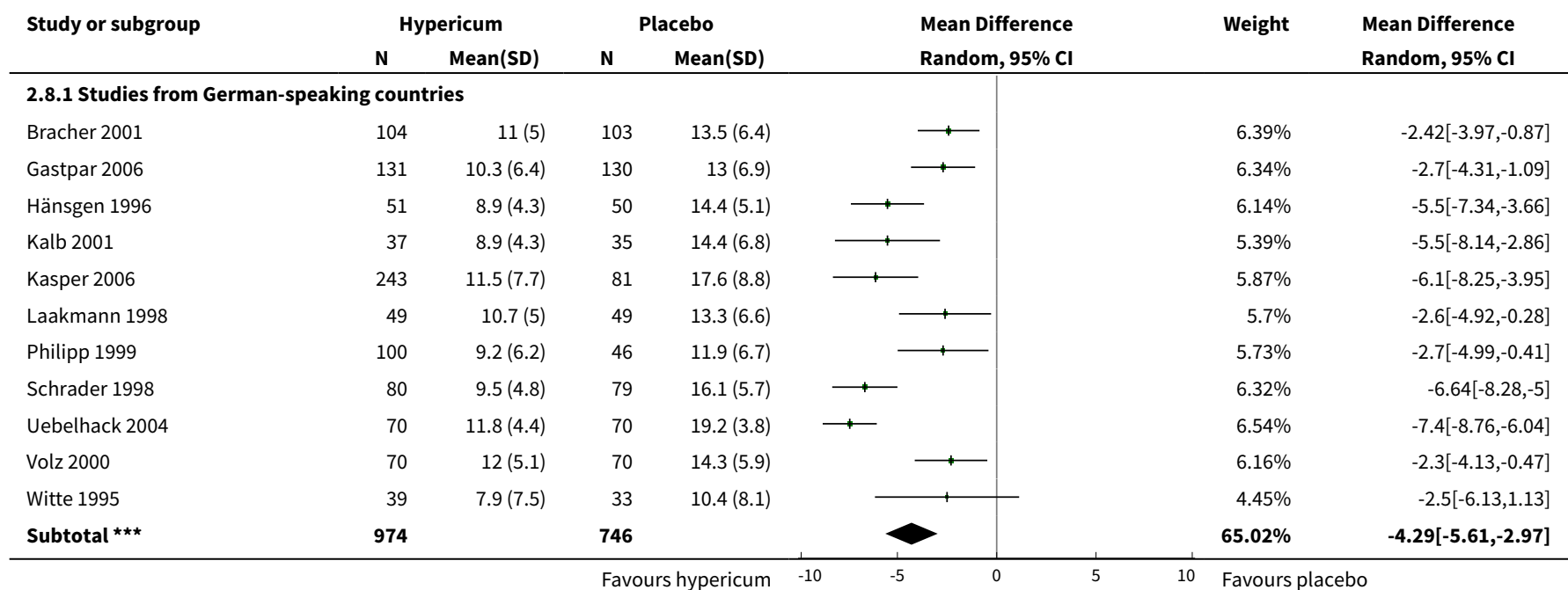




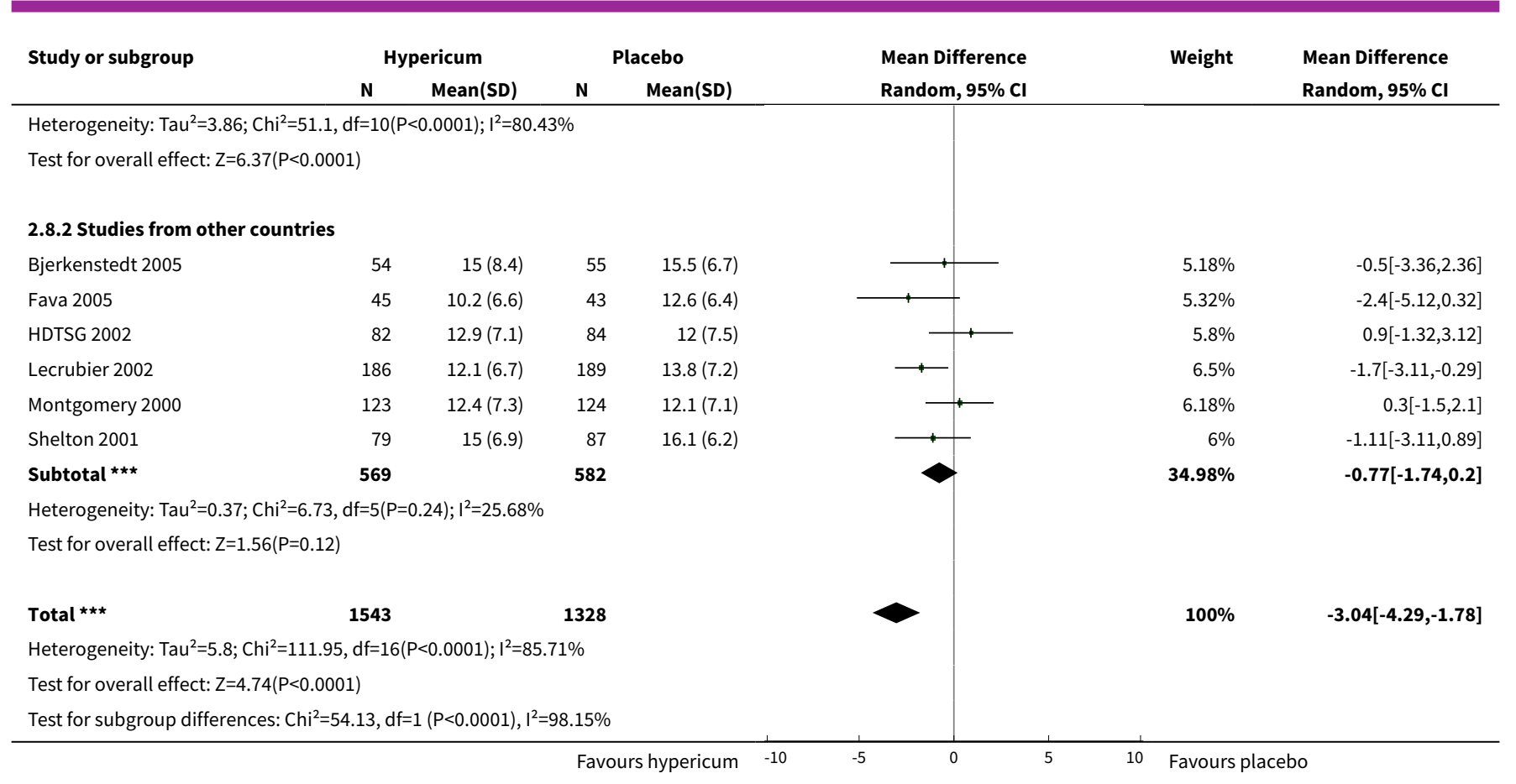

Analysis 2.9. Comparison 2 Hypericum mono-preparations vs. placebo. B. Continuous measures, Outcome 9 Mean Depression Scale von Zerssen (D-S) after therapy/difference baseline - after therapy.

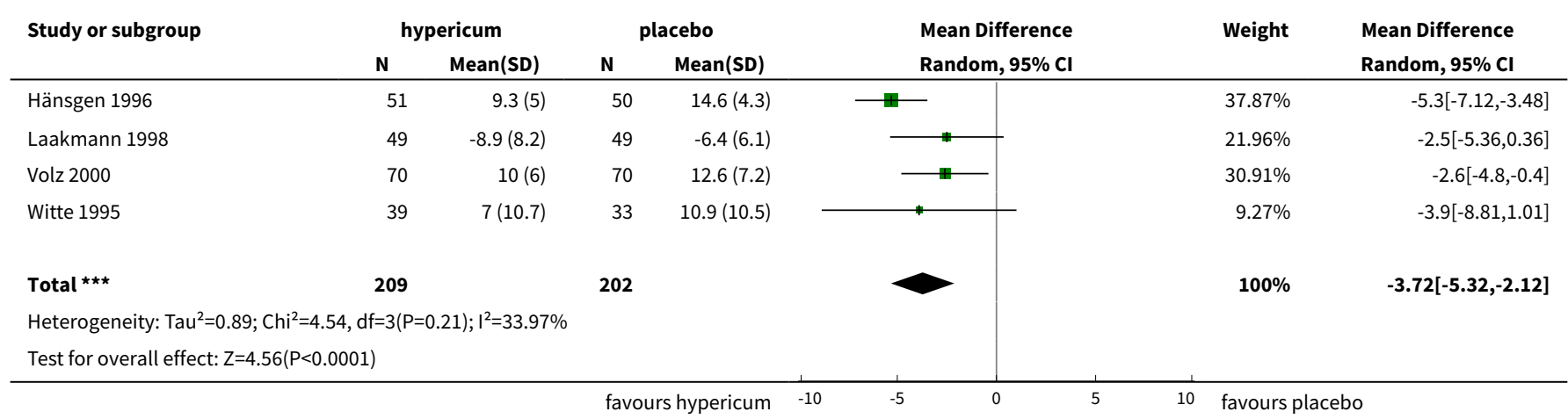

Analysis 2.10. Comparison 2 Hypericum mono-preparations vs. placebo. B. Continuous measures, Outcome 10 Various self-rating scales.

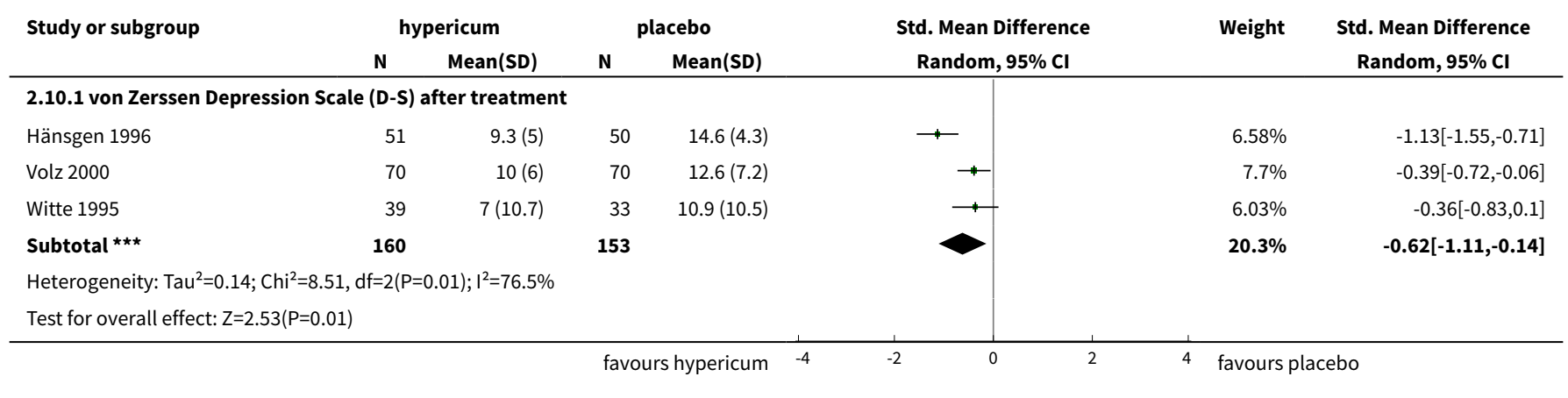

St John's wort for major depression (Review) 


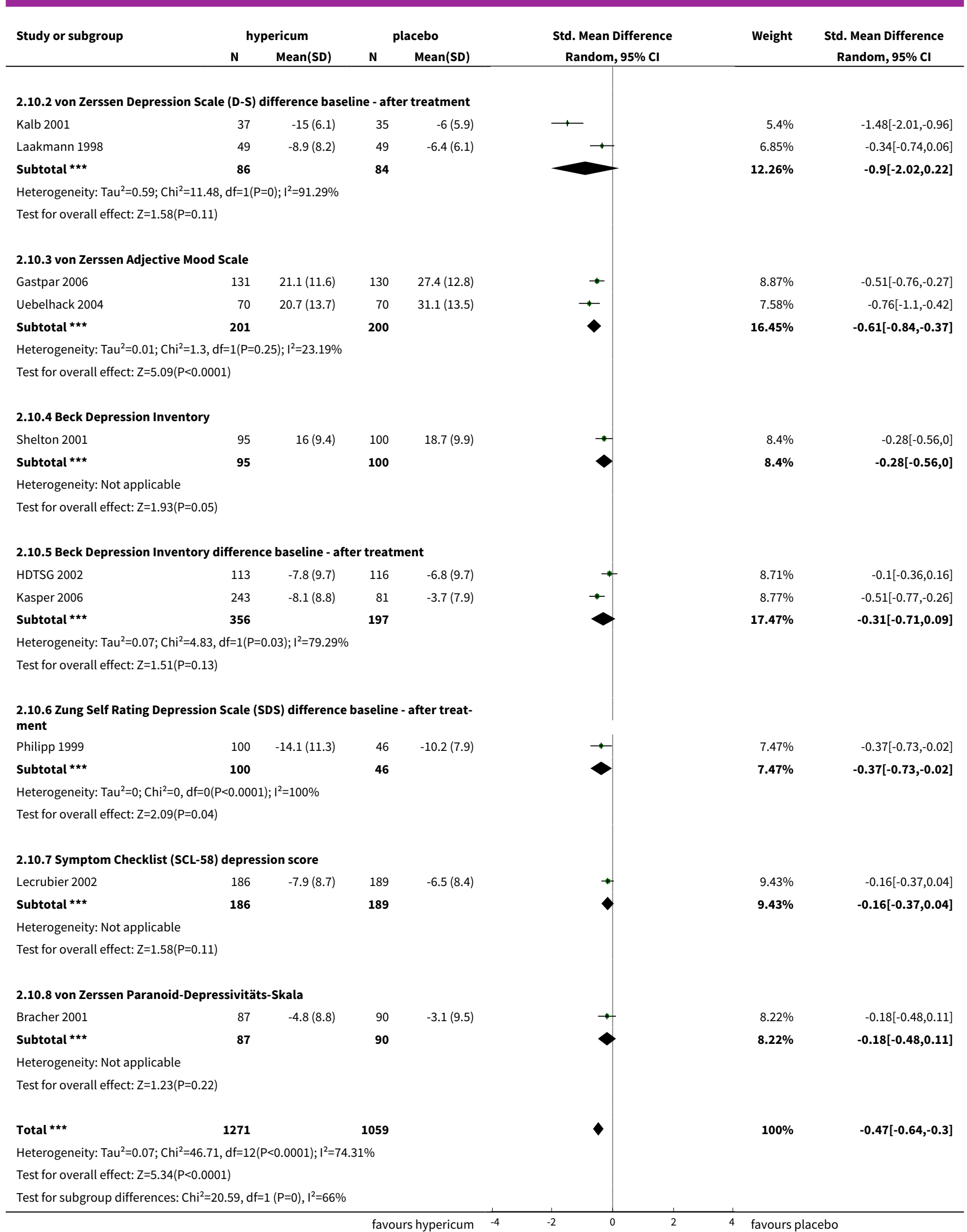

St John's wort for major depression (Review) 
Analysis 2.11. Comparison 2 Hypericum mono-preparations vs. placebo. B. Continuous measures, Outcome 11 Various self-rating scales in studies from German-speaking countries and other countries.

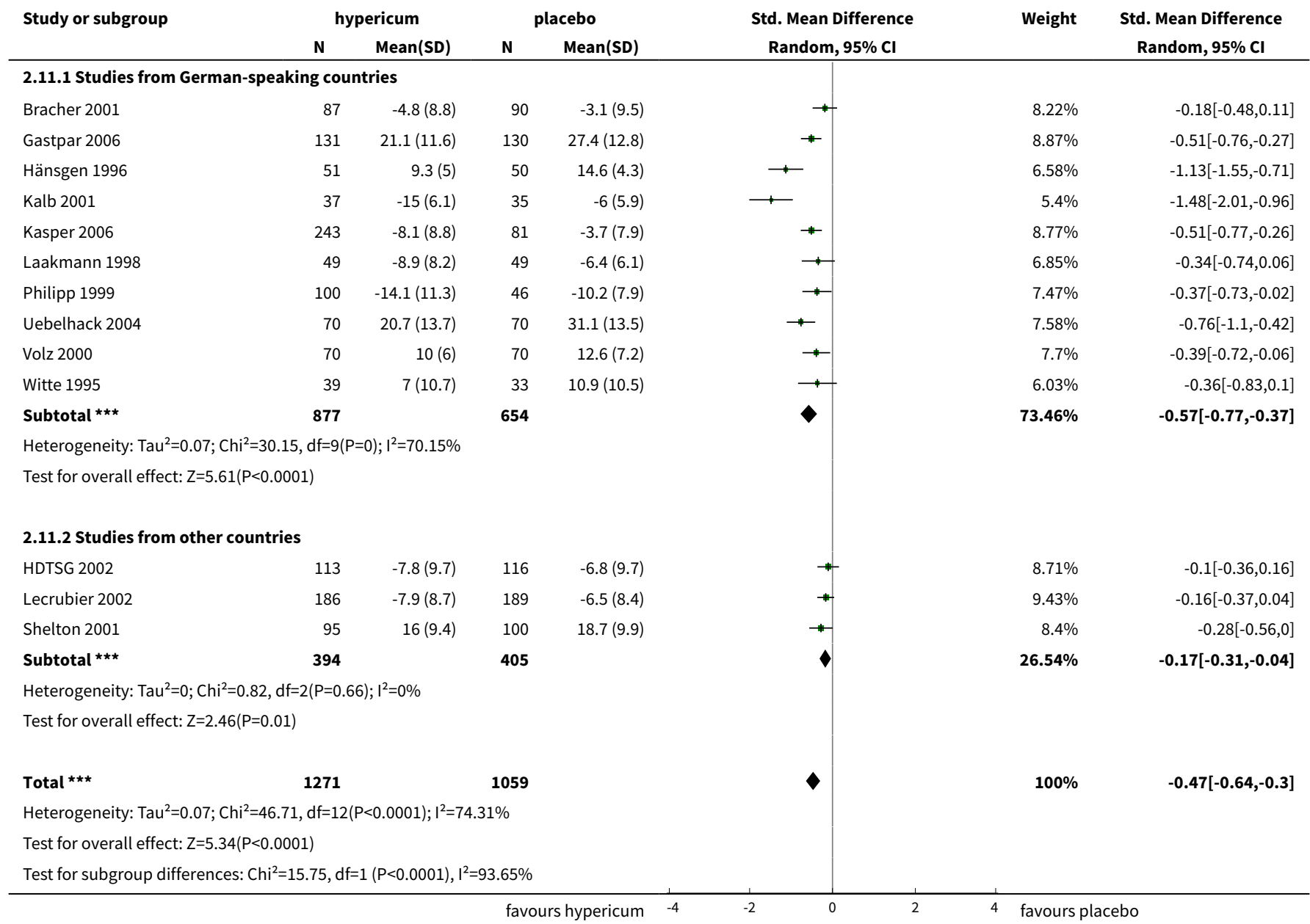

Comparison 3. Safety - Hypericum mono-preparations vs. placebo

\begin{tabular}{|c|c|c|c|c|}
\hline Outcome or subgroup title & $\begin{array}{l}\text { No. of } \\
\text { studies }\end{array}$ & $\begin{array}{l}\text { No. of } \\
\text { partici- } \\
\text { pants }\end{array}$ & Statistical method & Effect size \\
\hline $\begin{array}{l}1 \text { Number of patients discontinuing treat- } \\
\text { ment/dropping out for adverse effects - primary } \\
\text { analysis }\end{array}$ & 16 & 2784 & $\begin{array}{l}\text { Odds Ratio (M-H, Random, 95\% } \\
\mathrm{Cl} \text { ) }\end{array}$ & $0.92[0.45,1.88]$ \\
\hline 2 Number of patients dropping out & 16 & 2784 & $\begin{array}{l}\text { Odds Ratio (M-H, Random, 95\% } \\
\mathrm{Cl} \text { ) }\end{array}$ & $0.87[0.67,1.12]$ \\
\hline 3 Number of patients reporting adverse effects & 14 & 2496 & $\begin{array}{l}\text { Odds Ratio (M-H, Random, 95\% } \\
\mathrm{Cl} \text { ) }\end{array}$ & $0.98[0.78,1.23]$ \\
\hline
\end{tabular}


Analysis 3.1. Comparison 3 Safety - Hypericum mono-preparations vs. placebo, Outcome 1 Number of patients discontinuing treatment/dropping out for adverse effects - primary analysis.

\begin{tabular}{|c|c|c|c|c|c|}
\hline Study or subgroup & $\begin{array}{c}\text { hypericum } \\
n / N\end{array}$ & $\begin{array}{c}\text { placebo } \\
n / N\end{array}$ & $\begin{array}{c}\text { Odds Ratio } \\
\text { M-H, Random, } 95 \% \mathrm{Cl}\end{array}$ & Weight & $\begin{array}{c}\text { Odds Ratio } \\
\text { M-H, Random, } 95 \% \mathrm{Cl}\end{array}$ \\
\hline Bjerkenstedt 2005 & $4 / 57$ & $2 / 57$ & * & $17.07 \%$ & $2.08[0.36,11.81]$ \\
\hline Bracher 2001 & $0 / 109$ & $0 / 109$ & & & Not estimable \\
\hline Fava 2005 & $0 / 45$ & $0 / 43$ & & & Not estimable \\
\hline Gastpar 2006 & $4 / 131$ & $6 / 130$ & - & $31.06 \%$ & $0.65[0.18,2.36]$ \\
\hline HDTSG 2002 & $2 / 113$ & $3 / 116$ & & $15.78 \%$ & $0.68[0.11,4.14]$ \\
\hline Kalb 2001 & $0 / 37$ & $0 / 35$ & & & Not estimable \\
\hline Kasper 2006 & $6 / 250$ & $0 / 82$ & & $6.19 \%$ & $4.39[0.24,78.71]$ \\
\hline Laakmann 1998 & $0 / 49$ & $1 / 49$ & & $4.96 \%$ & $0.33[0.01,8.22]$ \\
\hline Lecrubier 2002 & $2 / 186$ & $2 / 189$ & & $13.29 \%$ & $1.02[0.14,7.29]$ \\
\hline Philipp 1999 & $0 / 106$ & $0 / 47$ & & & Not estimable \\
\hline Schrader 1998 & $0 / 80$ & $1 / 79$ & & $4.99 \%$ & $0.33[0.01,8.1]$ \\
\hline Uebelhack 2004 & $0 / 70$ & $0 / 70$ & & & Not estimable \\
\hline Volz 2000 & $0 / 70$ & $0 / 70$ & & & Not estimable \\
\hline Witte 1995 & $0 / 48$ & $0 / 49$ & & & Not estimable \\
\hline Total $(95 \% \mathrm{CI})$ & 1502 & 1282 & & $100 \%$ & $0.92[0.45,1.88]$ \\
\hline \multicolumn{6}{|c|}{ Total events: 19 (hypericum), 16 (placebo) } \\
\hline \multicolumn{6}{|c|}{ Heterogeneity: $\mathrm{Tau}^{2}=0 ; \mathrm{Chi}^{2}=3.19, \mathrm{df}=7(\mathrm{P}=0.87) ; \mathrm{I}^{2}=0 \%$} \\
\hline \multicolumn{6}{|c|}{ Test for overall effect: $Z=0.23(P=0.82)$} \\
\hline
\end{tabular}

Analysis 3.2. Comparison 3 Safety - Hypericum mono-preparations vs. placebo, Outcome 2 Number of patients dropping out.

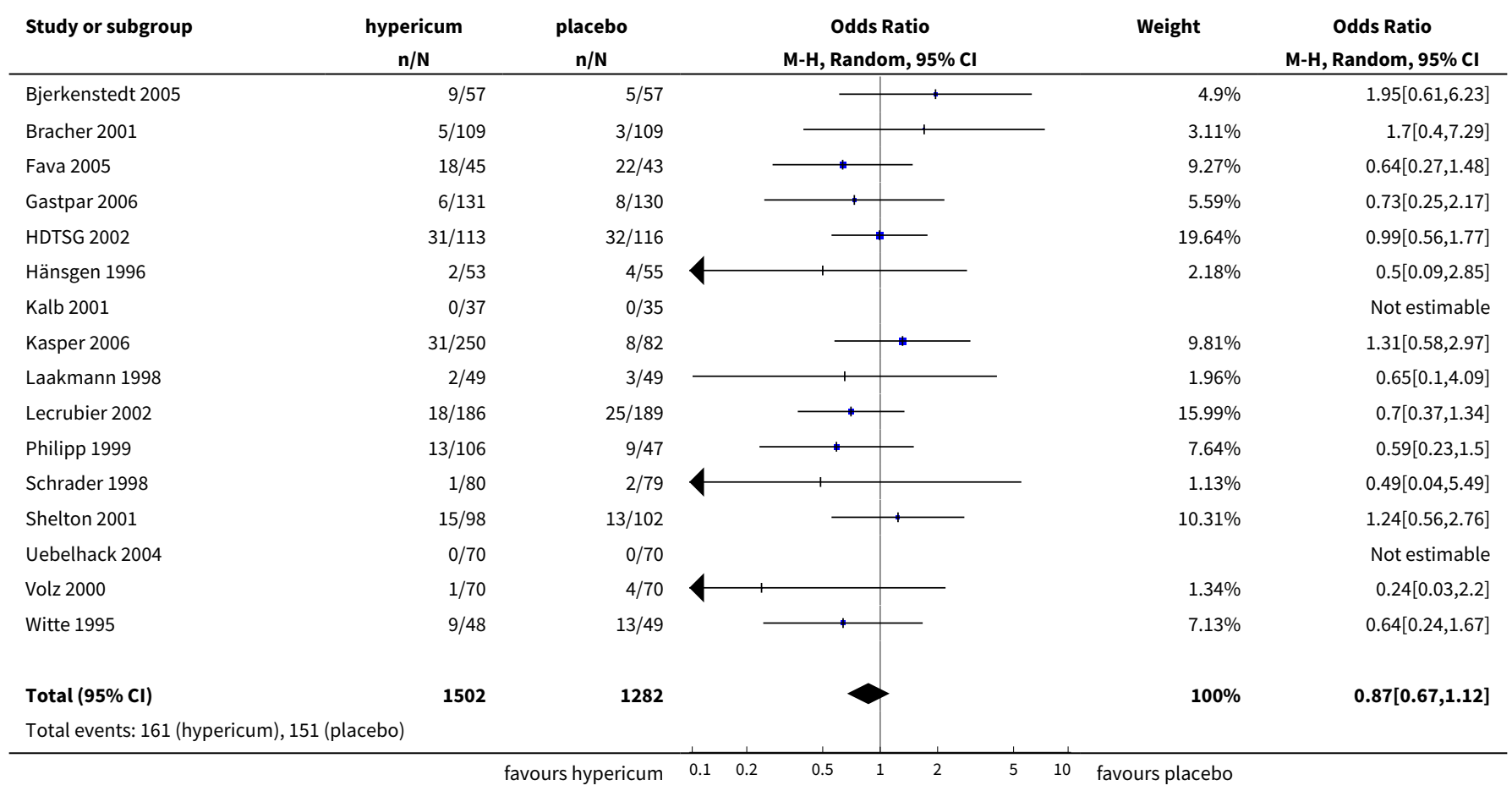




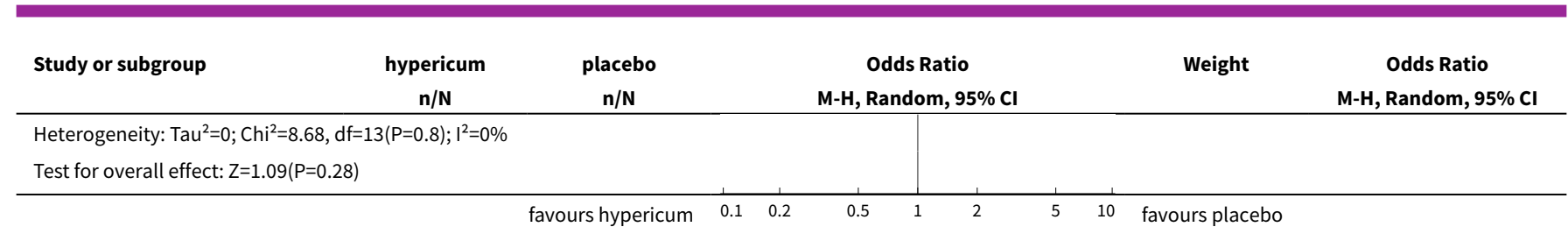

Analysis 3.3. Comparison 3 Safety - Hypericum mono-preparations vs. placebo, Outcome 3 Number of patients reporting adverse effects.

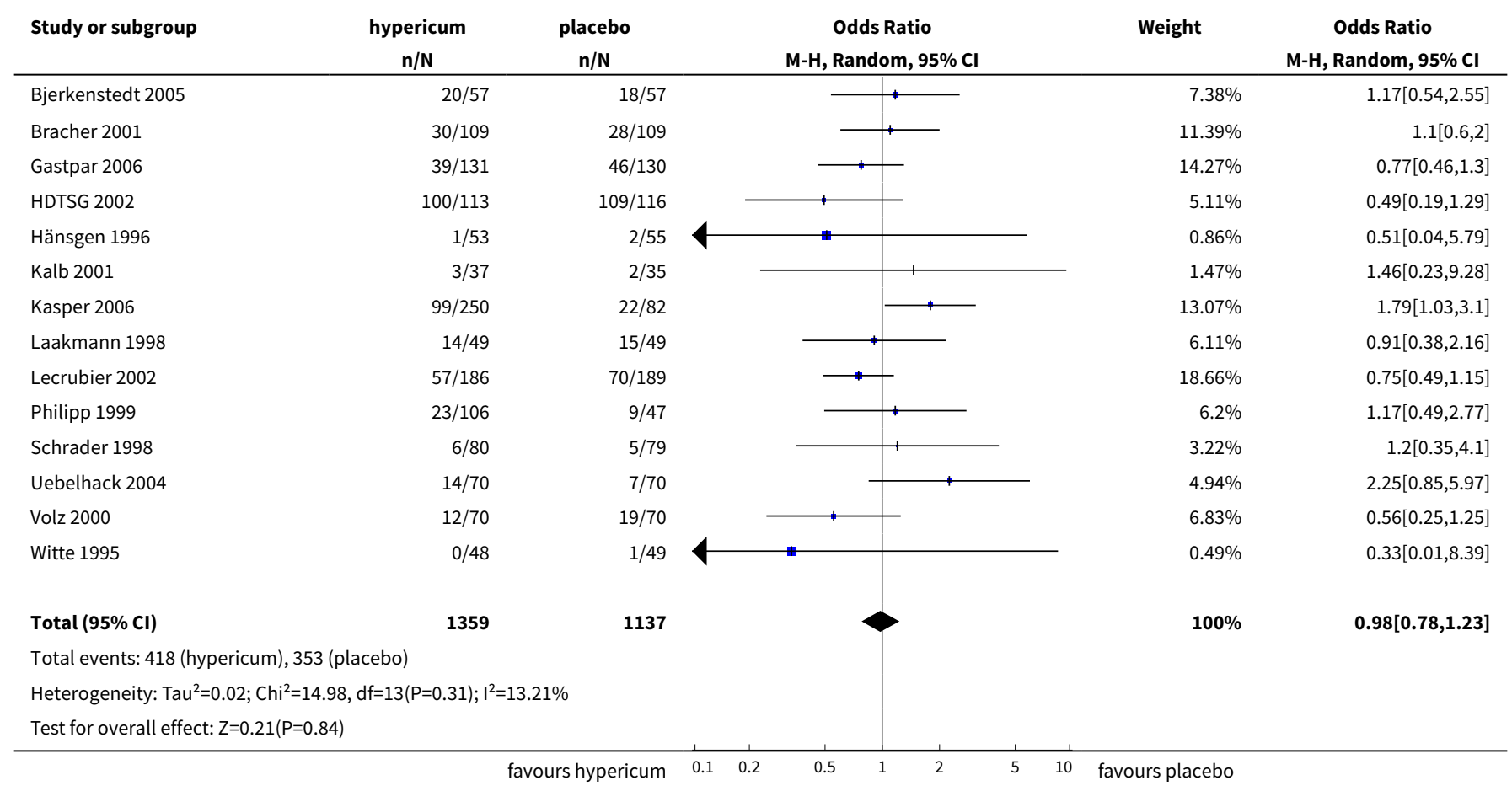

Comparison 4. Hypericum mono-preparations vs. standard antidepressants. A. Dichotomous measures

\begin{tabular}{lllll}
\hline Outcome or subgroup title & $\begin{array}{l}\text { No. of } \\
\text { studies }\end{array}$ & $\begin{array}{l}\text { No. of } \\
\text { partici- } \\
\text { pants }\end{array}$ & Statistical method & Effect size \\
\hline $\begin{array}{l}1 \text { Responder (intent to treat) } \\
\text { primary analysis }\end{array}$ & 17 & 2810 & Risk Ratio (M-H, Random, 95\% Cl) & $1.01[0.93,1.09]$ \\
\hline 1.1 vs. older antidepressants & 5 & 1016 & Risk Ratio (M-H, Random, 95\% Cl) & $1.02[0.90,1.15]$ \\
\hline 1.2 vs. SSRls & 12 & 1794 & Risk Ratio (M-H, Random, 95\% Cl) & $1.00[0.90,1.12]$ \\
\hline 2 Responder (per protocol) & 17 & 2306 & Risk Ratio (M-H, Random, 95\% Cl) & $0.96[0.88,1.05]$ \\
\hline 2.1 vs. older antidepressants & 5 & 854 & Risk Ratio (M-H, Random, 95\% Cl) & $0.93[0.78,1.11]$ \\
\hline 2.2 vs. SSRls & 12 & 1452 & Risk Ratio (M-H, Random, 95\% Cl) & $0.97[0.87,1.08]$ \\
\hline
\end{tabular}




\begin{tabular}{|c|c|c|c|c|}
\hline Outcome or subgroup title & $\begin{array}{l}\text { No. of } \\
\text { studies }\end{array}$ & $\begin{array}{l}\text { No. of } \\
\text { partici- } \\
\text { pants }\end{array}$ & Statistical method & Effect size \\
\hline $\begin{array}{l}3 \text { Responders according to CGI } \\
\text { (Clinical Global Impression In- } \\
\text { dex at least "much improved") }\end{array}$ & 12 & 2234 & Risk Ratio (M-H, Random, 95\% Cl) & $1.01[0.94,1.09]$ \\
\hline $3.1 \mathrm{vs.} \mathrm{older} \mathrm{antidepressants}$ & 4 & 692 & Risk Ratio (M-H, Random, 95\% Cl) & $0.97[0.87,1.09]$ \\
\hline 3.2 vs. newer antidepressants & 8 & 1542 & Risk Ratio (M-H, Random, 95\% Cl) & $1.03[0.92,1.15]$ \\
\hline $\begin{array}{l}4 \text { Responder among studies } \\
\text { from German-speaking studies } \\
\text { and other studies }\end{array}$ & 17 & 2769 & Risk Ratio (M-H, Random, 95\% Cl) & $1.00[0.93,1.09]$ \\
\hline $\begin{array}{l}4.1 \text { Studies from German-speak- } \\
\text { ing countries }\end{array}$ & 9 & 1952 & Risk Ratio (M-H, Random, 95\% Cl) & $1.04[0.96,1.13]$ \\
\hline 4.2 Studies from other countries & 8 & 817 & Risk Ratio (M-H, Random, 95\% Cl) & $0.90[0.76,1.06]$ \\
\hline 5 Remission (HAMD score $<8$ ) & 4 & 685 & Risk Ratio (M-H, Random, 95\% Cl) & $1.24[1.02,1.50]$ \\
\hline $5.1 \mathrm{vs.} \mathrm{older} \mathrm{antidepressants}$ & 0 & 0 & Risk Ratio (M-H, Random, 95\% Cl) & $0.0[0.0,0.0]$ \\
\hline 5.2 vs. SSRIs & 4 & 685 & Risk Ratio (M-H, Random, 95\% Cl) & $1.24[1.02,1.50]$ \\
\hline
\end{tabular}

Analysis 4.1. Comparison 4 Hypericum mono-preparations vs. standard antidepressants.

A. Dichotomous measures, Outcome 1 Responder (intent to treat) - primary analysis.

\begin{tabular}{|c|c|c|c|c|c|}
\hline Study or subgroup & $\begin{array}{c}\text { hypericum } \\
\mathrm{n} / \mathrm{N}\end{array}$ & $\begin{array}{c}\text { standard } \\
n / N\end{array}$ & $\begin{array}{c}\text { Risk Ratio } \\
\text { M-H, Random, } 95 \% \mathrm{CI}\end{array}$ & Weight & $\begin{array}{c}\text { Risk Ratio } \\
\text { M-H, Random, } 95 \% \mathrm{CI}\end{array}$ \\
\hline \multicolumn{6}{|c|}{ 4.1.1 vs. older antidepressants } \\
\hline Harrer 1993 & $27 / 51$ & $28 / 51$ & $\longrightarrow$ & $4.34 \%$ & $0.96[0.67,1.38]$ \\
\hline Philipp 1999 & $76 / 106$ & $70 / 110$ & + & $12.2 \%$ & $1.13[0.94,1.36]$ \\
\hline Vorbach 1997 & $36 / 107$ & $41 / 102$ & $\longrightarrow$ & $4.4 \%$ & $0.84[0.59,1.2]$ \\
\hline Wheatley 1997 & $40 / 87$ & $42 / 78$ & $\longrightarrow$ & $5.68 \%$ & $0.85[0.63,1.16]$ \\
\hline Woelk 2000 & $68 / 157$ & $67 / 167$ & $\rightarrow$ & $7.55 \%$ & $1.08[0.83,1.4]$ \\
\hline Subtotal $(95 \% \mathrm{Cl})$ & 508 & 508 & 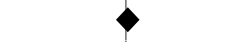 & $34.18 \%$ & $1.02[0.9,1.15]$ \\
\hline \multicolumn{6}{|c|}{ Total events: 247 (hypericum), 248 (standard) } \\
\hline \multicolumn{6}{|c|}{ Heterogeneity: $\mathrm{Tau}^{2}=0 ; \mathrm{Ch}^{2}=3.97, \mathrm{df}=4(\mathrm{P}=0.41) ; \mathrm{I}^{2}=0 \%$} \\
\hline \multicolumn{6}{|c|}{ Test for overall effect: $Z=0.3(P=0.77)$} \\
\hline \multicolumn{6}{|l|}{ 4.1.2 vs. SSRIs } \\
\hline Behnke 2002 & $16 / 35$ & $21 / 35$ & & $2.88 \%$ & $0.76[0.49,1.2]$ \\
\hline Bjerkenstedt 2005 & $22 / 54$ & $20 / 54$ & + & $2.63 \%$ & $1.1[0.68,1.77]$ \\
\hline Brenner 2000 & $7 / 15$ & $6 / 15$ & 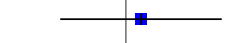 & $0.92 \%$ & $1.17[0.51,2.66]$ \\
\hline Fava 2005 & $17 / 45$ & $14 / 47$ & + & $1.81 \%$ & $1.27[0.71,2.26]$ \\
\hline Gastpar 2005 & $70 / 123$ & $72 / 118$ & + & $10.21 \%$ & $0.93[0.76,1.15]$ \\
\hline Gastpar 2006 & $71 / 131$ & $71 / 127$ & $\rightarrow$ & $9.57 \%$ & $0.97[0.78,1.21]$ \\
\hline Harrer 1999 & $50 / 77$ & $57 / 84$ & $\rightarrow$ & $9.57 \%$ & $0.96[0.77,1.19]$ \\
\hline HDTSG 2002 & $46 / 113$ & $55 / 109$ & $\rightarrow$ & $6.24 \%$ & $0.81[0.6,1.08]$ \\
\hline
\end{tabular}




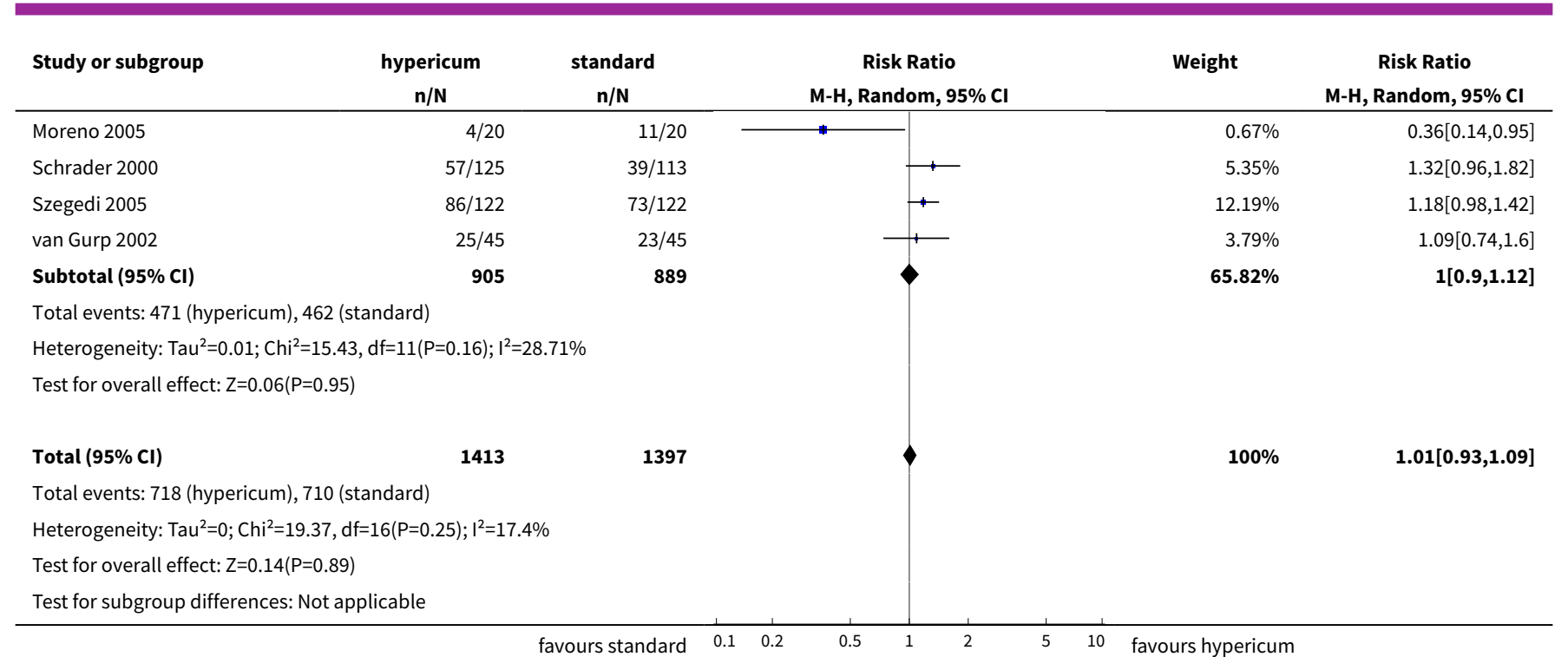

Analysis 4.2. Comparison 4 Hypericum mono-preparations vs. standard antidepressants. A. Dichotomous measures, Outcome 2 Responder (per protocol).

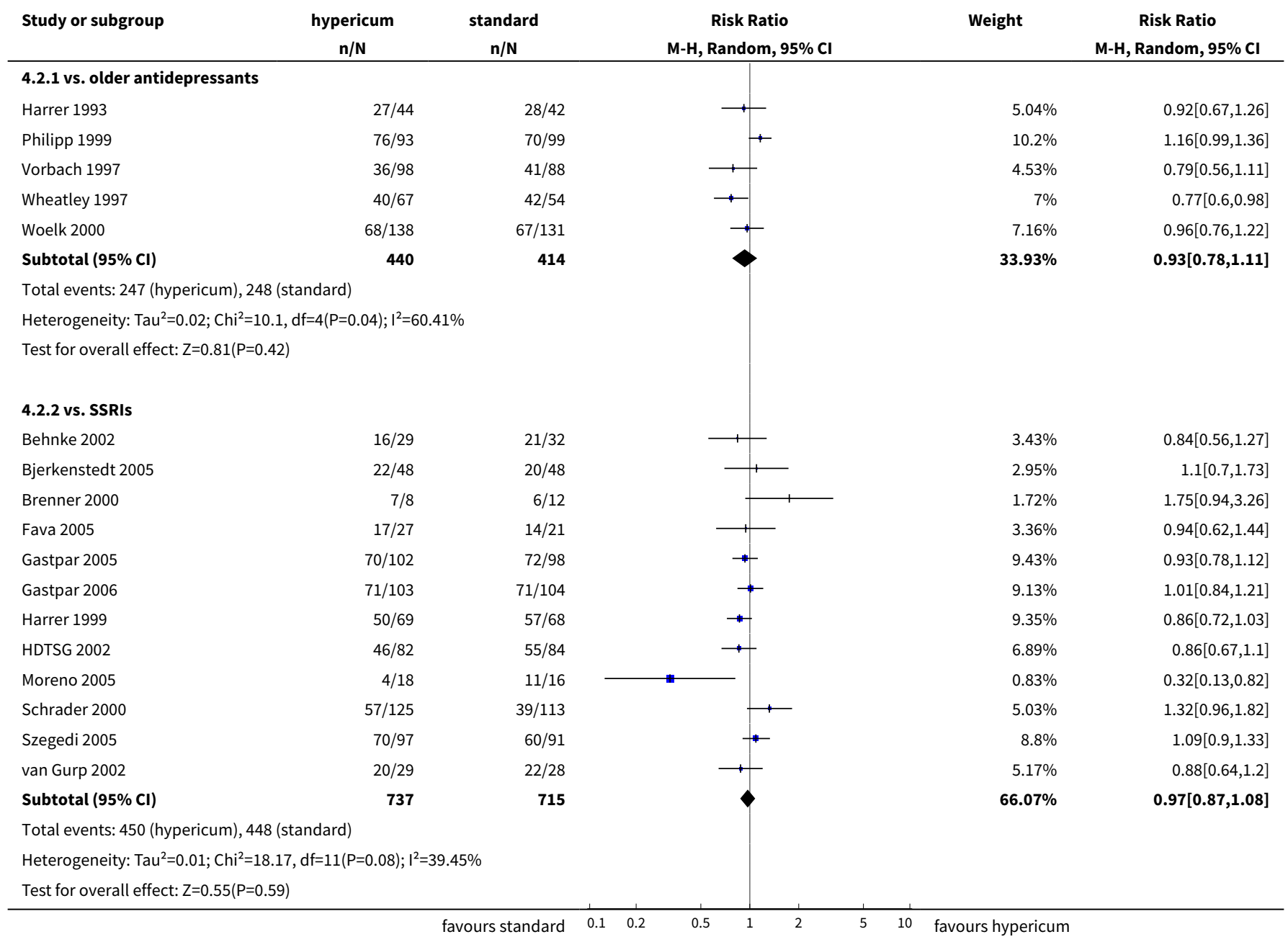




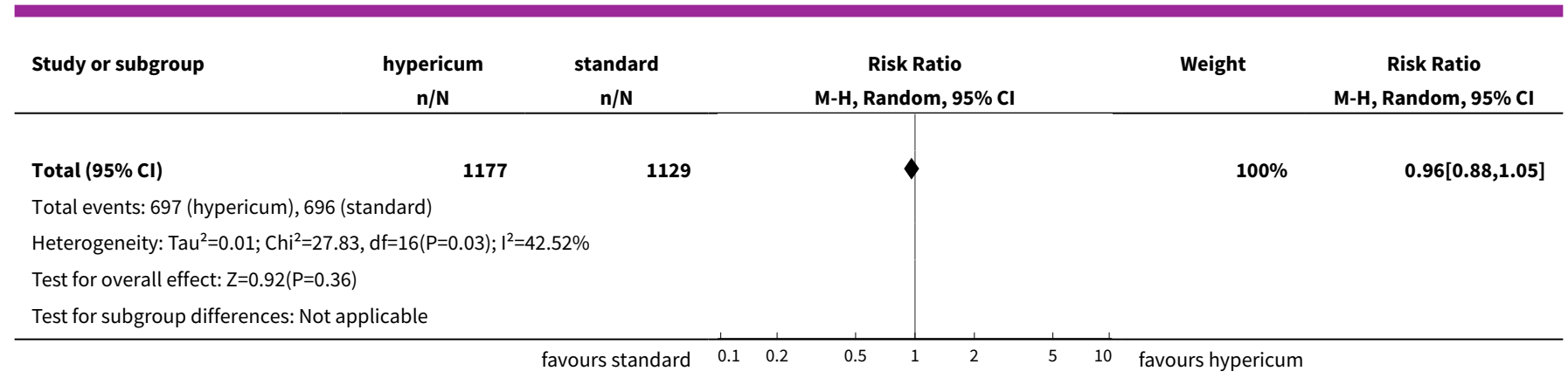

Analysis 4.3. Comparison 4 Hypericum mono-preparations vs. standard antidepressants. A. Dichotomous measures, Outcome 3 Responders according to CGI (Clinical Global Impression Index at least "much improved").

\begin{tabular}{|c|c|c|c|c|c|}
\hline Study or subgroup & $\begin{array}{l}\text { hypericum } \\
\mathrm{n} / \mathrm{N}\end{array}$ & $\begin{array}{c}\text { standard } \\
n / N\end{array}$ & $\begin{array}{c}\text { Risk Ratio } \\
\text { M-H, Random, } 95 \% \text { Cl }\end{array}$ & Weight & $\begin{array}{c}\text { Risk Ratio } \\
\text { M-H, Random, } 95 \% \text { Cl }\end{array}$ \\
\hline \multicolumn{6}{|c|}{ 4.3.1 vs. older antidepressants } \\
\hline Harrer 1993 & $22 / 51$ & $20 / 51$ & 1 & $2.54 \%$ & $1.1[0.69,1.75]$ \\
\hline Philipp 1999 & $77 / 106$ & $78 / 110$ & & $13.24 \%$ & $1.02[0.87,1.21]$ \\
\hline Vorbach 1997 & $60 / 107$ & $64 / 102$ & $\rightarrow$ & $8.81 \%$ & $0.89[0.71,1.12]$ \\
\hline Wheatley 1997 & $55 / 87$ & $53 / 78$ & $\rightarrow$ & $9.02 \%$ & $0.93[0.75,1.16]$ \\
\hline Subtotal $(95 \% \mathrm{Cl})$ & 351 & 341 & & $33.61 \%$ & $0.97[0.87,1.09]$ \\
\hline \multicolumn{6}{|c|}{ Total events: 214 (hypericum), 215 (standard) } \\
\hline \multicolumn{6}{|c|}{ Heterogeneity: $\operatorname{Tau}^{2}=0 ; \mathrm{Chi}^{2}=1.34, \mathrm{df}=3(\mathrm{P}=0.72) ; \mathrm{I}^{2}=0 \%$} \\
\hline \multicolumn{6}{|c|}{ Test for overall effect: $Z=0.52(P=0.6)$} \\
\hline \multicolumn{6}{|c|}{ 4.3.2 vs. newer antidepressants } \\
\hline Behnke 2002 & $21 / 35$ & $24 / 35$ & $\longrightarrow$ & $4.22 \%$ & $0.88[0.62,1.24]$ \\
\hline Gastpar 2005 & $70 / 123$ & $62 / 118$ & *- & $8.48 \%$ & $1.08[0.86,1.36]$ \\
\hline Gastpar 2006 & $85 / 131$ & $86 / 127$ & $\rightarrow$ & $12.59 \%$ & $0.96[0.81,1.14]$ \\
\hline Harrer 1999 & $49 / 77$ & $54 / 84$ & $\rightarrow$ & $8.38 \%$ & $0.99[0.78,1.25]$ \\
\hline HDTSG 2002 & $47 / 113$ & $61 / 109$ & $\rightarrow$ & $6.42 \%$ & $0.74[0.56,0.98]$ \\
\hline Schrader 2000 & $94 / 125$ & $71 / 113$ & + & $12.6 \%$ & $1.2[1.01,1.42]$ \\
\hline Szegedi 2005 & $83 / 122$ & $70 / 122$ & + & $10.78 \%$ & $1.19[0.98,1.44]$ \\
\hline Subtotal $(95 \% \mathrm{CI})$ & 780 & 762 & 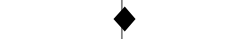 & $66.39 \%$ & $1.03[0.92,1.15]$ \\
\hline \multicolumn{6}{|c|}{ Total events: 474 (hypericum), 450 (standard) } \\
\hline \multicolumn{6}{|c|}{ Heterogeneity: $\operatorname{Tau}^{2}=0.01 ; \mathrm{Chi}^{2}=12.28, \mathrm{df}=7(\mathrm{P}=0.09) ; \mathrm{I}^{2}=43.01 \%$} \\
\hline \multicolumn{6}{|c|}{ Test for overall effect: $Z=0.45(P=0.66)$} \\
\hline Total $(95 \% \mathrm{Cl})$ & 1131 & 1103 & $>$ & $100 \%$ & $1.01[0.94,1.09]$ \\
\hline \multicolumn{6}{|c|}{ Total events: 688 (hypericum), 665 (standard) } \\
\hline \multicolumn{6}{|c|}{ Test for overall effect: $Z=0.25(P=0.8)$} \\
\hline Test for subgroup dif & icable & & & & \\
\hline
\end{tabular}

St John's wort for major depression (Review) 
Analysis 4.4. Comparison 4 Hypericum mono-preparations vs. standard antidepressants. A. Dichotomous measures, Outcome 4 Responder among studies from German-speaking studies and other studies.

\begin{tabular}{|c|c|c|c|c|c|}
\hline Study or subgroup & $\begin{array}{c}\text { hypericum } \\
\mathrm{n} / \mathrm{N}\end{array}$ & $\begin{array}{c}\text { Control } \\
n / N\end{array}$ & $\begin{array}{c}\text { Risk Ratio } \\
\text { M-H, Random, } 95 \% \mathrm{Cl} \\
\end{array}$ & Weight & $\begin{array}{c}\text { Risk Ratio } \\
\text { M-H, Random, } 95 \% \mathrm{Cl} \\
\end{array}$ \\
\hline \multicolumn{6}{|c|}{ 4.4.1 Studies from German-speaking countries } \\
\hline Gastpar 2005 & $70 / 102$ & $72 / 98$ & $\rightarrow$ & $12.57 \%$ & $0.93[0.78,1.12]$ \\
\hline Gastpar 2006 & $71 / 131$ & $71 / 127$ & $\rightarrow$ & $9.31 \%$ & $0.97[0.78,1.21]$ \\
\hline Harrer 1993 & $27 / 51$ & $28 / 51$ & 1 & $4.23 \%$ & $0.96[0.67,1.38]$ \\
\hline Harrer 1999 & $50 / 77$ & $57 / 84$ & - & $9.32 \%$ & $0.96[0.77,1.19]$ \\
\hline Philipp 1999 & $76 / 106$ & $70 / 110$ & + & $11.87 \%$ & $1.13[0.94,1.36]$ \\
\hline Schrader 2000 & $57 / 125$ & $39 / 113$ & 1 & $5.21 \%$ & $1.32[0.96,1.82]$ \\
\hline Szegedi 2005 & $86 / 122$ & $73 / 122$ & $\leftarrow$ & $11.86 \%$ & $1.18[0.98,1.42]$ \\
\hline Vorbach 1997 & $36 / 107$ & $41 / 102$ & $\longrightarrow$ & $4.29 \%$ & $0.84[0.59,1.2]$ \\
\hline Woelk 2000 & $68 / 157$ & $67 / 167$ & - & $7.36 \%$ & $1.08[0.83,1.4]$ \\
\hline Subtotal $(95 \% \mathrm{Cl})$ & 978 & 974 & $\bullet$ & $76.01 \%$ & $1.04[0.96,1.13]$ \\
\hline \multicolumn{6}{|c|}{ Total events: 541 (hypericum), 518 (Control) } \\
\hline \multicolumn{6}{|c|}{ Heterogeneity: $\mathrm{Tau}^{2}=0 ; \mathrm{Chi}^{2}=8.67, \mathrm{df}=8(\mathrm{P}=0.37) ; \mathrm{I}^{2}=7.74 \%$} \\
\hline \multicolumn{6}{|c|}{ Test for overall effect: $Z=0.95(P=0.34)$} \\
\hline \multicolumn{6}{|c|}{ 4.4.2 Studies from other countries } \\
\hline Behnke 2002 & $16 / 35$ & $21 / 35$ & - & $2.8 \%$ & $0.76[0.49,1.2]$ \\
\hline Bjerkenstedt 2005 & $22 / 54$ & $20 / 54$ & & $2.56 \%$ & $1.1[0.68,1.77]$ \\
\hline Brenner 2000 & $7 / 15$ & $6 / 15$ & 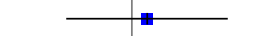 & $0.89 \%$ & $1.17[0.51,2.66]$ \\
\hline Fava 2005 & $17 / 45$ & $14 / 47$ & & $1.77 \%$ & $1.27[0.71,2.26]$ \\
\hline HDTSG 2002 & $46 / 113$ & $55 / 109$ & $\longrightarrow$ & $6.08 \%$ & $0.81[0.6,1.08]$ \\
\hline Moreno 2005 & $4 / 20$ & $11 / 20$ & 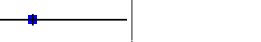 & $0.66 \%$ & $0.36[0.14,0.95]$ \\
\hline van Gurp 2002 & $25 / 45$ & $23 / 45$ & $1-$ & $3.7 \%$ & $1.09[0.74,1.6]$ \\
\hline Wheatley 1997 & $40 / 87$ & $42 / 78$ & $\longrightarrow$ & $5.54 \%$ & $0.85[0.63,1.16]$ \\
\hline Subtotal $(95 \% \mathrm{Cl})$ & 414 & 403 & 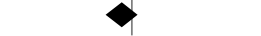 & $23.99 \%$ & $0.9[0.76,1.06]$ \\
\hline \multicolumn{6}{|c|}{ Total events: 177 (hypericum), 192 (Control) } \\
\hline \multicolumn{6}{|c|}{ Heterogeneity: $\mathrm{Tau}^{2}=0.01 ; \mathrm{Chi}^{2}=7.93, \mathrm{df}=7(\mathrm{P}=0.34) ; 1^{2}=11.78 \%$} \\
\hline \multicolumn{6}{|c|}{ Test for overall effect: $Z=1.22(P=0.22)$} \\
\hline Total $(95 \% \mathrm{Cl})$ & 1392 & 1377 & 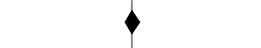 & $100 \%$ & $1[0.93,1.09]$ \\
\hline \multicolumn{6}{|c|}{ Total events: 718 (hypericum), 710 (Control) } \\
\hline \multicolumn{6}{|c|}{ Heterogeneity: Tau $^{2}=0 ; \mathrm{Chi}^{2}=19.53, \mathrm{df}=16(\mathrm{P}=0.24) ; I^{2}=18.08 \%$} \\
\hline \multicolumn{6}{|c|}{ Test for overall effect: $Z=0.1(P=0.92)$} \\
\hline Test for subgroup dif & licable & & & & \\
\hline
\end{tabular}

Analysis 4.5. Comparison 4 Hypericum mono-preparations vs. standard antidepressants. A. Dichotomous measures, Outcome 5 Remission (HAMD score $<8$ ).

\begin{tabular}{ccccc} 
Study or subgroup & Treatment & Control & Risk Ratio & Wisk Ratio \\
& $\mathrm{n} / \mathrm{N}$ & $\mathrm{n} / \mathrm{N}$ & $\mathrm{M}-\mathrm{H}, \mathrm{Random}, 95 \% \mathrm{Cl}$ & $\mathrm{M}-\mathrm{H}, \mathrm{Random}, 95 \% \mathrm{Cl}$ \\
\hline
\end{tabular}

4.5.1 vs. older antidepressants
Subtotal $(95 \% \mathrm{Cl})$
Total events: 0 (Treatment), 0 (Control)
Heterogeneity: Not applicable
Test for overall effect: Not applicable




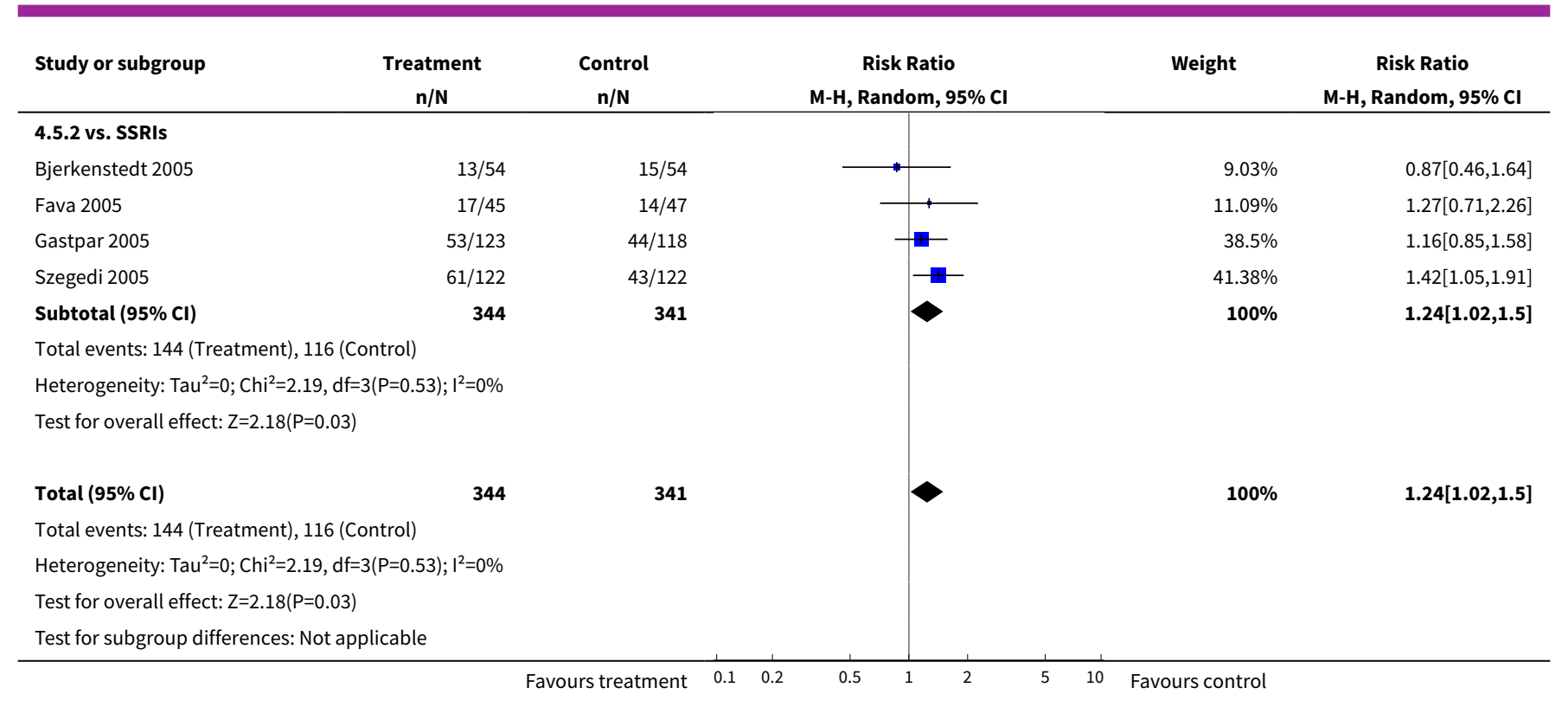

\section{Comparison 5. Hypericum mono-preparations vs. standard antidepressants. B. Continuous measures}

\begin{tabular}{|c|c|c|c|c|}
\hline Outcome or subgroup title & $\begin{array}{l}\text { No. of } \\
\text { studies }\end{array}$ & $\begin{array}{l}\text { No. of } \\
\text { partici- } \\
\text { pants }\end{array}$ & Statistical method & Effect size \\
\hline $\begin{array}{l}1 \text { Mean HAMD (Hamilton Rating } \\
\text { Scale for Depression) after ther- } \\
\text { apy }\end{array}$ & 12 & 1889 & Mean Difference (IV, Random, 95\% CI) & $-0.39[-1.23,0.45]$ \\
\hline 1.1 vs. older antidepressants & 3 & 477 & Mean Difference (IV, Random, 95\% Cl) & $-0.06[-1.82,1.71]$ \\
\hline 1.2 vs. SSRIs & 9 & 1412 & Mean Difference (IV, Random, 95\% CI) & $-0.52[-1.55,0.51]$ \\
\hline $\begin{array}{l}2 \text { Mean HAMD (Hamilton Rating } \\
\text { Scale for Depression) scores af- } \\
\text { ter } 2 \text { or } 3 \text { weeks of treatment }\end{array}$ & 9 & 1529 & Mean Difference (IV, Random, 95\% CI) & $-0.12[-1.02,0.78]$ \\
\hline 2.1 vs. older antidepressants & 3 & 477 & Mean Difference (IV, Random, 95\% CI) & $-0.05[-1.31,1.20]$ \\
\hline 2.2 vs. SSRIs & 6 & 1052 & Mean Difference (IV, Random, 95\% CI) & $-0.25[-1.50,1.00]$ \\
\hline $\begin{array}{l}3 \text { Mean HAMD (Hamilton Rating } \\
\text { Scale for Depression) scores af- } \\
\text { ter } 4 \text { weeks of treatment }\end{array}$ & 9 & 1367 & Mean Difference (IV, Random, 95\% CI) & $-0.34[-1.48,0.80]$ \\
\hline $3.1 \mathrm{vs.} \mathrm{older} \mathrm{antidepressants}$ & 3 & 477 & Mean Difference (IV, Random, 95\% CI) & $0.02[-1.11,1.15]$ \\
\hline 3.2 vs. SSRIs & 6 & 890 & Mean Difference (IV, Random, 95\% CI) & $-0.69[-2.44,1.06]$ \\
\hline $\begin{array}{l}4 \text { Mean HAMD (Hamilton Rating } \\
\text { Scale for Depression) scores af- } \\
\text { ter } 6 \text { to } 8 \text { weeks of treatment }\end{array}$ & 10 & 1659 & Mean Difference (IV, Random, 95\% CI) & $-0.34[-1.24,0.57]$ \\
\hline 4.1 vs. older antidepressants & 2 & 391 & Mean Difference (IV, Random, 95\% CI) & $-0.21[-2.56,2.14]$ \\
\hline
\end{tabular}




\begin{tabular}{|c|c|c|c|c|}
\hline Outcome or subgroup title & $\begin{array}{l}\text { No. of } \\
\text { studies }\end{array}$ & $\begin{array}{l}\text { No. of } \\
\text { partici- } \\
\text { pants }\end{array}$ & Statistical method & Effect size \\
\hline 4.2 vs. SSRIs & 8 & 1268 & Mean Difference (IV, Random, 95\% CI) & $-0.38[-1.46,0.69]$ \\
\hline $\begin{array}{l}5 \text { Difference HAMD (Hamilton } \\
\text { Rating Scale for Depression) } \\
\text { baseline - end of treatment }\end{array}$ & 10 & 1652 & Mean Difference (IV, Random, 95\% CI) & $-0.35[-1.23,0.52]$ \\
\hline 5.1 vs. older antidepressants & 1 & 210 & Mean Difference (IV, Random, 95\% CI) & $-1.20[-3.29,0.89]$ \\
\hline 5.2 vs. SSRIs & 9 & 1442 & Mean Difference (IV, Random, 95\% CI) & $-0.25[-1.21,0.71]$ \\
\hline 6 MADRS after treatment & 1 & 108 & Mean Difference (IV, Random, 95\% CI) & $-0.90[-4.73,2.93]$ \\
\hline 6.1 vs. older antidepressants & 0 & 0 & Mean Difference (IV, Random, 95\% CI) & $0.0[0.0,0.0]$ \\
\hline 6.2 vs. SSRIs & 1 & 108 & Mean Difference (IV, Random, 95\% CI) & $-0.90[-4.73,2.93]$ \\
\hline $\begin{array}{l}7 \text { Difference MADRS baseline - } \\
\text { end of treatment }\end{array}$ & 2 & 352 & Mean Difference (IV, Random, 95\% CI) & $-2.90[-5.10,-0.70]$ \\
\hline 7.1 vs. older antidepressants & 0 & 0 & Mean Difference (IV, Random, 95\% CI) & $0.0[0.0,0.0]$ \\
\hline 7.2 vs. SSRIs & 2 & 352 & Mean Difference (IV, Random, 95\% CI) & $-2.90[-5.10,-0.70]$ \\
\hline $\begin{array}{l}8 \text { Mean HAMD after treatment in } \\
\text { studies from German-speaking } \\
\text { countries and other studies }\end{array}$ & 15 & 2423 & Mean Difference (IV, Random, 95\% CI) & $-0.39[-1.23,0.45]$ \\
\hline $\begin{array}{l}8.1 \text { Studies from German-speak- } \\
\text { ing countries }\end{array}$ & 9 & 1888 & Mean Difference (IV, Random, 95\% CI) & $-0.43[-1.28,0.41]$ \\
\hline 8.2 Studies from other countries & 6 & 535 & Mean Difference (IV, Random, 95\% CI) & $-0.44[-2.67,1.79]$ \\
\hline $\begin{array}{l}9 \text { Mean D-S (Depression Scale } \\
\text { von Zerssen) scores after thera- } \\
\text { py }\end{array}$ & 4 & 360 & Mean Difference (IV, Random, 95\% CI) & $2.66[0.83,4.50]$ \\
\hline 9.1 vs. older antidepressants & 2 & 272 & Mean Difference (IV, Random, 95\% CI) & $2.81[0.77,4.85]$ \\
\hline 9.2 vs. SSRIs & 2 & 88 & Mean Difference (IV, Random, 95\% CI) & $2.04[-2.13,6.21]$ \\
\hline 10 Various self-rating scales & 10 & 1570 & Std. Mean Difference (IV, Random, 95\% CI) & $0.01[-0.13,0.15]$ \\
\hline $\begin{array}{l}10.1 \text { von Zerssen Depression } \\
\text { Scale (D-S) after treatment }\end{array}$ & 4 & 360 & Std. Mean Difference (IV, Random, 95\% CI) & $0.28[0.07,0.49]$ \\
\hline 10.2 Beck Depression Inventory & 1 & 83 & Std. Mean Difference (IV, Random, 95\% CI) & $-0.01[-0.44,0.42]$ \\
\hline $\begin{array}{l}10.3 \text { Beck Depression Inventory } \\
\text { difference baseline - after treat- } \\
\text { ment }\end{array}$ & 2 & 466 & Std. Mean Difference (IV, Random, 95\% CI) & $-0.12[-0.53,0.29]$ \\
\hline $\begin{array}{l}\text { 10.4 Zung Self Rating Depres- } \\
\text { sion Scale (SDS) difference } \\
\text { baseline - after treatment }\end{array}$ & 1 & 205 & Std. Mean Difference (IV, Random, 95\% CI) & $-0.11[-0.38,0.17]$ \\
\hline
\end{tabular}




\begin{tabular}{llllll}
\hline Outcome or subgroup title & $\begin{array}{l}\text { No. of } \\
\text { studies }\end{array}$ & $\begin{array}{l}\text { No. of } \\
\text { partici- } \\
\text { pants }\end{array}$ & Statistical method & Effect size \\
\hline $\begin{array}{l}10.5 \text { von Zerssen Adjective } \\
\text { Mood Scale }\end{array}$ & 2 & 456 & Std. Mean Difference (IV, Random, 95\% Cl) & $-0.06[-0.24,0.13]$ \\
\hline $\begin{array}{l}11 \text { Various self-rating scales in } \\
\text { studies from German-speaking } \\
\text { countries and other countries }\end{array}$ & 10 & 1570 & Std. Mean Difference (IV, Random, 95\% Cl) & $0.01[-0.13,0.15]$ \\
\hline $\begin{array}{l}11.1 \text { Studies from Ger- } \\
\text { man-speaking countries }\end{array}$ & 6 & 1177 & Std. Mean Difference (IV, Random, 95\% Cl) & $-0.02[-0.21,0.18]$ \\
\hline $\begin{array}{l}11.2 \text { Studies from other coun- } \\
\text { tries }\end{array}$ & 4 & 393 & Std. Mean Difference (IV, Random, 95\% Cl) & $0.10[-0.10,0.29]$ \\
\hline
\end{tabular}

Analysis 5.1. Comparison 5 Hypericum mono-preparations vs. standard antidepressants. B. Continuous measures, Outcome 1 Mean HAMD (Hamilton Rating Scale for Depression) after therapy.

\begin{tabular}{|c|c|c|c|c|c|c|c|}
\hline \multirow[t]{2}{*}{ Study or subgroup } & \multicolumn{2}{|c|}{ hypericum } & \multicolumn{2}{|c|}{ standard } & \multirow{2}{*}{$\begin{array}{l}\text { Mean Difference } \\
\text { Random, } 95 \% \mathrm{Cl}\end{array}$} & \multirow[t]{2}{*}{ Weight } & \multirow{2}{*}{$\begin{array}{l}\text { Mean Difference } \\
\text { Random, } 95 \% \mathrm{Cl}\end{array}$} \\
\hline & $\mathbf{N}$ & Mean(SD) & $\mathbf{N}$ & Mean(SD) & & & \\
\hline \multicolumn{8}{|c|}{ 5.1.1 vs. older antidepressants } \\
\hline Harrer 1993 & 44 & $11.2(9.9)$ & 42 & $10.5(7.5)$ & & $4.08 \%$ & $0.7[-3,4.4]$ \\
\hline Philipp 1999 & 100 & $9.2(6.2)$ & 105 & $10.6(6.1)$ & 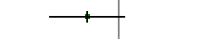 & $10.96 \%$ & $-1.4[-3.08,0.28]$ \\
\hline Vorbach 1997 & 98 & $14.4(6.1)$ & 88 & $13.4(5.9)$ & & $10.73 \%$ & $1[-0.73,2.73]$ \\
\hline Subtotal $* \star \star$ & 242 & & 235 & & & $25.76 \%$ & $-0.06[-1.82,1.71]$ \\
\hline \multicolumn{8}{|c|}{ Heterogeneity: $\mathrm{Tau}^{2}=1.19 ; \mathrm{Chi}^{2}=4.02, \mathrm{df}=2(\mathrm{P}=0.13) ; \mathrm{I}^{2}=50.29 \%$} \\
\hline \multicolumn{8}{|c|}{ Test for overall effect: $\mathrm{Z}=0.06(\mathrm{P}=0.95)$} \\
\hline \multicolumn{8}{|l|}{ 5.1.2 vs. SSRIs } \\
\hline Bjerkenstedt 2005 & 54 & $15(8.4)$ & 54 & $14.9(8.4)$ & & $5.17 \%$ & $0.1[-3.07,3.27]$ \\
\hline Brenner 2000 & 13 & $12.7(6.7)$ & 15 & $12.5(5.6)$ & & $2.83 \%$ & $0.2[-4.41,4.81]$ \\
\hline Fava 2005 & 45 & $10.2(6.6)$ & 47 & $13.3(7.3)$ & 1 & $6.04 \%$ & $-3.1[-5.94,-0.26]$ \\
\hline Gastpar 2006 & 131 & $10.3(6.4)$ & 127 & $10.3(6.4)$ & - & $11.68 \%$ & $0[-1.56,1.56]$ \\
\hline HDTSG 2002 & 82 & $12.9(7.1)$ & 77 & $10.7(5.9)$ & 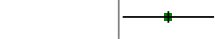 & $9.16 \%$ & $2.2[0.18,4.22]$ \\
\hline Schrader 2000 & 125 & $10.9(4.3)$ & 113 & $11.5(4)$ & $\rightarrow$ & $14.96 \%$ & $-0.55[-1.61,0.51]$ \\
\hline Szegedi 2005 & 122 & $11.2(9)$ & 122 & $14.2(8.9)$ & + & $8.16 \%$ & $-3[-5.25,-0.75]$ \\
\hline van Gurp 2002 & 44 & $9.4(8.3)$ & 43 & $11.6(8.4)$ & - & $4.44 \%$ & $-2.13[-5.63,1.37]$ \\
\hline Subtotal $* \star \star$ & 717 & & 695 & & & $74.24 \%$ & $-0.52[-1.55,0.51]$ \\
\hline \multicolumn{8}{|c|}{ Heterogeneity: $\mathrm{Tau}^{2}=1.16 ; \mathrm{Chi}^{2}=16.96, \mathrm{df}=8(\mathrm{P}=0.03) ; \mathrm{I}^{2}=52.82 \%$} \\
\hline \multicolumn{8}{|c|}{ Test for overall effect: $Z=0.99(P=0.32)$} \\
\hline Total $\star \star \star ~$ & 959 & & 930 & & & $100 \%$ & $-0.39[-1.23,0.45]$ \\
\hline \multicolumn{8}{|c|}{ Heterogeneity: $\mathrm{Tau}^{2}=0.94 ; \mathrm{Chi}^{2}=21.13, \mathrm{df}=11(\mathrm{P}=0.03) ; \mathrm{I}^{2}=47.95 \%$} \\
\hline \multicolumn{8}{|c|}{ Test for overall effect: $Z=0.91(P=0.36)$} \\
\hline \multicolumn{8}{|c|}{ Test for subgroup differences: $\mathrm{Chi}^{2}=0.15, \mathrm{df}=1(\mathrm{P}=0.7), \mathrm{I}^{2}=0 \%$} \\
\hline
\end{tabular}


Analysis 5.2. Comparison 5 Hypericum mono-preparations vs. standard antidepressants. B. Continuous measures, Outcome 2 Mean HAMD (Hamilton Rating Scale for Depression) scores after 2 or $\mathbf{3}$ weeks of treatment.

\begin{tabular}{|c|c|c|c|c|c|c|c|}
\hline \multirow[t]{2}{*}{ Study or subgroup } & \multicolumn{2}{|c|}{ hypericum } & \multicolumn{2}{|c|}{ standard } & \multirow{2}{*}{$\begin{array}{l}\text { Mean Difference } \\
\text { Random, } 95 \% \mathrm{Cl}\end{array}$} & \multirow[t]{2}{*}{ Weight } & \multirow{2}{*}{$\begin{array}{l}\text { Mean Difference } \\
\text { Random, } 95 \% \mathrm{Cl}\end{array}$} \\
\hline & $\mathbf{N}$ & Mean(SD) & $\mathbf{N}$ & Mean(SD) & & & \\
\hline \multicolumn{8}{|c|}{ 5.2.1 vs. older antidepressants } \\
\hline Harrer 1993 & 44 & $15.1(7.9)$ & 42 & $12.9(6.8)$ & + & $6.02 \%$ & $2.2[-0.91,5.31]$ \\
\hline Philipp 1999 & 100 & $16.5(5.8)$ & 105 & $16.9(5.9)$ & - & $12.73 \%$ & $-0.4[-2,1.2]$ \\
\hline Vorbach 1997 & 98 & $19.6(5.9)$ & 88 & $20.1(6.2)$ & +1 & $11.84 \%$ & $-0.5[-2.24,1.24]$ \\
\hline Subtotal $\star \star \star$ & 242 & & 235 & & & $30.58 \%$ & $-0.05[-1.31,1.2]$ \\
\hline \multicolumn{8}{|c|}{ Test for overall effect: $Z=0.09(P=0.93)$} \\
\hline \multicolumn{8}{|l|}{ 5.2.2 vs. SSRIs } \\
\hline Fava 2005 & 42 & $12.3(5.9)$ & 36 & $14.7(4.1)$ & ? & $9.23 \%$ & $-2.4[-4.63,-0.17]$ \\
\hline Gastpar 2005 & 99 & $16(5.3)$ & 96 & $15.6(5.8)$ & + & $12.99 \%$ & $0.4[-1.16,1.96]$ \\
\hline Gastpar 2006 & 131 & $13.5(5.7)$ & 127 & $13.7(5.8)$ & - & $14.04 \%$ & $-0.2[-1.6,1.2]$ \\
\hline Szegedi 2005 & 122 & $20.4(6.8)$ & 122 & $20.5(6.7)$ & 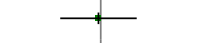 & $12.15 \%$ & $-0.1[-1.79,1.59]$ \\
\hline van Gurp 2002 & 44 & $14.4(5.9)$ & 43 & $16.7(5.7)$ & & $8.33 \%$ & $-2.38[-4.82,0.06]$ \\
\hline Subtotal $* \star \star$ & 540 & & 512 & & & $69.42 \%$ & $-0.25[-1.5,1]$ \\
\hline \multicolumn{8}{|c|}{ Heterogeneity: $\mathrm{Tau}^{2}=1.58 ; \mathrm{Chi}^{2}=14.99, \mathrm{df}=5(\mathrm{P}=0.01) ; \mathrm{I}^{2}=66.64 \%$} \\
\hline \multicolumn{8}{|c|}{ Test for overall effect: $Z=0.4(P=0.69)$} \\
\hline 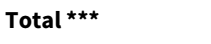 & 782 & & 747 & & & $100 \%$ & $-0.12[-1.02,0.78]$ \\
\hline \multicolumn{8}{|c|}{ Heterogeneity: $\mathrm{Tau}^{2}=0.99 ; \mathrm{Chi}^{2}=17.44, \mathrm{df}=8(\mathrm{P}=0.03) ; \mathrm{I}^{2}=54.13 \%$} \\
\hline \multicolumn{8}{|c|}{ Test for overall effect: $Z=0.26(P=0.79)$} \\
\hline Test for subgroup dif & $02, \mathrm{df}=$ & $P=0.89), I^{2}=09$ & & & & & \\
\hline
\end{tabular}

Analysis 5.3. Comparison 5 Hypericum mono-preparations vs. standard antidepressants. B. Continuous measures, Outcome 3 Mean HAMD (Hamilton Rating Scale for Depression) scores after 4 weeks of treatment.

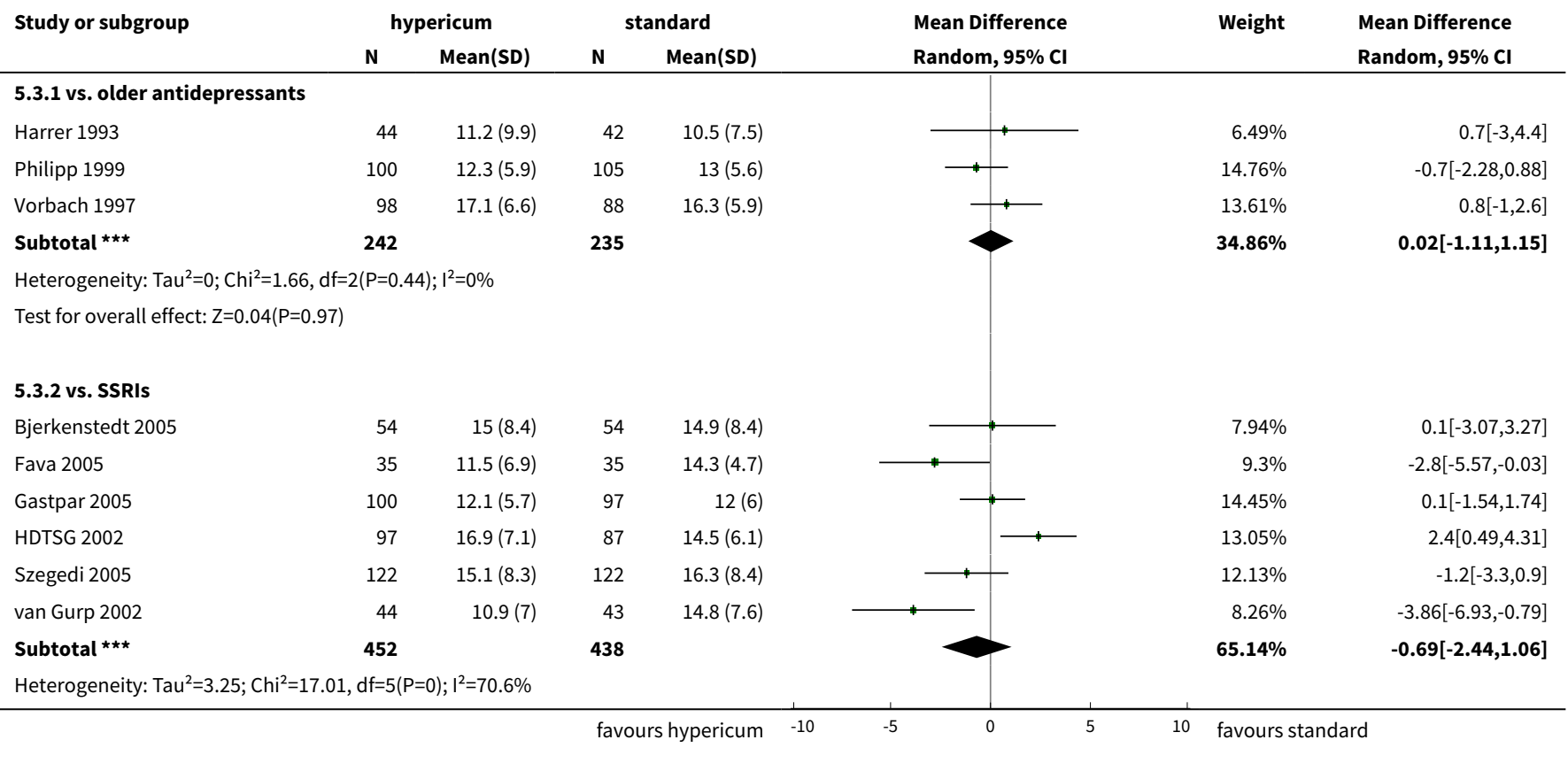

St John's wort for major depression (Review) 


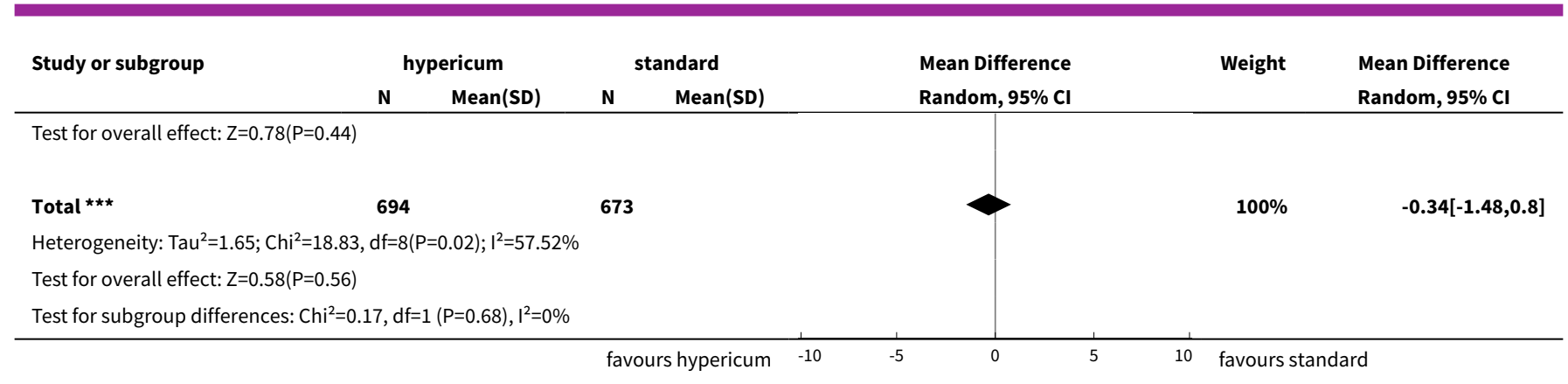

Analysis 5.4. Comparison 5 Hypericum mono-preparations vs. standard antidepressants. B. Continuous measures, Outcome 4 Mean HAMD (Hamilton Rating Scale for Depression) scores after 6 to 8 weeks of treatment.

\begin{tabular}{|c|c|c|c|c|c|c|c|}
\hline \multirow[t]{2}{*}{ Study or subgroup } & \multicolumn{2}{|c|}{ hypericum } & \multicolumn{2}{|c|}{ standard } & \multirow{2}{*}{$\begin{array}{l}\text { Mean Difference } \\
\text { Random, } 95 \% \mathrm{CI}\end{array}$} & \multirow[t]{2}{*}{ Weight } & \multirow{2}{*}{$\begin{array}{l}\text { Mean Difference } \\
\text { Random, } 95 \% \mathrm{Cl}\end{array}$} \\
\hline & $\mathbf{N}$ & Mean(SD) & $\mathbf{N}$ & Mean(SD) & & & \\
\hline \multicolumn{8}{|c|}{ 5.4.1 vs. older antidepressants } \\
\hline Philipp 1999 & 100 & $9.2(6.2)$ & 105 & $10.6(6.1)$ & $r$ & $12.07 \%$ & $-1.4[-3.08,0.28]$ \\
\hline Vorbach 1997 & 98 & $14.4(6.1)$ & 88 & $13.4(5.9)$ & & $11.82 \%$ & $1[-0.73,2.73]$ \\
\hline Subtotal $\star \star \star$ & 198 & & 193 & & & $23.89 \%$ & $-0.21[-2.56,2.14]$ \\
\hline \multicolumn{8}{|c|}{ Heterogeneity: $\mathrm{Tau}^{2}=2.12 ; \mathrm{Chi}^{2}=3.8, \mathrm{df}=1(\mathrm{P}=0.05) ; \mathrm{I}^{2}=73.71 \%$} \\
\hline \multicolumn{8}{|l|}{ 5.4.2 vs. SSRIs } \\
\hline Brenner 2000 & 13 & $12.7(6.7)$ & 15 & $12.5(5.6)$ & & $3.23 \%$ & $0.2[-4.41,4.81]$ \\
\hline Fava 2005 & 32 & $10.3(5.9)$ & 28 & $11.2(5.8)$ & & $6.41 \%$ & $-0.9[-3.87,2.07]$ \\
\hline Gastpar 2005 & 100 & $9.8(5.2)$ & 94 & $9.3(5.9)$ & + & $12.78 \%$ & $0.5[-1.07,2.07]$ \\
\hline Gastpar 2006 & 131 & $10.3(6.4)$ & 127 & $10.3(6.4)$ & - & $12.82 \%$ & $0[-1.56,1.56]$ \\
\hline Schrader 2000 & 125 & $10.9(4.3)$ & 113 & $11.5(4)$ & $\rightarrow$ & $16.2 \%$ & $-0.55[-1.61,0.51]$ \\
\hline Szegedi 2005 & 122 & $11.2(9)$ & 122 & $14.2(8.9)$ & 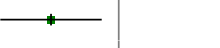 & $9.09 \%$ & $-3[-5.25,-0.75]$ \\
\hline van Gurp 2002 & 44 & $10.2(8.2)$ & 43 & $13.2(7.8)$ & & $5.4 \%$ & $-2.96[-6.3,0.38]$ \\
\hline 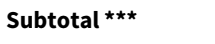 & 649 & & 619 & & & $76.11 \%$ & $-0.38[-1.46,0.69]$ \\
\hline \multicolumn{8}{|c|}{ Heterogeneity: $\operatorname{Tau}^{2}=1.16 ; \mathrm{Chi}^{2}=15.4, \mathrm{df}=7(\mathrm{P}=0.03) ; \mathrm{I}^{2}=54.54 \%$} \\
\hline \multicolumn{8}{|c|}{ Test for overall effect: $Z=0.7(P=0.48)$} \\
\hline Total $\star \star \star ~$ & 847 & & 812 & & & $100 \%$ & $-0.34[-1.24,0.57]$ \\
\hline \multicolumn{8}{|c|}{ Heterogeneity: $\operatorname{Tau}^{2}=1.02 ; \mathrm{Chi}^{2}=19.21, \mathrm{df}=9(\mathrm{P}=0.02) ; \mathrm{I}^{2}=53.15 \%$} \\
\hline \multicolumn{8}{|c|}{ Test for overall effect: $\mathrm{Z}=0.73(\mathrm{P}=0.47)$} \\
\hline \multicolumn{8}{|c|}{ Test for subgroup differences: $\mathrm{Chi}^{2}=0.01, \mathrm{df}=1(\mathrm{P}=0.93), \mathrm{I}^{2}=0 \%$} \\
\hline & & & fas & , & 0 & favours & \\
\hline
\end{tabular}

Analysis 5.5. Comparison 5 Hypericum mono-preparations vs. standard antidepressants. B. Continuous measures, Outcome 5 Difference HAMD (Hamilton Rating Scale for Depression) baseline - end of treatment.

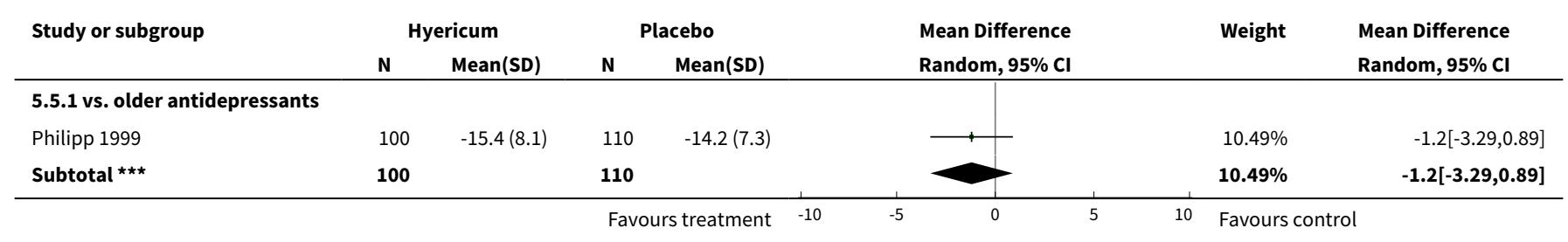




\begin{tabular}{|c|c|c|c|c|c|c|c|}
\hline \multirow[t]{2}{*}{ Study or subgroup } & \multicolumn{2}{|c|}{ Hyericum } & \multicolumn{2}{|c|}{ Placebo } & \multirow{2}{*}{$\begin{array}{l}\text { Mean Difference } \\
\text { Random, } 95 \% \mathrm{Cl}\end{array}$} & \multirow[t]{2}{*}{ Weight } & \multirow{2}{*}{$\begin{array}{l}\text { Mean Difference } \\
\text { Random, 95\% Cl }\end{array}$} \\
\hline & $\mathbf{N}$ & Mean(SD) & $\mathbf{N}$ & Mean(SD) & & & \\
\hline \multicolumn{8}{|c|}{ Heterogeneity: Not applicable } \\
\hline \multicolumn{8}{|c|}{ Test for overall effect: $Z=1.12(P=0.26)$} \\
\hline \multicolumn{8}{|l|}{ 5.5.2 vs. SSRIs } \\
\hline Behnke 2002 & 27 & $-10(5.8)$ & 32 & $-12(6.8)$ & & $5.78 \%$ & $2[-1.22,5.22]$ \\
\hline Bjerkenstedt 2005 & 54 & $-9.9(8.1)$ & 54 & $-8.9(8)$ & - & $6.31 \%$ & $-1[-4.04,2.04]$ \\
\hline Brenner 2000 & 13 & $-8.4(6.5)$ & 15 & $-9.1(5.2)$ & & $3.43 \%$ & $0.7[-3.71,5.11]$ \\
\hline Gastpar 2005 & 101 & $-13.7(5.4)$ & 97 & $-14(5.5)$ & + & $14.64 \%$ & $0.3[-1.22,1.82]$ \\
\hline Gastpar 2006 & 131 & $-11.6(6.3)$ & 127 & $-11.4(6.5)$ & $\longrightarrow$ & $14.27 \%$ & $-0.2[-1.76,1.36]$ \\
\hline HDTSG 2002 & 113 & $-8.7(7.2)$ & 109 & $-10.5(7.5)$ & $\longrightarrow$ & $11.44 \%$ & $1.85[-0.09,3.79]$ \\
\hline Schrader 2000 & 125 & $-8.1(5)$ & 113 & $-7.2(4.5)$ & $\rightarrow$ & $17.47 \%$ & $-0.86[-2.07,0.35]$ \\
\hline Szegedi 2005 & 122 & $-14.4(8.8)$ & 122 & $-11.4(8.6)$ & ? & $9.96 \%$ & $-3[-5.18,-0.82]$ \\
\hline van Gurp 2002 & 44 & $-9.5(7.1)$ & 43 & $-8.2(7.5)$ & +1 & $6.21 \%$ & $-1.3[-4.37,1.77]$ \\
\hline Subtotal $* \star \star$ & 730 & & 712 & & & $89.51 \%$ & $-0.25[-1.21,0.71]$ \\
\hline \multicolumn{8}{|c|}{ Heterogeneity: $\mathrm{Tau}^{2}=0.91 ; \mathrm{Chi}^{2}=14.8, \mathrm{df}=8(\mathrm{P}=0.06) ; \mathrm{I}^{2}=45.95 \%$} \\
\hline \multicolumn{8}{|c|}{ Test for overall effect: $Z=0.51(P=0.61)$} \\
\hline 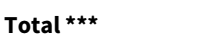 & 830 & & 822 & & & $100 \%$ & $-0.35[-1.23,0.52]$ \\
\hline \multicolumn{8}{|c|}{ Heterogeneity: $\mathrm{Tau}^{2}=0.76 ; \mathrm{Chi}^{2}=15.46, \mathrm{df}=9(\mathrm{P}=0.08) ; \mathrm{I}^{2}=41.77 \%$} \\
\hline \multicolumn{8}{|c|}{ Test for overall effect: $Z=0.79(P=0.43)$} \\
\hline Test for subgroup dif & $66, \mathrm{df}=$ & $P=0.42), I^{2}=0$ & & & & & \\
\hline
\end{tabular}

Analysis 5.6. Comparison 5 Hypericum mono-preparations vs. standard antidepressants. B. Continuous measures, Outcome 6 MADRS after treatment.

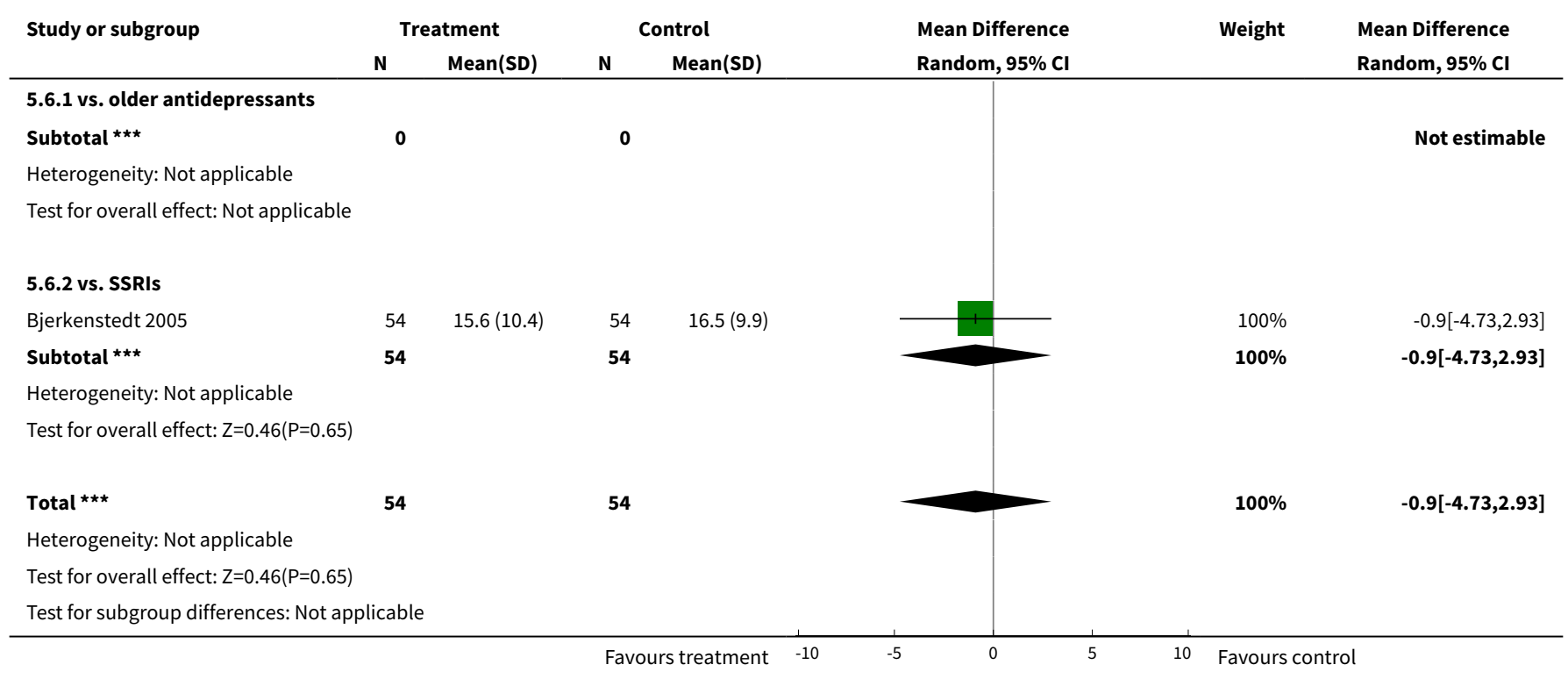

St John's wort for major depression (Review) 
Analysis 5.7. Comparison 5 Hypericum mono-preparations vs. standard antidepressants. B. Continuous measures, Outcome 7 Difference MADRS baseline - end of treatment.

\begin{tabular}{|c|c|c|c|c|c|c|c|}
\hline \multirow[t]{2}{*}{ Study or subgroup } & \multicolumn{2}{|c|}{ Treatment } & \multicolumn{2}{|c|}{ Control } & \multirow{2}{*}{$\begin{array}{l}\text { Mean Difference } \\
\text { Random, } 95 \% \mathrm{Cl}\end{array}$} & \multirow[t]{2}{*}{ Weight } & \multirow{2}{*}{$\begin{array}{l}\text { Mean Difference } \\
\text { Random, } 95 \% \mathrm{Cl}\end{array}$} \\
\hline & $\mathbf{N}$ & $\operatorname{Mean}(S D)$ & $\mathbf{N}$ & $\operatorname{Mean}(S D)$ & & & \\
\hline \multicolumn{8}{|c|}{ 5.7.1 vs. older antidepressants } \\
\hline 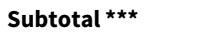 & \multicolumn{2}{|l|}{0} & \multicolumn{2}{|l|}{0} & & & Not estimable \\
\hline \multicolumn{8}{|c|}{ Heterogeneity: Not applicable } \\
\hline \multicolumn{8}{|c|}{ Test for overall effect: Not applicable } \\
\hline Bjerkenstedt 2005 & 54 & $-9.9(9.1)$ & 54 & $-8.4(8.9)$ & 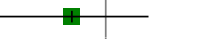 & $39.22 \%$ & $-1.5[-4.89,1.89]$ \\
\hline Szegedi 2005 & 122 & $-16.4(10.7)$ & 122 & $-12.6(10.6)$ & 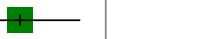 & $60.78 \%$ & $-3.8[-6.47,-1.13]$ \\
\hline 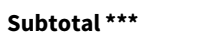 & 176 & & 176 & & & $100 \%$ & $-2.9[-5.1,-0.7]$ \\
\hline \multicolumn{8}{|c|}{ Heterogeneity: $\operatorname{Tau}^{2}=0.22 ; \mathrm{Chi}^{2}=1.09, \mathrm{df}=1(\mathrm{P}=0.3) ; \mathrm{I}^{2}=8.13 \%$} \\
\hline \multicolumn{8}{|c|}{ Test for overall effect: $Z=2.58(P=0.01)$} \\
\hline \multicolumn{8}{|c|}{ Heterogeneity: $\mathrm{Tau}^{2}=0.22 ; \mathrm{Chi}^{2}=1.09, \mathrm{df}=1(\mathrm{P}=0.3) ; \mathrm{I}^{2}=8.13 \%$} \\
\hline \multicolumn{8}{|c|}{ Test for overall effect: $Z=2.58(P=0.01)$} \\
\hline Test for subgroup dif & licabl & & & & & & \\
\hline
\end{tabular}

Analysis 5.8. Comparison 5 Hypericum mono-preparations vs. standard antidepressants. B. Continuous measures, Outcome 8 Mean HAMD after treatment in studies from German-speaking countries and other studies.

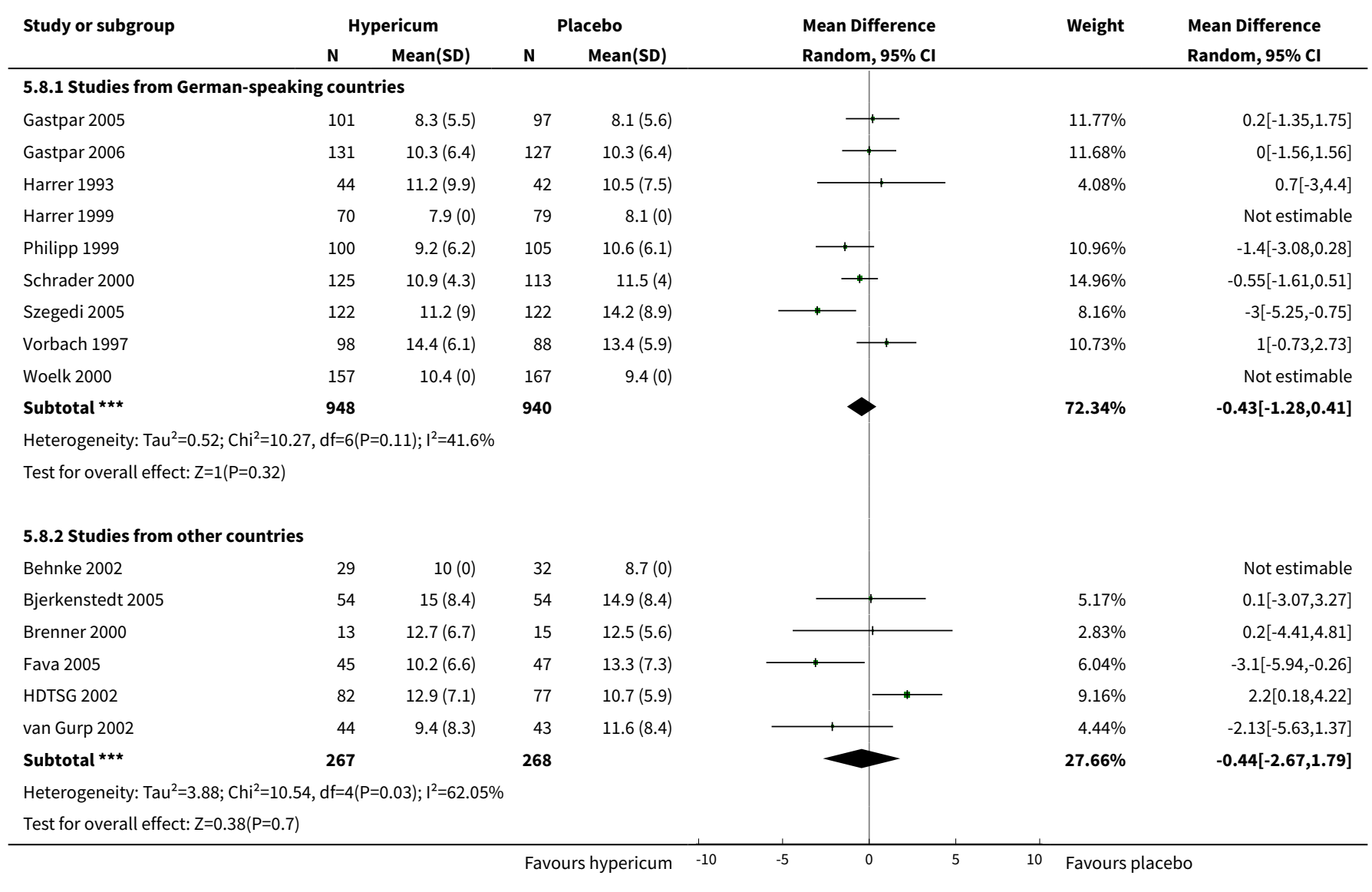

St John's wort for major depression (Review) 


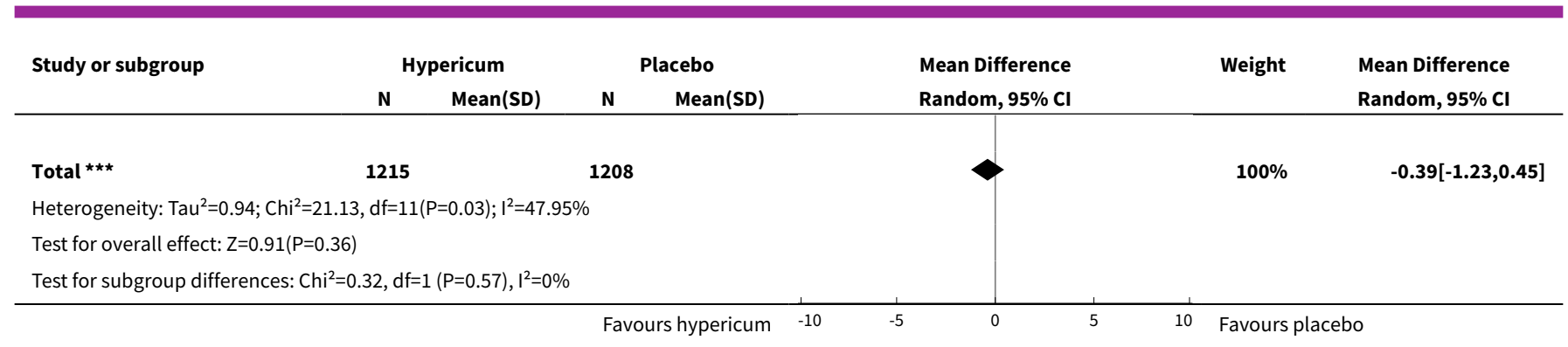

Analysis 5.9. Comparison 5 Hypericum mono-preparations vs. standard antidepressants. B. Continuous measures, Outcome 9 Mean D-S (Depression Scale von Zerssen) scores after therapy.

\begin{tabular}{|c|c|c|c|c|c|c|c|}
\hline \multirow[t]{2}{*}{ Study or subgroup } & \multicolumn{2}{|c|}{ hypericum } & \multicolumn{2}{|c|}{ standard } & \multirow{2}{*}{$\begin{array}{l}\text { Mean Difference } \\
\text { Random, } 95 \% \mathrm{Cl}\end{array}$} & \multirow[t]{2}{*}{ Weight } & \multirow{2}{*}{$\begin{array}{l}\text { Mean Difference } \\
\text { Random, } 95 \% \mathrm{Cl}\end{array}$} \\
\hline & $\mathbf{N}$ & Mean(SD) & $\mathbf{N}$ & Mean(SD) & & & \\
\hline \multicolumn{8}{|c|}{ 5.9.1 vs. older antidepressants } \\
\hline Harrer 1993 & 44 & $16.1(15)$ & 42 & $13.9(12)$ & & $10.26 \%$ & $2.2[-3.53,7.93]$ \\
\hline Vorbach 1997 & 98 & $16.5(8.4)$ & 88 & $13.6(6.8)$ & & $70.36 \%$ & $2.9[0.71,5.09]$ \\
\hline Subtotal $\star \star \star$ & 142 & & 130 & & & $80.62 \%$ & $2.81[0.77,4.85]$ \\
\hline \multicolumn{8}{|c|}{ Heterogeneity: $\operatorname{Tau}^{2}=0 ; \mathrm{Chi}^{2}=0.05, \mathrm{df}=1(\mathrm{P}=0.82) ; \mathrm{I}^{2}=0 \%$} \\
\hline \multicolumn{8}{|c|}{ Test for overall effect: $Z=2.7(P=0.01)$} \\
\hline \multicolumn{8}{|l|}{ 5.9.2 vs. SSRIs } \\
\hline Behnke 2002 & 29 & $14.3(10.4)$ & 32 & $12.4(8.3)$ & & $14.9 \%$ & $1.9[-2.85,6.65]$ \\
\hline Brenner 2000 & 12 & $18.4(12.1)$ & 15 & $15.9(10.5)$ & & $4.48 \%$ & $2.5[-6.17,11.17]$ \\
\hline Subtotal $\star \star \star$ & 41 & & 47 & & & $19.38 \%$ & $2.04[-2.13,6.21]$ \\
\hline \multicolumn{8}{|c|}{ Heterogeneity: $\operatorname{Tau}^{2}=0 ; \mathrm{Chi}^{2}=0.01, \mathrm{df}=1(\mathrm{P}=0.91) ; \mathrm{I}^{2}=0 \%$} \\
\hline Total ${ }^{\star \star \star}$ & 183 & & 177 & & & $100 \%$ & $2.66[0.83,4.5]$ \\
\hline \multicolumn{8}{|c|}{ Heterogeneity: $\mathrm{Tau}^{2}=0 ; \mathrm{Chi}^{2}=0.17, \mathrm{df}=3(\mathrm{P}=0.98) ; \mathrm{I}^{2}=0 \%$} \\
\hline \multicolumn{8}{|c|}{ Test for overall effect: $Z=2.84(P=0)$} \\
\hline \multicolumn{8}{|c|}{ Test for subgroup differences: $\mathrm{Chi}^{2}=0.11, \mathrm{df}=1(\mathrm{P}=0.74), \mathrm{I}^{2}=0 \%$} \\
\hline
\end{tabular}

Analysis 5.10. Comparison 5 Hypericum mono-preparations vs. standard antidepressants. B. Continuous measures, Outcome 10 Various self-rating scales.

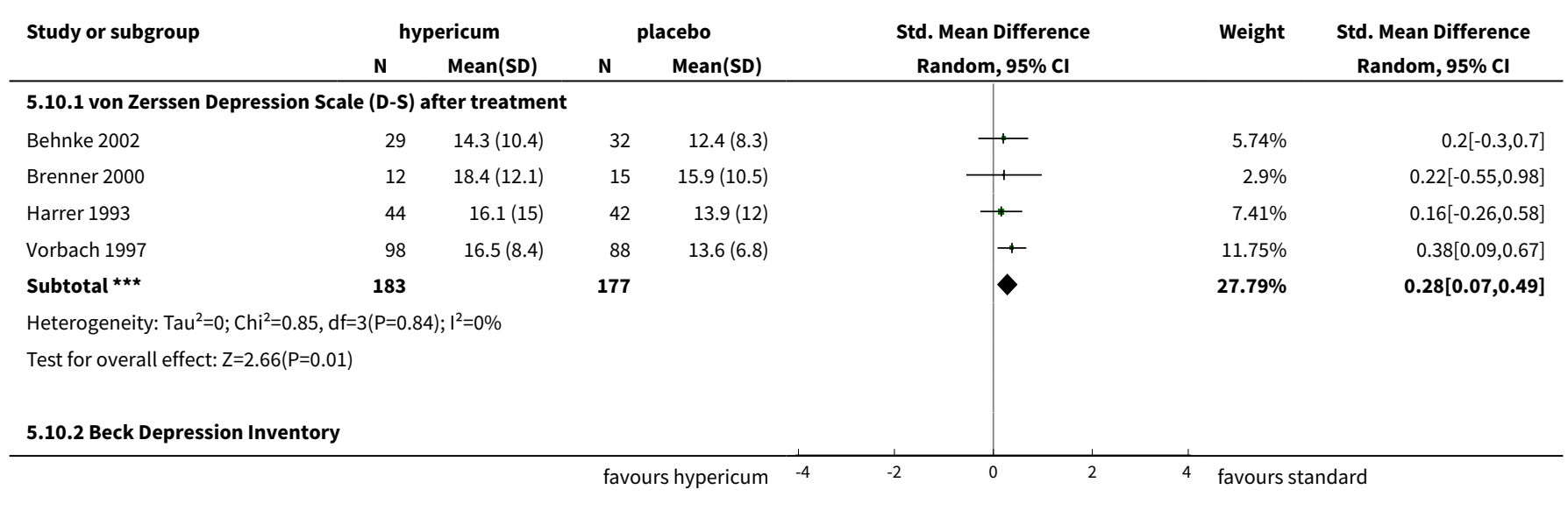

St John's wort for major depression (Review) 


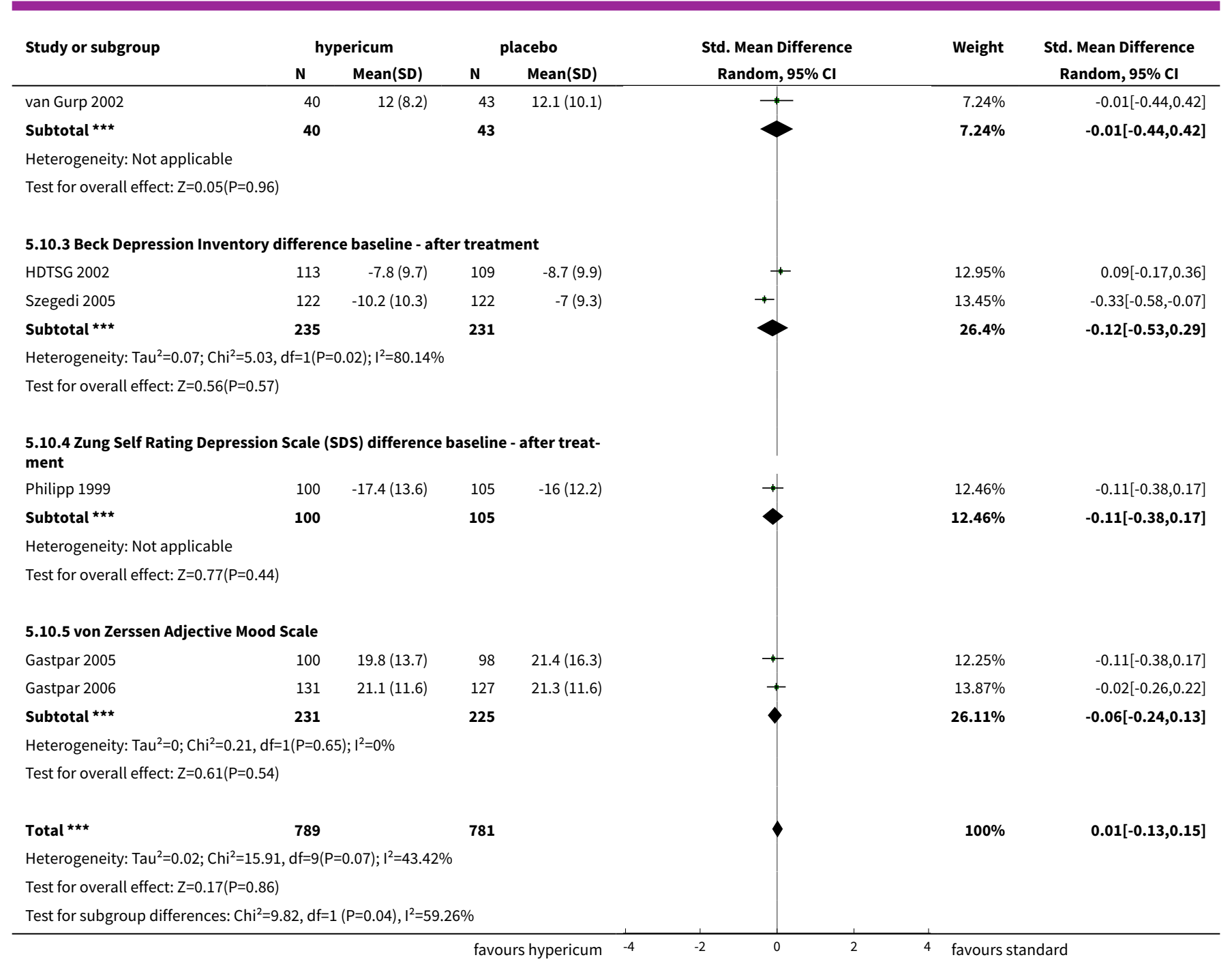

Analysis 5.11. Comparison 5 Hypericum mono-preparations vs. standard antidepressants. B. Continuous measures, Outcome 11 Various self-rating scales in studies from German-speaking countries and other countries.

\begin{tabular}{|c|c|c|c|c|c|c|c|}
\hline \multirow[t]{2}{*}{ Study or subgroup } & \multicolumn{2}{|c|}{ hypericum } & \multicolumn{2}{|c|}{ placebo } & \multirow{2}{*}{$\begin{array}{c}\text { Std. Mean Difference } \\
\text { Random, } 95 \% \mathrm{Cl}\end{array}$} & \multirow[t]{2}{*}{ Weight } & \multirow{2}{*}{$\begin{array}{c}\text { Std. Mean Difference } \\
\text { Random, } 95 \% \mathrm{Cl}\end{array}$} \\
\hline & $\mathbf{N}$ & Mean(SD) & $\mathbf{N}$ & Mean(SD) & & & \\
\hline \multicolumn{8}{|c|}{ 5.11.1 Studies from German-speaking countries } \\
\hline Gastpar 2006 & 131 & $21.1(11.6)$ & 127 & $21.3(11.6)$ & + & $13.87 \%$ & $-0.02[-0.26,0.22]$ \\
\hline Harrer 1993 & 44 & $16.1(15)$ & 42 & $13.9(12)$ & $\rightarrow$ & $7.41 \%$ & $0.16[-0.26,0.58]$ \\
\hline Philipp 1999 & 100 & $-17.4(13.6)$ & 105 & $-16(12.2)$ & $\rightarrow$ & $12.46 \%$ & $-0.11[-0.38,0.17]$ \\
\hline Szegedi 2005 & 122 & $-10.2(10.3)$ & 122 & $-7(9.3)$ & + & $13.45 \%$ & $-0.33[-0.58,-0.07]$ \\
\hline Vorbach 1997 & 98 & $16.5(8.4)$ & 88 & $13.6(6.8)$ & + & $11.75 \%$ & $0.38[0.09,0.67]$ \\
\hline Subtotal $\star \star \star ~$ & 595 & & 582 & & $>$ & $71.18 \%$ & $-0.02[-0.21,0.18]$ \\
\hline \multicolumn{8}{|c|}{ Heterogeneity: $\operatorname{Tau}^{2}=0.04 ; \mathrm{Chi}^{2}=14.1, \mathrm{df}=5(\mathrm{P}=0.01) ; \mathrm{I}^{2}=64.54 \%$} \\
\hline \multicolumn{8}{|c|}{ Test for overall effect: $Z=0.19(P=0.85)$} \\
\hline \multicolumn{8}{|c|}{ 5.11.2 Studies from other countries } \\
\hline
\end{tabular}




\begin{tabular}{|c|c|c|c|c|c|c|c|}
\hline \multirow[t]{2}{*}{ Study or subgroup } & \multicolumn{2}{|c|}{ hypericum } & \multicolumn{2}{|c|}{ placebo } & \multirow{2}{*}{$\begin{array}{c}\text { Std. Mean Difference } \\
\text { Random, } 95 \% \mathrm{Cl}\end{array}$} & \multirow[t]{2}{*}{ Weight } & \multirow{2}{*}{$\begin{array}{c}\text { Std. Mean Difference } \\
\text { Random, } 95 \% \mathrm{Cl}\end{array}$} \\
\hline & $\mathbf{N}$ & Mean(SD) & $\mathbf{N}$ & Mean(SD) & & & \\
\hline Behnke 2002 & 29 & $14.3(10.4)$ & 32 & $12.4(8.3)$ & 1 & $5.74 \%$ & $0.2[-0.3,0.7]$ \\
\hline Brenner 2000 & 12 & $18.4(12.1)$ & 15 & $15.9(10.5)$ & +1 & $2.9 \%$ & $0.22[-0.55,0.98]$ \\
\hline HDTSG 2002 & 113 & $-7.8(9.7)$ & 109 & $-8.7(9.9)$ & + & $12.95 \%$ & $0.09[-0.17,0.36]$ \\
\hline van Gurp 2002 & 40 & $12(8.2)$ & 43 & $12.1(10.1)$ & $\rightarrow$ & $7.24 \%$ & $-0.01[-0.44,0.42]$ \\
\hline Subtotal $* \star \star$ & 194 & & 199 & & 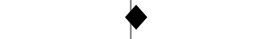 & $28.82 \%$ & $0.1[-0.1,0.29]$ \\
\hline \multicolumn{8}{|c|}{ Heterogeneity: $\operatorname{Tau}^{2}=0 ; \mathrm{Chi}^{2}=0.5, \mathrm{df}=3(\mathrm{P}=0.92) ; \mathrm{I}^{2}=0 \%$} \\
\hline \multicolumn{8}{|c|}{ Test for overall effect: $\mathrm{Z}=0.95(\mathrm{P}=0.34)$} \\
\hline Total $\star \star \star ~$ & 789 & & 781 & & 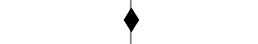 & $100 \%$ & $0.01[-0.13,0.15]$ \\
\hline \multicolumn{8}{|c|}{ Heterogeneity: $\operatorname{Tau}^{2}=0.02 ; \mathrm{Chi}^{2}=15.91, \mathrm{df}=9(\mathrm{P}=0.07) ; \mathrm{I}^{2}=43.42 \%$} \\
\hline \multicolumn{8}{|c|}{ Test for overall effect: $Z=0.17(P=0.86)$} \\
\hline \multicolumn{8}{|c|}{ Test for subgroup differences: $\mathrm{Chi}^{2}=1.31, \mathrm{df}=1(\mathrm{P}=0.25), \mathrm{I}^{2}=23.6 \%$} \\
\hline
\end{tabular}

Comparison 6. Safety - Hypericum mono-preparations vs. standard antidepressants

\begin{tabular}{|c|c|c|c|c|}
\hline Outcome or subgroup title & $\begin{array}{l}\text { No. of } \\
\text { studies }\end{array}$ & $\begin{array}{l}\text { No. of } \\
\text { partici- } \\
\text { pants }\end{array}$ & Statistical method & Effect size \\
\hline $\begin{array}{l}1 \text { Number of patients discontin- } \\
\text { uing treatment/dropping out } \\
\text { due to adverse/side effects }\end{array}$ & 16 & 2785 & Odds Ratio (M-H, Random, 95\% Cl) & $0.41[0.29,0.60]$ \\
\hline 1.1 vs. older antidepressants & 5 & 1016 & Odds Ratio (M-H, Random, 95\% Cl) & $0.24[0.13,0.46]$ \\
\hline 1.2 vs. SSRIs & 11 & 1769 & Odds Ratio (M-H, Random, 95\% Cl) & $0.53[0.34,0.83]$ \\
\hline $\begin{array}{l}2 \text { Number of patients dropping } \\
\text { out }\end{array}$ & 16 & 2785 & Odds Ratio (M-H, Random, 95\% Cl) & $0.77[0.62,0.95]$ \\
\hline 2.1 vs. older antidperessants & 5 & 1016 & Odds Ratio (M-H, Random, 95\% Cl) & $0.67[0.47,0.95]$ \\
\hline 2.2 vs. SSRIs & 11 & 1769 & Odds Ratio (M-H, Random, 95\% Cl) & $0.83[0.63,1.08]$ \\
\hline $\begin{array}{l}3 \text { Number of patients reporting } \\
\text { adverse effects }\end{array}$ & 14 & 2663 & Odds Ratio (M-H, Random, 95\% Cl) & $0.56[0.43,0.74]$ \\
\hline $3.1 \mathrm{vs.} \mathrm{older} \mathrm{antidepressants}$ & 5 & 1016 & Odds Ratio (M-H, Random, 95\% Cl) & $0.39[0.30,0.50]$ \\
\hline 3.2 vs. SSRIs & 9 & 1647 & Odds Ratio (M-H, Random, 95\% Cl) & $0.70[0.49,1.00]$ \\
\hline
\end{tabular}

Analysis 6.1. Comparison 6 Safety - Hypericum mono-preparations vs. standard antidepressants, Outcome 1 Number of patients discontinuing treatment/dropping out due to adverse/side effects.

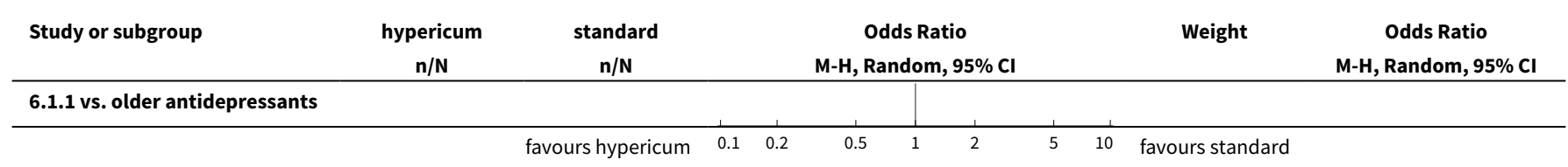




\begin{tabular}{|c|c|c|c|c|c|}
\hline Study or subgroup & $\begin{array}{c}\text { hypericum } \\
\mathrm{n} / \mathrm{N}\end{array}$ & $\begin{array}{c}\text { standard } \\
\mathrm{n} / \mathrm{N}\end{array}$ & $\begin{array}{c}\text { Odds Ratio } \\
\text { M-H, Random, } 95 \% \mathrm{CI}\end{array}$ & Weight & $\begin{array}{c}\text { Odds Ratio } \\
\text { M-H, Random, } 95 \% \mathrm{Cl}\end{array}$ \\
\hline Harrer 1993 & $0 / 51$ & $2 / 51$ & & $1.44 \%$ & $0.19[0.01,4.11]$ \\
\hline Philipp 1999 & $0 / 106$ & $1 / 110$ & & $1.31 \%$ & $0.34[0.01,8.51]$ \\
\hline Vorbach 1997 & $1 / 107$ & $8 / 102$ & & $3.08 \%$ & $0.11[0.01,0.9]$ \\
\hline Wheatley 1997 & $7 / 87$ & $13 / 78$ & 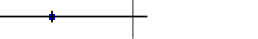 & $14.23 \%$ & $0.44[0.16,1.16]$ \\
\hline Woelk 2000 & $4 / 157$ & $26 / 167$ & & $11.66 \%$ & $0.14[0.05,0.42]$ \\
\hline Subtotal $(95 \% \mathrm{Cl})$ & 508 & 508 & & $31.73 \%$ & $0.24[0.13,0.46]$ \\
\hline \multicolumn{6}{|c|}{ Total events: 12 (hypericum), 50 (standard) } \\
\hline \multicolumn{6}{|c|}{ Heterogeneity: $\operatorname{Tau}^{2}=0 ; \mathrm{Chi}^{2}=3.03, \mathrm{df}=4(\mathrm{P}=0.55) ; \mathrm{I}^{2}=0 \%$} \\
\hline \multicolumn{6}{|c|}{ Test for overall effect: $Z=4.27(P<0.0001)$} \\
\hline \multicolumn{6}{|l|}{6.1 .2 vs. SSRIs } \\
\hline Behnke 2002 & $2 / 35$ & $2 / 35$ & & $3.32 \%$ & $1[0.13,7.53]$ \\
\hline Bjerkenstedt 2005 & $4 / 57$ & $4 / 56$ & & $6.55 \%$ & $0.98[0.23,4.13]$ \\
\hline Brenner 2000 & $2 / 15$ & $2 / 15$ & & $3.05 \%$ & $1[0.12,8.21]$ \\
\hline Fava 2005 & $0 / 45$ & $2 / 47$ & & $1.44 \%$ & $0.2[0.01,4.28]$ \\
\hline Gastpar 2005 & $5 / 123$ & $10 / 118$ & - & $11.09 \%$ & $0.46[0.15,1.38]$ \\
\hline Gastpar 2006 & $4 / 131$ & $11 / 127$ & $\mathrm{~T}$ & $9.86 \%$ & $0.33[0.1,1.07]$ \\
\hline Harrer 1999 & $6 / 77$ & $8 / 84$ & & $11.05 \%$ & $0.8[0.27,2.43]$ \\
\hline HDTSG 2002 & $2 / 113$ & $5 / 111$ & & $4.9 \%$ & $0.38[0.07,2.01]$ \\
\hline Schrader 2000 & $0 / 125$ & $1 / 114$ & & $1.31 \%$ & $0.3[0.01,7.47]$ \\
\hline Szegedi 2005 & $4 / 125$ & $8 / 126$ & & $9 \%$ & $0.49[0.14,1.66]$ \\
\hline van Gurp 2002 & $3 / 45$ & $7 / 45$ & & $6.7 \%$ & $0.39[0.09,1.61]$ \\
\hline Subtotal $(95 \% \mathrm{Cl})$ & 891 & 878 & & $68.27 \%$ & $0.53[0.34,0.83]$ \\
\hline \multicolumn{6}{|c|}{ Total events: 32 (hypericum), 60 (standard) } \\
\hline \multicolumn{6}{|c|}{ Heterogeneity: $\operatorname{Tau}^{2}=0 ; \mathrm{Chi}^{2}=3.52, \mathrm{df}=10(\mathrm{P}=0.97) ; \mathrm{I}^{2}=0 \%$} \\
\hline \multicolumn{6}{|c|}{ Test for overall effect: $Z=2.8(P=0.01)$} \\
\hline Total $(95 \% \mathrm{Cl})$ & 1399 & 1386 & & $100 \%$ & $0.41[0.29,0.6]$ \\
\hline \multicolumn{6}{|c|}{ Total events: 44 (hypericum), 110 (standard) } \\
\hline \multicolumn{6}{|c|}{ Heterogeneity: $\operatorname{Tau}^{2}=0 ; \mathrm{Chi}^{2}=10.42, \mathrm{df}=15(\mathrm{P}=0.79) ; \mathrm{I}^{2}=0 \%$} \\
\hline \multicolumn{6}{|c|}{ Test for overall effect: $Z=4.72(P<0.0001)$} \\
\hline Test for subgroup dif & licable & & & & \\
\hline
\end{tabular}

Analysis 6.2. Comparison 6 Safety - Hypericum mono-preparations vs. standard antidepressants, Outcome 2 Number of patients dropping out.

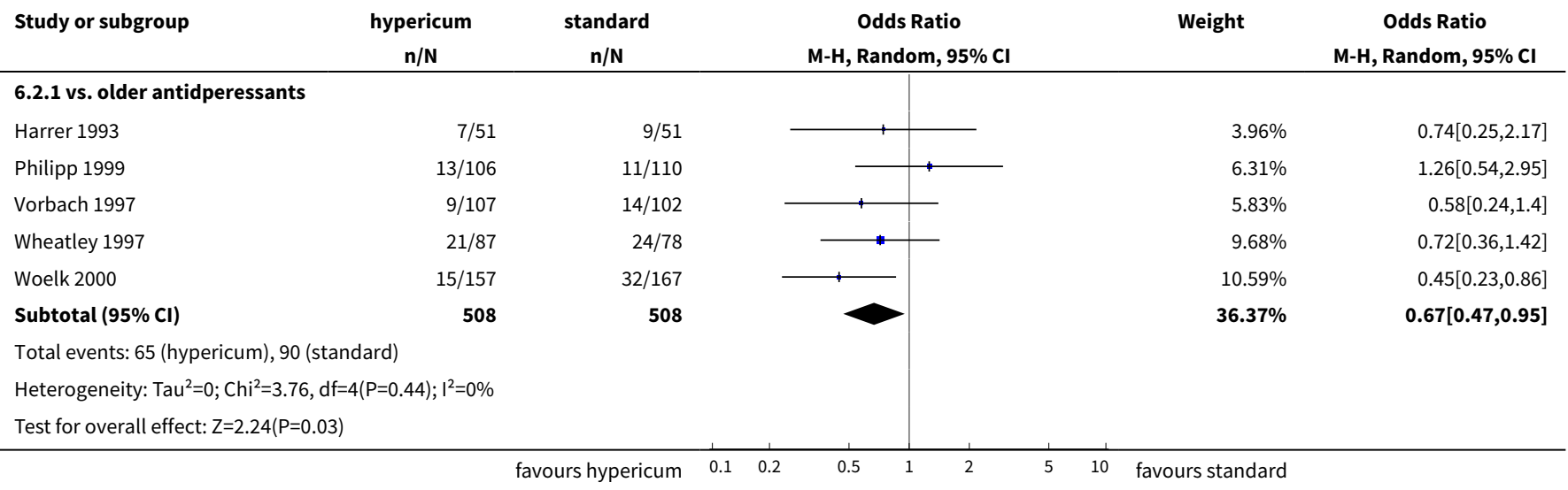

St John's wort for major depression (Review) 


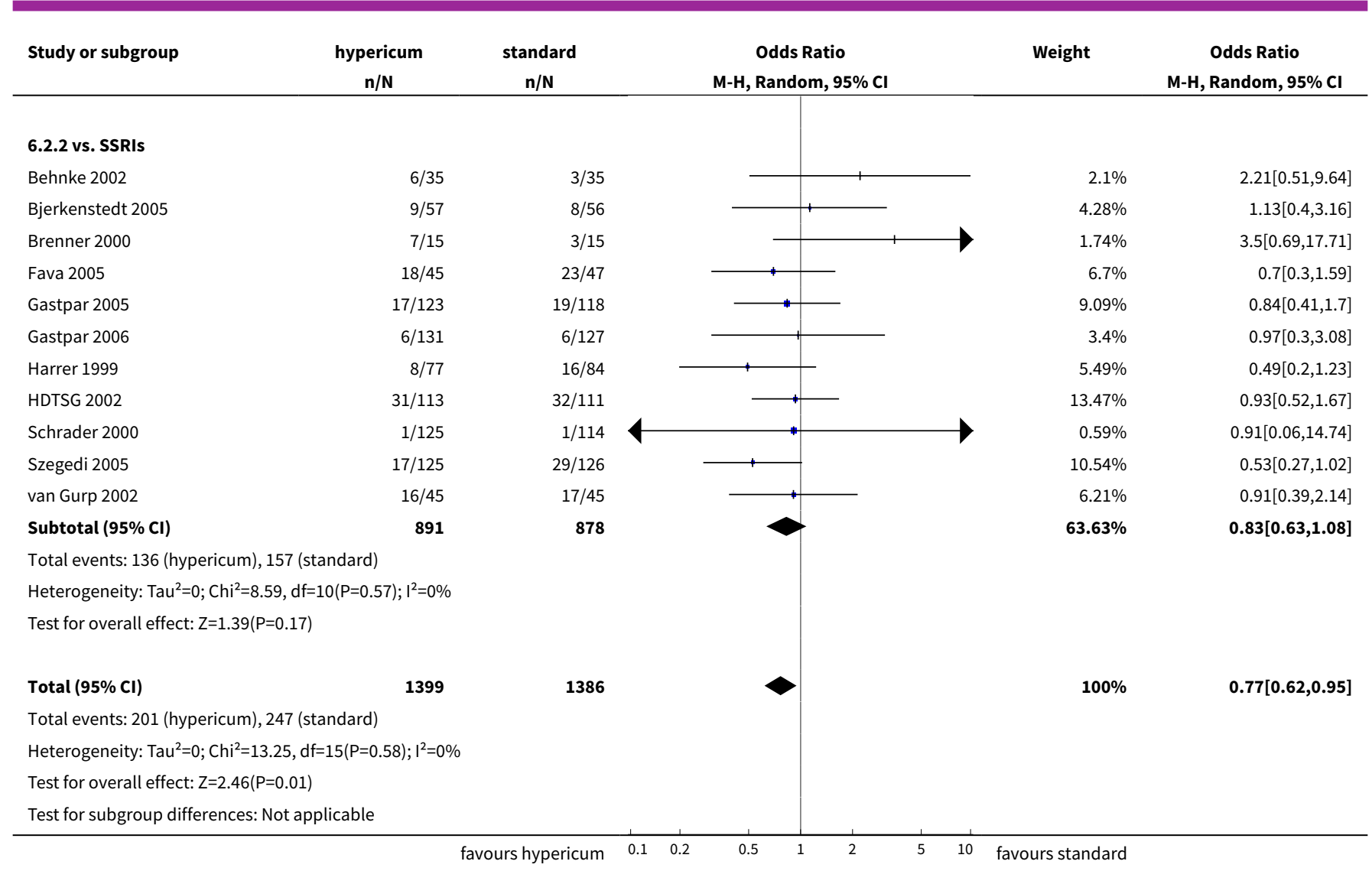

Analysis 6.3. Comparison 6 Safety - Hypericum mono-preparations vs. standard antidepressants, Outcome 3 Number of patients reporting adverse effects.

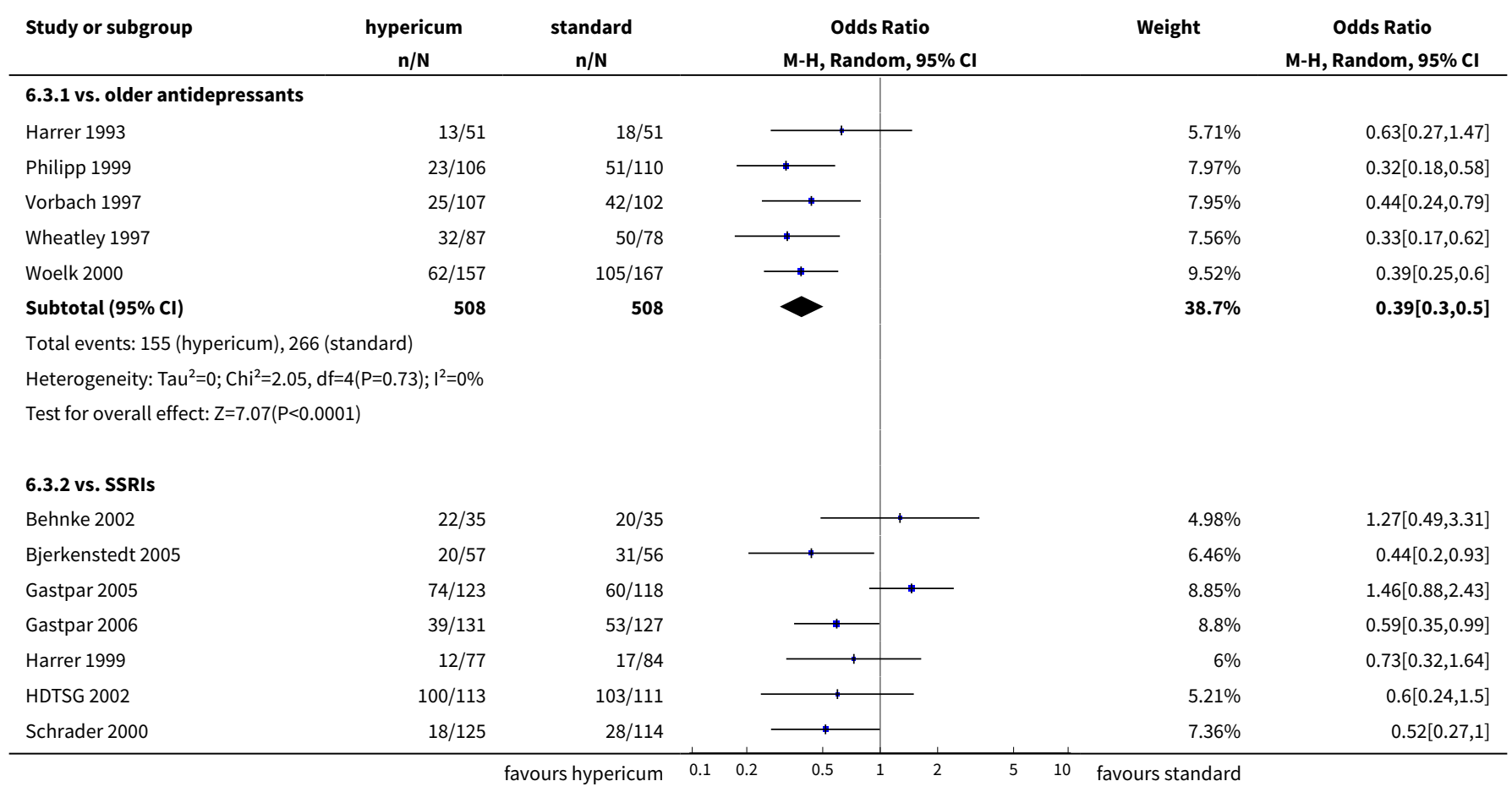

St John's wort for major depression (Review) 


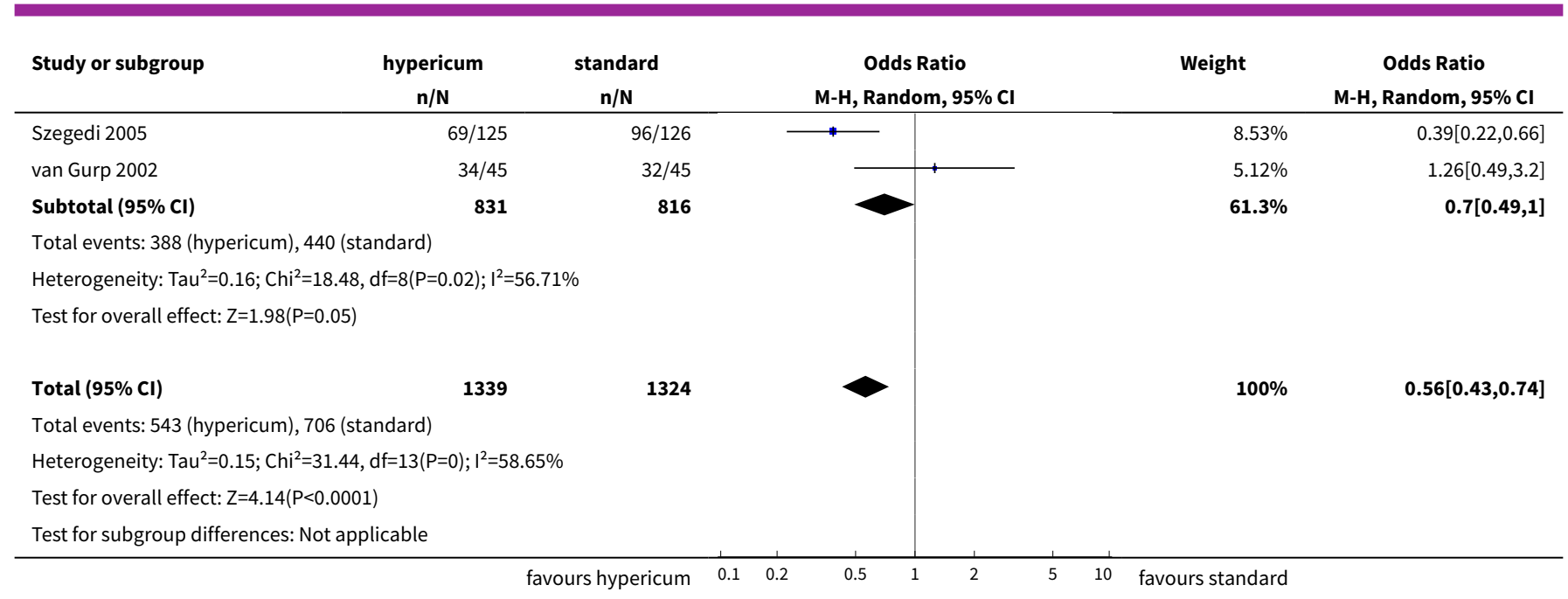

\section{APPENDICES}

\section{Appendix 1. Summary of meta-regression analyses}

Table 1: Univariable meta-regression analysis of response rate ratio (relative risk of response) in comparison to placebo

\begin{tabular}{llllll}
\hline $\begin{array}{l}\text { Explana- } \\
\text { tory vari- } \\
\text { able }\end{array}$ & $\begin{array}{l}\text { Coeffi- } \\
\text { cient (B) }\end{array}$ & $\begin{array}{l}95 \% \text { con- } \\
\text { fidence in- } \\
\text { terval }\end{array}$ & $\begin{array}{l}\text { Statisti- } \\
\text { cal signifi- } \\
\text { cance }(\mathrm{p})\end{array}$ & $\begin{array}{l}\text { Propor- } \\
\text { tion of } \\
\text { hetero- } \\
\text { geneity } \\
\text { explained } \\
\left(\mathrm{R}^{2}\right)\end{array}$ & Interpretation \\
\hline Country & 0.53 & 0.20 to & .002 & 0.29 & $\begin{array}{l}\text { Studies form German-speaking countries result statistically sig- } \\
\text { nificant in 0.53 higher effect size estimates on average than stud- } \\
\text { ies form non-German-speaking countries. }\end{array}$ \\
\hline $\begin{array}{lllll}\text { Precision } \\
0.86\end{array}$ & -0.11 & -0.21 to & .032 & 0.16 & $\begin{array}{l}\text { Studies with one unit increase in precision (1/SE) result statisti- } \\
\text { cally significant in 0.11 lower effect size estimates on average. }\end{array}$ \\
\hline $\begin{array}{l}\text { Baseline } \\
\text { HAMD }\end{array}$ & -0.12 & -0.01 & & 0.16 & $\begin{array}{l}\text { Studies with one point increase in mean baseline HAMD severity } \\
\text { result statistically significant in } 0.12 \text { lower effect size estimates } \\
\text { on average. }\end{array}$ \\
\hline
\end{tabular}

Table 2: Multiple meta-regression analysis of response rate ratio (relative risk of response) in comparison to placebo

\begin{tabular}{llllll}
\hline $\begin{array}{l}\text { Explana- } \\
\text { tory vari- } \\
\text { able }\end{array}$ & $\begin{array}{llll}\text { Coeffi- } \\
\text { cient (B) }\end{array}$ & $\begin{array}{l}\text { 95\% con- } \\
\text { fidence in- } \\
\text { terval }\end{array}$ & $\begin{array}{l}\text { Statisti- } \\
\text { cal signifi- } \\
\text { cance }(\mathrm{p})\end{array}$ & $\begin{array}{l}\text { Propor- } \\
\text { tion of } \\
\text { hetero- }\end{array}$ & Interpretation \\
& & & & geneity
\end{tabular}


(Continued)

explained

(Beta $\left.{ }^{2}\right)$

\begin{tabular}{|c|c|c|c|c|c|}
\hline Country & 0.32 & $\begin{array}{l}0.02 \text { to } \\
0.61\end{array}$ & .035 & 0.13 & $\begin{array}{l}\text { Studies form German-speaking countries result statistically sig- } \\
\text { nificant in } 0.32 \text { higher effect size estimates on average than stud- } \\
\text { ies form non-German-speaking countries. }\end{array}$ \\
\hline Precision & -0.09 & $\begin{array}{l}-0.18 \text { to } \\
-0.02\end{array}$ & .017 & 0.17 & $\begin{array}{l}\text { Studies with one unit increase in precision ( } 1 / \mathrm{SE} \text { ) result statisti- } \\
\text { cally significant in } 0.09 \text { lower effect size estimates on average. }\end{array}$ \\
\hline $\begin{array}{l}\text { Baseline } \\
\text { HAMD }\end{array}$ & -0.07 & $\begin{array}{l}-0.16 \text { to } \\
0.03\end{array}$ & .161 & 0.06 & No statistically significant association was found. \\
\hline
\end{tabular}

Table 3: Univariable meta-regression analysis of response rate ratio (relative risk of response) in comparison to standard antidepressants

\begin{tabular}{|c|c|c|c|c|c|}
\hline $\begin{array}{l}\text { Explana- } \\
\text { tory vari- } \\
\text { able }\end{array}$ & $\begin{array}{l}\text { Coeffi- } \\
\text { cient (B) }\end{array}$ & $\begin{array}{l}95 \% \text { con- } \\
\text { fidence in- } \\
\text { terval }\end{array}$ & $\begin{array}{l}\text { Statisti- } \\
\text { cal signifi- } \\
\text { cance }(p)\end{array}$ & $\begin{array}{l}\text { Proportion } \\
\text { of hetero- } \\
\text { geneity ex- } \\
\text { plained }\left(R^{2}\right)\end{array}$ & Interpretation \\
\hline Country & 0.18 & 0.01 to 0.36 & .037 & 0.23 & $\begin{array}{l}\text { Studies form German-speaking countries result statistically } \\
\text { significant in } 0.18 \text { higher effect size estimates on average than } \\
\text { studies form non-German-speaking countries. }\end{array}$ \\
\hline Precision & 0.03 & 0 to 0.06 & .065 & 0.18 & No statistically significant association was found. \\
\hline $\begin{array}{l}\text { Baseline } \\
\text { HAMD }\end{array}$ & 0.01 & $\begin{array}{l}-0.02 \text { to } \\
0.04\end{array}$ & .546 & 0.02 & No statistically significant association was found. \\
\hline
\end{tabular}

Table 4: Multiple meta-regression analysis of response rate ratio (relative risk of response) in comparison to standard antidepressants

\begin{tabular}{llllll}
\hline $\begin{array}{l}\text { Explanatory } \\
\text { variable }\end{array}$ & $\begin{array}{l}\text { Coeffi- } \\
\text { cient (B) }\end{array}$ & $\begin{array}{l}\text { 95\% confidence } \\
\text { interval }\end{array}$ & $\begin{array}{l}\text { Statisti- } \\
\text { cal signifi- } \\
\text { cance }(\mathrm{p})\end{array}$ & $\begin{array}{l}\text { Proportion of } \\
\text { heterogeneity } \\
\text { explained (Be- } \\
\left.\mathrm{ta}^{2}\right)\end{array}$ & Interpretation \\
\hline Country & 0.14 & -0.10 to 0.38 & .244 & 0.17 & No statistically significant association was found. \\
\hline $\begin{array}{l}\text { Precision } \\
\begin{array}{l}\text { Baseline } \\
\text { HAMD }\end{array}\end{array}$ & 0.01 & -0.04 to 0.05 & .832 & 0.01 & No statistically significant association was found. \\
\hline
\end{tabular}


Table 5: Univariable meta-regression analysis of mean difference in post-treatment HAMD scores in placebo comparisons

\begin{tabular}{llllll}
\hline $\begin{array}{l}\text { Explana- } \\
\text { tory vari- } \\
\text { able }\end{array}$ & $\begin{array}{l}\text { Coeffi- } \\
\text { cient }(\mathrm{B})\end{array}$ & $\begin{array}{l}\text { 95\% confi- } \\
\text { dence inter- } \\
\text { val }\end{array}$ & $\begin{array}{l}\text { Statisti- } \\
\text { cal signifi- } \\
\text { cance }(\mathrm{p})\end{array}$ & $\begin{array}{l}\text { Propor- } \\
\text { tion of } \\
\text { hetero- } \\
\text { geneity } \\
\text { explained } \\
\left(\mathrm{R}^{2}\right)\end{array}$ & Interpretation \\
\hline Country & 3.80 & 1.95 to 5.66 & $<.001$ & 0.54 & $\begin{array}{l}\text { Studies form German-speaking countries result statistically } \\
\text { significant in 3.80 HAMD points higher effect size estimates on } \\
\text { average than studies form non-German-speaking countries. }\end{array}$ \\
\hline $\begin{array}{l}\text { Precision } \\
\text { Baseline }\end{array}$ & 3.02 & -2.10 to 8.15 & .247 & 0.09 & No statistically significant association was found. \\
\hline HAMD & -0.57 & -1.27 to 0.14 & .117 & 0.15 & No statistically significant association was found. \\
\hline
\end{tabular}

Table 6: Multiple meta-regression analysis of mean difference in post-treatment HAMD scores in placebo comparisons

\begin{tabular}{llllll}
\hline $\begin{array}{l}\text { Explana- } \\
\text { tory vari- } \\
\text { able }\end{array}$ & $\begin{array}{l}\text { Coeffi- } \\
\text { cient }(\mathrm{B})\end{array}$ & $\begin{array}{l}\text { 95\% confi- } \\
\text { dence inter- } \\
\text { val }\end{array}$ & $\begin{array}{l}\text { Statisti- } \\
\text { cal signifi- } \\
\text { cance }(\mathrm{p})\end{array}$ & $\begin{array}{l}\text { Proportion } \\
\text { of hetero- } \\
\text { geneity ex- } \\
\text { plained } \\
\text { (Beta2) }\end{array}$ & Interpretation \\
\hline Country & 3.52 & 1.70 to 5.33 & $<.001$ & 0.46 & $\begin{array}{l}\text { Studies form German-speaking countries result statistically } \\
\text { significant in 3.52 HAMD points higher effect size estimates } \\
\text { on average than studies form non-German-speaking coun- } \\
\text { tries. }\end{array}$ \\
\hline $\begin{array}{lllll}\text { Precision } \\
\text { Baseline }\end{array}$ & 2.43 & -1.14 to 5.99 & .183 & 0.05 & No statistically significant association was found. \\
HAMD & 0.24 & -0.76 to 0.29 & .378 & 0.03 & No statistically significant association was found. \\
\hline
\end{tabular}

Table 7: Univariable meta-regression analysis of mean difference in post-treatment HAMD scores in standard antidepressant comparisons

\begin{tabular}{|c|c|c|c|c|c|}
\hline $\begin{array}{l}\text { Explana- } \\
\text { tory vari- } \\
\text { able }\end{array}$ & $\begin{array}{l}\text { Coeffi- } \\
\text { cient (B) }\end{array}$ & $\begin{array}{l}95 \% \text { confi- } \\
\text { dence inter- } \\
\text { val }\end{array}$ & $\begin{array}{l}\text { Statisti- } \\
\text { cal signifi- } \\
\text { cance }(p)\end{array}$ & $\begin{array}{l}\text { Propor- } \\
\text { tion of } \\
\text { hetero- } \\
\text { geneity } \\
\text { explained } \\
\left(R^{2}\right)\end{array}$ & Interpretation \\
\hline
\end{tabular}




\begin{tabular}{|c|c|c|c|c|c|}
\hline Country & 0.02 & -1.64 to 1.68 & .982 & 0 & No statistically significant association was found. \\
\hline Precision & 0.04 & -1.71 to 1.79 & .966 & 0 & No statistically significant association was found. \\
\hline $\begin{array}{l}\text { Baseline } \\
\text { HAMD }\end{array}$ & -0.24 & -0.48 to 0 & .045 & 0.26 & $\begin{array}{l}\text { Studies with one point increase in mean baseline HAMD sever- } \\
\text { ity result statistically significant in } 0.24 \text { lower effect size esti- } \\
\text { mates on average. }\end{array}$ \\
\hline
\end{tabular}

Table 8: Multiple meta-regression analysis of mean difference in post-treatment HAMD scores in standard antidepressant comparisons

\begin{tabular}{llllll}
\hline $\begin{array}{l}\text { Explana- } \\
\text { tory vari- } \\
\text { able }\end{array}$ & $\begin{array}{l}\text { Coeffi- } \\
\text { cient (B) }\end{array}$ & $\begin{array}{l}\text { 95\% confi- } \\
\text { dence interval }\end{array}$ & $\begin{array}{l}\text { Statisti- } \\
\text { cal signifi- } \\
\text { cance }(\mathrm{p})\end{array}$ & $\begin{array}{l}\text { Proportion } \\
\text { of hetero- } \\
\text { geneity ex- } \\
\text { plained (Be- } \\
\left.\text { ta }{ }^{2}\right)\end{array}$ & Interpretation \\
\hline Country & 1.34 & -0.76 to 3.45 & .211 & 0.22 & No statistically significant association was found. \\
\hline Precision & -2.11 & -4.62 to 0.40 & .099 & 0.60 & No statistically significant association was found. \\
\hline $\begin{array}{l}\text { Baseline } \\
\text { HAMD }\end{array}$ & -0.45 & -0.79 to 0.11 & .010 & 0.88 & $\begin{array}{l}\text { Studies with one point increase in mean baseline HAMD } \\
\text { severity result statistically significant in } 0.45 \text { lower effect } \\
\text { size estimates on average. }\end{array}$ \\
\hline
\end{tabular}

\section{WHAT'S NEW}

\begin{tabular}{lll}
\hline Date & Event & Description \\
\hline 8 February 2009 & Amended & Contact details updated \\
\hline
\end{tabular}

\section{H I S T O R Y}

Protocol first published: Issue 3, 1997

Review first published: Issue 4, 1998

\begin{tabular}{lll}
\hline Date & Event & Description \\
\hline 15 July 2008 & $\begin{array}{l}\text { New citation required and conclusions } \\
\text { have changed }\end{array}$ & $\begin{array}{l}\text { 1) The title of the review has been changed from 'St. John's wort } \\
\text { for depression' to 'St. John's wort for major depression'. This re- } \\
\text { flects that inclusion has been now limited to trials in patients suf- } \\
\text { fering from major depression only. }\end{array}$ \\
& $\begin{array}{l}\text { 2) The modification of selection criteria resulted in the exclusion } \\
\text { of } 16 \text { of 37 studies included in the previous version. Eight new tri- } \\
\text { als have been included. The review now covers } 29 \text { trials with } 18\end{array}$ \\
\end{tabular}




\begin{tabular}{lll}
\hline Date Event Description & Den
\end{tabular}

comparisons of a hypericum extract with a placebo and 17 with a standard antidepressant (six three-armed trials).

3) Compared to the previous version our conclusions are now slightly more favourable, as modest effects over placebo have also been shown in several large trials, and as side effects appear to be less frequent compared to both older antidepressants and selective serotonin reuptake inhibitors.

4) The list of authors has been amended.

\begin{tabular}{lll}
\hline 23 May 2008 & Amended & Converted to new review format. \\
\hline 12 December 2007 & $\begin{array}{l}\text { New citation required and conclusions } \\
\text { have changed }\end{array}$ & Substantive amendment \\
\hline
\end{tabular}

\section{CONTRIBUTIONS OFAUTHORS}

Study concept and design: Linde, Berner, Kriston Acquisition of data: Linde, Berner, Kriston

Analysis and interpretation of data: Linde, Berner, Kriston

Drafting and revision of the manuscript: Linde, Berner, Kriston

Statistical expertise: Kriston

Study coordination: Linde

\section{DECLARATIONS OF INTEREST}

Michael Berner has received a grant for research on hypericum in the past and has received fees for speaking on conferences from a manufacturer (Schwabe). Klaus Linde once received reimbursement for travel expenses for speaking on a meeting organised by a manufacturer (Schwabe). Levente Kriston once received reimbursement for travel expenses (Schwabe).

\section{SOURCES OF SUPPORT}

\section{Internal sources}

- Centre for Complementary Medicine Research, Department of Internal Medicine II, Technische Universität München, Germany.

- Department of Psychiatry and Psychotherapy, University of Freiburg, Germany.

\section{External sources}

- No sources of support supplied

\section{N DEX TERMS}

\section{Medical Subject Headings (MeSH)}

${ }^{\star}$ Hypericum; *Phytotherapy; Antidepressive Agents [therapeutic use]; Depressive Disorder [ ${ }^{\star}$ drug therapy]; Plant Extracts [*therapeutic use]; Randomized Controlled Trials as Topic

\section{MeSH check words}

Adult; Humans 